Universidad Nacional de La Plata

Facultad de Humanidades y Ciencias de la Educación Maestría en Ciencias Sociales

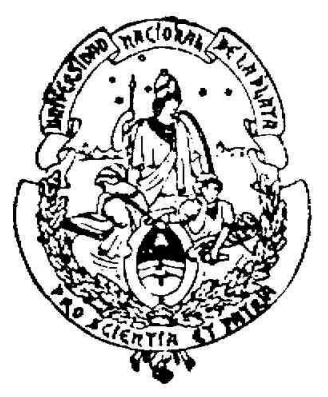

Tesis de Maestría:

\title{
Articulación política en el campo popular argentino
}

\section{Una aproximación desde los discursos de sus organizaciones}

Alumno:

Lic. José Eduardo Moreno

Director:

Dr. Aníbal O. Viguera 
La Plata, juniomayo 2009 


\section{INDICE}

PRIMERA PARTE: PRESENTACIÓN DE LA INVESTIGACIÓN

1. INTRODUCCIÓN

2. ESTADO DE LA CUESTION

Algunas hipótesis sobre la articulación política en el campo popular $\quad 7 \underline{8}$

Los mapas del movimiento piquetero $\quad \underline{109}$

Articulación política en el movimiento piquetero $\quad 1 \underline{54}$

3. PLANTEAMIENTO DEL PROBLEMA

4. ALGUNAS DEFINICIONES CONCEPTUALES $\quad 2 \underline{6} 4$

Sobre lo ideológico $\quad 2 \underline{6} 4$

Articulación y hegemonía $\quad 2 \underline{296}$

Identidad y Diferencia Política $\quad \mathbf{3 2} \theta$

5. CUESTIONES METODOLÓGICAS $33 \underline{\underline{5}}$

Tres dimensiones $\quad 3 \underline{5} 3$

Análisis del discurso $\quad \mathbf{3 7 4}$

Fuentes y técnicas de recolección de datos $\quad 3 \underline{3} 5$

Características de la muestra

SEGUNDA PARTE: ANÁLISIS DE LAS FORMACIONES POLÍTICAS

1. BREVE PRESENTACIÓN DE LAS ORGANIZACIONES

2. AUTODEFINICIÓN IDEOLÓGICA GENERAL

3. CARACTERIZACIÓN DE LAS OTRAS FUERZAS DEL CAMPO POPULAR

4. ENEMIGOS DEL CAMPO POPULAR

5. COYUNTURA POLÍTICA: CARACTERIZACIÓN DEL KIRCHNERISMO

6.

6. CARACTERIZACIÓN DEL ESCENARIO LATINOAMERICANO

7. ESTADO, CLASE Y NACIÓN

8. CRITERIOS DE VERDAD. CIENCIA Y POLÍTICA

TERCERA PARTE: CONCLUSIONES

1. TIPOS DE SUTURA, FIJACIONES DE SENTIDO Y ARTICULACIÓN POLÍTICA

1.1. De cada pueblo un paisano. Lo que deja el análisis de cada organización.

1.2. Palabras Finales $\quad \underline{196}$

BIBLIOGRAFÍA 


\section{PRIMERA PARTE: PRESENTACIÓN DE LA INVESTIGACIÓN}

\section{INTRODUCCIÓN}

Cualquier observador o analista de la política en nuestro país difícilmente pueda dejar de advertir las constantes dificultades que presentan las formaciones políticas del campo popular ${ }^{1}$ a la hora de avanzar en procesos de articulación hacia la constitución de bloques con gravitación en el escenario político. El panorama que observamos nos muestra una amplia variedad de formaciones políticas que suelen identificarse como integrantes del campo popular, pero sin que esta adscripción común -salvo escasas excepciones- lleve a procesos de articulación de alta intensidad. ${ }^{2}$

Esta problemática que atraviesa el universo de las formaciones políticas del campo popular en nuestro país, tuvo su correlato en el devenir de las organizaciones sociopolíticas que constituyeron el llamado movimiento piquetero en la segunda mitad de la década de 1990. Mencionemos someramente algunos datos recabados por una colega de nuestro centro de investigaciones ${ }^{3}$ en los que se puede constatar el proceso de fragmentación que atravesó a este espacio de organizaciones políticas:

Entre 1997 y 1998 se constituía el Movimiento de Trabajadores Desocupados "Teresa Rodríguez" con presencia en varias zonas del conurbano bonaerense (Florencio Varela, Solano y Hurlingham) y también Mar del Plata. Para 2006 se pueden identificar entre seis y nueve organizaciones -depende de los criterios que se utilicen- que, de forma directa o indirecta, estuvieron articuladas en torno a la organización inicial. De la pareja CTA-FTV constituida hacia 1998, encontramos en el 2006 al menos ocho líneas independientes que se originan en torno a la misma matriz.

\footnotetext{
${ }^{1}$ Utilizamos la categoría de campo popular en un sentido estrictamente político y de carácter analítico, no descriptivo. La usamos buscando delimitar nuestro campo de investigación incluyendo en ella a formaciones políticas que se autorreferencian al interior de dicho espacio político-ideológico. Es decir, primero que nada se trata de una categoría política, no refiere a un estrato social o sector socioeconómico. Siguiendo este criterio, tomamos la decisión metodológica de utilizar tal concepto para referirnos a formaciones políticas como el Polo Obrero (PO), la Corriente Clasista y Combativa (CCC), el Movimiento "Teresa Rodríguez" (MTR), el Frente Popular Darío Santillán (FPDS), el Movimiento de Trabajadores Desocupados "Aníbal Verón" (MTD-AV), el Movimiento de Unidad Popular (MUP), el Movimiento Barrios de Pie (MBP) y el Movimiento Patriótico Revolucionario "Quebracho" (MPR-QB). Estas organizaciones participaron de una u otra manera en el ciclo de protesta (Tarrow, 1997) que se desarrolló entre la segunda mitad de la década de 1990 y la asunción de Néstor Kirchner a la presidencia en mayo de 2003 y todas ellas se definen de izquierda, izquierda nacional o nacional populares. Creemos que la categoría de campo popular permite abarcar satisfactoriamente a todas ellas para los fines de este trabajo.

${ }^{2}$ El concepto de articulación política ha sido usado en sentidos diversos, en algunas ocasiones en referencia a tipos muy específicos de relación entre grupos sociales u organizaciones. En nuestro caso utilizaremos el concepto en un sentido amplio, abarcando las diferentes modalidades que adquieren las relaciones entre las organizaciones cuando se orientan en un sentido de acercamiento. Por tal motivo hablaremos de articulaciones con distintos niveles de intensidad, niveles que a la vez no se reducen a distinciones meramente cuantitativas -es difícil imaginar esto cuando se trata de fenómenos de este tipo-, sino que implican diferencias de tipo cualitativas. Más adelante desarrollaremos esta cuestión.

${ }^{3}$ Los datos que se mencionan fueron recabados por la Lic. Lucrecia Gusmerotti, integrante del Centro de Investigaciones Socio-Históricas, en el marco del proyecto Prácticas de movilización política, acción colectiva de protesta y movimientos sociales en la Argentina.
} 
De las cinco organizaciones piqueteras vinculadas a partidos de izquierda que había en 2002, pasaron a ser alrededor de diez, luego de diversos desprendimientos y fracturas.

Es decir, el recorrido atravesado por el conjunto de organizaciones del movimiento piquetero desde la segunda mitad de la década de 1990 hasta nuestros días presenta un vertiginoso relato sobre las características que adoptan los reordenamientos, escisiones y agrupamientos entre las diferentes fuerzas que componen el espacio. Por su complejidad, velocidad y representatividad, el estudio de las organizaciones del movimiento piquetero ${ }^{4}$ será nuestro punto de partida para ingresar a la problemática, más amplia, sobre la tensión articulación/fragmentación política del campo popular que comenzaremos a desarrollar en este trabajo.

Comenzaremos por algunas preguntas que por ser simples no dejan de plantear cuestiones relevantes: ¿Por qué el campo popular aparece tan fragmentado? Enseguida podríamos repreguntarnos: ¿Por qué no? ¿Por qué habría de ser de otra manera? Sencillamente uno podría decir que se trata de una gran cantidad de organizaciones que poseen orígenes muy diversos y claras diferencias políticas e ideológicas y que al interior de las mismas se van desarrollando diferencias del mismo tipo que provocan escisiones y desprendimientos. De esta manera, la fragmentación que se observa aparece rápidamente explicada.

Sin caer en semejante simplificación, hemos constatado que muchas de las investigaciones que abordan este tema resuelven el problema en esta dirección: entre el universo de formaciones políticas del campo popular se evidencian diferentes orígenes y recorridos, diferentes orientaciones ideológicas, diferentes estrategias políticas; por todo esto, la fragmentación -o la falta de articulación- resulta inevitable. Frente a esta perspectiva, y sin ánimos de querer resolver el tema de inmediato, podemos señalar dos cuestiones -fuertemente relacionadas- que nos abren nuevos interrogantes y hacen insuficientes algunas de las respuestas más comunes sobre el tema.

En primer lugar, podemos mencionar una cuestión vinculada con las diferentes experiencias políticas de órbita de la izquierda que han logrado, en distintos momentos

\footnotetext{
${ }^{4}$ Vale aclarar que no todas las organizaciones que estudiamos en este trabajo son estrictamente lo que se conoce como organizaciones piqueteras. Tanto el FPDS, el MPR-QB, como el MUP, constituyen organizaciones con múltiples dimensiones de trabajo que incluyen desde centros culturales hasta agrupaciones universitarias, pasando por un variado de arco de modalidades de militancia. Sin embargo, más allá de las diversas prácticas militantes, cada una de estas organizaciones ha tenido un papel destacado en el llamado movimiento piquetero; llevando a la práctica política con los trabajadores desocupados, a adquirir una gran centralidad en el esquema de cada una de ellas.

El resto de las organizaciones, la CCC, el PO, el MBP, el MTR y el MTD-AV, sí pueden considerarse organizaciones piqueteras, siendo las tres primeras -y más allá de las diferencias que hubiera en cada caso- una suerte de "brazo social-territorial" de organizaciones políticas más amplias (Partido Comunista Revolucionario, Partido Obrero y Libres del Sur, respectivamente), mientras que las dos últimas se circunscriben a tal dimensión política sin referir a organizaciones más amplias.
} 
y lugares, un desarrollo político relevante. En este sentido resulta muy dificultoso negar que todos los procesos de construcción política incluyen diversos niveles de articulación entre distintos actores, más allá de sus diferencias ideológicas. La articulación política puede adquirir múltiples modalidades y formas, puede ser de alta o de baja intensidad, pero parece estar presente en cualquier proceso político con aspiraciones de disputar el poder en una sociedad. ${ }^{5}$ En este sentido nos podemos preguntar ¿cómo podemos explicar las distintas experiencias históricas de unidad y articulación política entre actores con diferencias ideológicas y tradiciones políticas diversas si utilizamos este mismo argumento para sostener lo contrario? Esto conduce a preguntarnos: ¿En qué consisten tales diferencias y de qué manera inciden en las posibilidades de desarrollar procesos de articulación política?

En segundo lugar, y reafirmando el punto recién mencionado, encontramos en las declaraciones y discursos de los referentes de las distintas formaciones políticas en unos más que en otros- claras alusiones a la necesidad y la importancia de avanzar en la articulación y la unidad del campo popular "más allá de las diferencias". Hay un consenso generalizado en identificar a la fragmentación política del campo popular como la tarea a resolver, como el principal problema que atenta contra las posibilidades de éxito político entre las organizaciones de ese espacio. El interrogante anterior se repite con la misma pertinencia: ¿Cuáles son los factores que operan para que no se materialicen las intenciones de unidad y articulación?

Recapitulando: No planteamos que necesariamente un determinado conjunto de formaciones políticas deban confluir -por determinados elementos en común- hacia la articulación y la unidad política. Pero más allá de esto podemos decir que, tanto el acervo histórico como las intenciones manifestadas por los referentes de las formaciones políticas, sugieren la necesidad de avanzar en procesos de articulación política que en los últimos años no lograron materializarse.

Es en medio de este panorama que se inscribe esta investigación con la pretensión de dar respuesta a algunos de los interrogantes de una problemática que se presenta sumamente compleja. Cabe señalar que nuestro trabajo no buscará ser una investigación exhaustiva de la historia del movimiento piquetero. Tampoco apuntamos a la construcción de una tipología sobre las distintas instancias de articulación que hayan podido materializarse en dicho movimiento. Del mismo modo, no pretendemos abarcar ni analizar todos los factores que operan en la articulación política. Sabemos que factores como el personalismo, las disputas de poder, liderazgos y hasta problemas (que podríamos llamar) personales, operan y pueden

\footnotetext{
${ }^{5}$ Para respaldar esta idea resulta ilustrativo el tratamiento que realiza Fernando Mires sobre distintos procesos revolucionarios en América Latina en su libro La rebelión permanente. La revoluciones sociales en América Latina, (Mires, 1988).
} 
tener gran relevancia en la explicación de las modalidades que adquiere la articulación política entre las organizaciones.

Sin desconocer la importancia de estas cuestiones, nuestro abordaje se centrará en los elementos político-ideológicos ${ }^{6}$ presentes en los discursos que configuran las identidades políticas de las organizaciones -la constitución del nosotros y del ellos- y sus implicancias respecto al tema de la articulación. Es decir, indagaremos en los discursos identitarios ${ }^{7}$ en busca de aquellos elementos políticoideológicos que pudieran incidir en las modalidades que adquiere la articulación política entre las organizaciones del campo popular.

Desde nuestra perspectiva consideramos a los discursos identitarios compuestos por un conjunto de elementos político-ideológicos que incluyen desde grandes visiones y formas de aprehensión del mundo social hasta definiciones que remiten a la forma específica que debe adoptar la disputa política. En este sentido, identificamos una serie de tópicos o dimensiones en torno de los cuales se establecen los diferentes posicionamientos que van configurando la identidad política de cada organización. Entre los tópicos o dimensiones que nos resultan relevantes podemos mencionar las posiciones respecto a: 1) el fin último o "punto de llegada"; 2) el modo en que se debe ejecutar la transformación (concepción del Estado, revolución vs. reforma, etc); 3) el sujeto político (relación clase-partido); 4) la "cuestión nacional" ("soberanía política e independencia económica"); 5) la pretensión de representatividad de la organización; 6) las formas de la disputa política (insurreccionalismo, parlamentarismo, etc); 7) el peso de la coyuntura política; 8) y los principios organizativos (autonomía, democracia de base, etc).

Observaremos estos elementos a partir de la comparación de las definiciones de las distintas organizaciones en relación a una serie de ejes comparativos que constituirán los diferentes capítulos de este trabajo. Si bien nos interesa cotejar qué posición concreta toma cada organización en relación a estas dimensiones socialismo, revolución, insurreccionalismo, etc.--; haremos especial hincapié en el modo en que se presentan tales posicionamientos, esto es, en la fijación de sentido que adquiere cada uno de estos elementos $y$, por tanto, en las posibilidades que se abren para favorecer consensos y entendimientos entre posturas diferentes.

\footnotetext{
${ }^{6}$ Decimos "político-ideológicos" porque incluimos tanto a aquellas grandes concepciones y visiones sobre lo social (más adelante daremos una definición más precisa de lo ideológico) como a los elementos que, derivados de aquellas grandes concepciones, remiten a definiciones concretas sobre la táctica y la estrategia de la práctica política: relación clase-partido, revolución o reforma, etc.

7 A modo de definición preliminar, podemos señalar que entendemos como discursos identitarios al conjunto de definiciones y posicionamientos que una organización establece mediante actos simbólicos lingüísticos o no lingüísticos- y que configuran su identidad en cuanto a formación política. Más adelante nos detendremos en los conceptos de identidad política y formación política apelando a algunas definiciones de Gerardo Aboy Carlés.
} 


\section{ESTADO DE LA CUESTIÓN}

En busca de ordenar y sintetizar el vasto acervo bibliográfico relacionado con nuestra problemática, podemos pensar en dos grandes campos de trabajo que se vinculan directamente con el nuestro: por un lado aquellos trabajos que reflexionan sobre el tema de la articulación política del campo popular en nuestro país; y por el otro, aquellos que se centran en el análisis de las organizaciones de desocupados que componen el llamado movimiento piquetero. Del mismo modo, a partir de la combinación de los grupos que surgen de esta distinción primaria, podemos conformar, a su vez, tres categorías: los que abordan el problema de la articulación política sin hacer referencia específica al universo de las organizaciones de desocupados; los trabajos que se centran en la problemática de las organizaciones de desocupados sin hacer mención directa al tema de articulación política; y, finalmente, los que coinciden en trabajar ambos tópicos.

\section{Algunas hipótesis sobre la articulación política en el campo popular}

En líneas generales, hay un importante consenso en considerar al llamado campo popular desde dos rasgos sobresalientes: su fragmentación y su debilidad. Más aún, ambos rasgos estarían fuertemente interconectados y se potenciarían el uno al otro. Las causas que se invocan para explicar tal estado de cosas suelen recorrer, como tópico ineludible, el peso del peronismo en la reconfiguración del escenario político nacional (Borón 2000, Di Tella 2003 y 2004).

Consultado sobre las causas de la fragmentación política del campo popular ${ }^{8}$, Atilio Borón destaca que "el peso que el peronismo ha tenido en la vida social y política de la Argentina capturó lo que tendría que haber sido la base de masas de una organización política de izquierda". Y luego agrega que no es casual, "que este fenómeno de dispersión de la izquierda se dé tan nítidamente en la Argentina, donde existe el movimiento populista más radical e importante de América latina, que produjo la mayor redistribución del ingreso hasta la Revolución Cubana".(La Nación, 25/11/07) A la vez destaca la responsabilidad por parte de la izquierda de no haber interpretado adecuadamente al peronismo -como así también al yirigoyenismo- lo que la condenó a una situación de cuasi marginalidad política (Borón, 2000).

En el mismo sentido Torcuato Di Tella señala que "el Justicialismo renovado actual ocupa el lugar de una izquierda moderada, con capacidad de cooptar también a unos cuantos grupos de mentalidad fundamentalista". Luego añade que "la característica movimientista del peronismo le permite ser más englobador que la

\footnotetext{
${ }^{8}$ En rigor, las respuestas son sobre la fragmentación de la "izquierda", pero coincide con la definición de nuestro objeto de investigación y creemos válido homologarlo con la categoría que aquí decidimos escoger que es la de "campo popular". Lo mismo para el caso de la intervención de Di Tella.
} 
izquierda moderada europea, chilena o uruguaya" (La Nación, 25/11/07). En algunos de sus trabajos (Di Tella 2003 y 2004), el autor argumenta que existe una suerte de "tendencia universal" que lleva a los sistemas políticos hacia formatos bipolares en los que interactúan dos grandes bloques políticos de izquierda -o centro izquierda- y de derecha -o centro derecha. El caso argentino no sería una excepción y estaría marchando hacia dicha forma, pero la complejidad del peronismo dificultaría retrasaría- la conformación de estos bloques desdibujando el rol que le correspondería a las formaciones del campo popular.

De esta manera, el peronismo aparece como una fuerza política que le disputa a las formaciones políticas del campo popular sus bases de apoyo y algunas de sus banderas como no sucedería con movimientos populistas en otros países. Esa tensión que se genera y la competencia resultante estarían explicando la debilidad de las formaciones del campo popular y su consecuente fragmentación. El peronismo actuaría así como una suerte de agujero negro que absorbe y debilita las formaciones políticas del campo popular y las conduce a un proceso de fragmentación. La debilidad y la fragmentación serían dos caras de la misma moneda.

En un plano similar se ubica Alfredo Pucciarelli (2002) quien también destaca un escenario de marcada debilidad para el desarrollo de las formaciones del campo popular. Sin embargo, a diferencia de los otros planteos, no hay una perspectiva histórica que le otorgue al peronismo centralidad explicativa, más bien se destaca el escenario de crisis y marginalidad -económica e institucional- que se da en el contexto de la ola neoliberal de los años recientes. Es este escenario el que rompe los viejos lazos sociales sobre los que se estructuraban las anteriores formas de acción, dando lugar a nuevas experiencias más bien "voluntarias", sin las "sólidas raíces materiales" de sus antecesoras. En definitiva, se trata de un contexto en el cual el campo popular aparece fuertemente debilitado, con serias dificultades de articular, tanto entre las distintas organizaciones, como entre los distintos niveles de construcción -partidos y movimientos sociales- y sus tiempos y lógicas.

Es en esta última problemática que se centra la preocupación de Alejandra Parra (2008) cuando señala que la centralidad del problema de la articulación remite tanto a la lógica fragmentaria y divisionista del capitalismo, como a la "complejización y fragmentación de las actuales formas de lucha" (2008:29), las que si bien pueden entenderse por la positiva, como manifestaciones de diversidad y multiplicidad, también incluyen implicancias respecto a la articulación política. La problemática de la articulación se plantea aquí en un debate que contrasta los diferentes modelos teóricos de abordaje, no en relación a las dificultades derivadas de las diferencias 
político-ideológicas, sino en la dialéctica entre lo particular y lo general, entre las especificidades de cada lucha y las dificultades de que estas constituyan un colectivo.

Respecto a este último planteo, las dificultades de la articulación aparecen originadas tanto en las macro tendencias del capitalismo, como en la propia complejización de las formas de lucha ${ }^{9}$. En este sentido la preocupación respecto de la articulación se enfoca en la relación entre lo situacional y lo general, entre las problemáticas específicas y la posibilidad de desarrollar un sentido unificador de tales luchas. Desde esta perspectiva, se desatiende la fragmentación entre las organizaciones pares (partidos, organizaciones piqueteras, etc.) que se plantean en términos de diferencias político-ideológicas. Son estas las que más nos interesan aquí.

En relación a las perspectivas observadas en primer lugar, las dificultades que aparecen en torno a la articulación política del campo popular argentino se identifican de modo general con la situación de debilidad de las formaciones políticas que lo componen. Esta debilidad aparece explicada tanto por la centralidad que adquirió el peronismo en el mapa político nacional, como por el deterioro socio-económico e institucional-político derivado de los años de la oleada neoliberal. Lo que parece no estar explicado con claridad es el modo en que se vinculan la debilidad con la fragmentación, en tanto se presentan como si una supusiera la otra. Quizás no resulta complejo comprender por qué la fragmentación deviene en debilidad, pero no sucede lo mismo cuando la relación se piensa de modo inverso.

\section{Los mapas del movimiento piquetero}

Como señalábamos más arriba, lo que sucede en el movimiento piquetero en alrededor de diez años, permite observar una importante cantidad y variedad de elementos que nos parecen de gran relevancia para adentrarnos en el estudio de la temática propuesta por esta investigación. Las aproximaciones y abordajes han variado tanto en función de los aspectos privilegiados por los intereses específicos de cada investigador, como por sus pretensiones abarcativas.

Así encontramos una serie de trabajos que abordaran el tema desde el análisis de la protesta, la acción política (y visible) de las organizaciones: el piquete o corte ruta. Al interior de este conjunto aparecen toda una serie de trabajos con características diferentes: algunos indagaran el fenómeno discutiendo sobre las causas estructurales de su aparición (Tenti Fanfani, 2000; Scribano, 1999), sobre las causas concretas de casos específicos (Favaro y otros, 1997; Gómez/Kindgard, 1998; Cotarelo, 2002; Colectivo Situaciones, 2002), o sobre la articulación de las macro tendencias con las especifidades locales (Auyero, 2000 y 2002); otros ensayaran

\footnotetext{
${ }^{9}$ No está claro en el planteo el grado de vinculación que pudiera haber entre ambos procesos.
} 
descripciones del ciclo de protesta en su totalidad ${ }^{10}$, desde aproximaciones que privilegian el recorrido histórico de las formas de protesta (Laufer/Spiguel, 1999; Gómez, 2007), su performance cuantitativa según su distribución espacio-temporal y sus principales demandas (Iñigo Carrera/Cotarelo, 1998; Cotarelo, 2000; Klachko, 2005), su potencial transformador (Dinerstein, 2001), su tratamiento desde el Estado (CELS, 2003), etc. La lista podría extenderse mucho más.

Otro grupo de trabajos que podemos distinguir es aquel que ya no aborda el tema desde la acción política disruptiva sino desde el sujeto político: ya no es el piquete, sino la organización de desocupados. El estudio de las organizaciones también es tratado de múltiples maneras, atendiendo a las diversas variables que resultan relevantes según los distintos intereses. Así aparecen una gran cantidad de trabajos que, ya sea mediante abordajes que buscan una comprensión global del tema (Svampa-Pereyra, 2003; Almeyra, 2004, Delamata, 2004), o aquellos cuyos aportes hacen foco en dimensiones específicas -(la llamada "identidad piquetera" (Lenguita, 2001; Delfini y Picchetti, 2004; Masetti, 2007), las causas y consecuencias de la inscripción territorial (Merklen, 2005), las trayectorias obrero-sindicales de sus miembros (Maceira y Spaltenberg, 2001), sus vinculaciones con el Estado (Petras y Veltmeyer, 2005; Maneiro, 2007) o diferentes estudios de caso que exploran en profundidad la trama de relaciones constitutivas y sus implicancias en la conformación de los principales rasgos de cada organización (Forni, 2002; Delamata y Armesto, 2005; Colectivo Situaciones, 2001; Bidaseca, 2004; Ferraudi Curto, 2006), etc).- logran dar cuenta del amplio y variado conjunto de elementos que resultan centrales para una caracterización del llamado movimiento piquetero.

Al interior de este vasto conjunto de aportes quizás resulte útil para los fines de nuestro trabajo la distinción que proponen D’Amico y Pinedo (2008) cuando diferencian dos tipos de enfoques en relación al abordaje de las organizaciones piqueteras: por un lado aquellos trabajos que abordan a las organizaciones en tanto "actores colectivos", "como sujeto que irrumpe en la escena política pública, cuya característica principal está dada por las demandas que los constituyen como tal" (2008:2); mientras que por otro lado aparecen los abordajes, de corte más etnográfico, que se centran en la exploración de la "trama de relaciones que constituyen las organizaciones" (2008:2). Así, mientras que en el primer grupo la organización funciona como la unidad mínima de análisis, en el segundo lo que se busca, justamente, es romper con tal unidad desentrañando los diversos sentidos y tramas que constituyen su diversidad y complejidad interna.

\footnotetext{
${ }^{10}$ Hay un consenso amplio en identificar a los sucesos de protesta de diciembre de 1993 en la provincia de Santiago del Estero -en lo que se dio en llamar el "Santiagueñazo"-, como el punto de partida del ciclo de protestas que tendrá al llamado movimiento piquetero como principal protagonista.
} 
Por las características de nuestra investigación, nos interesan aquellos trabajos que se inscriben en el primero de estos grupos y que prestan especial atención a los rasgos político-ideológicos que definen a cada organización como actor político particular. Nos detendremos brevemente en dos trabajos que tienen en cuenta estos elementos y presentan distintos agrupamientos y categorizaciones que, sin abordarla específicamente, se vinculan con la temática de la articulación política.

En Los barrios desbordados, Gabriela Delamata (2004) realiza una clasificación de las organizaciones de desocupados del conurbano bonaerense a partir del criterio del origen que cada organización presenta. De esta manera identifica tres grandes grupos: En primer lugar, están aquellas "organizaciones previamente constituidas que buscan ampliar su esfera de representación y en el giro transforman el sentido de su acción" (Delamata, 2004:32). En este grupo se van a incluir a las dos grandes organizaciones del partido de La Matanza, el "eje matancero", la Federación Tierra y Vivienda (FTV) y la Corriente Clasista y Combativa (CCC). En este caso tenemos dos organizaciones que comparten un sello de origen, y que a la vez, en el accionar político, desarrollaron significativas instancias de articulación.

El segundo grupo de organizaciones es el de aquellas "forjadas alrededor de una militancia política o social que constituye el punto de partida para la organización y el núcleo de la opción política de cambio social" (Delamata, 2004:33). Se incluyen aquí organizaciones tales como el MTD de Solano, el MTD Resistir y Vencer, la Coordinadora de Trabajadores Desocupados (CTD) "Aníbal Verón” y el Movimiento Teresa Rodríguez (MTR). Al igual que en el caso anterior, el agrupamiento coincide con procesos de articulación que diferentes momentos vincularon a varias de estas organizaciones.

Finalmente, el tercer grupo es aquel en el se ubican las organizaciones creadas por un partido político nacional a fin de insertar al colectivo de desocupados como un sector más dentro de la organización política" (Delamata, 2004:33). Aquí solo se menciona al Polo Obrero, como el "brazo piquetero" del Partido Obrero, pero podríamos pensar en otros agrupamientos tales como el Movimiento Territorial de Liberación (MTL) ligado al Partido Comunista (PC) o al Movimiento Sin Trabajo (MST) "Teresa Vive" -vinculado al Movimiento Socialista de los Trabajadores-, por nombrar algunos.

Como se desprende del propio criterio de clasificación, los grupos construidos en este esquema no buscan orientarnos en el tema de esta investigación -no es su propósito-, sin embargo no podemos dejar de ver cierta concordancia entre esta taxonomía y la que resulta de la proximidad política que experimentaron la mayoría de estas organizaciones al interior de cada subgrupo. Es decir, las categorías construidas 
por la autora a partir del origen de las organizaciones coinciden, en cierto punto, en lo que respecta a los lineamientos políticos que las organizaciones adoptaron. El origen específico de cada formación política obedece a determinados elementos, entre los cuales encontraremos concepciones u orientaciones ideológicas comunes. En nuestro trabajo intentaremos explorar qué características adopta esta dimensión ideológica y el modo en que opera en los posicionamientos o dimensiones de la acción.

Maristella Svampa y Sebastián Pereyra han abordado el estudio del movimiento piquetero en diversos trabajos (2003; 2005; Svampa, 2005; 2006a y 2006b; Pereyra, 2002; entre otros) en los que la dimensión política de los distintos agrupamientos socio-políticos adquiere gran relevancia. En su libro Entre la ruta y el barrio (2003), es sin dudas donde los autores hacen su caracterización más detallada sobre la cuestión.

Cualquier clasificación que se elabora para ordenar un universo tan complejo y multidimensional como este, resulta dificultosa. Respecto al trabajo del que estamos hablando, las dificultades surgen de inmediato y son destacadas por los propios autores. Buscando caracterizar la configuración (política) del espacio piquetero de acuerdo a sus grupos $y$ alineamientos sugieren un primer criterio que agrupa las organizaciones "según estos se organicen en torno del sindicato, en torno del partido político o como grupos autónomos." (2003:54). Inmediatamente dan cuenta de las ambigüedades que resultan de esta opción: ¿Dónde ubicar a la CCC, atravesada tanto por su experiencia sindical como por su pertenencia al PCR? ¿Qué sentido tiene agrupar a organizaciones tan distintas como el MTR y el MIJP por el simple hecho de ser grupos autónomos?

Descartado el eje organizativo como criterio de diferenciación, optan por incorporar la orientación general de la acción, (política, sindical y territorial) junto con los diferentes modelos de intervención y militancia:
Así, para dar cuenta de la dimensión específicamente política de la acción colectiva, abordaremos entonces el modo en que el cruce entre las tres dimensiones de la acción (lo sindical, lo territorial y lo político) ha venido definiendo los diferentes alineamientos políticos que surcan el espacio piquetero.(2003:55)

De esta manera, los autores establecen un primer corte en función de la interacción de estas dimensiones de la acción, que recorren el universo del movimiento piquetero. Siguiendo este criterio de distinción, los clivajes políticos estarían definiendo dos alineamientos principales y un tercero de menor relevancia o protagonismo"11: (a) el primero ("la línea sindical"), "estaría constituido por una línea

\footnotetext{
${ }^{11}$ Como veremos más adelante, el tercer grupo va adquirir mayor relevancia y protagonismo en diferentes momentos del período y serán reconsiderados en otros trabajos de estos autores con otra valoración y relevancia (Svampa, 2005; 2006a; 2006b).
} 
política más "institucionalizada", reunida alrededor de las corrientes y centrales sindicales no oficialistas"; (b) el segundo, ("la política radical”), plantea "una línea (...) ciertamente menos institucionalizada (...) agrupada en torno de partidos políticos y grupos autónomos de izquierda"; y (c) la tercera ("línea territorial"), de carácter minoritario y "encarnada por aquellos grupos que reivindican el "no alineamiento", y reclaman una manera de hacer política más centrada en el trabajo local y microsocial." (2003:55).

Dentro de este enfoque, resulta central la postura que adoptan las organizaciones respecto al sistema político institucional y el sentido que le adjudican a la práctica política. Desde esta perspectiva, la línea sindical (FTV-CTA y CCC-PCR) aparece con una actitud condescendiente y negociadora respecto del sistema político institucional, nutrida de una fuerte matriz nacional-popular según la cual se busca reeditar un modelo de sociedad industrial, con un Estado benefactor y pleno empleo. Su accionar político se orienta en esa dirección y la política aparece entendida como la búsqueda de acumulación de poder frente al resto de las fuerzas que se debaten en el ámbito institucional.

La línea política radical está compuesta por organizaciones de desocupados creadas al amparo de partidos políticos de izquierda y grupos políticos autónomos. Al interior del primer grupo se distinguen a la vez tres subgrupos: los "trotskistas" (PO, MST y FTC), los "no trotskistas"12 (MTL y CUBA) y los "nacionalistas de izquierda" (CTD y Barrios de Pie). Por el lado de las organizaciones creadas al amparo de grupos políticos autónomos se menciona al MTR y al MIJP. La característica sobresaliente que distingue este agrupamiento es el seguimiento de una línea política más disruptiva y menos institucional que la que propone la línea sindical. Plantea un rompimiento con los principales elementos del sistema político institucional, disminuyendo casi totalmente cualquier posibilidad reformista, en el sentido de cambios graduales inscriptos al interior de las instituciones políticas existentes. La dimensión de la acción se direcciona hacia la acumulación y masificación del poder que permita modificar sustancialmente las bases del sistema mediante la toma del poder del Estado. Las fuerzas que integran el sistema político, son vistas cómo parte de un todo que debe ser combatido. Desde esta perspectiva, la línea sindical, es vista como claudicante y negociadora de un proyecto político que va más allá de ciertas reformas progresistas.

\footnotetext{
${ }^{12}$ Es llamativo que el segundo subgrupo no aparezca definido en términos positivos, sino como "lo que no son", lo que hace de la categorización un tanto incompleta y difusa. Creemos que esto es así ya que para definir en términos negativos habría que ampliar el espectro de "lo que no son": "no trotskistas", "no nacional-populares", "no izquierda nacional", etc.
} 
Por último, la línea territorial (MTD-AV, UTD y MTD La Juanita), descree tanto de las soluciones populistas como de estrategias revolucionarias enmarcadas en la matriz marxista-leninista. Este alineamiento orienta su acción al desarrollo de nuevas formas de sociabilidad y espacios de poder paralelos al sistema dominante. Por esto, aparecen fuertemente disminuidas tanto la salida reformista como la toma del poder del Estado y se refuerzan las acciones que buscan fortalecer espacios de microsociabilidad en donde primen mecanismos democráticos y horizontales y prácticas que reconstruyan lazos sociales solidarios.

Esta categorización que prioriza las orientaciones de la acción resulta convergente con los propósitos de este trabajo, sin embargo nos parece que las dimensiones de la acción aparecen más como un punto de llegada que de partida. Es decir, las distintas posturas que permiten agrupar a las organizaciones en los tres alineamientos mencionados, nos plantea diversos interrogantes de relevancia: ¿Qué es lo que opera para que las organizaciones se ubiquen en un alineamiento institucional, disruptivo-insurreccional o territorial-local? ¿A qué obedecen estos alineamientos? La respuesta a estas preguntas, los autores la buscarán en las orientaciones ideológicas, dimensión central de nuestro análisis, que veremos en el siguiente apartado.

\section{Articulación política en el movimiento piquetero}

Finalmente llegamos al tercero de los grupos que mencionábamos al principio, es decir, aquel que se refiere explícitamente a la temática de la articulación política al interior del movimiento piquetero. Nos detendremos en tres planteos que nos parecen relevantes para ir perfilándonos al desarrollo de nuestro análisis. En todos los casos se parte del mismo diagnóstico: el movimiento piquetero, al igual que el resto del campo popular, está atravesado por una fuerte fragmentación política.

Aldo Casas (2004) -y luego lo retomará, de manera literal, Sergio Zeta (2005)señala que la fragmentación que se observa en el movimiento piquetero
"guarda relación con las tensiones que genera actuar como mediadores entre el Estado y los potenciales "beneficiarios" de los Planes sociales a los que se busca organizar, con la inexistencia o severos límites a la democracia de base en las instancias de coordinación (...) $y$, más en general, a la inexistencia de una orientación general efectiva para la confluencia con el conjunto de los trabajadores y sectores en lucha." (Casas, 2005) (las negritas son nuestras).

Es decir, se señalan como elementos vinculados a la fragmentación política la condición específica de ser mediadores entre el Estado y los propios militantes, las falencias en torno a las prácticas democráticas al interior de las organizaciones, y por último, la ausencia de un punto gravitacional que haga de espacio de confluencia para 
el conjunto de las fuerzas. Más adelante Zeta (2005) agrega, como factores que agudizan el problema de la fragmentación, la "adhesión incondicional" de organizaciones como la FTV y MBP al gobierno de Néstor Kirchner, la "feroz campaña mediática" respecto a los "que continuaron la lucha", y finalmente, el "hegemonismo" que demuestran organizaciones como el PO y el MIJD en sus relación con e resto de las organizaciones del movimiento piquetero.

En líneas generales, las hipótesis que esbozan los autores resultan interesantes y atendibles, aunque nos parece que se trata de planteos que, hasta donde son presentados, se mantienen en un plano meramente especulativo y, a la vez, derivan en nuevos interrogantes que quedan sin respuesta. Por un lado hay algunas de las relaciones que no resultan del todo claras y merecen ser explicadas con mayor precisión: ¿Por qué la mediación entre Estado y militantes deriva en fragmentación? o ¿Por qué lo hacen las limitaciones en la democracia de base? En segundo lugar, otra de las líneas argumentativas resalta a los factores externos, vinculados a los sectores dominantes -cooptación del gobierno y el rol de los grandes medios- que operan en la profundización de las diferencias que mantienen las organizaciones. En tercer orden, se destacan comportamientos de algunas organizaciones -"adhesiones incondicionales" al gobierno, hegemonismo- que promueven las tendencias hacia la fragmentación política. Finalmente queda la ausencia de una orientación general efectiva para la confluencia, es decir una instancia de acuerdos mínimos que permita avanzar en procesos de articulación política.

Los primeros elementos que se mencionan obedecen a la especificidad de las organizaciones de desocupados, es decir, no permiten su extrapolación al campo popular no piquetero. Los factores externos forman parte de las constantes que prefiguran el escenario en el que deben moverse las organizaciones. Son los mencionados comportamientos de las organizaciones y las dificultades para promover una instancia superior que promueva consenso, los elementos que se aproximan al modo en que pretendemos encarar el tema desde aquí. Las orientaciones ideológicas terminan estando en el centro del diagnóstico de los autores y en esa dirección se moverán otros. En la profundización del análisis de los rasgos que definen política e ideológicamente a las organizaciones intentaremos abordar la comprensión de tales elementos.

James Petras y Henry Veltmeyer (2005) analizan esta cuestión en un trabajo que se centra en la realidad política nacional de los últimos años a la luz de la dinámica desarrollada por los diferentes movimientos sociales denominados como 
organizaciones orientadas al cambio social (OOCS). El trabajo de Petras/Veltmeyer desarrolla en su capítulo 2 (De la rebelión popular al "capitalismo normal" en Argentina) un análisis político sobre las características de la gestión de gobierno del presidente Kirchner y su impacto en las experiencias de construcción política de las organizaciones de desocupados, el movimiento de fábricas recuperadas y el movimiento asambleario. Más allá de algunas imprecisiones a la hora de describir el universo de las organizaciones de desocupados ${ }^{13}$, el trabajo reconstruye el período pos 19 y 20 con algunos análisis interesantes.

El universo piquetero aparece para estos autores dividido en tres grandes grupos, dependiendo de la postura que cada una de las organizaciones adopta respecto al gobierno de Néstor Kirchner. En una primera clasificación los autores distinguen entre las organizaciones que apoyan al presidente, las que ejercen un "apoyo crítico" y las que se oponen "sin matices". A partir aquí, la descripción de las organizaciones se torna un poco confusa.

En primer lugar señalan que "los sectores pro-Kirchner de los MTD"14 (ambas variantes), están acompañadas "por las tres mayores confederaciones sindicales (la CTA, la CGT y los trabajadores del transporte público)." ${ }^{15}$ (2005:74) Se incluyen aquí los sectores manifiestamente oficialistas, como los que declaman un "apoyo crítico". Siguiendo la descripción, aparece el sector de los anti-Kirchner, que también está dividido en varias coaliciones y sectores, constituyendo un amplio abanico que fluctúa constantemente siguiendo los avatares de la coyuntura política. De este modo se señala, por ejemplo, la coalición -estrictamente- opositora compuesta por el Polo Obrero, CUBA, un sector del MTR y el MTL separada de otros grupos también opositores como la CCC o el sector del MTR encabezado por Roberto Martino, pero que destacan el cambio de escenario, de las estructura de oportunidades políticas. Por último, el capítulo pasa a comparar con un poco más de detalle las posturas de dos

\footnotetext{
${ }^{13}$ Nos referimos a algunos errores en las siglas de las organizaciones y algunas generalizaciones que atribuyen, erróneamente, actitudes políticas de algunos grupos que no son tales. A medida que analicemos el trabajo, serán señalados algunos de estos errores.

${ }^{14}$ Los autores utilizan la sigla MTD (Movimiento de Trabajadores de Desocupados) refiriéndose al conjunto de las organizaciones piqueteras y no a las organizaciones particulares que usan ese nombre.

${ }^{15}$ Equivocadamente los autores se refieren a los trabajadores del transporte público constituyendo una de las tres confederaciones sindicales del país. Por otro lado, la CTA nunca manifestó un apoyo explícito al gobierno de Kirchner, y existen en su interior sectores fuertemente críticos del kirchnerismo. Sí podría decirse aquello sobre la FTV, pero está lejos de representar la totalidad de los sectores que integran la CTA. Para un tratamiento de esta cuestión ver Armelino (2004).
} 
importantes organizaciones (MTD Aníbal Verón ${ }^{16}$ y MTR-Martino ${ }^{17}$ ) tratando de retratar como, a partir de la evaluación que se elabora respecto del gobierno de Kirchner, se va acentuando la división del campo popular a partir de las diferencias que resultan de los diagnósticos de cada una de las organizaciones.

La categorización recién expuesta no es otra cosa que la resultante de una tendencia hacia la desunión que ha atravesado al campo popular en su conjunto. Dicha taxonomía funciona más como punto de llegada que de partida. Nos faltan aquí los elementos explicativos que hacen que las diferentes organizaciones evalúen y actúen de forma diferente provocando la mentada desarticulación del universo piquetero.

Intentando responder estos interrogantes los autores mencionan algunos elementos explicativos interesantes, aunque quizás no son desarrollados en profundidad ni se señala el modo específico en que operan. El tema que aparece con más fuerza en este sentido es el de la cuestión de la territorialidad, de lo local-barrial, como tendencia predominante entre las organizaciones de desocupados que tiene un fuerte impacto en la fragmentación política. Para los autores, la debilidad estratégica del movimiento piquetero radicó en "la ausencia de una dirigencia nacional capaz de unificar las diversas fuerzas detrás de un programa coherente para tomar el poder estatal." (2005:70) Más adelante señalan que el concepto de autonomía de los viejos partidos sirvió de excusa para justificar el ascenso de líderes locales en cada barrio, que terminaron boicoteando el esfuerzo de que las distintas confluyeran en una fuerza nacional. Esto llevó a circunscribir las luchas de las organizaciones desde objetivos políticos generales a planes sociales para el barrio y "proyectos de autoayuda". En

\footnotetext{
${ }^{16}$ Según el relato que presentan los autores, el MTD Aníbal Verón caracterizó al gobierno de Kirchner como un "híbrido de burguesía nacional y corporaciones multinacionales, sustancialmente diferente de los regímenes neoliberales anteriores" (Petras y Veltmeyer, 2005:77). En ese sentido, destacan las políticas progresistas en derechos humanos, el apoyo a Fidel Castro y a Hugo Chávez, la revisión de la retrógrada legislación laboral y políticas menos represivas respecto a las protestas públicas. De la misma manera, destacan como elementos negativos la política de planes sociales en tanto factor responsable de la desarticulación y debilitamiento de los movimientos de desocupados. A partir de ese diagnóstico, el MTD Aníbal Verón adopta una postura de "apoyo crítico", retirándose de la confrontación y el conflicto a cambio de la discusión y la negociación respecto al poder político nacional. Esta postura de apoyo crítico es fuertemente cuestionada por los autores aludiendo que se trata de un diagnóstico claramente erróneo y acusando a la organización de claudicante de las causas que defendía: "EI MTD-AV deseaba aprovechar las concesiones inmediatas del régimen, a cambio de abandonar las demandas de cambios estructurales, al menos en un contexto que se percibía como un movimiento en retroceso y un régimen "popular". (Petras y Veltmeyer, 2005:78)

${ }^{17}$ EI MTR de Martino aparece con una postura mucho más crítica y opositora. Destaca como elementos centrales del gobierno de Kirchner los recortes en los planes de trabajo, el clientelismo, la ruptura entre clase media y desocupados, la falta de políticas para fábricas cerradas, la parálisis de movimientos sociales, los altos niveles de pobreza, los acuerdos de libre comercio con EE. UU. y la Unión Europea y el apoyo a industrias privatizadas. A partir de este diagnóstico, el MTR adopta una línea claramente opositora, pero, a la vez, diferenciándose de la "línea continuista" de algunas otras organizaciones opositoras (puntualmente se menciona al Polo Obrero y "trotskistas") que ven a Kirchner como una mera continuación de los viejos políticos. Martino plantea la necesidad de generar nuevos métodos de lucha que se revistan de una mayor legitimidad y que se orienten a objetivos que vayan más allá de los planes sociales, que promuevan un salario universal que incluya a toda la clase trabajadora ocupada y desocupada.
} 
definitiva, para estos autores, el creciente peso de lo barrial, la ausencia de liderazgos nacionales y la renuncia a objetivos políticos generales/nacionales sumados a la incapacidad de las organizaciones de generar conciencia de clase, explican el fracaso de la experiencia piquetera en cuanto fuerza política de transformación social.

Más allá de estos señalamientos, los mismos autores terminan afirmando que en última instancia lo que determina la fragmentación del universo piquetero es la "cuestión política", es decir las diferencias en torno al diagnóstico respecto a la nueva estructura de oportunidades políticas que surge con la asunción de Kirchner a la presidencia. ${ }^{18}$ De esta manera, la ausencia de liderazgos nacionales y la centralidad de lo local, nuevamente son ubicados en un plano secundario y las diferencias de diagnóstico -en donde los elementos político-ideológicos, aunque no estén explicitados, ocupan un papel determinante- vuelven a funcionar como la explicación última. Lo que sigue estando ausente es un análisis profundo de esos elementos que operan en la adopción de los distintos posicionamientos políticos que se observan.

Finalmente Maristella Svampa (2006b) desarrolla una tipología que categoriza a las organizaciones según la identificación con tres grandes matrices ideológicas que adquieren un fuerte peso explicativo en el análisis de la articulación política del movimiento piquetero. Este artículo en particular nos resulta de gran interés ya que se interroga centralmente sobre “¿Cuáles son los principales obstáculos que presentan los movimientos sociales en su proceso de articulación político-social?" (Svampa, 2006b:4).

La respuesta a este interrogante la autora la va a centrar en dos tópicos, por un lado los factores externos y por el otro los internos. Entre los factores externos figura, en la misma línea de Borón y Di Tella, un elemento predominante definido como la productividad política el peronismo, encarnada en este caso particular por el hábil liderazgo presidencial ejercido por el presidente Kirchner, que sintetiza legado decisionista y eficacia populista. (Svampa, 2006b:4) Por el lado de los factores internos, lo que ocupa el lugar central es la cuestión de las orientaciones ideológicas, ya que de acuerdo a la autora, "la creciente fragmentación organizacional (...) se halla ligada a las posiciones y diagnósticos asumidos por las distintas corrientes de la izquierda." Según su perspectiva "las diferentes vertientes ideológicas han potenciado el conflicto interno $y$, con ello, la división ad infinitum de movimientos $y$ organizaciones". (Svampa, 2006b:5)

La primera matriz ideológica que se señala es la de la izquierda partidaria, que estaría atravesada por una concepción marxista-leninista del poder que apunta a la

\footnotetext{
${ }^{18}$ En palabras de los autores: "Más allá de rivalidades personales, conflictos de larga data y diferencias tácticas, la división principal que atraviesa el conjunto de los movimientos de desocupados es política (especialmente en su posición y su reacción ante el gobierno de Kirchner)". (Petras y Veltmeyer, 2005:76)
} 
sustitución del sistema vigente (Svampa y Pereyra, 2003:196), ya sea a través de la acción electoral como de la acción insurreccionalista revolucionaria. Esta matriz, en la que estarían agrupados -especialmente- diferentes variantes del trotskismo, contiene una serie de componentes que operan en dirección hacia la fragmentación política tales como un alto grado de dogmatismo ideológico y una visión cortoplacista del poder, del sujeto político y de la estrategia de construcción política. ${ }^{19}$ (Svampa, 2006b:5)

Según esta perspectiva, la izquierda partidaria posee las responsabilidades más importantes en lo que hace a la fragmentación del campo popular, debido a los principales elementos -ya mencionados- que componen su matriz ideológica. Esto lleva a las organizaciones de la izquierda partidaria a cometer diversos errores tales como "negar el cambio de oportunidades políticas" que se da luego del 2003, subestimar la productividad del peronismo, todo lo que se suma a la intención de forzar su hegemonía al interior del campo militante, instrumentalizando las organizaciones de desocupados en el marco de una estrategia política impregnada por una visión "clásica" (fabril-salarial) de las sociedades actuales.

En segundo orden aparece la matriz de la izquierda populista o nacionalpopular, fuertemente vinculada a la tradición histórica del peronismo. Como elementos fundamentales que definen esta matriz serían podemos mencionar, entre otros, la promoción de un modelo de desarrollo integrador e industrialista, del pleno empleo y de un Estado interventor y benefactor. Todo esto enmarcado en el rescate de la dignidad del trabajador y de las clases populares en términos generales. La matriz populista es caracterizada por Svampa a partir de tres ejes principales: la conducción a través del líder (liderazgo carismático o personalista, con fuerte retórica nacionalista), bases sociales organizadas (figura Pueblo-Nación) y la constitución de una coalición interclases, condición para una redistribución de la riqueza más equitativa (modelo socio-económico integrador, afirmación del Estado) (Svampa, 2006b:4)..$^{20}$

\footnotetext{
19 Sujetos a esta matriz aparecen -siguiendo lo planteado en Entre la ruta y el barrio- aquellas organizaciones incluidas en el subgrupo "trotskista" del alineamiento político radical que veíamos más arriba: PO, MST Teresa Vive y FTC. Cómo puede verse, los agrupamientos según las orientaciones de la acción se aproximan a los que resultan de las orientaciones ideológicas, sin que logren coincidir plenamente.

${ }^{20} \mathrm{Al}$ igual que en el caso anterior, la matriz populista se aproxima a la línea sindical, pero la supera e incluye organizaciones alineadas según otras orientaciones de la acción. Aquí estarían incluidos las organizaciones matanceras de la línea sindical (institucionalizada) FTV y CCC, más organizaciones como Barrios de Pie, el Movimiento Evita y Quebracho. Cabe señalar que Quebracho es incluida en esta tradición ideológica en el libro Entre la ruta y el barrio (Svampa y Pereyra, 2003:195), pero no en los artículos posteriores. Esta ausencia obedece principalmente a que dicha organización adoptó una postura fuertemente crítica respecto al gobierno de Kirchner, diferenciándose claramente de sus compañeros de matriz ideológica. Intentar comprender este caso y otros similares será uno de los objetivos de este trabajo.
} 
De acuerdo a la autora, esta matriz incluye elementos que también reducen las posibilidades de articulación entre las formaciones políticas. Principalmente le adjudica una concepción del cambio social depositada en el gobierno ${ }^{21}$ que va en detrimento de "la posibilidad de un reequilibrio de fuerzas a través de las luchas sociales" (Svampa, 2006b:6). Del mismo modo se señala que la tradición nacional-popular desconfía de las "nuevas formas de autoorganización de lo social y sus demandas de empoderamiento y autonomía", lo que denota "un gran desconocimiento de las nuevas tendencias organizativas globales" (Svampa, 2006b:6).

La tercer matriz ideológica es la llamada autonomista o de la nueva izquierda. Aquí se destacan elementos tales como la necesidad de crear nuevos lazos culturales y sociales dentro del mundo popular, que apunten al desarrollo de formas de economía alternativa y solidaria respecto de la producción capitalista. (Svampa/Pereyra, 2003:195). Otro rasgo que complementa esta postura es una particular concepción del poder que busca superar las tradicionales perspectivas marxistas-leninistas caracterizadas por la centralidad del Estado en la estrategia de construcción política. En este sentido surgen conceptos como contrapoder (asociado a los MTD) el de doble poder (asociado al MTR). ${ }^{22}$

Al igual que en los casos anteriores, la autora señala una serie de elementos presentes en la matriz que también conspiran con las posibilidades de articulación política. En este sentido distingue entre la autonomía, como narrativa y matriz ideológica y el "autonomismo", entendiendo por este:

"una visión hiperbólica de la autonomía [que] presenta una crítica radical a cualquier forma de poder, aún a aquellas que apunten a la posibilidad de construir articulaciones superiores en vista de la producción de un bloque contrahegemónico. (...) la tentación hegemonizante de los partidos de izquierda no hizo más que potenciar los elementos extremos del campo autonomista, que en muchos casos confundió la defensa de la diferencia con el llamado a la pura fragmentación" (Svampa, 2006b:7).Las negritas son nuestras.

En definitiva, esta perspectiva nos acerca más a nuestro problema de investigación, en tanto se trata de pensar la articulación desde las diferentes matrices ideológicas dentro de las cuales cada organización elabora los elementos políticos e

\footnotetext{
${ }^{21}$ Se refiere, por supuesto, a gobiernos que estarían en sintonía política e ideológica con las organizaciones de esta matriz.

${ }^{22}$ En relación con la clasificación sujeta a las orientaciones de la acción, la matriz autonomista se vincula fuertemente con la línea territorial, siendo la militancia y la política local el eje de construcción privilegiado. Sin embargo, tampoco aquí aparece una concordancia total entre una taxonomía y otra, ya que la práctica territorial no necesariamente se orienta según marcos ideológicos comunes en cuanto a la concepción del poder y de la construcción política resultante. Un ejemplo de este desfasaje lo constituiría el MTD La Juanita, de La Matanza, donde no son significativos los elementos principales de la matriz ideológica autonomista pese a ser un fiel representante del alineamiento territorial.
} 
ideológicos que definirán sus identidades políticas, es decir, sus diferencias con el resto. ${ }^{23}$ Concluye Svampa que:

\begin{abstract}
"la posibilidad del surgimiento de un nuevo sujeto político que pudiera encarnar la fuerte expectativa de cambio que recorría la sociedad argentina de principios del nuevo milenio se desvaneció, no sólo ante la vuelta a la normalidad institucional encarnada por el "peronismo infinito", sino también por la abierta divergencia que se instaló entre las diferentes vertientes ideológicas que recorren el movilizado campo de las organizaciones sociales." (Svampa, 2006b:8).
\end{abstract}

Consideramos que los argumentos que brinda la autora son pertinentes y adecuados, sin embargo creemos que es necesario profundizar dicha perspectiva y responder nuevos interrogantes que surgen de lo planteado por Svampa. Para el primer grupo: ¿En qué consiste el dogmatismo de la izquierda tradicional? ¿Sobre qué lógicas se apoya y de qué manera opera? ¿Por qué se minimizan los cambios en la estructura de oportunidades políticas? ¿Qué visión/valoración elaboran respecto a adversarios, enemigos, aliados, etc.? Para el segundo: ¿En qué sentido las formaciones políticas de la matriz nacional-popular "renuncia a las luchas sociales"? ¿En qué componentes ideológicos descansan sus valoraciones sobre el Estado y sobre las "nuevas formas de militancia"? ¿Qué discusiones están detrás? ¿Qué lleva a una organización como Quebracho a adoptar una posición de radical oposición a un gobierno respaldado por las otras organizaciones de la matriz nacional-popular? Por último ¿En qué consiste la "narrativa autonomista"? ¿De qué modo aparece en las formaciones políticas concretas? ¿Qué rasgos político-ideológicos identificamos? ¿Qué vigencia/centralidad tienen hoy en las organizaciones?

En el presente trabajo intentaremos dar respuesta a estas y otras preguntas a partir de un análisis detallado de los elementos político-ideológicos que configuran los discursos de algunas de estas organizaciones. Intentaremos profundizar las clasificaciones presentadas hasta aquí en las que se inscriben las distintas organizaciones, para desde allí, pensar sus implicancias en relación a la articulación política. Como señalábamos en la introducción, creemos que resultará útil diferenciar entre los distintos tópicos - desde las grandes concepciones de lo social hasta las valoraciones sobre la coyuntura política concreta- en torno de los cuales se estructuran los elementos político-ideológicos que configuran los discursos identitarios. De esta manera intentaremos identificar en torno a qué elementos se establecen las diferencias más relevantes para cada organización y el modo en que son formuladas tales diferencias. Como decíamos anteriormente, haremos especial hincapié en la

23 En este sentido concebimos a las matrices ideológicas como grandes posicionamientos, como coordenadas generales que remiten a un determinado acervo histórico al interior de las cuales se constituyen diversas orientaciones que se encarnan en organizaciones concretas. El marxismo sería un ejemplo de matriz, al interior de la cual surgen orientaciones o vertientes como el maoísmo, el trotskismo o el guevarismo, que tienen sus expresiones en diferentes organizaciones específicas. 
fijación de sentido con la que se presentan tales elementos ya que entendemos que se vincula con las posibilidades de establecer consensos y, por tanto, con la viabilidad de desarrollar procesos de articulación política de alta intensidad. El análisis de la pretensión de verdad con la que se presentan los distintos discursos constituye una variable que sobrevolará la exploración de cada uno de estos elementos en cada una organizaciones. 


\section{PLANTEAMIENTO DEL PROBLEMA}

Siguiendo este planteo, nuestro problema de investigación queda planteado de la siguiente manera: ¿Qué elementos político-ideológicos configuran las identidades de las distintas organizaciones en el movimiento piquetero y qué incidencia tienen respecto a las diferentes modalidades que adquiere la constante tensión entre articulación/fragmentación política en el campo popular?

Nos interesa observar el modo en que se construyen las identidades y las diferencias al interior del espacio y hacia su exterior; de qué manera se van construyendo los distintos nosotros (la organización, el ala combativa del movimiento piquetero, el campo popular, etc.) y los distintos ellos (las "organizaciones amigas del campo popular", los "enemigos del campo popular", etc.). Es decir, el Polo Obrero (PO) produce un discurso que lo identifica como integrante del movimiento piquetero y del campo popular, a partir de elementos comunes con otras formaciones de esos mismos conglomerados y de diferencias con aquellas que no forman parte de dichos campos: "el poder", "la derecha", etc. Simultáneamente, el PO establece nuevas diferencias que lo distinguen de otras formaciones al interior del movimiento piquetero y -por tanto- del campo popular: "los maoístas", "los nac \& pop", "los autonomistas", etc.

Mediante estas operaciones de identificación y diferenciación es que se configuran los espacios en los que se desarrollan las estrategias políticas, las que están atravesadas por procesos de articulación y fragmentación. Confiamos en que la indagación sobre cómo se desenvuelven las operaciones de identificación y diferenciación nos acercará a una mejor comprensión de las modalidades que adquiere la tensión articulación/fragmentación de las formaciones políticas del campo popular argentino.

Como venimos diciendo, partimos del supuesto de que los rasgos que adquieren los procesos de articulación están fuertemente vinculados con los elementos político-ideológicos a partir de los cuales se construyen sus discursos identitarios. También señalamos que tales elementos resultan de las lecturas y posturas que cada organización hace en relación a diferentes tópicos o dimensiones tales como las características que debiera adoptar el orden social futuro ("punto de llegada"); el modo de alcanzarlo (revolución, reforma...); la apelación a determinados sujetos sociales; la presunción sobre su representatividad; el peso de la "cuestión nacional"; las modalidades de lucha; la centralidad de las definiciones políticas coyunturales; o la definición de los principios organizativos. En cada una de estas dimensiones se establecen posiciones que resultan más o menos diferentes y que a la vez se plantean con mayor o menor rigidez, con mayor o menor fijación de sentido. 
La decisión de distinguir una serie de dimensiones como las recién expuestas permite diferenciar los distintos puntos nodales ${ }^{24}$ en torno de los cuales las organizaciones establecen las semejanzas y diferencias que les resultan más relevantes. Dicho de otro modo, nos permite poder identificar cuáles son los elementos político-ideológicos específicos alrededor de los cuales se establecen las fronteras que operan con mayor intensidad en la distinción entre una organización y otra. Esto es, entre el vasto conjunto de elementos que se incluyen en las llamadas "diferencias ideológicas", poder distinguir con un mayor grado de precisión, aquellos que resultan más relevantes que otros de acuerdo al discurso identitario de la organización.

Siguiendo estos lineamientos consideramos que podremos avanzar en dar respuestas a las preguntas que guían esta investigación, aportando a la caracterización tanto de la identidad política de las distintas organizaciones, como de las matrices ideológicas en las que se inscriben tales identidades.

\footnotetext{
${ }^{24}$ Ver el siguiente apartado.
} 


\section{ALGUNAS DEFINICIONES CONCEPTUALES}

\section{Sobre lo ideológico}

El concepto de ideología ha sido y es utilizado con significados muy diversos lo que nos obliga a establecer cual es el uso que le daremos en nuestro trabajo. Sus primeras apariciones datan de los trabajos de los psicologistas franceses hacia finales del siglo XVIII, en particular los trabajos de Cabanis y Destutt de Tracy. ${ }^{25}$ En estos primeros usos, su significado remitía al estudio genético de las ideas, es decir, a la exploración de los orígenes y las leyes que rigen el funcionamiento de las ideas.

Luego de estas primeras nociones, el quiebre más significativo es el que produce la obra del joven Marx, en la que el concepto de ideología es utilizado para dar cuenta del conjunto de ideas ilusorias que en determinado modo de producción se construyen como mecanismo de dominación para legitimar la explotación de una clase social sobre otra. De este modo, en gran parte de la tradición marxista, el concepto de ideología se asocia con "distorsión", con "encantamiento", con visiones de la realidad que no reflejan la verdad y que se oponen al saber verdadero, es decir, científico. Desde esta perspectiva, lo ideológico remite a los dispositivos "superestructurales" que las clases dominantes construyen para ocultar y/o legitimar los mecanismos de explotación y sumisión sobre los que basan su dominación social. ${ }^{26}$

Una tercera acepción del término ideología, quizás la más corriente, es la que mejor se adecúa a los propósitos de nuestro trabajo y es la que refiere al "conjunto de ideas fundamentales que caracteriza el pensamiento de una persona, colectividad o época, de un movimiento cultural, religioso o político", especialmente aquellas "tendientes a la conservación o la transformación del sistema existente" ${ }^{27}$. Es decir, no se trata ya del estudio genético de las ideas ni tampoco de mecanismos de dominación productores de falsa conciencia, sino de un conjunto de ideas, llamadas fundamentales, que permiten elaborar una determinada concepción del mundo social que es comprendido, analizado y explicado siguiendo los lineamientos que este conjunto de ideas establece y que, a la vez, es portador de una función política ya sea conservando o subvirtiendo los valores de determinado orden social.

En este sentido, no se está lejos del concepto de cosmovisión (Weltanschauung) introducido por el filósofo alemán Wilhelm Dilthey a principios del siglo XX, que luego va a ser recuperado por diversos autores como Eric Hobsbawm (1971) cuando se refiere a las tres grandes ideologías que se disputan la explicación del universo social

\footnotetext{
${ }^{25}$ Ver Capdevilla, N., 2006.

${ }^{26}$ Desde Lukács a Althusser pasando por Gramsci, Adorno y otros, los intelectuales marxistas han problematizado y profundizado en torno a la noción de ideología dando lugar a debates de suma relevancia. Una buena síntesis de estos debates figuran en el trabajo de Slavoj Zizek ([1994] 2003) Ideología. Un mapa de la cuestión.

${ }^{27}$ Ver Diccionario de la Real Academia Española, Tomo II, 21ra edición, Madrid [1992] 1995.
} 
a partir de las revoluciones burguesas -liberalismo, conservadorismo y socialismo-; o el caso de Robert Nisbet (1969) cuando hace alusión a las grandes tradiciones ideológicas que interactúan en la formación del pensamiento sociológico. En relación a nuestro objeto de estudio, el estudio de las matrices y orientaciones ideológicas presentes en las diferentes organizaciones ha sido trabajado en múltiples oportunidades. Los trabajos de Svampa y Pereyra (2003) o el de Petras-Veltmeyer (2005) ya citados son solo una muestra del uso del concepto de ideología en esta tercera acepción, la que adoptaremos en el presente trabajo.

Para avanzar en su definición al interior de estas últimas coordenadas podemos enumerar una serie de rasgos que sistematiza Teun Van Dijk en Semántica del discurso e ideología (2008). En una primera definición provisoria se refiere a las ideologías como "sistemas básicos de cognición social, como elementos organizadores de actitudes y otros tipos de representaciones sociales compartidas por miembros pertenecientes a un grupo".(2008:202) De esto modo hay, en primer lugar, dos rasgos que resultan cruciales en la definición de la ideología: por un lado, las ideologías son cognitivas, estos es, incluyen objetos mentales (ideas, creencias, pensamientos, juicios y valores) constituyéndose en la "base axiomática" de "sistemas de creencias".(2008:204) Por otro lado, las ideologías son sociales, están presentes en diversos grupos (dominantes y dominados) y se materializan en actitudes y representaciones sociales comunes; "se comparten mediante marcos interpretativos". (2008:205)

Luego continúa destacando otras características que permiten precisar mejor los alcances del concepto. Una de ellas es que las ideologías no son 'verdaderas' o 'falsas', o más precisamente, que no pueden definirse en términos de verdad o falsedad. Esto no significa que no se pueda constatar que determinados supuestos de una ideología son verdaderos o falsos: las creencias de los racistas sobre los negros, las de los machistas sobre las mujeres o las de los ecologistas sobre los niveles de polución existentes. Lo que quiere destacar es que "las ideologías representan la posibilidad partidista de verdad 'autoservida' de un grupo social”. En este sentido las ideologías son entendidas como "marcos de interpretación (y acción) más o menos relevantes y eficientes para aquellos grupos que son capaces de llevar más allá los intereses del grupo". (2008:206) Aparecen aquí una serie de elementos que nos parecen fundamentales: se trata de marcos de interpretación que, independientemente de su "verdad/falsedad", se evalúan a partir de la relevancia y la eficiencia en la capacidad del grupo de llevar sus intereses más allá, es decir, hacia otros grupos, hacia el resto de la sociedad. 
Del mismo modo destaca que las ideologías pueden tener diversos grados de complejidad, ya que no se limitan a los grandes ismos, sino que incluyen los "axiomas básicos implícitos en la teoría social que tiene un grupo sobre sí mismo y sobre su posición en la sociedad" (2008:207). Tampoco tienen un poder determinante sobre las producciones del discurso, sino que presentan manifestaciones contextuales variables, sujetas a la influencia de otros factores sociales, sociocognitivos y personales. Por último, más allá de sus manifestaciones, las ideologías son generales y abstractas, lo que se observa en las similitudes de las acciones y discursos de los miembros de un grupo independientemente del contexto específico del que se trate.

Luego de estas aproximaciones preliminares, Van Dijk define a las ideologías del siguiente modo:

\begin{abstract}
Las ideologías son marcos básicos de cognición social, son compartidas por miembros de grupos sociales, están constituidas por selecciones de valores socioculturales relevantes, y se organizan mediante esquemas ideológicos que representan la autodefinición de un grupo. Además de su función social de sostener los intereses de los grupos, las ideologías tienen la función cognitiva de organizar las representaciones (actitudes, conocimientos) sociales del grupo, y así monitorizar indirectamente las prácticas sociales grupales, y por lo tanto también el texto y el habla de sus miembros. $(2008: 208)^{28}$
\end{abstract}

Las ideologías así entendidas constituyen marcos básicos de cognición social, a partir de la selección de una serie de valores socioculturales que se comparten entre los miembros de la organización ${ }^{29}$, que actúan en el sostenimiento de los intereses del grupo, en el modo de concebir y conceptualizar el mundo social y como esquema de monitoreo de las prácticas. Es decir, entre las organizaciones políticas que estudiamos, las ideologías funcionan como un elemento de cohesión -la posibilidad de desarrollar acuerdos y posicionamientos compartidos- a partir de determinadas lecturas y explicaciones sobre la realidad social que derivan en prácticas políticas determinadas. Los llamados elementos políticos ideológicos remiten a una serie de puntos del discurso identitario de cada organización que incluyen desde visiones y posicionamientos respecto a la relación entre la dimensión de lo económico y la de lo político, hasta las posturas sobre la insurrección como herramienta privilegiada de construcción política. Creemos que esta definición, sumada a los rasgos señalados

\footnotetext{
${ }^{28}$ El modo en que se vincula lo grupal con lo individual es tratado por este autor mediante los conceptos de actitud y modelo. Más adelante hablaremos sobre ellos.

${ }^{29}$ La relación entre dirigentes y no dirigentes al interior de las organizaciones incluye múltiples formas de aparición. En este sentido, cuan compartidos resultan los marcos básicos de cognición social, no es un interrogante que buscamos responder en este trabajo. Si creemos que la definición resulta adecuada al menos en lo que refiere a los grupos dirigentes de cada organización, quienes comparten tales ideologías y, a partir de ellas, establecen los lineamientos generales entre los que se actuará en el terreno política. En el mismo sentido, entendemos que estos grupos dirigentes pretenden que la ideología sea compartida, en primer lugar por el conjunto de la organización y luego más allá de ella.
} 
anteriormente, resulta lo suficientemente precisa y útil para los fines de nuestro trabajo y nos sirve para enmarcar el análisis que nos proponemos aquí.

\section{Articulación y hegemonía}

Una de las perspectivas que nos resultan apropiadas para avanzar en el estudio de la articulación política desde el tipo de preguntas que nos hemos planteado hasta aquí, es la que proponen Ernesto Laclau y Chantal Mouffe, especialmente a partir de su conocido trabajo Hegemonía y estrategia socialista. Hacia una radicalización de la democracia ([1985] 2006). Allí los autores desarrollan el tema de la articulación política desde las posibilidades que presentan determinados discursos políticos, específicamente los que se inscriben en el marxismo, para el desarrollo de procesos hegemónicos de articulación, estableciendo los principales elementos de la que luego será conocida como la Teoría del Discurso.

Como bien señala Ana Soage (2006), los antecedentes de la Teoría del Discurso pueden encontrarse en una larga lista de aportes. Desde que a principios del siglo pasado Ferdinand de Saussure diferenció entre la lengua (como sistema) y el habla (como acto); identificó al signo como el elemento básico de la lengua; diferenció en su interior al significante y al significado; y estableció el carácter relacional que adquieren los signos entre sí; los análisis lingüísticos tuvieron su plataforma para ir adquiriendo un status cada vez más definido y para que los cientistas sociales le otorgaran cada vez mayor relevancia y centralidad. Esta tendencia explotó recién a partir de la década del sesenta, en lo que se dio en llamar el "giro lingüístico", movimiento filosófico en el que figuras como Michel Foucault, Roland Barthes y Jacques Derrida, entre otros, buscaron desentrañar las lógicas que operan en la construcción y en el funcionamiento de los discursos, su carácter condicionado y condicionante al mismo tiempo (Soage, 2006). Quizás sea la proposición de Derrida "Il n'y pas de hors-texte" (No hay nada más allá del texto) la que resume la centralidad que adquiere el análisis del discurso en el estudio de lo social. ${ }^{30}$

Es al interior de estas coordenadas que Laclau y Mouffe ([1985] 2006) exploran el recorrido del concepto de hegemonía en la teoría marxista, analizando sus cambios y características en busca de elementos para una teoría de la articulación política. En ese camino analizan diferentes principios fundamentales de la teoría marxista que,

\footnotetext{
${ }_{30}$ Algunos interpretaron tal sentencia como una reducción de la realidad al discurso. Sin embargo entendemos con Soage (2006:51) que el sentido de la proposición refiere a que la realidad sólo es aprehensible mediante el discurso, es decir, inevitablemente atravesada por la multiplicidad de elementos presentes en el funcionamiento del discurso. No podemos dejar de señalar el evidente parentesco entre esta idea y la distinción lacaniana entre lo real, lo simbólico y lo imaginario, otro de los antecedentes fundamentales de la Teoría del Discurso.
} 
según su perspectiva, operan fuertemente en las concepciones y estrategias de articulación que suelen estar presentes en las formaciones políticas de izquierda.

La perspectiva que proponen discute con diferentes concepciones clásicas de la tradición marxista a las que se les cuestiona, en términos generales, la persistencia de elementos deterministas y esencialistas -economicismo, etapismo, etc.- que otorgan un escaso margen al plano de lo político y que por tanto condicionan fuertemente los procesos de articulación y de hegemonía. Los conceptos de hegemonía y de articulación que proponen los autores aparecen de este modo buscando resaltar el papel de lo político y de lo contingente, rompiendo con principios ontológicos de lo social que niegan o limitan fuertemente el espacio de las operaciones políticas. En palabras de los autores:

"La práctica de la articulación consiste en la construcción de puntos nodales que fijan parcialmente el sentido; y el carácter parcial de esa fijación procede de la apertura de lo social, resultante a su vez del constante desbordamiento de todo discurso por la infinitud del campo de la discursividad" ([1985] 2006:154)

Articulación remite aquí a un tipo específico de relación que parte de la imposibilidad de las identidades plenas y de la fijación total de significados. En tal contexto, adquiere una centralidad decisiva la presencia de significantes vacíos en los que los significados son reelaborados y reordenados -siempre de un modo parcial- de acuerdo objetivos políticos específicos, reconfigurando el espacio político mediante lógicas de equivalencia y diferencia. Cuando de articulación política se trata, el significante vacío por excelencia es el de pueblo, en el que se condensan el todo y la parte, el demos y la plebs. ${ }^{31}$

Cabe una aclaración sobre el concepto de articulación que los autores trabajan en aquel texto, en tanto según dicha propuesta, en la articulación "la identidad de los elementos se ve modificada como resultado de esa práctica" ([1985] 2006:142). Para referirnos a este tipo específico de relación y diferenciarla de otros tipos de articulación, hablaremos de articulación de alta intensidad, para de ese modo conservar el concepto de articulación -a secas- en un sentido más amplio, como las diferentes maneras en que las formaciones políticas se asocian y actúan de manera conjunta, más allá de la profundidad/intensidad que adquieren dichas articulaciones.

En la misma línea, la hegemonía es concebida como un tipo de práctica articulatoria cuya particularidad radica en estar atravesada por un antagonismo, la articulación se realiza en oposición a otra articulación:

\footnotetext{
${ }^{31}$ En La razón populista,(FCE, 2005) Laclau va profundizar esta línea de trabajo sobre los usos del pueblo como significante vacío para la articulación política.
} 
"Para hablar de hegemonía no es suficiente el momento articulatorio, es preciso además que la articulación se verifique a través de un enfrentamiento con prácticas articulatorias antagónicas". ([1985] 2006:179)

La hegemonía aparece entonces en estos autores como una práctica articulatoria eminentemente política, en la que se rechazan las identidades plenas y los discursos cerrados y totalizantes de lo social, a la vez que incluye la existencia de un conflicto antagónico que la atraviesa.

Para Laclau y Mouffe, la práctica articulatoria implica el desarrollo de discursos capaces de articular en su interior diversas posiciones diferenciales (elementos), que una vez articulados en el discurso se constituyen en momentos del discurso. Las posiciones diferenciales son concebidas como posiciones de sujeto, es decir que la articulación se plantea entre subjetividades. En su reciente trabajo sobre el populismo (2005), Laclau define como la unidad mínima de la articulación populista a las demandas sociales, de modo que el proceso de articulación mediante significantes vacíos que establecen lógicas equivalenciales se da al nivel de las demandas sociales insatisfechas de los sujetos. Es decir, son las demandas de los sujetos las que se articulan, equivalencialmente, en torno a un significante que es vaciado y resignificado en función de su rol articulador hegemónico. Dicho de otra manera: los sujetos se articulan mediante la presencia de un significante que logra equivalenciar sus demandas. (2005:97-99)

Creemos que esta misma lógica puede aplicarse, sin ser violentada, al nivel de las organizaciones, entendiendo por estas a colectivos sociales, "como sujeto que irrumpe en la escena política pública, cuya característica principal está dada por las demandas que lo constituyen como tal" (D'Amico y Pinedo, 2008:2), que presentan determinados grados de homogeneidad, determinada identidad común, en relación a sus orientaciones políticas e ideológicas (actitudes en Van Dijk) ${ }^{32}$. Retomando un ejemplo mencionado por Laclau: el significante Perón en los 70 significaba una multiplicidad de significados (patria socialista, patria peronista, etc.) y equivalenciaba una multiplicidad de demandas (revolución para unos, orden para otros, etc.). Estos significados, estas demandas, interpelaban tanto a las subjetividades "sueltas", como a aquellas que conformaban y "daban voz" a las distintas organizaciones políticas. Es decir, la CGT, las FAR, las FAP, Descamisados, el Peronismo de Base y Montoneros, etc., atraviesan por un proceso de articulación hegemónica en torno del significante punto nodal ${ }^{33}$ - Perón y el discurso que él representa.

\footnotetext{
${ }^{32}$ Resulta útil en este sentido el concepto de formación política definido en el siguiente apartado. También la distinción ya mencionada que hacen D'Amico y Pinedo (2008).

${ }^{33}$ Laclau y Mouffe definen a los punto nodales como aquellos puntos discursivos privilegiados en donde en se efectúan ciertas fijaciones de sentido. Se vincula con el concepto lacaniano de points de capito que refiere a "ciertos significantes privilegiados que fijan el sentido de la cadena significante" (Laclau y Mouffe [1985] 2006:152)
} 
Vale insistir en que no queremos decir que se trate de procesos de articulación de la misma naturaleza, pero sí que pueden pensarse de modo similar a partir del uso de las categorías que Laclau y Mouffe desarrollan. Los discursos identitarios que presentan las diferentes organizaciones que estudiamos en esta investigación definen toda una serie de posicionamientos diferenciales político-ideológicos sobre diversos temas: clases sociales, sujetos políticos, Estado, mecanismos políticos institucionales, lucha armada, insurreccionalismo, enemigos, aliados, etc. En nuestro trabajo nos interesa observar las diferentes fijaciones de sentido que se observan en torno a ese tipo de definiciones para observar así las posibilidades que se abren para desarrollar lógicas equivalenciales y, de ese modo, procesos de articulación, en el sentido en el que lo plantean los autores.

Por todo esto, creemos que esta perspectiva resulta de gran utilidad para una investigación como la que nos proponemos ya que nos lleva a explorar el modo en que se construyen y reconstruyen las identidades políticas de cada una de las formaciones políticas, cómo se interpretan y significan distintos temas, cómo se posicionan las organizaciones frente a diferentes contingencias políticas, qué lógicas de equivalencia y de diferencia se construyen, en definitiva en base a qué elementos político ideológicos se construyen las identidades y las diferencias.

\section{Identidad y Diferencia Política}

Otra perspectiva que nos interesa, y que se inscribe en la misma línea propuesta por Laclau y Mouffe, es la que desarrolla Gerardo Aboy Carlés, presente en diversos trabajos (2001 y 2005), y que nos ayuda sintetizar otros elementos hasta aquí no desarrollados. Este autor parte de una concepción básica de identidad y diferencia, las que constituyen dos caras de una misma moneda, dos conceptos que se explican mutuamente, que se necesitan. Es decir, se retoma una de las ideas centrales de Saussure sobre el carácter relacional del lenguaje.

Una primera aproximación al concepto de diferencia nos lleva a la idea de "cualidad o accidente que permite distinguir una cosa de otra" (Aboy Carlés, 2001:45). Del mismo modo, dicha cualidad o accidente no puede ser concebida como una propiedad que en sí misma constituye la identidad de la cosa. La identidad se inscribe en un orden simbólico, un sistema de relaciones, en el cual los límites que marcan las diferencias -las fronteras en las que se inscriben las identidades- son discernibles. Como señala el autor, David parecía débil sólo en presencia de Goliat. ${ }^{34}$ Como se empeña en destacar el autor, "identidad y diferencia son la condición y la inauguración

\footnotetext{
${ }^{34}$ Nosotros podemos decir que Quebracho aparece como una agrupación violenta al lado de Partido Socialista, pero no en comparación con las FARC.
} 
misma de sentido". Decimos que algo es una cosa porque estamos señalando que no es otra. A es A en tanto no es B.

Ahora bien, ¿Cómo se establece el sentido en el escenario de la práctica política? ¿De qué manera podemos aprender la constitución de identidades políticas? En primer lugar, Aboy Carlés destaca un doble registro en el que resulta necesario abordar esta problemática: un registro topológico/estático/espacial y un registro historicista/dinámico/temporal. La dialéctica entre estos pares conceptuales ha sido abordada por varios autores quienes más allá de sus especificidades, coinciden en destacar este doble abordaje.

Para desarrollar esta idea, Aboy Carlés incorpora el rescate que Laclau hace de Husserl respecto a las nociones de "sedimentación" y "reactivación" para dar cuenta del carácter contingente de toda identidad. La "sedimentación" aparece como el conjunto de prácticas culturales acumuladas que a lo largo del tiempo configuran el telón de fondo sobre el que se inscribe cada acto de institución. Laclau asocia la sedimentación con lo social, y daría cuenta del registro estático y topológico de las identidades constituidas.

Pero por lo que venimos señalando, la constitución de las identidades se da siempre de un modo parcial, en la medida que constantemente se producen actos constitutivos que operan sobre lo sedimentado, que "reactivan" lo social. Para Laclau, señala Aboy Carlés, este es el escenario de lo político, la constante modificación de lo social, es decir de lo político sedimentado.

Desde el registro topológico, la identidad y la diferencia se constituyen al interior de un sistema diferencias, que a la vez se construye frente a un exterior, que no es otra cosa que una nueva diferencia. Ese exterior permite constituir al sistema como totalidad, pero al ser el resultado de una operación hegemónica, parcial y contingente, la totalidad deja de ser tal.

El exterior debe ser algo que ponga en cuestión las diferencias intra-sistema. El "campo popular" argentino puede hacer causa común contra el imperialismo norteamericano, suprimir las diferencias del sistema "campo popular" y constituirse como totalidad articulada -al menos de baja intensidad-. Como señalábamos, este proceso se desarrolla según lo que Laclau y Mouffe denominaron lógica de equivalencia.

El cierre de un espacio de equivalencias frente a un exterior se da a partir de una operación hegemónica a partir de la cual un particular se transforma en universal y permite la delimitación con el exterior. Al tratarse de equivalencias, el cierre siempre es parcial y la identidad nunca puede constituirse plenamente. En palabras de Aboy Carlés: 
Para Laclau, la constitución de equivalencias, el cierre de un espacio de diferencias frente a un exterior, tiene siempre la forma de una operación hegemónica: un particular que se convierte en universal aglutinando un espacio político frente a una alteridad, lo que implica la no realización plena de la identidad de todas las fuerzas equivalentes dentro del espacio constituido. (2001:49)

Volviendo a nuestro ejemplo simple, podemos decir que el espacio político del campo popular se logra articular a través del particular "antiimperialismo", que se constituye en un universal y aglutina así a los sujetos en contra de los representantes, socios, aliados o simpatizantes del imperialismo.

Esta dialéctica entre lo topológico y lo histórico adquiere el nombre en Laclau de identidad y acto de identificación. La identidad sería lo social sedimentado mientras que el acto de identificación el proceso en el que se le imprime un nuevo sentido a lo ya existente. El modo en que interactúa lo nuevo con lo viejo, los nuevos sentidos con lo ya constituido van a adquirir diferentes características.

En su recorrido hacia una definición de identidad política, siguiendo algunas de las líneas trazadas por Laclau, Aboy Carlés va a introducir con gran centralidad el concepto de significante vacío o flotante, el cual aparece definido como un "significante sin significado, una subversión de la estructura del signo que cancela su significación" (2001:50), es decir el significante no responde a un significado único específico, sino que es articulado con diferentes significados según la operación hegemónica de la que se trate. Desde esta perspectiva toda identidad política se va a construir a través de una lógica de equivalencia encarnada en significantes vacíos que permiten articular el campo político en cuestión.

Llegado a este punto, Aboy Carlés tematiza sobre el tipo de operación que establece el significante vacío en relación con lo sedimentado. La relación entre la identidad -siempre parcial- constituida por lo sedimentado y el acto de identificación, como la institución de nuevos sentidos, establece el modo en que se da la operación hegemónica que deriva en la conformación de la identidad política. En palabras del autor: "la presencia del significante vacío es la forma del límite entre la identidad y el acto de identificación" (2001:52).

De esta manera nos acercamos a los conceptos de formación y de identidad políticas. La formación política, siguiendo lo dicho hasta ahora, aparece como una "configuración de identidades constituidas a través de matrices sedimentadas de acción a las que bien podríamos llamar habitus o rutinas" (2001:54). La subversión y transformación de estas matrices sedimentadas, a partir de la operación de los significantes vacíos, explica la parcialidad y contingencia de toda formación política y de toda identidad. Del mismo modo, las características que adquiere en cada caso tal 
transformación, nos remite a las variantes de fijación de sentido con las que las organizaciones estructuran sus discursos identitarios.

Si el grado de contingencia es absoluto o no, es una discusión que supera el interés de este trabajo. Desde el punto de vista lógico, es aceptable que la contingencia opere sin ataduras ni límites, pero las probabilidades de que esto así sea en el campo de las formaciones políticas disminuye a partir del "telón de fondo" que limita, aunque siempre de un modo parcial, la operación del significante vacío. ${ }^{35}$

Arribamos por último a la definición de identidad política que presenta el autor la que es entendida como:

"el conjunto de prácticas sedimentadas, configuradoras de sentido, que establecen, a través de un mismo proceso de diferenciación externa y homogeneización interna, solidaridades estables, capaces de definir, a través de unidades de nominación, orientaciones gregarias de la acción en relación a la definición de asuntos públicos." (2001:54)

Como vemos, existen fuertes puntos de encuentro entre esta definición y la de ideología que nos ofrecía Van Dijk. A partir de estas coordenadas, elementos y concepciones creemos que podremos avanzar en las líneas trazadas por nuestra investigación, aportando a la comprensión de los elementos que operan en la tensión de la articulación y la fragmentación que nos proponemos estudiar.

\footnotetext{
${ }^{35}$ Un modo en que el autor busca responder este asunto -el de la manera en que la institución nueva de sentido es condicionada por lo parcialmente objetivado- es partir del rescate del concepto de mito de Roland Barthes. El mito aparece en este autor como un sistema semiológico segundo, es decir que se edifica a partir de un sistema semiológico primero y sobre él opera. Para ejemplificar esto, Aboy Carlés menciona el proceso a través del cual sectores de la izquierda argentina asocian el nacionalismo y marxismo, destacando la condición de "construcción de segundo orden" y de "lenguaje robado" (2001: 57)
} 
V. CUESTIONES METODOLÓGICAS 


\section{Tres dimensiones}

Daniel Saur (2006) distingue en un breve artículo tres dimensiones para la investigación de los discursos sociales. En verdad, la preocupación que guía las páginas de su artículo es la de cómo desarrollar un tipo de conocimiento que sea innovador, original y útil, escapando de los procedimientos y lógicas que imperan en el ámbito académico, las que desde su perspectiva resultan asfixiantes. Retomando algunas reflexiones de Foucault, el autor señala que el desafío más importantes es lograr lo que el filósofo francés denominaba "pensar de otro modo", romper las lógicas y estructuras vigentes en los sistemas teóricos y paradigmas. La aparición del pensamiento nuevo, el pensamiento no previsto, se explicaba en Foucault por el azar, en tanto las técnicas y procedimientos metodológicos se veían fuertemente asociados con lo estatuido, lo imperante, el no cambio. El desafío que destaca Saur es justamente el de poder establecer algunas pistas, algunas coordenadas metodológicas que sirvan para hacer surgir el "pensar" foucaultiano, sin dejar al investigador a la deriva de lo aleatorio.

Es en esta empresa que Saur recomienda tres dimensiones para que sean cuidadosamente estudiadas y resueltas en pos de avanzar en un "pensar de otro modo": el posicionamiento onto-epistemológico, la delimitación del objeto a investigar y búsqueda de metáforas concordantes. El primer punto implica tres elementos interconectados: la propiedad de los objetos a investigar (su "luminosidad", sus atributos observables), los dispositivos del observador (las herramientas, el dispositivo analítico-interpretativo) y el lugar onto-epistemológico, en donde se destaca el paradigma teórico desde el que se interpela a la realidad seleccionada. La delimitación del objeto implica cotejar el fondo teórico y la experiencia investigativa, es decir, las coordenadas resultantes de la primera dimensión. Por último, la tercer dimensión remite a la creación de nuevos conceptos, nuevas metáforas que permitan pensar de nuevas formas, desafiando lo existente, resignificando y discutiendo los discursos predominantes.

Creemos útil detenernos a reflexionar sobre estos lineamientos propuestos por el autor. En los apartados anteriores buscamos identificar tanto los aportes y limites que presentaban los diferentes abordajes sobre nuestro tema, como los conceptos teóricos que van prefigurando las características del enfoque que tiene nuestra investigación. A continuación nos detendremos en distinguir algunas dimensiones del análisis del discurso, las técnicas y fuentes de información $\mathrm{y}$, por último las características de la muestra sobre el que se basa nuestro trabajo. Consideramos, que en líneas generales, hemos creado las condiciones -no aleatorias- para discutir con varios de los planteos observados, para pensar de otro modo. Veremos si lo logramos. 


\section{Análisis del discurso}

Uno de los elementos que nos resultan interesantes del trabajo de Van Dijk citado anteriormente (2008), es la manera en que conceptualiza el modo en que la ideología se hace presente en el individuo y así, en su discurso. Los dos conceptos más importantes en este sentido son el de actitud y modelo. De este modo las actitudes remiten a los elementos ideológicos comunes, "compartidos en las opiniones $y$ en los esquemas mentales sobre temas sociales" por los miembros de determinado grupo; mientras que los modelos se definen como una suerte de "interfase cognitiva" que permiten la traducción de las actitudes -sociales, ideológicas- al plano particular, personal, subjetivo. Como señala Van Dijk, se trata de "representaciones mentales que se usan para procesar (la producción del discurso o la comprensión) en ambos sentidos" (2008:214).

El interés por recuperar esta conceptualización radica en que el modelo constituye la forma de aparición de la ideología en los individuos. Si bien en esta investigación se trabaja con publicaciones (discursos) institucionales de cada organización, también apelamos a entrevistas en profundidad a referentes de las organizaciones estudiadas. Allí observaremos el acervo ideológico de las distintas organizaciones encarnadas en los modelos de sus máximos referentes.

Desde esta perspectiva enmarcamos nuestro análisis semántico del discurso, el que requiere tener presente toda una serie de elementos que ayudan estar atentos e indagar satisfactoriamente los significados, latentes y manifiestos, presentes en el discurso. De esta manera se pueden identificar una serie de elementos y aspectos que resultan de importancia para avanzar en investigaciones como las que aquí nos proponemos.

Las proposiciones constituyen la forma de aparición más común y elemental de los discursos y sus significados. En ellas ha de tenerse en consideración las "modalidades de 'necesidad' y 'probabilidad" con la que se presentan las diferentes sentencias; el modo en que se presentan en los predicados los actores ajenos al grupo; los "roles semánticos de los argumentos proposicionales" (por ejemplo vinculados a la responsabilidad otorgada a determinado actor en relación a determinado hecho); y toda una serie de propiedades de las proposiciones en las que pueden identificarse las cargas ideológicas que suelen resumirse en las nociones de perspectiva, punto de opinión o posición (Van Dijk, 2008:221-222). ${ }^{36}$

\footnotetext{
${ }^{36}$ Finalmente Van Dijk señala otros elementos y aspectos de relevancia para incorporar y tener presentes en el análisis del discurso que, si bien no serán explicitados ni enumerados en detalle a lo largo de nuestro trabajo, indudablemente formarán parte y sobrevolaran el análisis de esta investigación. Tales elementos y aspectos a tener en cuenta son: la lexicalización, mediante la cual determinados significados se asientan y naturalizan a la luz de determinado andamiaje ideológico; los rasgos morfológicos de las
} 


\section{Fuentes y técnicas de recolección de datos}

Dadas las características del enfoque propuesto decidimos trabajar con dos tipos de técnicas principales que nos parecen pertinentes para nuestra perspectiva de trabajo. En primer lugar están las entrevistas personalizadas a informantes clave las que fueron semi-estructuradas y abiertas y orientadas a los principales dirigentes de cada una de las formaciones políticas en cuestión. En este sentido elaboramos un cuestionario recorriendo los ejes centrales acordes con nuestra perspectiva de análisis y lo implementamos en cada uno de los casos buscando obtener información que nos permita desarrollar comparaciones claras y directas. Las entrevistas resultantes fueron de alrededor dos horas cada una, pudiendo explorar en ellas los tópicos que nos resultaban más relevantes para nuestros objetivos.

No está en el espíritu de esta investigación indagar sobre el nivel de consenso $\mathrm{u}$ homogeneidad ideológica presentes al interior de las formaciones. Ya hemos versado sobre esta cuestión en otra oportunidad (Moreno, 2002) y son varias las investigaciones que analizan la multiplicidad de sentidos que pueden encontrarse al interior de cada organización (Delamata, 2004; Delamata y Armesto, 2005; Bidaseca, 2004; Ferraudi Curto, 2006; Colectivo Situaciones, 2001; entre otros). De todas formas creemos que se puede arribar a una caracterización político-ideológica relativamente precisa de las formaciones a partir del discurso de sus máximos dirigentes. En tanto abordaje que concibe a las organizaciones como sujetos políticos resulta razonable "dar centralidad a las voces de los referentes políticos de las organizaciones por sobre las de los otros miembros" (D’Amico y Pinedo, 2008:2).

Repetimos que esto no quiere decir que supongamos que todos los militantes que pertenecen a tal formación política compartan los mismos pareceres políticos e ideológicos, ni que la identidad de la organización no esté también sujeta "a los significados alcanzados en la participación individual y colectiva, en sus distintas formas" (Delamata y Armesto, 2005:108), pero sostenemos que a través del discurso de los dirigentes podemos arribar con un alto nivel de precisión a los principales lineamientos políticos-ideológicos con que cada organización se define políticamente. Como señala Armelino (2004), más allá de la multiplicidad de actores y procesos que actúan en la definición de la identidad política de la organización, "es desde esos espacios de gravitación a nivel organizativo y de proyección política [los espacios

estructuras proposicionales, su sintaxis y el orden en el que aparecen actores y acciones; el análisis de la importancia y la relevancia con la que aparecen retratados determinados tópicos; los juegos de implicación y presuposición presentes en las proposiciones; los diversos niveles de descripción y abstracción registrados entre los distintos actores; y otros juegos semánticos que nos aporten para una mejor caracterización y comprensión de los rasgos ideológicos identitarios y sus posibles implicancias respecto a la problemática de la articulación política. (2008:222-253) 
dirigenciales] que se plantean las estrategias y se toman las decisiones para influir en el espacio público-político".(2004:4) Es útil en este sentido la definición de Van Dijk (2008) que destaca el modo en que el discurso de el/los dirigente/s -el modelo-, encarna, en tanto líder/es, los lineamientos ideológicos y políticos principales en torno de los cuales se configura la identidad política -las actitudes- de la organización.

La segunda fuente de datos que decidimos utilizar para este trabajo es la de las publicaciones y manifestaciones públicas de las propias organizaciones. En efecto, cada una de las formaciones consideradas publica -a través de medios gráficos 0 virtuales- sus pronunciamientos respecto a variados temas y problemas, argumentando y justificando sus diferentes acciones políticas. Consideramos que en dichas publicaciones aparece un discurso que -en tanto resultado de una elaboración previa entre los integrantes de la organización- resulta lo más cercano a un "discurso de la organización", es decir representativo de su identidad política. A diferencia de las entrevistas personalizadas a informantes clave, estas fuentes no cuentan con la espontaneidad -y en cierta medida, la "transparencia"- de aquellas, pero sí pueden aportar elementos a través de debates y planteos teóricos y políticos que no pueden ser abarcados en las entrevistas.

Una tercera fuente de información que vale la pena mencionar es el trabajo de Federico Shinzato y Norberto Zanzioth Las izquierdas en la política argentina (2007), que consta de un conjunto de entrevistas en profundidad a altos referentes de algunas de las principales organizaciones de lo que aquí denominamos el campo popular argentino. Tales entrevistas recorren temas de actualidad, definiciones y posicionamientos que mucho tienen que ver con los intereses de esta investigación. En concreto, tres de las ocho organizaciones que forman nuestra muestra son exploradas en dicho libro, por tanto se trata de una fuente de información secundaria que aporta valiosa información para nuestro trabajo.

Creemos que la conjugación de las fuentes mencionadas nos permitirá obtener grados satisfactorios de información relacionados a nuestra investigación, permitiéndonos acceder de modo claro a los principales lineamientos que configuran el perfil político-ideológico de las formaciones en cuestión. Mientras que las publicaciones nos brindan una imagen completa y consensuada de las organizaciones, las entrevistas en profundidad otorgan una imagen más espontánea y menos tamizada, que nos permite llegar a información ausente en publicaciones. 


\section{Características de la muestra ${ }^{37}$}

Tanto el universo de lo que aquí consideramos el campo popular como el del movimiento piquetero aparecen integrados por una vasta cantidad de formaciones políticas. Nos parecía inviable e innecesario intentar abarcar al total de las formaciones para los fines que nos proponemos y recursos (de trabajo y tiempo) con los que contamos en esta investigación. Por esta razón decidimos seleccionar un pequeño número de estas formaciones en las que pudiéramos indagar en profundidad desde la perspectiva propuesta. Del mismo modo, como uno de los insumos que nos parecía más pertinente para este abordaje era el de las entrevistas en profundidad con los dirigentes, la accesibilidad a estos resultó un factor no desdeñable.

De acuerdo a los propósitos de la investigación, el principal criterio de representatividad que utilizamos en la selección de las formaciones fue el de las orientaciones político-ideológicas. De este modo intentamos abarcar un arco ideológico lo más heterogéneo posible a los fines de establecer comparaciones útiles en función del criterio señalado. En este sentido, es claro que nuestra búsqueda está alejada de un muestreo de tipo probabilístico, ya que no consideramos relevante en esta instancia de la investigación construir un tipo de muestra que nos permitiera establecer parámetros con grados de error y confianza precisos y predeterminados.

Por el contrario, el objetivo de nuestra muestra fue más bien incluir a organizaciones que tuvieran cierto reconocimiento -es decir, no incluir a aquellas de alcance y visibilidad estrictamente local/barrial- y que entre todas estuvieran representadas lo que a priori consideramos las grandes coordenadas políticoideológicas -las matrices- y algunas de sus variantes más sobresalientes: el marxismo (en sus variantes trotskistas, maoístas y guevaristas), el nacionalismo-popular (con variantes que hacen más peso en la izquierda nacional, en el peronismo y con el propio marxismo leninismo) y la llamada nueva izquierda -que aquí llamaremos izquierda heterodoxa- (que incluye una línea más cercana al autonomismo y otra al guevarismo).

Siguiendo estos criterios estaríamos en la órbita de lo que se denomina el muestreo por cuotas, el que si bien "tiene poco valor en términos de estimación, ya que no es posible a partir de él calcular error de estimación (...) resultan de utilidad en términos de inmersión del investigador en el tema" (Papua, 1970:82). En efecto, el muestreo por cuotas consta de la construcción de una serie de categorías a partir de variables conocidas y de relevancia para la investigación -en este caso se trata de las orientaciones político-ideológicas- para así extraer una serie de casos (cuotas) que

\footnotetext{
${ }^{37}$ Entendemos por muestra la "selección de un número limitado de unidades de entre una totalidad siguiendo determinadas reglas y con la finalidad de sentar enunciados sobre ese universo." (Mayntz, Holm y Hubner, [1975]1996:89)
} 
abarquen y representen satisfactoriamente cada una de las categorías diseñadas. Puede decirse que constituye "una técnica afín al muestreo aleatorio" sin que sea una "especie particular del mismo" (Mayntz, Holm y Hubner, [1975]1996:108). Un rasgo central en este sentido, es que es el entrevistador -en este caso se trata de la misma persona que el investigador- quien escoge los casos a entrevistar. Por último, cabe señalar, que "la inferencia de los valores del universo estudiado a partir de los resultados de la muestra por cuotas no se somete a ningún cálculo matemáticoestadístico, sino que es tan sólo una aseveración. Esta, no obstante es legítima puesto que es comprobable." (Mayntz, Holm y Hubner, [1975]1996:110).

Es decir, dentro del conjunto de las organizaciones consideradas visibles/representativas, distinguimos tres grandes categorías -y subcategorías a su interior- en función de la variable configuraciones o matrices político-ideológicas. Una vez definido aquello buscamos a los máximos referentes de un conjunto de organizaciones que pudieran "Ilenar" las categorías y subcategorías diseñadas. El resultado de estas búsquedas y la accesibilidad que presentó cada caso nos llevó a seleccionar las siguientes formaciones políticas y dirigentes:

> Martín Obregón, dirigente del Frente Popular "Darío Santillán" (FPDS)

> Roberto Baigorria, Coordinador Nacional de Barrios de Pie (Libres del Sur)

> Amancay Ardura, Coordinador Nacional de la Corriente Clasista y Combativa (CCC) vinculada al Partido Comunista Revolucionario (PCR)

> Juan Cruz Daffunchio, dirigente del Movimiento de Trabajadores Desocupados "Aníbal Verón" (MTD-AV)

> Fernando Esteche, dirigente de la Coordinadora de Trabajadores Desocupados "Aníbal Verón" (CTD-AV) vinculada al MPR-Quebracho

> Roberto Martino, principal dirigente del Movimiento "Teresa Rodríguez" (MTR)

$>$ Néstor Pitrola, principal dirigente del Polo Obrero (PO), dependiente del Partido Obrero

> Federico Martelli, Secretario General del Movimiento de Unidad Popular (MUP).

$\mathrm{Si}$ bien no desconocemos que están ausentes un gran número de organizaciones -unas más relevantes que otras- consideramos que a partir de las que hemos seleccionado para este trabajo podemos avanzar en comprender los procesos de articulación/fragmentación del campo popular de acuerdo a los objetivos que nos propusimos desarrollar en esta investigación. 


\section{SEGUNDA PARTE: ANÁLISIS DE LAS FORMACIONES POLÍTICAS}

\section{BREVE PRESENTACIÓN DE LAS ORGANIZACIONES}

\subsection{Polo Obrero (Partido Obrero)}

El Polo Obrero es una fuerza orientada a la organización de trabajadores desocupados creada en diciembre del año 2000 a partir de la iniciativa -y bajo la órbita- del Partido Obrero. A su vez, el Partido Obrero es una fuerza política que nace en 1964, como una corriente de la izquierda argentina que se define como marxistaleninista-trotskista. Desde su fundación hasta 1983 se organizan bajo el nombre de Palabra Obrera, título de la publicación a partir de la cual surge el grupo.

Sus posiciones políticas se centraron en la "construcción de un partido genuinamente obrero", en oposición a tendencias que surgían en la militancia de la izquierda y del movimiento obrero que se apartaban de determinados tópicos como el "clasismo".

El Partido Obrero llega a la actualidad como una fuerza política reconocida dentro del espacio de la izquierda, con una sostenida presencia en los procesos electorales y en diversos escenarios de protesta. En política es un claro opositor del gobierno kirchnerista -tanto de la presidencia de Néstor Kirchner como de la de su esposa Cristina Fernández- en tanto es visto como representante de los intereses de los grandes capitales.

Para conocer la postura y lineamientos del Polo Obrero -y por extensión del Partido Obrero- nos entrevistamos con Néstor Pitrola, principal dirigente del Polo Obrero y uno de los máximos referentes del partido, sumado a material publicado por la organización, a la vez que tomaremos declaraciones de Pablo Rieznik, destacado dirigente del Partido Obrero, entrevistado en otro trabajo (Shinzato y Zanzioth, 2007).

\subsection{Corriente Clasista y Combativa (Partido Comunista Revolucionario)}

La Corriente Clasista y Combativa (CCC) es una organización que se conforma en el marco de la estrategia política del Partido Comunista Revolucionario (PCR) en el año 1994, buscando dar entidad y organización a diferentes elementos del mundo del trabajo, tanto ocupados, desocupados, como jubilados. Uno de sus referentes más significativos en el inicio fue Carlos Nolasco "Perro" Santillán, quien desde el Sindicato de Empleados y Obreros Estatales (SEOM) de Jujuy desarrolló un gran movimiento de base desde mediados de la década de 1990.

Más allá de los grados de autonomía que pueda mostrar en determinadas circunstancias la CCC respecto al PCR, es indiscutible que los lineamientos políticos e ideológicos de la CCC están fuertemente atravesados por los del PCR. EI PCR fue fundado el 6 de enero de 1968, a partir de una fuerte fractura con el Partido Comunista 
Argentino al que se le achacaba la traición de los verdaderos valores revolucionarios, el centralismo democrático, el revisionismo reformista, el oportunismo y otras cuestiones entendidas como claudicaciones de diversa índole.

Su postura política se enmarca en lo que ellos denominan el marxismoleninismo-maoismo, según el cual interpretan que la lucha revolucionaria en la Argentina debe basarse en dirigir al proletariado urbano, actor central y fundamental de la revolución, el que a la vez deberá contar con el campesinado pobre como aliado estratégico fundamental $\mathrm{y}$, circunstancialmente, también conformar alianzas con sectores de la burguesía nacional. Del mismo modo conciben el proceso revolucionario en diferentes etapas, partiendo de una revolución democrática-popular, agraria y antiimperialista, en marcha ininterrumpida al socialismo. (PCR, 2004)

Desde su fundación hasta la fecha, la Secretaría General del partido está en manos de Otto Vargas, mientras que el coordinador nacional de la CCC es Amancay Ardura, con quien tuvimos una entrevista en profundidad y de la cual extraeremos muchos elementos para nuestro análisis. También acudiremos al libro ya citado Las izquierdas en la política argentina... donde se incluye una entrevista a Vargas. Por último también incorporamos diferentes escritos del PCR y la CCC, entre los que se destaca el Programa del Partido Comunista Revolucionario de la Argentina (2004) donde se establecen los principales lineamientos políticos e ideológicos del partido, y por extensión de la organización.

\subsection{Movimiento de Unidad Popular (MUP)}

El Movimiento de Unidad Popular se funda en el año 1999, luego de un proceso de gestación que abarcó etapas diversas y posicionamientos políticos e ideológicos disímiles. El núcleo original proviene de la militancia en el ámbito estudiantil secundario y se inicia a principios de los ' 90 s al calor de la avanzada de las políticas de desregulación y libre mercado impulsadas por el gobierno de Menem. Así se llega a la fundación del AUCA ("Rebelde" en mapuche), una agrupación de orientación libertaria, asociada a la matriz ideológica del anarquismo.

Esta organización dirigida por jóvenes militantes va transitando diversas etapas y formas de militancia, con trabajo militante en gremios, barrios y universidades. La fuerte crisis de empleo de finales de los '90s conduce a privilegiar el trabajo en los barrios con los sectores desocupados en lo que será el movimiento piquetero. En esa etapa, entre agosto y septiembre de 2002 , se produce una primera fractura entre quienes optan por alinearse con los sectores de la CTA-FTV y del PCR-CCC y aquellos que se acercan al llamado Bloque Piquetero. Estos últimos pasan a formar el "MUP 20 de diciembre". 
Luego de que Kirchner asume la presidencia se produce una nueva tensión entre quienes se inclinan a apoyar al gobierno nacional y quienes se muestran recelosos de ello. En ese contexto se da un acercamiento entre funcionarios del gobierno nacional y la agrupación, principalmente encabezada por el dirigente kirchnerista Carlos Kunkel, quien los convoca a sumarse al proyecto político que impulsa el presidente Kirchner. Por ese entonces, el MUP pasa a formar parte del Frente Popular Darío Santillán (FPDS) y allí se instala el debate -al interior del MUP y al interior del FPDS- sobre qué postura tomar respecto al gobierno nacional. Finalmente, el núcleo que hoy constituye el MUP termina aceptando el ofrecimiento de los funcionarios del gobierno, se aleja del FPDS - grupos del MUP original optan por continuar al interior del FPDS- y pasa a formar parte activa del proyecto político del kirchnerismo.

Para desarrollar nuestro trabajo e indagar en los principales rasgos políticos e ideológicos que configuran la identidad política de la organización analizaremos una entrevista en profundidad realizada a Federico Martelli -secretario general de la organización-, algunos números de la "Revista 2010", elaborada por la organización, como así también comunicados y documentos, algunos de los cuales encontramos en el sitio web del movimiento: www.mupargentina.com.ar.

\subsection{Frente Popular Darío Santillán (FPDS)}

El FPDS es a la vez el resultado de un proceso de articulación y de fragmentación. Articulación por que se registra en su historia la búsqueda de espacios y organizaciones afines con las cuales ir sumando a la construcción política y acumular fuerzas y poder político con objetivos de transformación social. En este sentido el FPDS no tiene una historia, sino varias, las de cada una de las distintas organizaciones que lo terminan conformando. Entre los principales sectores que lo fundan podemos mencionar al llamado Núcleo Afinidad -un grupo de MTD que integraban el MTD Aníbal Verón- y el MUP. ${ }^{38}$

Era una especie de operativo ambulancia el que hicimos. Fuimos juntando pedazos de organizaciones que habian quedado partidas y que coincidíamos en 4 o 5 puntos. (Obregón, 2006)

En efecto se trataba de un "operativo ambulancia", porque como decíamos la articulación que termina conformando el FPDS es a partir de la fragmentación, de la búsqueda de conformar una coordinadora de organizaciones ante el duro golpe que significa la fractura del MTD Aníbal Verón, del que se desprende el mencionado

\footnotetext{
${ }^{38}$ El llamado Núcleo Afinidad incluía 7 MTD que formaban parte del MTD-AV: La Plata, Berisso, Lanús, Brown, José C. Paz, Lugano y San Telmo. Otras organizaciones que se mencionan como fundantes del frente -por fuera del Núcleo Afinidad- son el MTD La Verdad, la UTL, el MTD Resistir y Vencer 26 de Junio. También se menciona al MTR, pero no es claro si llegan a formar parte del espacio.
} 
Núcleo Afinidad y que resulta el principal impulsor del frente. La fractura del MTD Aníbal Verón se empieza a vislumbrar desde diciembre de 2003, a partir del distanciamiento entre el Núcleo Afinidad y el sector liderado por Juan Cruz Daffunchio. Desde principios del 2004 ambos grupos comienzan a diferenciarse actuando políticamente de manera separada, distanciamiento que mucho tiene que ver con las distintas caracterizaciones respecto del gobierno de Kirchner. Finalmente el 30 de noviembre se lleva a cabo el primer plenario del FPDS.

Para explorar el discurso del FPDS nos centraremos en el análisis de una entrevista en profundidad a Martín Obregón, un referente destacado de la organización, realizada en diciembre de 2006. Cabe señalar que resulta más complejo encontrar una voz que sintetice el pensamiento del FPDS por las características propias de su estructura, claramente diferente a la de los partidos tradicionales y de las organizaciones más homogéneas. Intentaremos suplir esta dificultad analizando a su vez artículos y declaraciones de la organización, muchos de ellos presentes en el sitio www.frentedariosantillan.org .

\subsection{MPR-Quebracho}

El Movimiento Patriótico Revolucionario QUEBRACHO (MPR-QB) se constituye como organización política el 31 de agosto de 1996, resultado de la confluencia de una serie de organizaciones, de diferentes vertientes ideológicas, pero muy marcada por la participación e influencia de ex militantes del PRT-ERP y Montoneros en los años '70s. Se trató de la confluencia de una serie de grupos -algunos de los referentes más importantes militaron en las filas del conocido Partido Intransigente- que hacia mediados de la década de 1990 optó por fundar una organización "de resistencia" en pleno auge neoliberal en el país y en América Latina. Al interior del movimiento piquetero, se destaca como la principal referencia política de la Coordinadora de Trabajadores Desocupados "Aníbal Verón”.

Hay dos grandes rasgos que podemos mencionar para presentar esta organización, uno vinculado a su posicionamiento político-ideológico y el otro asociado a su practica política. Respecto a lo primero, el MPR-QB se define desde un fuerte componente nacional que ellos mencionan como patriotismo revolucionario. El segundo aspecto obedece a una práctica fuertemente insurreccionalista, práctica constante en los distintos momentos políticos por los que atraviesa la organización.

Para analizar los aspectos que interesan sobre esta organización trabajaremos sobre diversas fuentes. En primer lugar, sobre una entrevista en profundidad realizada para esta investigación a Fernando Esteche, uno de sus dirigentes más sobresalientes. Del mismo modo extraeremos algunos elementos de la entrevista 
realizada al propio Esteche que figura en el trabajo ya citado Las izquierdas en la Argentina. Por último indagaremos en el libro realizado por la propia organización llamado "Habla Quebracho", publicado en diciembre de 2005 (Rubio y Del Grosso, 2005)

\subsection{MTD - Aníbal Verón}

EI MTD Aníbal Verón (MTD-AV) es una organización que formalmente se constituye a mediados de 2002, pero que recorre la historia de una diversidad de pequeños movimientos territoriales de desocupados, principalmente del sur del Gran Buenos Aires desde mediados de los '90s. Tiene un fuerte ascendente en el MTD Teresa Rodríguez, nacido entre 1997 y 1998, del que a principios de 1999 se separa el grupo que luego conformará el MTD de Florencio Varela, uno de los principales MTD de lo que será MTD-AV.

Es una organización compleja y heterogénea que resulta del intento permanente de articular experiencias territoriales autónomas en una instancia ordenadora que las supere. Las rivalidades territoriales adquirieron aquí una centralidad significativa, en tanto carecía de un polo o eje ordenador. Todos los MTD estaban en igualdad de condiciones -al menos en la formalidad- a la hora de decidir qué camino seguir.

Decíamos que formalmente se constituye en junio de 2002, luego de los asesinatos de Kosteki y Santillán, que desembocan en la fractura de lo que hasta ese entonces se denominaba la Coordinadora Aníbal Verón, en la que militaban los jóvenes asesinados y que había sido creada luego de las Asambleas Nacionales de Desocupados de La Matanza (julio y septiembre de 2001) agrupando a los MTD del sur del Gran Buenos Aires y a la Coordinadora de Trabajadores de Desocupados Aníbal Verón (CTD-AV) liderada por el MPR-QB. Hacia el 2004, el momento de máxima expansión, el MTD-AV estaba conformado por 14 MTD territoriales: Lanús, Alte. Brown, J.C. Paz, Fcio. Varela, La Plata, Berisso, Quilmes, Esteban Etcheverría, Claypole, Ezeiza, Cipoletti (Río Negro) y los de la ciudad de Buenos Aires: Lugano, San Telmo y Parque Patricios.

Respecto a esta organización nos encontramos con similares dificultades a las que las señalamos respecto al FPDS, en tanto resulta complejo encontrar una sola referencia que "hable en representación de la organización". De los referentes del MTD-AV, es seguramente Juan Cruz Daffunchio (dirigente del MTD de Fcio. Varela) el más conocido y representativo de la organización. Pudimos desarrollar una entrevista en profundidad con Daffunchio, que será el punto central desde el cual desplegaremos el análisis de esta organización. Al igual que en los casos anteriores, buscaremos 
otros documentos que complementen la información de la entrevista, aunque en este caso no contamos con una publicación impresa o digital que hable en representación de la organización.

\subsection{Movimiento Teresa Rodríguez}

A mediados de 1996, se comienza a gestar un movimiento que agrupaba desocupados y empezaba a realizar una serie de movilizaciones en el distrito de Florencio Varela, que simplemente se llamaba Movimiento de Trabajadores Desocupados (MTD). Luego del asesinato de Teresa Rodríguez en los cortes de Cutral Co, el 12 de abril de 1997, el MTD adopta el nombre MTD-Teresa Rodríguez, que luego pasará a llamarse Movimiento Teresa Rodríguez (MTR).

EI MTR es una organización de desocupados con epicentro en Florencio Varela, pero se compone en sus orígenes de la articulación de diferentes experiencias territoriales, básicamente de Mar del Plata, Hurlingham y San Francisco Solano. Constituye el resultado de un grupo de militantes que en la búsqueda de construcción política visualizan a la organización de los trabajadores desocupados como el punto de partida. EI MTR constituye una de las experiencias pioneras como organización política de desocupados de la que se han desprendido diversos grupos, entre los cuales se destacan el MTD de Varela y el MTD de Solano que luego serán puntales especialmente el primero- de la conformación del MTD-AV.

Roberto Martino, principal referente de la organización, tiene como antecedente político su militancia en el Partido Revolucionario de los Trabajadores (PRT) durante la década de los '70s, que de uno u otro modo delinea el perfil político e ideológico de la organización. Con él nos entrevistamos el 13 de septiembre de 2007 en el local de la organización y pudimos conversar en profundidad sobre los principales temas que se pretenden abordar en este trabajo. Indagaremos en dicha entrevista y en la publicación "Todo o nada" elaborada por la propia organización para intentar dar respuesta a los interrogantes de nuestro trabajo.

\subsection{Barrios de Pie (Libres del Sur)}

El Movimiento Barrios de Pie (MBP) es una organización de carácter principalmente territorial que nace en diciembre de 2001, como parte de la estrategia de Patria Libre (PL), la formación política de la que depende la organización, que desde el 2006, y junto con otras organizaciones menores ${ }^{39}$, fundan y pasan a llamarse

\footnotetext{
${ }^{39}$ Además de Patria Libre y Barrios de Pie, fundaron el Movimiento Libres del Sur Jorge Pereyra (Partido Comunista Congreso Extraordinario), Jorge "Quito" Aragon (Agrupación Martin Fierro), Cecilia Merchan (Red de Mujeres Solidarias), Nahuel Beibe (Frente Barrial 19 de diciembre) y Marcelo "Nono" Fondizi (Agrupación Envar el Kadri), entre otros dirigentes.
} 
Movimiento Libres del Sur (MLS). Para trazar en pocas líneas algunos de los elementos más significativos de la organización, interesa rastrear los orígenes de Patria Libre, principal antecedente, tanto de Barrios de Pie, como del propio que Movimiento Libres del Sur.

Patria Libre se funda en el 1987, con su núcleo principal en la provincia de Córdoba y surge como una escisión del Partido Intransigente (PI). Los principales dirigentes contaban con una militancia en la década de los '70s, tanto en Montoneros como en el PRT-ERP, a los que se sumaron militantes de otras generaciones, algunos de origen católico (hay varias figuras de la Democracia Cristiana que tuvieron roles relevantes) que hacían sus primeras experiencias militantes en contra de la Guerra de Malvinas y en el contexto de la vuelta a la democracia en 1983. A mediados de la década de 1980, la dirigencia del PI busca un acercamiento con el PJ, que es resistido por un sector que se autodenomina Intransigentes por el Frente. Es de este grupo interno del PI que se desprende el núcleo que va a fundar Patria Libre.

Patria Libre se conforma como una formación política de la izquierda nacional y comienza sus pasos con un acercamiento con diferentes formaciones de izquierda, desde el Movimiento Al Socialismo (MAS) hasta el Partido Comunista. En la primera mitad de la década del `90, desarrollan diversas experiencias de construcción política en barrios y otras orientadas hacia la juventud. Hacia el final de la década se acercan y forman parte de la Central de Trabajadores Argentinos (CTA) y en el año 2000 forman parte de la experiencia política del Polo Social que encabezaba el cura Luis Farinello. A partir del 2001 se crea el Movimiento Barrios de Pie, que tiene un papel relevante al interior del conglomerado de organizaciones de desocupados, participando de la Asamblea Nacional Piquetera celebrada en la Matanza en julio de 2001 -todavía con el nombre Patria Libre. Finalmente, a partir del 2003, se acercan al proyecto político que encabeza el presidente Néstor Kirchner.

Para rastrear los temas que nos resultan significativos para nuestro trabajo, analizaremos una entrevista en profundidad que pudimos realizarle a Roberto Baigorria Coordinador Nacional del Movimiento Barrios de Pie en septiembre de 2007. Simultáneamente consultaremos diversos materiales que nos aporten información para nuestro trabajo, entre ellos las páginas web www.barriosdepie.org.ar y www.libresdelsur.org.ar 


\section{AUTODEFINICIÓN IDEOLÓGICA GENERAL}

En este apartado buscamos explorar el modo en que se definen ideológicamente las diferentes formaciones políticas. Decimos que se trata de autodefinición "general", en tanto en que no nos ponemos a explorar tópicos específicos, los que serán analizados de forma separada, tales como visiones sobre el Estado, sobre la cuestión nacional, el clasismo, etc. Nos interesa aquí comenzar a delinear los diferentes posicionamientos que cada organización establece en el plano ideológico.

\subsection{Polo Obrero (Partido Obrero)}

El PO se define antes que nada como una organización "marxista-leninistatrotskista". De esta manera se busca adscribir a los componentes teóricos del marxismo, haciendo especial hincapié en la lucha de clases, en el enfrentamiento ineludible entre burgueses y proletarios y en el protagonismo de la clase obrera como actor central de la lucha política que se propone llevar a cabo:

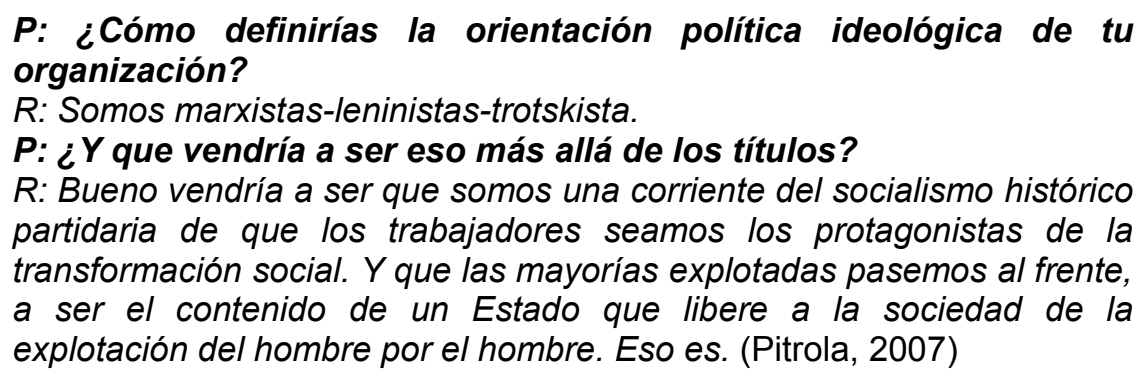

Como se desprende de estas palabras de Pitrola, la concepción ideológica está fuertemente orientada a una lucha en contra del capitalismo tal como la presentaba el propio Marx. El modo de producción capitalista es portador de una lógica de "explotación del hombre por el hombre" que debe ser erradicada. La lucha de los trabajadores debe ser orientada a terminar con dicho sistema de explotación. La sociedad está atravesada por un conflicto central que determina el resto de las dimensiones de lo social y divide a la sociedad en explotadores y explotados. No se contempla la posibilidad de mejorar la situación de los trabajadores a partir de salarios o condiciones laborales más satisfactorias para los trabajadores si eso no se orienta a la abolición del sistema capitalista.

Uno de los rasgos distintivos de su autodefinición ideológica radica en la centralidad de la "clase obrera" como actor central en la disputa política. El objetivo del partido es la construcción de un "partido genuinamente obrero" que represente, en el plano político, la contradicción fundamental del capitalismo desde la perspectiva marxista entre burguesía y proletariado. De este modo, la dimensión política debería 
"reflejar", la contradicción entre el capital y el trabajo que se desarrolla en la dimensión económica. Pablo Rieznik, dirigente del PO, señala:

El PO lucha por una alternativa obrera y socialista. Obrera porque designa de ese modo a la clase que es capaz de realizar los cambios revolucionarios que esa transformación requiere; y socialista porque designa el cometido de la abolición de la explotación del hombre por el hombre y la instauración de una asociación fraternal entre ellos. (Shinzato y Zanzioth,2007:46)

La clase obrera aparece revestida de una capacidad de transformación social distintiva, que la distingue de otros grupos sociales. Simultáneamente el cuerpo social aparece atravesado por la contradicción capital-trabajo y constituido por las clases sociales que representan dicha contradicción. Es decir se parte a la sociedad en dos grupos fundamentales que están oposición y la disputa política gira en torno al triunfo de uno de ellos.

Respecto al carácter trotskista se destaca la postura genuinamente revolucionaria de Trotsky en tanto representante de los verdaderos valores de la revolución de octubre que fueron traicionados por la degeneración stalinista. Esta degeneración está asociada a los lineamientos del "socialismo en un solo país" y a la "coexistencia pacífica", como claudicaciones del proceso revolucionario ruso en manos de Stalin. Esto se vincula con el papel del Partido Comunista y el Partido Socialista en tanto estuvieron fuertemente influidos por estas tendencias, lo que los llevó a apoyar diversas "variantes de la burguesía nacional". Por contraste, el trotskismo aparece como la contracara del stalinismo, despojado de sus vicios, errores y contradicciones, erigiéndose como la "fiel representación de los intereses de la clase obrera", en oposición a las "desviaciones" de las otras posturas que traicionan dicha representación.

Nos permitimos citar un largo fragmento de la entrevista realizada a Pitrola en tanto nos brinda una acabada visión de los principales elementos de la autodefinición ideológica:

P: ¿La pata trotskista qué es lo que le agrega? ¿En qué difiere un marxista leninista de un trotskista?

$R:$ Y el eje en la oposición a la degeneración stalinista. Porque la caída del muro de Berlín no ha sido gratis ni casual. Es un proceso que se degeneró por dentro. Y que no empezó en 1991, sino que empezó con la degeneración del stalinismo, con el planteo del socialismo en un solo país y no de la extensión mundial de la transformación socialista. Con el planteo del statu quo con el imperialismo. La llamada coexistencia pacífica, que después se tradujo en todo el período de la guerra fría. $Y$ particularmente, lo que hemos sufrido, y acá en la Argentina lo hemos vivido trágicamente, que fue la orientación de apoyo a diversas variantes de la burguesía nacional, que el stalinismo impuso como orientación de los partidos de la clase obrera que fueron muy fuertes después de la revolución del 17. (...) 
Hoy, los que resistimos el pacto social, los que preparamos la lucha con él, estamos claramente inscriptos a través del Partido Obrero y también de todo un activismo de lucha importante que hay en la Argentina, inscriptos en una perspectiva mucho más radical, de independencia de clase, respecto del nacionalismo y de cualquier otra variante del imperialismo. (...)

Esta es la significación concreta que tiene hoy el trotskismo, defender, frente a esa idea de que la clase obrera tiene que ir de furgón de cola de un movimiento nacional como etapa previa a la lucha por el socialismo o por un estado de la clase obrera, cómo es un mismo proceso ininterrumpido que tiene que poner a los trabajadores al frente. (Pitrola, 2007)

De esta manera se resalta la complicidad del stalinismo con el imperialismo y, a la vez, del nacionalismo (burgués) con el imperialismo. El elemento central remite a la "independencia de clase" y la necesidad de que la clase obrera "encabece" un proceso de transformación que no se desvíe hacia un "movimiento nacional". La lucha en contra del capitalismo y en contra del imperialismo constituyen un "mismo proceso ininterrumpido". Cualquier construcción política que no contemple estas cuestiones, que no le otorgue a la "clase trabajadora" -la que es representada por el Partido Obrero y por "todo un activismo de lucha importante que hay en la Argentina"- ese lugar central, es descartada de plano.

\subsection{Corriente Clasista y Combativa (PCR)}

Las definiciones ideológicas de la CCC reproducen, desde otro lugar y desde otra práctica, los principales lineamientos del PCR, principal impulsor y responsable de su surgimiento y existencia. Por esto, no creemos relevante para nuestra investigación centrarnos en señalar las diferencias que pudiera llegar a haber entre una u otra, por lo que observaremos algunas definiciones del PCR que nos resultan claras y útiles para una caracterización ideológica de la organización. Esta aclaración vale para los distintos tópicos que analizaremos en este trabajo.

En líneas generales, el PCR se define como una organización marxistaleninista-maoísta. En este sentido abogan por una estrategia política centrada en una revolución encabezada por el proletariado urbano y teniendo como principal aliado al campesinado pobre y, eventualmente, algunos sectores de la burguesía nacional. Conciben una primera etapa democrático-popular, agraria y antiimperialista, en "camino hacia el socialismo", planteando como objetivo concreto la dictadura del proletariado. Nos permitimos citar un fragmento del Programa del PCR de la Argentina en donde se definen estas cuestiones:

El Partido Comunista Revolucionario de la Argentina es el partido político revolucionario del proletariado, la forma superior de su organización de clase. Es su destacamento de vanguardia, el destacamento nacional de una clase que es internacional, integrado por 
los mejores hijos de la clase obrera y el pueblo. Se asienta fundamentalmente en el proletariado industrial y su misión es dirigir al proletariado y las masas populares en la lucha revolucionaria contra sus enemigos: el imperialismo, los terratenientes y la burguesía intermediaria, con el objetivo de conquistar el poder para realizar la revolución democrática-popular, agraria y antiimperialista en marcha ininterrumpida al socialismo. Abriendo así el camino a nuestra meta final, la sociedad sin explotadores ni explotados: el comunismo. La teoría que guía su acción es la teoría revolucionaria del proletariado: el marxismo-leninismo-maoísmo. (PCR, 2004)

Es decir, se destacan los siguientes elementos de la presentación ideológica de la organización: el clasismo, el partido como vanguardia ("forma superior de su organización de clase”), la centralidad de lo agrario y el carácter antiimperialista de la revolución. Se desprenden de estas sentencias una concepción etapista del proceso revolucionario en tanto se habla de un momento "democrático-popular, agrarista y antiimperialista" en tránsito hacia el socialismo. Se coloca al proletariado industrial como el actor central por excelencia, y se le agrega el papel del campesinado, el carácter agrario de la revolución. Por último, se busca hacer mención a la especificidad argentina, en tanto sujeta a la presión y explotación de los imperialismos. La cuestión de cómo encarar la llamada "cuestión nacional" es un tema central en la definición ideológica del partido sobre la que volveremos más adelante.

Estos tópicos centrales que se presentan en el programa -etapismo, agrarismo y antiimperialismo- son coincidentes con lo que nos comentaba Ardura cuando fue entrevistado:

\begin{abstract}
P: ¿Cómo se para la CCC? ¿Cómo se definen?
$R$ : Nosotros somos revolucionarios y acumulamos para la revolución agraria anti-imperialista. Una revolución que voltee los dos pilares: la estructura terrateniente de Argentina y la dependencia. Que independice el país y que termine con el latifundio. Primer paso de la revolución. (...) Porque nosotros proponemos una revolución agraria y antiimperialista. Es decir, romper con la dependencia y con el latifundio. Es una tarea hoy. Por supuesto que aspiramos caminar al socialismo. Pero tenemos que voltear la montaña de... Hay que unir la mayoría contra la minoría y achicar el blanco todo lo que más puedas. (Ardura, 2007)
\end{abstract}

\title{
2.3. Movimiento de Unidad Popular
}

De acuerdo a lo que veíamos en la presentación de la organización, el MUP ha atravesado diferentes etapas marcadas por distintos posicionamientos políticos e ideológicos. Siguiendo lo que nos decía Martelli, esta cuestión obedece a cuestiones de edad, generacionales, y a los diversos contextos de los cuales derivan diferentes análisis e interpretaciones de las cosas. De esta manera, el núcleo que hoy conforma el MUP -más allá de los fraccionamientos y desprendimientos- transitó un camino desde posturas libertarias cercanas al anarquismo hasta posicionamientos nacionalpopulares fuertemente vinculados al peronismo. Si bien en la actualidad es la segunda 
opción la que claramente predomina, aún se mantienen vestigios de los lineamientos originales, los que aparecen -si se nos permite- reciclados y articulados en la matriz nacional-popular.

\begin{abstract}
$P: ¿ C o ́ m o$ definís la orientación político-ideológica de tu organización?

$R$ : Nosotros somos del pensamiento nacional, popular, revolucionario y libertario. Nosotros nos basamos en la historia de la Argentina. Nos parece que el anarquismo y el peronismo han sido las ideologías mayoritarias de la clase obrera en distintas etapas. Que tienen mucho que ver. Siempre hemos planteado la equidistancia tanto de un imperio como de otro. Hemos planteado la necesidad de un desarrollo de la Argentina basada en la capacidad política de su clase trabajadora. Me parece que es algo que hoy en día nos hace falta retomar. La visión de la centralidad de los trabajadores en un proyecto nacional. Me parece que desde el golpe del 55 a esta parte, lo que ha logrado la oligarquía es correr al movimiento obrero del peronismo y del campo nacional. Me parece que es una búsqueda constante y que no hay una receta. Una búsqueda del equilibrio entre el rol del Estado y la necesidad de la organización social por sobre el individuo y a la vez el respeto a las libertades individuales. Me parece que eso es lo que plantea Perón con mucha claridad. La búsqueda de la realización del individuo dentro de la comunidad organizada. Eso también es mucho de lo que han concebido los libertarios. No la búsqueda ni del Estado totalizante soviético ni el liberalismo individualista del capitalismo. (Martelli, 2007)
\end{abstract}

Como puede verse en esta extensa cita, el MUP se presenta conjugando la matriz nacional-popular con componentes libertarios del anarquismo, trazando un paralelismo entre ambos a partir de dos niveles: por un lado plantea que ambas ideologías fueron las que mayor arraigo tuvieron en la clase trabajadora argentina en diferentes momentos de su historia; por el otro lado se vincula la idea de comunidad organizada de Perón -la que es interpretada como la búsqueda del equilibrio entre el Estado, las organizaciones sociales y el individuo- con las ideas libertarias que versaban sobre lo mismo. Sin dudas, más allá del intento de recuperar algunos elementos del anarquismo, el MUP se posiciona política e ideológicamente al interior de la matriz nacional-popular, cuyos rasgos principales podríamos resumirlos en la búsqueda del desarrollo nacional (con una burguesía nacional independiente de las potencias imperialistas) incorporando a la clase trabajadora mediante el desarrollo de la industria, el mercado interno, el pleno empleo y un modelo de Estado de Bienestar e interventor que garantice todo ello.

En contraste con las definiciones de corte marxista, la autodefinición ideológica del MUP no remite a definiciones demasiado precisas o acabadas acerca del camino a seguir y las características finales de a donde se quiere llegar, sino más bien que se establece una suerte de horizonte hacia el cual ir yendo. Es decir, no hay una definición concreta sobre la necesidad ineludible de terminar con la propiedad privada de los medios de producción, de desarrollar el partido de vanguardia de la clase 
trabajadora, de establecer una dictadura del proletariado o conformar milicias populares y promover la insurrección armada. En su página web señalan que su organización "busca ser parte de la experiencia política, social y gremial del sector del trabajo y la juventud que lucha por la plena vigencia de los derechos sociales, políticos, económicos y culturales." (MUP, 2008)

Sin objetivos maximalistas ni acabados, la línea y definición que presentan al público se enmarca en la lógica de avanzar hacia una sociedad menos excluyente, apoyar a aquellos sectores que, entre el universo de las formaciones políticas concretas, represente los intereses más beneficiosos para las mayorías y tenga la capacidad y las posibilidades reales de llevarlo adelante. Las valoraciones positivas respecto al peronismo descansan sobre la idea de que es posible avanzar hacia una sociedad más equitativa a partir de un Estado interventor y social que regule los agentes económicos en beneficio de los sectores más desprotegidos. En este marco no se lo responsabiliza directamente al Estado y al gobierno de los males que aquejan a la sociedad, como si este fuera un representante y garante directo -y necesario- de las clases dominantes. La disputa política central que atraviesa a la sociedad argentina en la actualidad no es, para ellos, la del comunismo vs. capitalismo, si no la del Proyecto Nacional vs. el Proyecto Liberal.

\subsection{Frente Popular Darío Santillán}

El FPDS reniega de las etiquetas ideológicas que suelen usar otras organizaciones. Esto obedece -señalan- a que el frente es el resultado de un proceso de articulación, de una síntesis política a partir de perfiles ideológicos distintos. La síntesis se logra a partir de los puntos comunes que subyacen a aquellas diferencias, tales como el "antiimperialismo, el anticapitalismo y la construcción del poder popular" (FPDS, 2007). Desde estas coincidencias se avanza en definir una serie de lineamientos, que permiten definir una identidad común. Así aparecen distintos tópicos, puntos nodales, que condensan los principales rasgos de la identidad política que presenta la organización.

En primer lugar se menciona la definición de popular que remite a la necesidad de superar la clásica visión marxista-leninista que centraba las expectativas revolucionarias en el sujeto clase obrera. Desde su punto de vista, las grandes transformaciones que ha sufrido el capitalismo en los últimos años llevan a la necesidad de complejizar aquella visión obrerocéntrica, para lo cual las categorías de pueblo o lo popular resultan más adecuadas. En un sentido similar también se destaca el carácter multisectorial del frente, remitiendo a los distintos sectores y grupos sociales que conciben como sujetos políticos para su proyecto político. 
Otro rasgo importante sobre el que se centra la definición ideológica de la organización es la cuestión de la autonomía destacando que se definen "como autónomos del Estado, los partidos, las Iglesias y las Centrales sindicales" (FPDS, 2007). Pese a renegar de la etiqueta de autonomistas que muchos le adjudican, la cuestión de la autonomía -al menos la necesidad de enunciarla y definirla- está presente en su discurso. Un tema a tratar en la tercera parte es si la definición de autonomía presente en la organización no opera como un obstáculo para determinados procesos de articulación política.

En el marco de esta renuncia a adscribir a paradigmas ideológicos preconcebidos y preestablecidos, apelan a la enunciación de una serie de principios organizativos que funcionan como rasgos definitorios de su identidad política. Estos principios son la democracia de base ("el ejercicio democrático para la toma de decisiones. La ejecutamos en las asambleas que se realizan periódicamente en todos las agrupaciones de base, en los plenarios sectoriales (...) y en los plenarios nacionales"), la formación ("la reflexión colectiva sobre nuestra práctica, y la incorporación de conocimientos surgidas de otras experiencias de lucha emancipatorias"), la lucha ("no solo como la forma mas adecuada para exigir nuestras reivindicaciones y avanzar en la transformación de la sociedad, sino también como una parte constitutiva de nuestra formación política") y la autogestión ("como la libre decisión sobre el destino de recursos generados por nuestro propio trabajo, recibidos solidariamente, expropiados a empresas capitalistas o arrancados al Estado"). (FPDS, 2007).

Por último, y en consonancia con el modelo situacional, señalan la necesidad de concebir el cambio social desde una doble perspectiva, por un lado cotidiana, construyendo en el día a día, en las prácticas políticas, el tipo de sociedad al que quieren arribar y, por otro lado, como objetivo en el tiempo, al que denominan como socialismo "asimilándolo a la idea de crear una sociedad sin explotadores, pero acordando que serán los propios pueblos que protagonicen esos cambios quienes darán contenidos a esas ideas" (FPDS, 2007).

Una apretada síntesis de estas definiciones nos la daba Obregón cuando definía la orientación ideológica del frente de la siguiente manera:

\footnotetext{
P: ¿Cómo definirías la orientación político-ideológica que posee tu organización?

R: El frente es una organización que a partir de algunos principios organizativos básicos... La democracia de base, es un poco uno de los pilares de la construcción del frente. ¿Qué quiere decir esto? Básicamente, que los trazos gruesos de la política tienen que definirse en las asambleas de base. Hay una definición incluso que dice que son los trabajadores los que marcan la orientación política de la organización, ya sean ocupados o desocupados. La democracia de
} 
base es un poco el pilar que sostiene toda la estructura. En función de eso y partir de la construcción de poder popular -que no es ni más ni menos que el hecho de ir generando niveles organizativos cada vez más altos a nivel de los sectores populares- pueda en algún momento disputar poder. Y, el planteo último, nosotros seguimos reivindicando la consigna del cambio social, vieja consigna de La Verón, que puede traducirse como una transformación revolucionaria de la sociedad. En algunas cartillas que tenemos, planteamos al cambio social en términos de una enorme redistribución de la riqueza, desde los sectores que hoy las concentran (empresarios, banqueros, terratenientes, etc.) hacia los trabajadores y el pueblo. (Obregón, 2006)

\subsection{MPR-Quebracho}

El MPR-QB se define como "una organización política que lucha por la liberación nacional y social de nuestra Patria. Por un país socialmente justo, económicamente independiente y políticamente soberano. Por la Revolución Nacional Antiimperialista" (Rubio y Del Grosso, 2005:19). Como su nombre lo indica se trata de una definición política en la que la cuestión nacional posee un lugar central, fuertemente emparentada con el peronismo histórico, al punto de asumir literalmente sus históricas banderas declamatorias. En este sentido es que señalan que la contradicción política central es la que se establece entre Patria y Entrega y no entre izquierda y derecha (o progresistas y reaccionarios), conceptos que desde la perspectiva de Esteche han perdido toda significación relevante. Acorde con su ascendiente en ex militantes de los '70s, también se recupera literalmente el objetivo de la "patria socialista". (Shinzato y Zanzioth, 2007:180).

Respecto a la cuestión de la Patria, su definición busca reivindicar "la fidelidad a nuestros orígenes, lo que es decir a nuestros pueblos, a nuestros idiomas, a nuestra historia, a nuestra tierra, a los trabajadores, que son quienes en definitiva, con su diario sacrificio, dan origen a todos los bienes y riquezas de la sociedad" (Rubio y Del Grosso, 2005:20). Desde estas definiciones, se observa una clara apelación a las cuestiones nacionales antiimperialistas como "la madre de las batallas", la contradicción política principal. Prefieren utilizar el término Patria antes que el de Nación, porque buscan darle un sentido regional, latinoamericano, orientado según la idea bolivariana de "Patria Grande".

Respecto al adjetivo de revolucionarios, hacen mención a "cambios profundos" a las verdaderas y auténticas transformaciones y a la necesidad de evitar caer en los cambios cosméticos que "cambian algo para no cambiar nada". La oposición revolución vs. reforma se reedita con claridad y fuerza en la definición de la organización.

Se pueden mencionar otras definiciones que resultan interesantes para una caracterización ideológica de la organización. En la entrevista brindada por Esteche al 
trabajo de Shinzato y Zanzioth (2007), aparecian dos rasgos ideológicos presentes en la identidad de la organización: el profundo historicismo y el marxismo-leninismo. Así lo decía:

"En cuanto al sustento ideológico de nuestra organización, además de estar penetrados por un profundo historicismo, porque creemos que si no se conoce la historia no se puede proyectar política, nos formamos en el marxismo-leninismo en cuanto a cosmovisión del mundo, categorías de análisis y filosofía política." (Shinzato y Zanzioth, 2007:180).

La cuestión histórica es un elemento recurrente que aparece presente en diferentes momentos del discurso de la organización, contextualizando el análisis de los diferentes procesos políticos. Así aparecen comentarios como "te estoy hablando de tiempos históricos, siglos, décadas" y aclaraciones por el estilo. Respecto al marxismo-leninismo es claro en relación a su concepción de revolución y su apelación al materialismo histórico y al socialismo como "objetivo último" de la organización (Shinzato y Zanzioth, 2007:198)

Por último, hay una explícita mención sobre el insurreccionalismo como rasgo definitorio de la organización. En todos los documentos y entrevistas con los que trabajamos hay una constante preocupación por fundamentar el frecuente uso de la violencia -entendida aquí en referencia a los disturbios, daños a empresas, comercios, entidades bancarias, enfrentamientos con la policía, etc- que hace la organización. Sin dudas, esta cuestión constituye un rasgo relevante en la identidad políticoideológica de la organización que se ve tanto en el accionar público, como en la constante aparición de dicho tópico en sus diferentes discursos.

Esteche insiste en señalar que lo que define a la identidad de la organización es su práctica política, más allá de las tradiciones ideológicas que confluyan allí; algo parecido a lo que veíamos en el FPDS. En esta lógica, la práctica política -donde el insurreccionalismo tiene un lugar central- se convierte en la referencia identitaria principal:

En el caso nuestro lo que define la identidad de Quebracho es la política. La política de QB es una política de unidad de los sectores patrióticos revolucionarios (...) Después la vocación de enfrentamiento, la vocación de protagonizar ese proceso político. ¿Enfrentamiento por que? Porque somos concientes de que hay un enemigo. No es que estamos peleando contra molinos de viento. (...) entonces hay que tener en claro que hay un enemigo, entonces los términos son de guerra.(...) Identidad de nuestra organización es eso, es la vocación de enfrentamiento a partir del reconocimiento de que tenemos un enemigo, o que tenemos enemigos. (Esteche, 2007)

\subsection{MTD - Aníbal Verón}


Volvemos a señalar que en el caso del MTD-AV resulta muy complejo definir ciertas cuestiones debido a la propia naturaleza de la organización por la que "pasaron prácticamente todas las corrientes: trotskistas, quebracho, los horizontalistas "Tony Negri", izquierda cerrada no trotskista, leninista, estilo puntero, ex PJ." (Daffunchio, 2007). Más allá de esto nos resulta interesante poder indagar sobre el pensamiento de Daffunchio, uno de los principales referentes de la organización, y que sin lugar a dudas tiene una fuerte gravitación en el rumbo de la organización.

La "definición de manual" de la organización es la que gira en torno de las tres consignas de "trabajo, dignidad y cambio social", planteada ya en los inicios del MTD Teresa Rodríguez. En este sentido Daffunchio destaca algunas discusiones al interior de la organización con sectores que insistían en la necesidad de explicitar la orientación político ideológica, mientras que su posición se inclinaba por mantener el discurso reivindicativo. Así relata este debate:

\begin{abstract}
Y me acuerdo que la discusión que había con otros sectores de izquierda era, -trotskistas, había muchos trotskistas como siempre-, que el programa del MTD debía plantear la cuestión del socialismo. Nosotros decíamos que no, que era un movimiento de masas reivindicativo, donde iban a participar radicales, peronistas, comunistas y anarquistas, y que además íbamos a ser minoría esos comunistas y anarquistas y que debiamos tener un programa acorde con las reivindicaciones de la gente, un movimiento social. Y que lo central eran estos planes sociales, que prácticamente todavía ni existían. (Daffunchio, 2007)
\end{abstract}

Cuando lo consultamos sobre la orientación ideológica resaltó su pertenencia a la izquierda, reivindicando al marxismo como lineamiento general, como cosmovisión política. Simultáneamente aparecen en el relato toda una serie de formulaciones que destacan los sucesivos cambios por los que fue atravesando; desde cierta ortodoxia hasta posiciones que, por contraste, podemos señalar como heterodoxas dentro del universo marxista. Es muy ilustrativo el siguiente párrafo en el que relata dicha cuestión:
Y en la búsqueda de esa masa, antes de llegar a ese pueblo, nos fuimos transformando en lo que nos fuimos transformando. Eso tuvo todo un recorrido que empezó con mucha ortodoxia y que la práctica, y un criterio crítico, y muchas internas, mucho desgaste, muchos golpes en realidad, te van acomodando un poco la cabeza. Hoy por hoy, uno quiere obviamente un cambio social, quiere una revolución, una democracia revolucionaria, pero está claro que con los esquemas ortodoxos y clásicos que tenemos, no podemos. (Daffunchio, 2007)

Un rasgo sobresaliente de la autodefinición ideológica de este referente tiene que ver con señalar la importancia del cambio, de la reformulación de consignas y, en el mismo sentido, de criticar fuertemente la inflexibilidad e intransigencia de aquellas posturas que, afincadas en cierto dogmatismo ortodoxo, no conciben la posibilidad de poner en discusión y revisión algunos de los supuestos sobre los que construyen su 
identidad política. El debate central es de qué manera pensar la política y qué relación debe tener con las definiciones ideológicas. Esto es ¿hasta qué punto conviene "cerrar" la identidad de una organización en un "enlatado" que restringe -en ocasiones, casi totalmente- el espacio de lo contingente? Estas cuestiones estaban en el debate entre avanzar en definiciones ideológicas -sobre si socialismo, comunismo, dictadura del proletariado, revolución, etc.- o promover "un movimiento de masas reivindicativo, donde iban a participar radicales, peronistas, comunistas y anarquistas, y que además íbamos a ser minoría" (Daffunchio, 2007).

Es muy recurrente esta separación entre las necesidades políticas y cuestiones que obedecen a definiciones ideológicas. Así explica que preferían aparecer como horizontalistas tanto para evitar una discusión al interior de la organización que podía desembocar en fragmentación, como por el hecho de que "era más aceptable para la clase media". Las críticas al dogmatismo y a la rigidez de ciertas posturas -él las llama troskismo, trosko-guevarismo y trosko-leninismo- son formuladas desde la valoración respecto a su efectividad política. Esto está presente claramente en el debate sobre el uso de pasamontañas y palos en los cortes, que fue el detonante de la ruptura con la CTD-AV, como así también en el debate sobre cortes con carril alternativo y acuerdos con comerciantes y vecinos de la zona. En todo momento se destaca la importancia de buscar consenso con otros sectores sociales -comerciantes, clase media, etc.- y se tiene en cuenta el impacto de las medidas respecto al resto de la sociedad.

Como señala en el fragmento recién citado, no se renuncia al cambio social, a la revolución, a la democracia revolucionaria, sino que se ponen en cuestión las formas de llegar o avanzar en esa dirección. Se critica a las posturas que "confunden método con ideología permanentemente" y se reconoce la incertidumbre y la contingencia de todo proceso político:

"no sabemos como va a terminar el proceso, pero apostémosle al triunfo. Y si termina en una cosa que no es socialismo, mientras no sea este capitalismo de mierda que tenemos..." (Daffunchio, 2007)

En resumen, podemos decir que la postura que propone Daffunchio está atravesada por la necesidad -dada por su interpretación de su propia experiencia- de flexibilizar ciertos principios ortodoxos comunes en la izquierda argentina. Sin renunciar al marxismo, identificándose con él, critica la rigidez de muchas organizaciones que subordinan la construcción política y la acumulación de poder a debates abstractos de corte ideológico, en una equivocada aplicación de la teoría a la realidad. Existen en su discurso recurrentes menciones a cambios en la forma de pensar las cosas, reformulaciones políticas e ideológicas, etc., que respaldan esta 
postura que declama la necesidad de rediscutir ciertos dogmas a la luz de su eficacia política.

\title{
2.7. Movimiento Teresa Rodríguez
}

La definición ideológica del MTR que nos dio Martino está atravesada por los principales elementos que se encuentran en el marxismo clásico, en especial en la relectura que hace Lenin y sus aportes sobre la cuestión política. En pocas palabras Martino nos decía: "Nosotros nos definimos como marxistas. Somos guevaristas, pero entendemos como guevarismo el marxismo leninismo. Esa sería la definición más acabada" (Martino, 2007). De este modo, el guevarismo es entendido como la aplicación, en estos tiempos y latitudes, de los principios del marxismo leninismo.

En el marco de estas coordenadas teórico-ideológicas adquiere absoluta relevancia el legendario debate entre revolución y reforma, presente entre las diferencias y fracturas de la propia organización. En líneas generales se hace hincapié en que la estrategia política hacia el socialismo implica la necesidad de una revolución social que destruya las instituciones políticas del Estado burgués. El reformismo es entendido como la disputa del Estado, la idea de que se puede avanzar en un proceso de transformación social revolucionario desde las propias estructuras del Estado Burgués. Así lo sintetiza Martino:

\begin{abstract}
El guevarismo para nosotros es el marxismo leninismo de hoy. Queremos decir que la guerra de clases es el motor. Queremos decir que no hay solución a los problemas del pueblo sin una revolución social. Y esa revolución social no significa disputar Estado. Significa abolir el Estado actual y construir un Estado nuevo. Esta es una de las grandes diferencias, de los grandes problemas que tenemos todavía en el campo popular. (...) el Estado es una maquinaria que diseña una clase para dominar a la otra. Por lo tanto esa maquinaria como tal no puede servir a la clase dominada para perseguir sus objetivos. Tiene que destruir esa maquinaria y construir otra. (Martino, 2007)
\end{abstract}

Siguiendo esta postura se destacan una serie de elementos que terminan de configurar el andamiaje ideológico-político de la organización. Así aparece la concepción de vanguardia, la que es definida como el surgimiento de un sector entre los propios militantes que logra desarrollar toda una serie de herramientas intelectuales para conducir con mejor criterio el rumbo de la organización, "es el obrero que se transforma en intelectual y el intelectual que se proletariza. Es decir, incorpora los conocimientos, pero adopta las formas, los puntos de vista de la clase obrera." (Martino, 2007). Del mismo modo aparece una concepción internacionalista de la revolución, en tanto se destaca que ninguna revolución se puede desarrollar "si no es a condición de que se desarrolle en otros países y entre ellos, en los mas avanzados" (Martino, 2007). Del mismo modo se menciona la importancia de partir de 
"la dialéctica del materialismo histórico" como perspectiva de análisis y visión de la sociedad.

Como bien lo señala el entrevistado, se trata de una aplicación de las principales definiciones del marxismo-leninismo como eje ordenador de la política de la organización. Justamente por la adopción de esta perspectiva, aparecen toda una serie de axiomas que definen a priori una cantidad de elementos por los que necesariamente -así aparece planteado- se deben orientar los esfuerzos políticos de la organización. El modo en que se resuelve la disyuntiva entre revolución y reforma no hace más que cerrar de antemano la posibilidad de pensar en un proceso político que no siga los parámetros que concibe la matriz marxista-leninista. Con otras palabras podemos decir que observamos una fuerte fijación de sentido en algunas definiciones -como revolución social, naturaleza del Estado, socialismo- que reducen el espacio de lo contingente y disminuyen la posibilidad de desarrollar operaciones de equivalencia a partir de significantes vacíos.

\subsection{Barrios de Pie (Libres del Sur)}

A diferencia de otras organizaciones del llamado campo nacional-popular, Libres del Sur se autorreferencia como una organización de izquierda, pero que ve en la "cuestión nacional" un punto de quiebre y distinción con la "izquierda tradicional":

"Me parece que nosotros somos una organización de izquierda. Pero bueno, una izquierda nueva, no una izquierda tradicional de ya un siglo de participación política en la Argentina, una izquierda que aparece producto de las últimas luchas, de los últimos 30/40 años del país. Tenemos una visión, justamente por eso surgimos, diferenciada del resto de las organizaciones de izquierda en cuanto a lo Nacional y Popular. Nosotros nos ubicamos dentro de lo que es la izquierda Nacional y Popular." (Baigorria, 2007)

Esta distinción aparece vinculada a otras valoraciones y distinciones relevantes que hacen a la autodefinición política de la organización. De este modo se le critica fuertemente a la "izquierda tradicional" su "falta de comprensión" respecto del peronismo $^{40}$ y su recurrente divorcio de la gente, en tanto plantean estrategias insurreccionales y revolucionarias que no tienen eco en las demandas concretas de las mayorías. De esta manera se produce una clara distinción entre la concepción de los procesos políticos, las demandas de la sociedad y las mayorías y la viabilidad de determinadas estrategias. Así señala, respecto a la crisis del 2001, que:

"La gente en definitiva puteaba masivamente, pero porque Argentina había caído en un desastre. Pero no por eso se estaba planteando la generación de nuevas opciones políticas. El trotskismo tenía una visión ahi de que estábamos ante una revolución inminente y lo planteó así

\footnotetext{
${ }^{40}$ Define al peronismo -el proceso político desarrollado por el propio Perón en sus presidencias y en su construcción- como "el momento más alto que tuvimos como pueblo, la participación en la distribución de la riqueza” (Baigorria, 2007)
} 
(...) Creemos que es altamente profundo el divorcio de la sociedad con sus representaciones políticas. Que exista ese divorcio no significa que la sociedad va a hacer emerger nuevas formaciones políticas. En aquel momento no había condiciones. Sí hay condiciones para unos procesos paulatinos, lo que vos vas viendo.(...) Para ese camino va la sociedad, no para un estado asambleario de soviets que van a generar otra salida política a la situación de crisis. Lo cual no implica ni que no haya crisis ni que sea altamente profunda, especialmente hacia los partidos tradicionales." (Baigorria, 2007)

Por su parte, las definiciones más precisas que encontramos en las publicaciones de la organización plantean como objetivos toda una serie de demandas que apuntan a mejoras graduales de diferentes dimensiones en dirección a "una Argentina con justicia social", sin establecer a priori rasgos necesarios que debiera tener el proceso que avance hacia aquella dirección. Esto es, no se establecen definiciones teórico-ideológicas que determinen el tipo de construcción política necesaria e ineludible, ni el modelo social con sus rasgos preestablecidos, sino una serie de reivindicaciones y puntos que actúan como eje ordenador. Así se plantean como fines de su construcción política:

"una nación reindustrializada, defensora de sus derechos e intereses en el ámbito internacional, integrada con sus hermanas latinoamericanas, con un Estado y un mercado interno fuertes; de empleo pleno y digno, sin pobreza, con justicia y movilidad social, donde se defienda el medio ambiente y haya educación y salud destacadas; con renovación institucional y política, sin corrupción; de igualdad de género y respeto a los derechos humanos, a los de las mujeres y los niños, los jóvenes y los ancianos, sin ninguna discriminación, con democracia real y participación popular. En definidas cuentas: un país en serio donde valga la pena vivir. (MBP, 2008)

Siguiendo con sus lineamientos generales se destacan en el Programa de Libres del Sur cuatro grandes dimensiones en las que enumeran toda una serie de puntos y principios ordenadores de la organización. En lo político se habla de 1) "democracia participativa", 2) "reformular el sistema político", 3) "construir un nuevo Movimiento Nacional" para una "refundación soberana del país", 4) reformular las fuerzas de seguridad y policiales, 5) "reconstruir el sistema judicial", 6) condenar los crímenes del terrorismo de Estado y de la represión y 7) elaborar una nueva Constitución Nacional sobre nuevas bases y valores. En lo económico se propone 1) un Estado fuerte e interventor, 2) la participación de los trabajadores en las empresas, 3) presupuestos participativos en los municipios, 4) renacionalización del gas y el petróleo, 5) reformulación del sistema impositivo, 6) la vuelta al sistema provisional de reparto, 7) fortalecimiento de la banca pública, 8) el apoyo a las PYMES, cooperativas y a la economía social, 9) reforma del régimen de tenencia de la tierra, 10) con "salarios justos, pleno empleo y trabajo digno", 11) "avanzando sin descanso hacia una justa distribución de la riqueza", 12) con defensa de la ecología y el medio ambiente y 
13) promoviendo el desarrollo científico-técnico nacional. En lo social se destaca la 1) universalización de la salud, educación y vivienda, 2) el resguardo de los derechos de las mujeres, 3) de los trabajadores, niños, jóvenes y ancianos, 4) de los pueblos originarios, 5) en contra de cualquier tipo de discriminación, 6) de la concentración de los medios de comunicación y 7) por la promoción de la cultura nacional. Por último, en "lo internacional" se menciona 1) la oposición al ALCA y a las presiones del FMI, OMC, etc., 2) la reivindicación de la soberanía sobre las Islas Malvinas y del Atlántico Sur, 3) la unidad latinoamericana, 4) el respaldo y defensa de los procesos políticos cubano, venezolano y boliviano ante las agresiones imperialistas, 5) la promoción y ampliación del MERCOSUR, entre las más relevantes. (LS, 2008)

En definitiva, encontramos una primera definición que ubica a la organización como parte de la izquierda, pero con una gran centralidad de la cuestión nacional. Esto deriva en definiciones políticas que incluyen un modelo país con justicia social, en el que se destaca toda una serie de puntos y reivindicaciones que son considerados como principios rectores del desarrollo político de la organización. Hay una concepción del cambio que es gradual, que implica la constante observación del humor social y el apoyo de las mayorías, y que por tanto, busca seducir y construir ese consenso que es entendido como imprescindible para avanzar en las direcciones planteadas. En tal sentido, la variante insurrecional como estrategia política no es considerada como una de las alternativas más viables, y mucho menos, como la única alternativa posible. Del mismo modo no hay un modelo de sociedad preestablecido que aparezca como objetivo último y que sea definido en sus componentes generales, sino que se plantean grandes metas aunque no están claras las opciones que podrán entrar en juego para alcanzarlas. Dicho de otra manera, se busca una sociedad con justicia social, una sociedad equitativa, pero no se establece de modo necesario o determinante que aquello se alcance mediante una dictadura del proletariado, con la socialización de los medios de producción o mediante otro mecanismo preestablecido. En cualquier caso el tema aparece planteado más en términos políticos -de lecturas sobre las relaciones de fuerzas- que como medidas técnicas o económicas. La posibilidad de romper con determinados niveles de dependencia política, económica y cultural con los países centrales aparece como un tema central.

\subsection{Medios y fines de la práctica política. Una primera taxonomía.}

En relación a nuestro tema de análisis podemos distinguir en primer lugar dos grandes grupos entre las organizaciones estudiadas respecto a la autodefinición ideológica que cada una señala y que tiene que ver con la adscripción o no al marxismo-leninismo. En efecto cuatro de las ocho organizaciones observadas se 
presentan adhiriendo a la matriz ideológica marxista-leninista, sintetizando una serie de rasgos comunes que dan cuenta de una particular fijación de sentido respecto a los significantes y puntos nodales en torno de los cuales se construyen sus discursos identitarios. En este sentido, nos parece relevante resaltar la aparición del leninismo configurando, junto con la apelación al marxismo, la constitución de una matriz ideológica que aparece indisoluble para un grupo de organizaciones que adscriben explícitamente a ella desde diferentes orientaciones.

Tanto el PO, la CCC-PCR, el MTR y el MPR-Quebracho ${ }^{41}$ se definen como marxistas-leninistas y comparten una serie de rasgos comunes que a la vez las diferencia del resto. Entre los puntos más importantes que podemos destacar en este apartado está la concepción de la revolución como proceso de transformación radical que se opone a reformas graduales y una mirada binaria del escenario político que resulta de la traslación del modelo dicotómico marxista. Salvo el caso del MPR-QB, el resto de las organizaciones plantean un punto de llegada claro y preestablecido: el socialismo es entendido según los lineamientos teóricos de la matriz marxista-leninista y sujeta a las experiencias históricas en las que la revolución rusa tiene un lugar predominante. El proceso de transformación social aparece preestablecido en muchos de sus componentes más importantes, desde la forma que adoptará el proceso de cambio -la revolución-, hasta el fin, el punto de llegada -el socialismo/comunismo, socialización de los medios de producción mediante.

En este sentido podemos señalar que se observan una serie de puntos nodales (revolución -vs. reforma-, socialismo, dictadura del proletariado) que se plantean en términos de una plena fijación de sentido. Hay un objetivo final, un tipo de sociedad al que se quiere llegar, que ya está definido en sus componentes principales. Esto a la vez implica una serie de pasos que se presentan como necesidades, cuestiones ineludibles que restringen fuertemente el espacio de lo contingente.

El caso del MPR-QB es una suerte de híbrido, en donde se trata de conjugar la matriz marxista-leninista (especialmente tópicos como revolución y insurreccionalismo) con elementos de la matriz nacional-popular. La primacía de la práctica (política) como rasgo identitario termina subordinando otros componentes del discurso a la lógica insurreccionalista y al enfrentamiento, buscando articular la idea de revolución con elementos nacionalistas. Es decir, en este modelo no se presenta como necesaria la socialización de los medios de producción ni la abolición del Estado burgués, pero sí el cambio social es presentado circunscrito dentro de los límites del insurreccionalismo.

${ }^{41}$ Cabe señalar que el MPR-Quebracho si bien se presenta en primera instancia como Nacionalista Revolucionario con fuerte vinculación a la matriz nacional-popular, luego señalan explícitamente su adhesión al marxismo leninismo "en cuanto a cosmovisión del mundo, categorías de análisis y filosofía política”. Esta doble adscripción ideológica trae diversas implicancias que serán señaladas más adelante. 
Entre las organizaciones que no se presentan como marxistas-leninistas se observa como rasgo común una concepción del escenario político que trasciende la lógica binaria marxista, lo que no implica que deje de reconocerse la contradicción entre capital y trabajo como eje para pensar lo social, pero sí que se reelabore dando lugar a nuevos antagonismos ya no circunscriptos al estricto corte de clase: pueblo vs. Oligarquía, liberación vs. dependencia. Tanto en el caso de las organizaciones cercanas a la matriz nacional popular (el MUP y MBP-LS), como en las que incluiríamos en una suerte de izquierda heterodoxa (FPDS y MTD-AV), el cambio social se orienta hacia un modelo social equitativo, donde se zanje la brecha entre ricos y pobres. Al interior de estas coordenadas se admiten una serie de posibilidades que no son contempladas/aceptadas por el otro grupo de organizaciones como alternativas viables. Es por esto que decimos que el punto de llegada se presenta con una fijación de sentido visiblemente menor.

Del mismo modo la concepción de cambio social está definida más en términos de posibilidades -o probabilidades- que en términos de necesidades. No constituye un debate central la destrucción o no del Estado en tanto es vista como una discusión abstracta, lejana, en relación a las dificultades que manifiesta el campo popular para revertir la desfavorable correlación de fuerzas respecto a sus enemigos políticos. Como se ve en los discursos, el espacio de lo contingente avanza en detrimento de lo necesario, ampliando -eso creemos- las posibilidades para que se desarrollen lógicas equivalenciales a partir de la operación de significantes vacíos. Esto, a su vez, puede entenderse como uno de los elementos que instala condiciones para desarrollar articulaciones políticas de alta intensidad.

En definitiva, pensamos que puede resultar útil esta separación en función del peso que adquieren determinados elementos de la matriz marxista-leninista, en tanto permiten, más allá de las diferencias, observar algunos rasgos comunes que nos aportan información sobre el tipo de fijación de sentido que se le imprime, desde el discurso identitario, a la concepción de lo social -el tipo de sutura-, la visón de lo político y sus implicancias en el derrotero político de cada organización. Veremos más adelante si esta categorización continúa siéndonos útil. 


\section{CARACTERIZACIÓN DE LAS OTRAS FUERZAS DEL CAMPO POPULAR}

Pensar en procesos de articulación política implica tener determinadas visiones valorativas de los potenciales aliados, que compartan una serie de valores, objetivos y estrategias, con los cuales se puede coincidir lo suficiente cómo para que dichos procesos de articulación sean viables. Pasaremos a observar como son vistas y presentadas las distintas formaciones políticas del campo popular por las propias organizaciones analizadas. Creemos relevante analizar esta cuestión en tanto nos aporta elementos para ver los espacios -las posibilidades- que se abren para procesos de articulación en los discursos de las organizaciones estudiadas.

De esta manera intentaremos dar cuenta de cómo operan las lógicas de equivalencia y diferencia, en tanto se delimita el espacio de la identidad a partir de lo que las organizaciones no son, es decir, dando cuenta del exterior constitutivo, aquello que diferencia la propia formación política del resto. De este modo, se van precisando los límites que delimitan las identidades propias y, por tanto, las ajenas.

\subsection{Polo Obrero (Partido Obrero)}

Cómo señalábamos más arriba, el PO posee un discurso fuertemente distintivo respecto del resto de las formaciones políticas del campo popular. Es decir, se hace especial hincapié en constatar las diferencias que aparecen en el plano políticoideológico y la importancia que esas diferencias tienen a la hora de pensar en posibles procesos de articulación. Las diferencias que se presentan en el plano ideológico se reproducen -y hasta se magnifican- en el ámbito de las prácticas políticas.

Así podemos resaltar algunas menciones que se hacen a lo largo del discurso en referencia a otras formaciones políticas del campo popular. En primer lugar se menciona a la CCC y a la FTV como las principales responsables del fracaso del proceso de articulación que se empezaba a construir en el marco de las Asambleas Piqueteras de julio y septiembre de $2001^{42}$. También son acusadas de levantar una movilización programada para el 20 de diciembre de 2001, como de ser cooptadas, junto con el MTA de Hugo Moyano por el gobierno de Duhalde.

Y teníamos para el 20 de diciembre una movilización precisamente convocada, que levantan la CCC y la FTV. (...)

el consejo consultivo de Duhalde, con la Iglesia de por medio, había logrado incorporar a la CTA, la CCC y por supuesto también al MTA de Hugo Moyano. De manera que los que protagonizaron importantes movilizaciones del llamado campo popular en la etapa final de Menem, habían sido cooptados al gobierno duhaldista. (Pitrola, 2007)

\footnotetext{
42 "El Argentinazo rompió la Asamblea Piquetera porque dos de las fracciones no jugaron en la rebelión del 19 y 20 de diciembre. FTV y CCC " (Pitrola, 2007)
} 
El tema de la cooptación es bastante recurrente. Más allá de su significado original o académico ${ }^{43}$, el verbo cooptar suele ser empleado vinculado a la idea de hegemonizar, de absorber al interior de una fuerza política poderosa, fuerzas más débiles, las que por su propia debilidad son cooptadas. Desde esta perspectiva la cooptación incluye la traición o claudicación de las propias convicciones en pos de la acumulación de poder al interior de una fuerza hegemónica y más poderosa, en este caso el gobierno. De esta manera, todas aquellas organizaciones que tomaron la decisión de acompañar el proceso político que encabezaba Néstor Kirchner desde la presidencia, son rápidamente condenadas y estigmatizadas. La crítica y condena a la cooptación por parte del gobierno de Kirchner es un elemento muy recurrente en las valoraciones por parte de diversas organizaciones. Destacando los rasgos distintivos del kirchnerismo, Pitrola señalaba

\begin{abstract}
La diferencia es el fenómeno de la cooptación política de organizaciones del campo popular. Entonces vos fijate la cooptación de Madres, la cooptación de organizaciones de derechos humanos de diversas características. Abuelas, Madres y otros. La cooptación de izquierda del movimiento piquetero: la FTV, Barrios de Pie, otros sectores, el MTD Evita.... Cuestión que no se ha detenido hasta el presente porque la ruptura de Izquierda Unida no es ajena a la cooptación kirchnerista. Fijate vos que el PC se asimila con Filmus en la Capital. Se integra al juecismo en Córdoba, que sería una variante más o menos articulada con el gobierno. Entonces, la cooptación es muy importante, es un método absolutamente clásico de los gobiernos nacionalistas, como también es clásica la persecución, la represión y las patotas sobre los que no se adaptan a esa cooptación política. (Pitrola, 2007)
\end{abstract}

Resulta llamativo que las organizaciones aparecen desde esta perspectiva como fuertemente pasivas, incluso carentes de la capacidad de análisis que les permita evitar ser cooptados. Dicho de otro modo, no se concibe la posibilidad de que las formaciones políticas que pasan a ser aliadas del gobierno, lo hagan a partir de las propias convicciones, de un determinado diagnóstico a partir de sus propias categorías ideológicas. La utilización del término de cooptación, remite entonces a una perspectiva que ve a las organizaciones como engañadas, manipuladas, sin poder de decisión. Esto, a su vez, lleva a una fuerte descalificación de una gran cantidad de formaciones del campo popular.

En la misma línea, pero yendo todavía más allá, también se le achaca a estas organizaciones cierta bajeza ética en tanto se desliza la acusación de que lo central es la búsqueda de cargos públicos per se: "con esta tesis de cambiar por dentro al gobierno, que es más una excusa para ocupar cargos públicos que para otra cosa." (Pitrola, 2007)

\footnotetext{
${ }^{43}$ El verbo cooptar aparece definido en el diccionario de la Real Academia Española como "Llenar las vacantes que se producen en el seno de una corporación mediante el voto de los integrantes de ella.". (ver: http://www.wordreference.com/es/en/frames.asp?es=cooptar ).
} 
Es decir, no sólo se trata de organizaciones que no tienen capacidad de decisión, que no pueden optar a partir de su diagnóstico y convicciones por determinado camino político, sino que además terminan siendo meros buscadores de cargos públicos, desprovistos de cualquier intencionalidad política legítima.

También se pueden observar menciones respecto a otras organizaciones que aparecen criticadas por otras razones, pero en general se mantiene un criterio según el cual una gran cantidad de organizaciones terminan desviando el camino, "girando hacia el centro" o perdiéndose en una nebulosa y en confusiones respecto al verdadero camino a seguir. De este modo, aparecen distintas formaciones políticas fuertemente criticadas por diversas conductas equivocadas. Del MTR de Martino menciona lo siguiente:

Mirá Martino hace rato que está planteando... El rompió el Bloque
Piquetero y todo lo demás con un giro hacia la centro izquierda. Y hace
rato que está planteando el entendimiento. Ahora apoya la
Constituyente Social de la CTA, que es un indisimulable perro para
meterse adentro del pacto social por parte de la CTA. Y con eso van al
diálogo social. La CTA que ya estuvo con Duhalde, que estuvo en todos
los pactos, que está con Yaski. Imaginate ir a comprar eso. (Pitrola,
2007 )

En la misma línea aparece vinculado el MTD Aníbal Verón, pero aquí ya se lo vincula con el autonomismo: "Lo mismo pasa con el MTD Aníbal Verón, que ha sufrido muchísimas crisis. Forma parte de una corriente autonomista que ha agotado su tiempito histórico." (Pitrola, 2007). Por último, se detiene en duras críticas respecto al papel de la CCC en diferentes instancias:

"Y bueno la CCC forma parte de otro debate. Compartimos muchas luchas comunes. (...) En general todavía se mantienen más aliados a la burocracia peronista y a la CTA que al campo clasista. Por ejemplo están con Baradel en el CTA de la provincia de Buenos Aires."

"Y en el plano político, su abstencionismo encubre la idea de que el día que se presenten a elecciones están con alguna variante de la burguesía. La última vez que votaron, votaron a Menem. Después no volvieron a votar."

"Entonces son corrientes que también, el caso de la CCC, tienen planteos distintos en cuanto al papel de las clases sociales en un proceso de liberación nacional. Muy diferente. Y muy parecido históricamente al del PC. Surgen de ese tronco político." (Pitrola, 2007)

Finalmente se centra en la valoración respecto al gobierno de Kirchner y las posturas, tanto de la CCC como del MTD Aníbal Verón. Ambas organizaciones son criticadas por no adoptar una posición lo suficientemente opositora al gobierno.

Ellos apoyaron los primeros años del gobierno de Kirchner. Llevó a Kirchner a La Matanza. La llevaron a Alicia Kirchner a sus emprendimientos. Tuvieron acuerdos alrededor del cooperativismo, de los microemprendimientos. Y bueno, en muchas etapas del movimiento piquetero ellos, junto con el MTD Aníbal Verón, fueron una variante intermedia entre el kirchnerismo y los que resistimos contra el gobierno desde el primero hasta el último día. Han ido y venido. (Pitrola, 2007) 
Retomando algunos de los conceptos con los que venimos trabajando, podemos señalar que las referencias a otras organizaciones del campo popular aparecen, en el discurso de este dirigente del $\mathrm{PO}$, marcadas por una fuerte lógica de la diferencia, según la cual los recorridos y opciones políticas que no se ajustan a lo esperado desde las propias categorías son rechazados enfáticamente. De este modo esta lógica de la diferencia plantea, al interior del campo popular, un ellos que es caracterizado a partir de diversos rasgos, pero que todos giran en torno a claudicaciones, desvíos, incapacidad y oportunismo; viciados por la pérdida de determinada independencia de clase. En contrapartida, el nosotros se caracteriza por la coherencia respecto a la lucha clasista, a la independencia de clase y a la consecuencia con los valores realmente revolucionarios.

Pese a la contundencia con la que se establecen las diferencias al interior del campo popular, Pitrola concluye la entrevista con un tono amistoso respecto a sus pares (las otras formaciones políticas), dando cuenta en definitiva de la existencia de un espacio político -el campo popular o como se le llame- de convivencia y posible articulación.

\section{P: Decime 2 o 3 organizaciones o partidos del campo popular con los que te sientas más cercano políticamente \\ $R$ : No te lo contesto porque es negativo. No hay aproximaciones. Todas las organizaciones que están en el campo de la lucha son muy respetadas por nosotros. Sus activistas, sus compañeros $y$ permanentemente tenemos acuerdos de lucha. No voy a privilegiar unos contra otros, no está en nosotros. (Pitrola, 2007)}

Resulta llamativo cotejar por un lado este discurso conciliador y de apertura respecto a la posibilidades de articulación política con el resto de las formaciones del campo popular, mientras que al momento de referencias específicas, las principales organizaciones aparecen fuertemente cuestionadas, reduciendo visiblemente el espacio para las articulaciones políticas. Nos referimos puntualmente a la rigidez con la que aparecen planteadas determinadas líneas a seguir y la severidad con la que es evaluado el respeto o no de dichos lineamientos.

\subsection{Corriente Clasista y Combativa (PCR)}

Un dato reconocido por muchos, incluso por los propios entrevistados de las diferentes organizaciones, es que la $\mathrm{CCC}$ es una organización que ha logrado establecer gran cantidad de acuerdos y alianzas políticas con diversos actores. Hemos podido observar en su accionar y su discurso una marcada vocación por consolidar frentes políticos con actores variados. Así lo manifiestan en su programa cuando señalan que "La lucha por la hegemonía del proletariado es imposible sin una política 
permanente de frente único que apunte a conformar el bloque histórico de clases revolucionarias." (PCR, 2004) En el mismo sentido se manifiesta Ardura cuando afirma que: "Nos peleamos y nos entendemos con todos. Algunos más que otros." (Ardura, 2007)

Ahora bien, paralelamente a estas manifestaciones y al propio accionar de la organización, notamos que existe una visión fuertemente crítica y, por momentos, claramente peyorativa respecto a organizaciones con las que, por otra parte, se pretende conformar alianzas políticas de carácter estratégico. Un ejemplo de esto es la crítica apreciación respecto a aquellas organizaciones del campo popular que optan por participar en las contiendas electorales. Sobre ellos señala Ardura:

Todo el fraccionamiento está complicado, pero nosotros en ese sentido tenemos una ventaja: al no ser unos cretinos parlamentaristas no nos dividimos por las elecciones. (...) No hay más que leer los diarios de nuestros amigos y compañeros... es un drama. Son todos enemigos, democratizantes reformistas. (...) A mi no me da alegría que hagan esa pantomima. Me da tristeza, dolor. Siento ese dolor. ¿Cómo pueden ser tan pelotudos? Bueno, que va a ser. (Ardura, 2007)

Por otra parte señala la presencia de agentes del imperialismo, en especial del imperialismo ruso, que han "contaminado" muchas organizaciones ${ }^{44}$. Aquí se remite tangencialmente al Partido Comunista en términos generales y explícitamente se menciona al ERP y a Montoneros, como víctimas de eso. De esta manera se descalifica de antemano a distintas organizaciones las que son señaladas directamente como funcionales al enemigo.

También crítica a la CTA por no coincidir en la visión clasista y confundir las contradicciones principales y los enemigos y no ser consecuentes con la estrategia política que, según ellos, es la adecuada. En particular se refiere a la necesariedad de la etapa de la dictadura del proletariado, como un paso indispensable que no aparece en la estrategia de la CTA. ${ }^{45} \mathrm{El}$ acercamiento de sectores de la CTA con el gobierno de Kirchner, sin dudas resulta como un claro parte aguas y el otrora aliado en el llamado "eje matancero" aparece para Ardura como una de las organizaciones del campo popular de las que más alejado se siente.

\footnotetext{
${ }^{44}$ Nos referimos a los siguientes fragmentos de la entrevista con Ardura: "Pero quiero decir que las clases dominantes en la Argentina tienen muchos agentes en el movimiento obrero. Productores de ideas. Te estoy hablando de los agentes que tienen todos los imperialismos. Pero particularmente los que han hecho mucho daño, han sido los rusos."(...)"Porque esta es la misma teoría de ERP y Montoneros, por otra vía. Es decir no zafás teóricamente del paraguas que te ha metido el imperialismo" (Ardura, 2007)

45 "Todos hablan de socialismo. Mov. Socialista de los Trabajadores... Vos lo agarrás a De Gennaro y le preguntas ¿vos por que estás? Yo por el socialismo. Pero como para llegar a ese socialismo, que no dicen dictadura del proletariado, porque cualquier buen hijo de vecino revolucionario, cuando habla de socialismo habla de dictadura del proletariado.", en Ardura, 2007
} 
También se critica al FPDS, al que se le critica su "doble discurso" en tanto se dicen autonomistas y sin embargo no tienen reparo en que participen sus cuadros en el armado del gobierno de Kirchner:

Ahora todos están terminando con la cola atada con un sector del poder. Como los compañeros de la Darío Santillán, que tienen muchas de estas historias de por medio. Estos autonomistas tienen al Secretario del plan agropecuario de la Secretaría de Agricultura, Ganadería y Pesca. Es decir, tanta autonomía, pero con una mano agarrada del Estado, del poder. (Ardura, 2007)

Luego aparecen consideraciones benévolas hacia diferentes actores, resultando llamativo que a quienes se menciona como "más cercanos políticamente" no formen parte de lo que habitualmente se conoce entre las organizaciones como pertenecientes al campo popular. En efecto, salvo el MTD Aníbal Verón, que aparece mencionado como organización cercana ${ }^{46}$, aparecen mencionadas figuras parlamentarias cercanas al Partido Afirmación para una República Igualitaria (ARI) especialmente, aunque no sólo, dentro de lo que se conoce como el ARI disidente-, como son Margarita Stolbizer, Eduardo Macaluse y Marta Maffei.

Recapitulando podemos decir que la CCC se presenta como una organización que mantiene una postura de amplitud y flexibilidad a la hora de actuar y relacionarse políticamente con otras organizaciones. Esto puede verse en las variadas alianzas y acercamientos que viene teniendo con otras organizaciones. Paralelamente notamos cierta dureza en las críticas hacia sus pares lo que induce a pensar en límites respecto a la profundidad y perdurabilidad de dichas alianzas. Esto es, en la medida en que las diferencias son tratadas como equivocaciones o errores de los otros, el espacio de la articulación se reduce a que el resto reconozca la "verdadera senda revolucionaria". Desde esta perspectiva, no estamos lejos de la postura que observamos en el PO.

Por todo esto observamos cierto instrumentalismo respecto a los otros actores, en la medida en que la propensión a la articulación (casi indiscriminada al interior del campo popular) sugerida en el "nos peleamos y nos entendemos con todos", no aparece acompañada por una flexibilización en los principios sobre los que se estructura la identidad política de la organización. ${ }^{47}$

Siguiendo los conceptos con los que venimos trabajando, podemos señalar que la lógica de la equivalencia sobre la que la CCC construye sus múltiples y variados acuerdos y alianzas políticas pareciera que se desarrolla sobre una identidad política fuertemente cerrada que no es puesta en cuestión ni revisada a la luz de los elementos que sugieren las organizaciones pares. Se proclama la necesidad de

\footnotetext{
${ }^{46}$ Aunque no se pierde la oportunidad de imputarle un abandono en una movilización conjunta reciente.

${ }^{47}$ Algo de esto quizás este presente en lo que decía Ardura: "Que se yo... Nosotros tenemos momentos y momentos. Si te digo históricamente tenemos relación con todos. Y sabemos utilizar o buscar los momentos." (Ardura, 2007)
} 
desarrollar un Frente Único, pero se hace hincapié en la suma de sectores sociales (el estudiantado, los intelectuales, cierto sector de la burguesía nacional, etc) y no en la necesidad de articular con otros partidos y formaciones políticas. Es ilustrativo al respecto que en el Programa se hable siempre de "EL Partido" o del "proletariado y SU Partido", por supuesto, haciendo mención al propio partido. Un ejemplo muy claro de esto que venimos señalando es el párrafo inicial del Programa citado anteriormente que señala:

\begin{abstract}
El Partido Comunista Revolucionario de la Argentina es el partido político revolucionario del proletariado, la forma superior de su organización de clase. Es su destacamento de vanguardia, el destacamento nacional de una clase que es internacional, integrado por los mejores hijos de la clase obrera y el pueblo.(...) La teoría que guía la acción es la teoría revolucionaria del proletariado: el marxismoleninismo-maoísmo" (PCR, 2004) El subrayado es nuestro.
\end{abstract}

No es preciso hacer un agudo análisis semántico para distinguir algunos de los principales supuestos presentes en estas definiciones: EI PCR es el único partido político revolucionario del proletariado en la Argentina, la forma superior de su organización clase, su vanguardia. Del mismo modo, la única teoría revolucionaria del proletariado es el marxismo-leninismo-maoísmo.

También observamos que no se establece una distinción entre el plano económico en el que se constituyen los sujetos sociales y el plano de lo político, el de la acción, el de posicionamiento, el de los procesos de significación y constitución ideológico-política. De esto se desprende que el frente único que proponen sea la suma de grupos definidos socio-económicamente, obviando la multiplicidad de actores y posiciones políticas que conviven y resultan de cada uno de estos sectores socioeconómicos. El proletariado tendrá su partido, que presumiblemente será el PCR, que a la vez hegemonizará aquel frente único que llevará a cabo la revolución. Siguiendo esta lógica -y las opciones que se desprenden de ella- se supone que la multiplicidad de partidos y formaciones políticas del llamado campo popular terminarán encolumnándose detrás del $\mathrm{PCR}$, se extinguirán, mirarán con indiferencia lo que sucede o pasarán a formar parte del campo enemigo.

\title{
3.3. Movimiento de Unidad Popular
}

El campo popular es entendido desde el MUP desde un doble registro: por un lado -y en primer lugar- se tiene en cuenta la condición laboral, la pertenencia al sector asalariado, a la clase trabajadora. Así aparecen en primer lugar las dos grandes centrales trabajadoras de la argentina, la CGT y la CTA, como las exponentes de la clase trabajadora organizada, independientemente de la dirección política que sus dirigencias le impriman a sus gremios. Simultáneamente se incluyen a las diferentes 
organizaciones sociales, que más allá de su extracción de clase (aunque la mayoría de ellas provienen de los estratos sociales más bajos) orientan su trabajo político a favor de los sectores populares y en contra de los grandes poderes sociales y políticos.

Para mi el campo popular, son: las 2 centrales sindicales, los movimientos sindicales, los movimientos culturales, un arco amplio que va de la asamblea de Gualeguaychú hasta la lucha de las Madres Contra el Paco, en todo este arco político, social, ideológico y cultural, está en expansión, se está consolidando. (Martelli, 2007)

A partir de estas definiciones sobre lo que se considera el campo popular, aparecen menciones sobre otras organizaciones, las que están fuertemente atravesadas por la coyuntura política actual, en donde el posicionamiento respecto al gobierno de Kirchner resulta central. En primer lugar hay una fuerte crítica a las dirigencias sindicales de Luis Barrionuevo y Rodolfo Daer, identificados como actores que se oponen las transformaciones positivas que intenta llevar a cabo el gobierno de Kirchner.

En relación a las organizaciones de izquierda - de orientación ideológica marxista- se critica el hecho de que plantean sus tesis "en blanco o negro", que no alcanzan a distinguir la complejidad política y la gradualidad de los procesos.

Veo que hay casos de gente muy piola que mide las cosas en términos ideológicos. Por ejemplo: yo estoy en contra de la explotación del hombre por el hombre. Como este es un modelo capitalista, estoy en contra de Kirchner. Como podemos estar en contra de Chávez, que sigue siendo un modelo de capitalismo nacional. (Martelli, 2007)

En la misma línea destaca el carácter artificial de ciertos posicionamientos políticos e ideológicos también vinculados al marxismo, que no tienen arraigo en los sectores populares y que por tanto carecen de efectividad política. En relación a las organizaciones trotskistas su valoración es determinante y son considerados como una minoría insignificante ajena a las verdaderas disputas políticas que se llevan a cabo, incluyendo críticas hacia la integridad ética de algunos dirigentes. ${ }^{48}$ También se deslizan críticas hacia la $\mathrm{CCC}$, la que es considerada una organización respetable, pero que en la coyuntura actual al ser acérrima opositora al gobierno nacional, aparece como distante.

\footnotetext{
48 "No me siento ni distante ni cercano. No los considero. No aportan ni restan. Hay grupos y grupos. Hay grupos trotskistas más grandes, más chicos. Si me siento distante evidentemente. Que se yo, del Polo Obrero me siento distante. Más que distancia siento lástima por tanta buena voluntad puesta en muchos pibes al pedo." (Martelli, 2007).

"Después hay gente que tienen mala voluntad o que realmente vive en términos económicos, con un determinado esquema... Dirigentes históricos del PO, del que fuere. Yo se que viven del Partido... Es una lástima que conduzcan a tantos laburantes, tantos compañeros jóvenes, sin dar esta discusión más sincera dentro de su cuerpo." (Martelli, 2007)
} 
Entre las formaciones políticas que son positivamente valoradas aparece la CTA, el Movimiento Agrario Misionero (MAM) y el Movimiento de Madres contra el Paco como menciones en la entrevista, mientras que en la página web hay una mención explícita de la agrupación La Cámpora y de la necesidad de "desarrollar una fuerza política a nivel nacional que sea parte integral del Frente para la Victoria" (MUP, 2008).

La categorización de las otras fuerzas del campo popular está cruzada por la matriz nacional-popular que a la vez se ve fuertemente condicionada por la coyuntura política actual. Debemos notar en este sentido, que la CTA es claramente valorada por el MUP, pese a no constituir una organización oficialista ni apoyar el proyecto político del gobierno tal cual lo hace el MUP. Esto obedece a coincidencias ideológicas, al hecho de compartir los lineamientos nacional-populares y pese a las diferencias de coyuntura. De todos modos, y justamente por tal apreciación -la coincidencia en los aspectos centrales-, Martelli augura un próximo espacio de articulación entre las fuerzas del campo nacional.

\subsection{Frente Popular Darío Santillán}

La valoración positiva o negativa sobre el resto de las organizaciones del campo popular está atravesada en el FPDS más por el posicionamiento político concreto que por lineamientos ideológicos profundos. De hecho ellos gustan señalar que la matriz ideológica no es un elemento determinante a la hora de pensar las cuestiones, hecho que tiene que ver con su propia historia, producto de la articulación de grupos con ascendentes ideológicos disímiles. Desde ya que no desconocemos seguramente ellos tampoco- que las diferencias que se plantean en la práctica concreta también remiten a diferentes marcos ideológicos con los que es aprehendida la realidad.

Cuando consultamos a Obregón sobre aquellas organizaciones de las que se sentía más cercano aparece en primer lugar el Frente de Organizaciones en Lucha (FOL) y luego se mencionan otras más conocidas pero en un segundo plano, como parte del gran conjunto de las organizaciones con las que no tienen dificultades para relacionarse. En general destaca esta situación que mencionábamos más arriba según la cual la matriz ideológica no es un condicionante para la relación. Del mismo modo se observa una concepción sobre la articulación que se presenta en términos de coordinación, como un nivel de relación circunstancial y concreto que incluye -o puede incluir- claras diferencias estratégicas. Así nos respondía Obregón:

\section{P: Decime 2 o 3 organizaciones/partidos con las que te sientas más cercano políticamente y por qué.}


R: Tenemos buena relación con el FOL, Frente de Organizaciones en Lucha, una coordinadora de organizaciones piqueteras y otros grupos más con los cuales hemos coordinado varias cosas. Tenemos coordinaciones con muchas organizaciones que tal vez tengamos diferencias, pero con las cuales coordinamos en cuestiones puntuales. Con la CCC, con el PO, con el MST. Tenemos coordinaciones. Diferencias en cuanto a lo estratégico, pero a veces en algunas cuestiones prácticas hay posibilidades de acordar. El diálogo es permanente y muchas veces nos encontramos en la calle. HIJOS La Plata, una organización que nos parece que es un punto de referencia muy importante, por lo menos acá en la región. Que sirve a veces para acercar posición entre diferentes grupos porque justamente tienen un prestigio y una trayectoria que los coloca en un lugar de moderadores. (Obregón, 2006)

Además de lo que señalábamos más arriba resulta interesante la aparición de HIJOS La Plata, no sólo como una organización cercana, sino además con un rol moderador entre las distintas posiciones. Probablemente tal rol esté vinculado a sus rasgos no estrictamente políticos que quizás la ubiquen en un lugar diferente que al resto de las organizaciones con intereses que se circunscriben a lo político.

Del mismo modo, cabe señalar que más allá de no cerrarle la puerta a nadie, no se desconocen las diferencias. Veíamos en el apartado anterior una dura crítica a los partidos que se consideran embriones del partido revolucionario, con la explícita mención del PO, pero refiriéndose además a otras organizaciones de manera implícita.

Sin embargo, atados a las valoraciones de la realidad política concreta y utilizando tal parámetro como central, las diferencias más importantes aparecen con las organizaciones que se han integrado o acercado al kirchnerismo. Pese a plantear una suerte de posición intermedia en relación al gobierno -no exenta de críticas, pero diferente de la "línea dura" de otras organizaciones- son las organizaciones cercanas al gobierno las señaladas como más lejanas.

\begin{abstract}
P: Decime 2 o 3 organizaciones/partidos del campo popular con las que te sientas menos identificado/cercano políticamente y por qué. $R$ : En este momento con las organizaciones que están más cerca del gobierno. Barrios de Pie, MTD Evita. Creo que son organizaciones del campo popular, pero las diferencias son importantes, muchas veces no nos permiten estar en la calle en un mismo reclamo. En general te juntas con estos compañeros cuando el eje es un eje anti-represivo o vinculado a los derechos humanos. Pero ahí la caracterización del gobierno funciona como una bisagra. (Obregón, 2006)
\end{abstract}

Como puede verse, el FPDS desestima cuestiones más vinculadas a matrices ideológicas a la hora de pensar y valorar a las organizaciones pares, mientras que prioriza los posicionamientos concretos de la coyuntura política y los métodos de construcción. Esto, en verdad tiene que ver con el tipo de elementos que definen su cuerpo identitario, que busca alejarse de las posiciones más dogmáticas mediante un modelo que deje abiertas alternativas en cuanto a los fines que orientan sus accionar. 
Los medios, las formas de construcción política, adquieren una importancia ausente en otros discursos, argumentando la imperiosa necesidad de mantener una suma coherencia entre estos y los fines últimos.

\subsection{MPR-Quebracho}

Cuando le preguntábamos a nuestro entrevistado sobre aquellas organizaciones del campo popular de las que se sentía más cercano y sobre las que se sentía más alejado, aparecen entremezclados tanto los grandes trazos políticoideológicos -la matriz "nacional-popular"- como el posicionamiento político práctico y concreto. De este modo aparecen como organizaciones o sectores políticos más cercanos referentes como Mario Cafiero y el diputado Claudio Lozano o el Proyecto Sur de Pino Solanas, es decir vinculados a la matriz nacional-popular opositores al kirchnerismo.

En segundo lugar aparece mencionado el PCR, lo que pareciera estar vinculado con la centralidad que adquiere el tipo de práctica política -ambas organizaciones son públicas defensoras del insurreccionalismo- a la hora de pensar acercamientos y distancias. Sin embargo, lo que se destaca en el discurso es la mirada común sobre la cuestión del poder y sobre la cuestión nacional:

Con el PCR, si querés, hay una concepción de práctica política similar, en un sentido. En como concebimos la cuestión del poder y como concebimos la cuestión nacional. Y después tenemos diferencias en la traducción de esas cosas. Sería lo más parecido a nosotros, si querés en ese sentido. (Esteche, 2007)

Es decir más allá de algunas diferencias que podemos observar en la autodefinición ideológica de cada una de estas organizaciones, relacionadas con el peso del clasismo, con el etapismo, con la necesidad de privilegiar determinados sujetos sociales, etc., terminan primando las semejanzas y equivalencias que se dan en el plano de la práctica política, donde entendemos que el peso de lo insurreccional adquiere gran centralidad.

En la misma línea, las organizaciones del campo popular que aparecen más alejadas políticamente son aquellas que hoy están alineadas con el gobierno -se menciona al "Barba" Gutiérrez, a D'Elía y a Barrios de Pie- dando cuenta de la centralidad de la práctica política -del posicionamiento político concreto de cada organización en la coyuntura política- en detrimento de cuestiones más conceptuales o ideológicas -una matriz nacional-popular común.

Luego aparecen menciones sobre otras organizaciones y referentes del campo popular, atravesadas por diversas críticas que amplían la caracterización de dicho espacio político. De este modo, aparece una fuerte crítica a lo que llaman el 
"travestismo político" de muchas organizaciones que, desahuciadas, se "refugiaron" en las organizaciones territoriales y de desocupados en donde desarrollaron prácticas reivindicativas evitando las discusiones eminentemente políticas, las discusiones sobre el poder. Para Esteche esto obedece a la inseguridad política de muchas organizaciones -principalmente se trata de organizaciones "de izquierda"- que "no se hacen cargo" de los debates realmente políticos.

Otra crítica recurrente en el discurso tiene que ver con la disyuntiva entre la gobernabilidad y el caos, una cuestión que obedece a la práctica política concreta y que se repite en varios episodios políticos. Puntualmente se mencionan los debates en las primeras asambleas de piqueteros en el 2001 (junio y septiembre), las jornadas del 19 y 20 de diciembre y por último los debates de mediados del 2002, en los momentos previos al corte del puente Pueyrredón en el que fueron asesinados los militantes Maximiliano Kosteki y Darío Santillán. A nivel general se critica la falta de arrojo y audacia de aquellas organizaciones que privilegiaron de una $u$ otra manera la gobernabilidad antes que la desestabilización, el caos y la crisis. ${ }^{49}$

Aparecen otras críticas de diverso orden y frases de carácter peyorativo hacia otras organizaciones. Se habla de la inmadurez de varios dirigentes -en referencia a Juan Cruz Daffunchio-, de mediocridad e inseguridad ${ }^{50}$, se critica cierto clasismo dogmático de organizaciones trotskistas que no conciben la unión con sectores nacional populares -se menciona al PO y al MST-, se critica la falta de estrategia y la tendencia hegemonizante de "la izquierda" ${ }^{1}$ y por último el sectarismo y la competencia al interior del "campo popular"52. Algunos fragmentos de la publicación Habla Quebracho (Rubio y Del Grosso, 2005) son ilustrativas al respecto:

\footnotetext{
${ }^{49}$ Algunos otros ejemplos de esto son los siguientes:

- "Me acuerdo que el mismo 20 [de diciembre de 2001], mientras moría Petete Almirón en la 9 de julio, nosotros estábamos en la calle peleándonos con la policía, Juan Cruz [Daffunchio] estaba en el programa de Teté Coustarot." (Esteche, 2007)

- "Puente Pueyrredón significa la batalla por la calle y la batalla por la gobernabilidad. Y en esto hay que ser claro. Hubo ausentes a la cita del Puente. Hubo tipos que lo boicotearon... D'Elía, Alderete, Ardura, ellos hicieron una marcha el 25 en contra de la del 26. (...) compraban el argumento del enfrentamiento entre piqueteros, "ellos son los violentos", estigmatizaban y relataban a ese movimiento piquetero con los términos y códigos que habían construido Atanasof, Aníbal Fernández, Juanjo Álvarez. Gran ausente fue el PO. principalmente porque tenían el problema este del calculo político." (Esteche, 2007)

- "Después aparecen estas cosas de: "te corto un carril". (...) Cosas que no están ni mal, ni bien, pero tienen que ver con que cambió. Eso produce una división. Y sectores políticos que jugaron a la gobernabilidad, el CTA en su momento jugó a la gobernabilidad".(Esteche, 2007)

- "[EI PO y el MST] Jugaban y construían escenarios políticos para hacer la actuación, pero la disputa para ellos era en las elecciones, no en la calle. Había un problema de concepción política." (Esteche, 2007).

50 "Hay un nivel de mediocridad en los cuadros dirigenciales del campo popular, terrible." (Esteche, 2007)

51 "La izquierda no tiene estrategia, entonces va construyendo cada 2 años, candidatos, referentes para candidatear." (Esteche, 2007)

52 "Me parece que lo que hay son organizaciones populares que le hacen daño al campo popular. Con el sectarismo, con boicotear las políticas de otros." (Esteche, 2007).
} 
"Nos ha tocado dar la cara en soledad por acciones que desarrollamos
en conjunto con otras expresiones populares que abrigadas por su inseguridad política tiran la piedra pero esconden la mano" ( $\mathrm{p} .17)$

"a diferencia de los políticos pacatos, estamos ofreciendo una salida, un programa político" (p.17)

"Lo que no hacemos es proselitismo, que es el exhibicionismo que hacen las organizaciones electoralistas, que permanentemente se están mostrando para conseguir votos". (p.27)

"Los que nos critican por vanguardistas son quienes se sienten inseguros ante la profundización de la lucha y por eso invierten los términos, atribuyendo a quien tiene iniciativa la responsabilidad por la represión oligárquica”. (p.29)

Aparecen en estas definiciones un distanciamiento con posturas que, sin mencionar organizaciones puntuales, establece lógicas diferenciales principalmente vinculadas a la práctica política, tópico principal que se impone sobre cuestiones más asociadas a matrices ideológicas. En otras palabras podemos señalar que la práctica política, donde el insurreccionalismo posee un lugar significativo, opera como un elemento diferencial, estableciendo límites, de modo más relevante que la orientación ideológica nacional-popular a la hora de caracterizar y ordenar el espacio político que constituye el llamado campo popular.

\subsection{MTD - Aníbal Verón}

Como veíamos en la autodefinición ideológica que nos daba Daffunchio, existe en su discurso una fuerte crítica a muchas de las organizaciones que componen el campo popular, a las que se acusa de sostener un dogmatismo y una rigidez ideológica que atenta fuertemente con las posibilidades de construcción política y articulación.

Cuando le preguntamos al entrevistado sobre aquellas organizaciones con las que se sentía más cercano, mencionó exclusivamente a la CCC-PCR como una organización "amiga" con la que por ese entonces (31 de octubre de 2007) mantenía una relación de cercanía. Aparecen algunas cosas interesantes en esta relación, en la que se reconocen diferencias políticas e ideológicas - de acuerdo a lo que venimos viendo en el análisis de los discursos, estas diferencias son bastantes claras-, pero a la vez destaca su predisposición para hacer política. Así lo sintetiza Daffunchio:

De todo lo que hay, con quienes hemos podido hacer politica nosotros hasta ahora ha sido con los chinos, con los demás no. Estando de acuerdo o estando en desacuerdo. En el marco del respecto y de la unidad. Entonces desde esa óptica es que nosotros tenemos la mejor relación en la actualidad y desde hace un par de años con los chinos, con la CCC, con el PCR. (Daffunchio, 2007) 
En relación a esto es interesante observar la postura de la CCC-PCR mostrando siempre una gran voluntad de articulación en lo que entendemos como un fuerte pragmatismo político que la lleva a desarrollar alianzas y relaciones con casi todas las organizaciones del campo popular, pero que sin embargo lo hace manteniendo un fuerte celo de sus principios y lineamientos ideológicos, es decir sin poner en discusión la propia identidad política en los procesos de articulación. Esto es lo que Laclau y Mouffe señalaban en su distinción entre alianza y articulación política hegemónica -que aquí llamamos de alta intensidad-: sólo en la segunda se pone en discusión los principios sobre los que se construye la propia identidad política. Más adelante volveremos sobre esto.

Sobre las organizaciones de las que se siente alejado se mencionan dos en particular: los trotskistas y los sectores reaccionarios del peronismo. En ambas casos se destaca un punto en común que tiene que ver con aquella rigidez o dogmatismo que se le achaca a muchas organizaciones. El término trotskista opera como un significante que refiere a la rigidez y al dogmatismo, rasgo atribuido no sólo a las formaciones políticas de dicha corriente ideológica, sino también a las diferentes organizaciones que, aunque provienen de corrientes ideológicas muy disímiles, poseen aquellos rasgos. Así lo decía Daffunchio:

\section{$P$ : Organizaciones o partidos del campo popular con los que te sientas menos cercano, más alejado. \\ $R$ : Con todo el trotskismo es con lo que menos identificado nos sentimos. Con los sectores más reaccionarios del peronismo ni que hablar... es lo mismo. Son tan "trotskos" como los trotskistas. Esos peronistas estilo Pérsico que son capaces en última instancia de darle la mano a la derecha con tal de no dársela a la izquierda. Son tan peronistas que se transforman en anticomunistas a veces. (Daffunchio, 2007)}

Lo que se ve con insistencia en el discurso de Daffunchio es la crítica a la inflexibilidad, a la falta de capacidad para trabajar en un plano político sin que se vea abortado a priori por cuestiones ideológicas: "Porque es muy común en el campo popular dividirse hoy por lo que vas a hacer dentro de 20 años. Por si la revolución va a ser insurreccional o popular y prolongada... Por eso hoy con vos no voy a ningún lado... Es muy común eso" (Daffunchio, 2007). En este sentido, las organizaciones trotskistas aparecen como el ejemplo más claro de este tipo de actitudes dogmáticas:

Vos con un trotskista no podés llevar adelante una asamblea, no podés acordar con un plan de lucha, no podés tener cintura política para negociar en un sindicato, no podés nada. Son de izquierda pero están en contra Chávez, de Fidel Castro, ¡Pero por qué no te vas a la puta que te parió! (Daffunchio, 2007)

En la misma línea, así como se habla del "trotskismo" de Pérsico, también se menciona a los trosko-guevaristas y a los trosko-leninistas, todos criticados por su 
dogmatismo o "fundamentalismo ideológico". Una crítica del mismo tipo es la que aparece respecto al MPR-QB cuando se comenta la separación entre la CTD-AV y los grupos que van a conformar el MTD-AV luego de los asesinatos de Kosteki y Santillán, donde se le achaca su falta de flexibilidad para pensar en una convocatoria política más amplia -plural- y la negación intransigente a prescindir del uso de palos y capuchas en las manifestaciones.

Como decíamos, hay una crítica general a cierto dogmatismo de la izquierda en términos generales, y se focaliza en el trotskismo como arquetipo de tal dogmatismo. Se critica, por ejemplo, la postura de responsabilizar al gobierno nacional de todos los males, a partir de una concepción omnipotente y omnipresente del gobierno y del Estado en los asuntos públicos ${ }^{53}$. A modo de autocrítica, como parte de esa izquierda a la que se refiere y en sintonía con la posición que va definiendo, señala:

Mirá si nosotros hubiésemos tenido el poder en algún momento, con cómo somos para dirimir las internas. ¡Otra que Stalin! Con la energía que se pone en la división y con el grado de virulencia política que alcanzan. Imaginate si hubiera poder real en el medio. Hubiera pedazos de ejércitos, pedazos de economía, pedazos de distritos... una sangría... Yo calculo que nos cagamos matando. Otra que la guerra civil española, que fusilaban a uno a cada rato. (Daffunchio, 2007)

\subsection{Movimiento Teresa Rodríguez}

Hay menciones sobre diferentes organizaciones con distintas cargas valorativas a lo largo de las conversaciones que tuvimos con Martino. En estas intervenciones se pueden deducir ciertas posturas generales respecto a las organizaciones pares con las que se piensa futuras articulaciones.

En líneas generales no hay una definición explícita a priori que delimite un sector dentro del denominado campo popular respecto del que haya una cercanía mayor. Cuando le pedíamos una definición sobre eso nos respondía: "tenemos coincidencias con todos. No sé, es muy difícil. No se me ocurre" (Martino, 2007). Ciertamente, cuando exploramos las distintas intervenciones referidas a otras organizaciones y a su relación con ellas, aparece un variado arco, muy sujeto a la circunstancias políticas, que subvierte el esquema lógico que identifica lo ideológico con lo político. Esto es, más allá de sus definiciones ideológicas, las que aparecen formuladas en términos muy concretos y -podemos decir- rígidos, la práctica política se orienta de un modo amplio y -permítasenos el término- pluralista. Esto no significa

\footnotetext{
${ }^{53}$ El comentario es en el marco de las respuestas que se debieran haber producido respecto al secuestro de Jorge Julio López: "Tendríamos que haber sido millones que saliéramos a la calle, en todas partes del país, en defensa de la democracia y punto. Y aparición con vida de López, loco. Esa es la respuesta que tendríamos que haber dado como sociedad ante esas actitudes. Ahora que pasa, el gobierno no, el gobierno la quería capitalizar él, o manejarla de determinada manera. La izquierda ni que hablar, todo es culpa de Kirchner. Una cosa increíble. Se cae un árbol en la autopista y mata un tipo: "porque Kirchner y las privatizadas..." No boludo. Había una tormenta y se cayó un árbol. Ni siquiera tiene la culpa la privatizada. Se cayó un árbol, nada más." (Daffunchio, 2007).
} 
-justamente esta es la hipótesis que atraviesa este trabajo- que, más allá de la voluntad política de unidad y articulación, no operen definiciones político-ideológicas en el sentido contrario.

Entre las valoraciones negativas, aparece en primer lugar el MTD-AV, en particular el sector liderado por Daffunchio, lo que seguramente obedece a la cercanía y al pasado común. Se le achacan dos tipos de errores: por un lado la insistencia de sostener la lógica reivindicativa en la organización, y por el otro la actitud condescendiente o no confrontativa respecto al Estado. Estas críticas son usadas al mismo tiempo para explicar ciertos comportamientos que obedecen a esos límites ideológicos. Es decir, al no superar la lógica reivindicativa, "La Verón" se vio marginada de toda una serie de procesos políticos (como la participación en el Bloque Piquetero) y a la vez la mantuvo alejada del protagonismo en las jornadas de protesta del 19 y 20 de diciembre de 2001.

Otras definiciones que resultan interesantes para tener un pantallazo de la visión sobre las otras organizaciones aparecen en relación a una convocatoria realizada desde la CTA para conformar "un plan de lucha, por una paritaria social". Respecto a este llamado aparece aquella voluntad política de unidad que mencionábamos más arriba, en tanto se reconoce como una posibilidad de construir una alternativa real de alcance nacional. Aquí aparece con gran fuerza el reconocimiento tanto de la CTA como de la CCC como aquellas organizaciones que, "pese a ciertos comportamientos y a sus dirigencias", constituyen las únicas organizaciones del campo popular con alcance y capacidad nacional. Así se refería:

hemos visto en los últimos días con mucha atención el llamado de la CTA. La CTA acaba de hacer un llamado, un plan de lucha, por una paritaria social. (...) solamente se puede pensar, en estas circunstancias de la Argentina, en la construcción de un polo que pueda construir una referencia nacional en la CTA y en la CCC. Ningún otro movimiento tiene esa capacidad y las condiciones para hacerlo. O sea, nosotros vemos que en este proceso, el llamado de la CTA es una esperanza, porque el 2001 solamente fue posible por la lucha contra el menemismo. Por las marchas federales, por los cortes de ruta. O sea, más allá de que critiquemos la inconsecuencia de la dirigencia de la CTA, no podemos dejar de desconocer que en la gestación de la resistencia neoliberal a la política de Menem, tuvo mucho que ver la CTA, la CCC y hasta el MTA. (Martino, 2007)

Luego aparecen toda una serie de referencias de distinto tipo. Sobre Pino Solanas, decía Martino: "Yo creo que Pino es un nacionalista. Es un tipo que cuestiona núcleos del neoliberalismo. No es un enemigo, es un aliado. Es un hombre que tiene prestigio y que mal que mal a mantenido cierta conducta." (Martino, 2007) A modo de crítica, en otro momento y en relación a la convocatoria de la CTA, manifiesta el deseo de que "el grueso de la izquierda la entienda porque por ahí está el tema de 
lo ideológico, que no se entiende, y que termina boicoteando y desperdiciando."54 Finalmente se mencionan toda una serie de pequeñas organizaciones de izquierda vinculadas al movimiento piquetero como aliados en distintos momentos.

Se observa una manifiesta voluntad de avanzar en procesos de articulación política en tanto se reconoce que "solos, nadie puede construir nada". Desde esta base hay una actitud abierta que favorece instancias y espacios de articulación en diferentes momentos de la coyuntura política. Sin embargo, y similar a lo que veíamos en el caso de la CCC-PCR, también se observan algunas definiciones que denotan el establecimiento de límites en las posibilidades de la articulación, producto de la aplicación de definiciones teórico-ideológicas que en última instancia atraviesan -y en muchos casos abortan- las intenciones de unidad. La siguiente "caracterización patológica" de otras organizaciones da un poco cuenta de ello.

\section{P: ¿Considerás que hay organizaciones que dicen ser del campo popular, pero no lo son? \\ $R$ : No yo creo que son del campo popular, lo que pasa es que nosotros diríamos que están enfermas con el virus del reformismo o del populismo. (Martino, 2007)}

\subsection{Barrios de Pie (Libres del Sur)}

La caracterización de las otras organizaciones del campo popular está atravesada por las diferencias ideológicas y los correlatos políticos que venimos observando. Libres del Sur se presenta en este sentido como una izquierda nueva que busca diferenciarse de la izquierda tradicional. El punto de quiebre más importante es aquél en torno a la cuestión nacional, entendida como "el paso previo a consolidar un país con un determinado grado de desarrollo, que permita sobre esa base material objetiva, avanzar a la construcción de una sociedad de otro tipo." (Baigorria, 2007). correlato político en términos históricos se observa en el posicionamiento respecto del peronismo, sobre lo que nuestro entrevistado señalaba que la izquierda "jamás lo supo entender" y que eso la llevó a estar "marginada" a convertirse en "izquierda testimonial" incapaz de "batallar y bregar fuertemente por la disputa del poder concreto y material" (Baigorria, 2007). Por último, esto a la vez se observa en el posicionamiento político coyuntural, ya no histórico, sino presente; es decir respecto del kirchnerismo.

\footnotetext{
${ }^{54}$ Mientras que algunos discursos resaltan la "sobreideologización" en detrimento de "la política" como factor de fragmentación política, Martino destaca que lo que falto fue justamente ideología, en el sentido de contar con un mapa estratégico a largo plazo, un eje ordenador que subordinara el accionar político cotidiano -la resolución de las urgencias- detrás de un planteo ideológico donde se precisaran los elementos más importantes en los que se inscribiera el derrotero político de cada organización. Así lo planteaba Martino: $P$ : ¿Crees que hay o hubo una sobre ideologización en detrimento de cierto pragmatismo político? R: Al revés. (...) nuestra práctica era la urgencia: el comedor, el plan... Yo creo que esto le pasó a la inmensa mayoría... No poder salir de lo reivindicativo. La demanda era tan grande, y nuestra falta de claridad, era tan grande también que terminamos arrastrados en todo esto. Entonces, yo creo que lo faltó fue la ideología. Perdimos de vista eso y fuimos arrastrados a la cuestión de solucionar lo urgente.
} 
De esta manera las otras fuerzas del campo popular aparecen caracterizadas a partir de estos elementos. En líneas generales se critica las dificultades para comprender los procesos políticos concretos y autóctonos, lo que conduce a muchas de ellas a cierto "infantilismo" en sus visiones políticas, que se traduce en plantear alternativas políticas que resultan inviables y a la vez extrañas para la mayoría de la gente. En este sentido señala que "no es un problema de si el discurso nuestro es más bonito. Es un problema de cual es el proyecto que materialmente es aplicable en cada etapa de desarrollo del país, o de una región." (Baigorria, 2007). Para el dirigente la izquierda se refugia en un supuesto "predominio ideológico" que no es tal, ya que se trata de un "predominio ideológico dentro de una gran secta, una gran olla que se cuece sobre sí misma, pero que tiene un fuerte divorcio respecto de la gente." (Baigorria, 2007).

Al interior de la llamada "izquierda tradicional" se distinguen distintas variantes del trotskismo, el Partido Comunista y formaciones como el PCR. Sobre el trotskismo se hace mención a una fuerte tendencia hacia la fragmentación que a la vez es identificada con la vocación hegemónica intrínseca en varias de esas formaciones. Se critican a su vez los planteos orientados en la construcción de "partidos obreristas" que excluyen fuertemente amplias porciones de los sectores medios. Se menciona específicamente al PO, el que es criticado por su histórica vocación hegemonista que clausura todas las posibilidades de confluencia, inclusive al interior del propio espacio trotskista. Del mismo modo se hace una breve mención del Partido de los Trabajadores Socialistas (PTS) al que se reconoce su militancia, su honestidad y buenas intenciones, pero señala que el problema es que "después te los tenés que aguantar". Por su parte el Partido Comunista aparece criticado por las mismas razones que la "izquierda tradicional", pero se destaca cierto proceso de autocrítica por el que ha transitado dicha organización, al punto de pensarla como una aliada inminente en la coyuntura política que se avecina. Por último aparece la CCC-PCR, la organización que encabeza el ranking de las "más alejadas" y sobre la que plantea lo siguiente:

Yo creo que la organización más extraña, que nadie sabe si es o no es, es la CCC y el PCR. Es un misterio. Realmente me siento sumamente alejado de esa organización... A tal punto que ni los conocés. Sabes que están, que existen, pero ni los conocés. Son como toda fuerza, marxistas, son bastante metódicos... Yo me acuerdo cuando se hizo la Marcha Federal,(...) irrumpieron con una marcha muy significativa (...) eran una fuerza realmente envidiable, no la tenía nadie. Ahora no se los ve más. Me parece que es una de las fuerzas de las que uno más alejado se siente. Pero por esa particularidad. En el discurso reivindican lo de Chávez... Pero... es difícil sentirlo como compañeros, porque no están en ningún lado, o no compartimos demasiado con ellos. (Baigorria, 2007). 
Entre las más cercanas aparecen las que coinciden en lo político, las que en la coyuntura comparten el espacio político del Frente Para la Victoria, el que es concebido como un espacio heterogéneo en el que conviven "distintos sectores sociales confrontados en distinto grado con el neoliberalismo precedente" (LS, 2008) y que en la actualidad se enfrenta a las viejas estructuras del Partido Justicialista. Así lo plantea Baigorria, distinguiendo al interior del espacio algunas organizaciones sobre otras y resaltando la dimensión política concreta sobre afinidades ideológicas o conceptuales:

\begin{abstract}
Nosotros hoy nos sentimos cercanos al Frente para la Victoria. Yo te contesto en lo concreto, no en lo romántico. Yo te podría decir que me siento más afín a determinadas formaciones políticas y demás. En lo concreto, estamos hermanados en una lucha contra los intendentes del conurbano bonaerense, allí en esos distritos en los que el Frente para la Victoria se construyó con amplitud, desde el 2005. (...) Ahí hay un espacio que quiere ir por lo viejo y renovar la política. Hay de todo, pero ese es el primer lugar donde nos sentimos hoy más cercanos. (...) Digo el FPV que está enfrentado al PJ. Después hay diversas políticas de alianza. No hay así una fuerza nítida con la cual hoy tengamos más o menos coincidencias. Tenemos más coincidencias siempre con el Frente Transversal, con el Mov. Evita, en algún grado con la FTV también. Pero no son todos partidos políticos. (Baigorria, 2007).
\end{abstract}

\title{
3.9. Otras organizaciones del campo popular: Desagregación de variables.
}

Resuelta interesante observar las diferentes lógicas diferenciales que aparecen en las definiciones y valoraciones respecto a las otras organizaciones que comparten el espacio llamado campo popular. Se observan características diversas y especificidades concretas en el posicionamiento de cada organización a este respecto. Intentaremos comparar la intensidad de la diferencia (la precisión, rigidez y fuerza con la que se designan los elementos diferencian las otras organizaciones de la propia) ${ }^{55}$, la exclusión de subgrupos (el recorte de lo que aquí llamamos el campo popular a partir de criterios ideológico-políticos, más allá de cuestiones circunstanciales), la propensión a alianzas (la predisposición que muestran para desarrollar acciones con otras organizaciones), el criterio de distinción (aquel elemento que sobresale del resto, que opera como límite principal en el señalamiento de la diferencia), el status del otro (el respeto/valoración respecto a los posicionamientos que difieren del propio) y la presencia de juicios éticos o morales (la incorporación de elementos de descalificación ético-morales). Lejos de pretender ser juicios definitivos, estas dimensiones constituyen un intento de sistematización provisoria para ordenar y comparar de mejor modo a las diferentes organizaciones en relación a este punto.

Exclusión Propensión

Criterio de

Status del Juicio

\footnotetext{
${ }^{55}$ Esta variable se extrae fundamentalmente de lo recogido en el apartado anterior.
} 


\begin{tabular}{|c|c|c|c|c|c|c|}
\hline & la diferencia & $\begin{array}{c}\text { de } \\
\text { subgrupos }\end{array}$ & a alianzas & distinción & Otro & $\begin{array}{l}\text { ético } \\
\text { moral }\end{array}$ \\
\hline PO & Alta & $\mathrm{Si}$ & Baja & $\begin{array}{c}\text { Independencia de } \\
\text { Clase }\end{array}$ & Inferior & $\mathrm{Si}$ \\
\hline CcC & Alta & No & Alta & $\begin{array}{c}\text { Antiimperialismo / } \\
\text { Clasismo }\end{array}$ & Inferior & $\mathrm{Si}$ \\
\hline MUP & Baja & $\mathrm{Si}$ & Alta & Kirchnerismo & Inferior & $\mathrm{Si}$ \\
\hline FPDS & Baja & No & Alta & Autonomía & Distinto & No \\
\hline MPR-QB & Baja & No & Alta & Insurreccionalismo & Inferior & No \\
\hline MTD-AV & Baja & No & Alta & Anti-dogmatismo & Distinto & No \\
\hline MTR & Alta & No & Alta & $\begin{array}{l}\text { Reforma vs. } \\
\text { Revolución }\end{array}$ & Distinto & No \\
\hline LS & Baja & No & Alta & Izquierda Nacional & Distinto & No \\
\hline
\end{tabular}

De acuerdo a lo que pudimos observar en nuestra investigación, encontramos en el PO a la organización que establece con mayor intensidad la lógica diferencial que delimita su espacio identitario. Decimos que la intensidad es alta en tanto observamos que aparecen preestablecidos una multiplicidad de elementos ideológicopolíticos que clausuran de antemano posibles articulaciones políticas. En el mismo sentido se excluye un diverso conjunto de organizaciones que son tildadas de no revolucionarias, donde las organizaciones de orientación nacional-popular son señaladas en primer término. Esto se condice con una baja propensión al desarrollo de alianzas con otras organizaciones, en tanto la rigidez de algunos de los lineamientos ideológicos observados se traslada sin mediaciones a la práctica política. En el caso del $\mathrm{PO}$, el criterio de distinción que observamos que actúa con mayor centralidad es el de la independencia de clase: para la organización, el mantenimiento de la independencia de clase como principio de construcción política revolucionaria constituye un elemento innegociable. Decimos que el status del otro aparece como inferior porque consideramos que las referencias a las otras organizaciones poseen una carga peyorativa, siendo descalificadas como no revolucionarias. Finalmente observamos la presencia de críticas que adoptan un cariz ético que acusa a organizaciones de "oportunismo" y de buscar excusas para "ocupar cargos".

En el caso de la CCC-PCR encontramos algunos puntos comunes y algunas diferencias interesantes. En primer lugar, al igual que el caso anterior, consideramos que la lógica diferencial que establece los límites de la propia organización está planteada en términos de alta intensidad; en tanto el modo en que se definen los elementos ideológico-políticos combina una profunda especificidad con una fuerte rigidez. ${ }^{56}$ Sin embargo, esto no deviene en la exclusión de subgrupos ni en una baja propensión a las alianzas. Al contrario, la organización adopta una línea en su táctica política que promueve una multiplicidad de alianzas y acercamientos con las otras organizaciones del campo popular, incluso con organizaciones históricamente

\footnotetext{
${ }^{56}$ Resulta ilustrativo de esto la importancia que adquiere "la lucha contra el revisionismo", uno de los ejes centrales que se delinean desde el PCR. Más adelante volveremos sobre ello.
} 
opuestas a aquel. Entendemos que este comportamiento se vincula con la idea de frente único, que induce a la organización a desplegar una variedad de acercamientos y relaciones en su práctica política. A diferencia de lo que veíamos en el PO, la CCCPCR no traslada la rigidez de sus definiciones generales al quehacer político. Se establece con claridad la distinción entre el corto y el largo plazo, entre la táctica y la estrategia, a favor de lo que podemos llamar un vigoroso pragmatismo político. Por su parte, el antiimperialismo aparece como el criterio de distinción más sobresaliente que, atravesado por el clasismo, termina ordenando el sistema de alianzas. La imagen del otro, de los que no comparten sus lineamientos principales, termina adquiriendo un status de inferior; al menos pareciera desprenderse esa imagen de la autoproclamación como el partido, la vanguardia, la teoría revolucionaria del proletariado... Por último, consideramos que existen descalificaciones que incluyen valoraciones éticas cuando se habla de los "cretinos parlamentaristas" o de los "agentes del imperialismo" presentes en otras organizaciones.

Por el lado del MUP, consideramos que la lógica diferencial que desarrolla respecto a sus organizaciones pares resulta de baja intensidad, en tanto que define sus principales componentes identitarios de un modo general y flexible. De ese modo se construye una frontera permeable que abre la posibilidad para el acercamiento con múltiples organizaciones, aunque circunscripta a determinadas coordenadas políticoideológicas. En este sentido identificamos procesos de exclusión, como sucede en el caso de las organizaciones de la corriente ideológica trotskista. De todos modos, una vez recortado el espacio del campo popular, la propensión a alianzas y acercamientos con otras organizaciones aparece alta, sin demasiados reparos, atravesada, al igual que la CCC-PCR, por un fuerte pragmatismo político. El criterio de distinción más significativo que identificamos es el kirchnerismo, como la encarnación actual de los principales lineamientos de la matriz nacional-popular, y en torno del cual se establecen las posibles alianzas y articulaciones. La valoración sobre aquellos que no comulgan con los lineamientos de la organización, el marxismo en general y el trotskismo en particular, incluye una carga peyorativa, un status de inferioridad. Sin embargo no se apela a juicios de carácter ético como sí observamos en las otras organizaciones.

Respecto del FPDS, consideramos que el "núcleo duro" que establece los límites de su identidad -es decir de su diferencia- puede considerárselo de baja intensidad ya que no encontramos definiciones precisas y rígidas que establezcan fronteras identitarias que resulten impermeables. Las definiciones buscan destacar la forma de construcción política, la importancia de los medios tanto como de los fines, centrándose en la práctica política concreta más que en definiciones a largo plazo. 
Tampoco se excluye ningún subgrupo a partir de definiciones ideológicas y se promueven instancias de acercamiento en un nivel táctico de "coordinación", más allá de las "diferencias estratégicas". Entre los elementos que operan como criterios distintivos es quizás la autonomía la que aparece con más fuerza como eje ordenador delimitador del espacio político. Finalmente, no encontramos en el discurso de la organización descalificaciones peyorativas sobre la otredad-se respeta la diferencia y el disenso- ni críticas que incluyan juicios de carácter ético.

En el caso del MPR-QB entendemos que la intensidad con la que se plantean los rasgos identitarios puede considerársela baja, ya que se observan espacios y aperturas en sus definiciones que denotan flexibilidad. El propio discurso de la organización hace hincapié en priorizar la práctica política antes que las abstracciones ideológicas. En la misma línea, no se observa ninguna exclusión a partir de rasgos político-ideológicos, y se promueven alianzas con sectores de diversos. Sin embargo, si bien la definición de los fines y del rumbo político a seguir ofrece amplitud y flexibilidad, no sucede lo mismo en lo que hace a las formas o los medios: la lógica insurreccional, elemento que -según creemos- termina constituyéndose en el criterio de distinción principal, acaba clausurando muchos de los espacios abiertos por las definiciones ideológicas. Esto último se observa cuando analizamos muchas de las críticas hacia otras organizaciones del campo popular, las que resultan descalificativas y peyorativas, aunque sin incurrir en juicios de carácter ético.

Es en el discurso del MTD-AV donde nos parece encontrar los "mejores indicadores" en relación a las variables que venimos observando. Evidentemente, esto se vincula con el claro énfasis que se pone en la crítica al dogmatismo y a la rigidez de los discursos de la izquierda tradicional: consideramos al "anti-dogmatismo" como principal criterio de distinción. Los elementos en torno de los cuales se establecen las diferencias con las otras organizaciones se presentan de un modo flexible y, lo que es más relevante para nosotros, en proceso de revisión. No hay un proceso de exclusión que se oriente por cuestiones político-ideológicas, aunque aparezcan fuertes críticas al "trotskismo", entendiendo por este, al dogmatismo en general. En este marco se promueven instancias de articulación con otras organizaciones y se resalta la importancia de avanzar en las mismas. Consideramos que el status del otro no aparece como inferior, en tanto que las descalificaciones que se observan son específicamente en contra de la intolerancia respecto de lo diferente, esto es, se resalta la necesidad de la tolerancia respecto a la diferencia. Finalmente, no encontramos en el discurso juicios que pongan en discusión la estatura moral de los referentes de las otras organizaciones. 
El caso del MTR la entendemos como una organización en la que el esquema marxista-leninista aparece con gran centralidad, permitiendo escasas variaciones a las definiciones más clásicas comunes a dicha matriz. El ejemplo más elocuente lo observamos en el modo en que se plantea la oposición entre revolución y reforma. Sin embargo, esto no deriva en la exclusión de subgrupos al interior del espacio "campo popular", ni en una disminución de su propensión a establecer alianzas y acercamientos con las otras organizaciones del campo popular. Tampoco se traduce en una valoración intolerante y descalificadora respecto de las organizaciones de las que difiere política e ideológicamente, ni en juicios de tipo ético-moral.

Finalmente, en el caso de MBP-LS encontramos una construcción identitaria cuyos principales rasgos abren un espacio considerable para, a priori, establecer coincidencias con organizaciones diversas. Pese a las críticas que aparecen respecto a lo que se denomina como la "izquierda tradicional", no consideramos que lleguen al punto de tratarse de exclusiones de subgrupos, en tanto la orientación general de las críticas -al igual que en el caso del MTD-AV- se dirigen contra el dogmatismo. En líneas generales se observa una fuerte propensión a las alianzas, su ingreso a la órbita kirchnerista pareciera responder a ello. Resulta más complejo que en otros casos identificar un criterio de distinción privilegiado que sobresalga sobre el resto. Quizás sea la oposición entre la izquierda tradicional y la nueva izquierda (entendida como izquierda nacional, en tanto intento de incorporar satisfactoriamente los elementos nacionales al paradigma de izquierda) el eje sobre el que más se insiste para establecer distinciones respecto de las otras organizaciones. Por último, el status del otro no aparece con una carga despreciativa ni atravesada por juicios que refieran a su integridad ética.

Resulta interesante cotejar las diferencias que se presentan entre las distintas organizaciones cuando las comparamos en relación a como se ven a sí mismas y entre sí. Encontramos que en algunas organizaciones lo que adquiere mayor peso es el modo en que se definen los fines ideológicos de las propias identidades políticas. En otras, el medio, la forma, resulta determinante. En algunos discursos se excluyen subgrupos, se descalifica la diferencia y se trae a colación la catadura moral de los dirigentes. Creemos que esta breve sistematización nos permite ir acercándonos a una imagen más compleja y completa de cómo actúan los diversos componentes políticoideológicos en las posibilidades de avanzar en procesos de articulación entre las organizaciones del campo popular. 


\section{ENEMIGOS DEL CAMPO POPULAR}

Como venimos señalando la identidad y la diferencia las concebimos como dos caras de la misma moneda: uno es lo que es, en tanto no es otra cosa. Ahora bien, los niveles de identificación son diversos. Por ejemplo, un nivel corresponde a la formación política particular, y otro nivel de identificación es el que opera en el sistema "campo popular". Así como hay rasgos que diferencian una organización de otra al interior del campo, también hay otros que distinguen entre el "campo popular" y aquello que está fuera de él. En este apartado exploraremos el exterior constitutivo del campo popular, es decir las visiones sobre aquellos actores contra los que se oponen las formaciones políticas que aquí integran el campo popular.

\subsection{Polo Obrero (Partido Obrero)}

En este tópico particular, no pudimos obtener respuestas directas y concretas en nuestra entrevista sobre esta formación específica. ${ }^{57}$ Más allá de esto, podemos distinguir algunos elementos que nos permiten construir que exterior constitutivo opera en la conformación del espacio "campo popular" en el discurso de esta organización.

Como veníamos señalando en apartados anteriores, la cuestión de clase aparece con una centralidad excluyente, derivando en una delimitación del espacio social atravesado por la contradicción proletariado-burguesía o clase trabajadora-clase capitalista. Según esta separación primaria y fundamental, el "enemigo" político del campo popular engloba tanto a la clase capitalista, como a sus aliados políticos circunstanciales. De este modo, los proyectos llamados nacionalistas, también terminan siendo incluidos, en tanto aliados de las burguesías nacionales. Como veremos más adelante, las críticas hacia los procesos políticos de Bolivia y Venezuela se orientaban en ese sentido.

Mucho más claro es esto en la caracterización de gobiernos como el kirchnerista, el de Lula, Tabaré Vázquez y Bachelet, gobiernos caracterizados por otros como de centro izquierda o socialdemócratas, en cualquier caso, diferentes a los gobiernos neoliberales anteriores. El caso del kirchnerismo aparece caracterizado como una continuidad de la dominación de "los mismos intereses sociales que estuvieron con Martínez de Hoz y con Menem". Por su parte, los otros gobiernos latinoamericanos son directamente tildados como "eje de la política de dominación norteamericana en América Latina". A nivel local, aparecen incluidos en este campo

\footnotetext{
${ }^{57}$ A diferencia del resto de las entrevistas, la de Néstor Pitrola no logró desarrollarse plenamente, abarcando todos y cada uno de los puntos del cuestionario porque el entrevistado no pudo atendernos más de una hora, es decir, la mitad del tiempo que abarcaron las otras entrevistas. Por tal motivo, sobre este apartado, la información es más incompleta ya que no se pudieron abordar estos tópicos con la exhaustividad que hubiésemos deseado.
} 
formaciones políticas como el ARI, FREPASO, el "binnerismo" o el diputado Claudio Lozano, los que son catalogados como "parte del régimen". (Pitrola, 2007)

Es decir, nos encontramos con una caracterización del "enemigo", del "ellos" al que se enfrenta el campo popular, de gran amplitud en el que se incluyen elementos diversos. Aparece una muy débil -o nula- distinción entre los diferentes actores políticos que no forman parte del "campo popular", todos agrupados a partir de una distinción fundamental y primaria desde un estricto criterio de clase. De esta manera la lógica diferencial que determina el espacio del campo popular se establece en torno a la identidad de clase, restringiendo fuertemente dicho espacio, en tanto toda formación política que subvierta dicha identidad deja de pertenecer al mismo y se convierte, salvo raras excepciones, en enemigo político.

Es decir, aquellas formaciones políticas que no pertenecen al espacio son más bien equivalenciadas en un ellos, amplio y heterogéneo que incluye a todos aquellos actores políticos que no mantienen determinados criterios de independencia de clase en su accionar político.

\subsection{Corriente Clasista y Combativa (PCR)}

Los enemigos del campo popular están definidos en el Programa del PCR (PCR, 2004) en términos generales distinguiendo los siguientes actores: los terratenientes, el imperialismo y la burguesía intermediaria. A eso se le suman "los sectores reaccionarios que se subordinan a ellos", entre los que se destaca a un sector de la llamada burguesía nacional.

Seguido a esto, el Programa pasa a describir como se constituye el Bloque de las clases dominantes en el momento actual en el país (2004). Lo que se observa en la descripción, coincidente con el enfoque que planteaba el coordinador nacional de la CCC en la entrevista, es la preeminencia que tienen "los imperialismos", como hegemonizadores de dicho bloque. Cuando se detallan las características del bloque dominante se parte de la descripción de las potencias imperialistas que en la actualidad lo hegemonizan y explicando el comportamiento político del resto de los actores en función de su relación con las distintas potencias imperiales.

De esta manera, se ofrecen distintas explicaciones sobre el acontecer político y sus diversos actores con una llamativa dependencia de la variable imperialista, que termina explicándolo todo o casi todo. Dicho de otro modo, la perspectiva explicativa ofrece una visión que reduce y subordina fuertemente lo político $-y$ la política ${ }^{58}$ - a lo

\footnotetext{
${ }^{58}$ Hacemos mención a la distinción presente en gran parte de la actual bibliografía sobre teoría y filosofía política que distingue dos espacios políticos, uno fundante y ontológico que refiere al enfrentamiento entre intereses contrapuestos, la disputa de sentidos y la búsqueda de poder para establecer un determinado cierre, es decir, un determinado orden de lo social. La otra dimensión refiere a lo óntico, a la forma de aparición de esas disputas, al escenario institucional, a la administración y gestión de lo social. Autores
} 
económico (en términos generales); mientras que, a su vez, lo económico aparece fuertemente determinado por el tipo de injerencia de las potencias imperiales, la que actúa como variable explicativa predominante, casi exclusiva. No se problematiza sobre una hipotética especificidad de la dimensión política en el ámbito nacional en tanto esta es explicada -en su totalidad- por elementos (doblemente) externos: la dimensión económica y el papel de otros países en dicha dimensión. Señala el programa:

Actualmente la hegemonía del bloque dominante ha pasado a manos de sectores prorrusos y proeuropeos: Techint, Aluar, Clarín, RepsolYPF, Pan American (...); aliados a monopolios, sectores de burguesía intermediaria y terratenientes que integran el cártel cerealero y sojero, a grupos de la construcción, petroleros, petroquímicos y de la alimentación: Cargill, Daw Chemical, (...) Este sector hegemónico del bloque dominante dirige la Bolsa de Comercio, la Cámara del Petróleo, la de Aceiteras, la de Cereales, la de la Construcción, Abappra, etc. (...) Este sector hegemónico domina un poderoso aparato político que controla la provincia de Buenos Aires y la Capital Federal y, con contradicciones, Santa Fe, Córdoba y la mayoría de las provincias, con lo que tiene el predominio en el Congreso. Controla la actual Corte Suprema. Tiene un peso dominante en el aparato sindical. Controla el principal holding de medios de comunicación. Predomina ampliamente en la dirección de la mayoría de las universidades. Controla parte de la "bonaerense" (en donde disputa con sectores proyanquis), de la Federal $y$ de las policías provinciales. Ha dado duros golpes a los sectores proyanquis y menemistas en las Fuerzas Armadas. (PCR, 2004)

Como se ve, en la caracterización del bloque dominante se comienza por señalar cuales con las potencias imperialistas que hegemonizan dicho bloque sectores prorrusos y proeuropeos- y luego se enumeran el resto de los actores, instituciones y espacios de poder que aparecen subordinados casi de un modo lineal. En la misma caracterización aparece luego la descripción del peso y la injerencia del imperialismo yanqui y sus disputas contra las otras potencias imperialistas, señalando:

dirigimos contra el imperialismo yanqui el golpe principal, al tiempo que atendemos a que el sector hegemónico actualmente en el bloque dominante $y$ en el gobierno, contempla en su política lo esencial de los intereses de ese imperialismo y del conjunto de las clases dominantes. (PCR, 2004) El resaltado está en el original

Por su parte, cuando le preguntábamos a Ardura cuáles eran los principales enemigos del campo popular, personajes y organizaciones, mencionaba a Kirchner, Menem y Daer, por un lado y a la Sociedad Rural, la Asociación de Bancos Argentinos (ADEBA) y "de los partidos del sistema" mencionaba al Frente Para La Victoria. Coincidiendo con lo que se plantea en el programa del partido, también la cuestión

como Lefort o Mouffe (2007) denominan a lo primero lo político y a lo segundo la política. Una buena síntesis de esta cuestión verse en Retamozo (2008). 
imperialista tiene un peso determinante y excluyente desde el que subordinan los actores mencionados.

En la entrevista en cuestión aparece con gran centralidad el peso del imperialismo chino, que aparece como aliado fundamental del gobierno nacional y explicando diversos acontecimientos de la política nacional. Un ejemplo claro de esto es cuando explica la política del gobierno nacional respecto a las Fuerzas Armadas (FFAA) como parte de la estrategia del imperialismo chino por desplazar los elementos del imperialismo ruso enquistados en el seno del ejército nacional:

Los chinos son un imperialismo nuevo en el mundo, y por ser nuevo tiene que entrar a los empujones, porque están todas las sillas ocupadas. Es la naturaleza de lo que hace Kirchner. Encontraron el cuadro adecuado para hacer esta tarea: entrar a los empujones. Las fuerzas armadas las han dominado durante 30 o 40 años los generales del núcleo negocista del núcleo pro-ruso. Por tanto, ¿qué quiere hacer este? Hacer mierda las FFAA, bah, hacer FFAA que dominen los que están detrás de él. Entonces vos vas a ver cambios... (Ardura, 2007)

En la misma línea, aparecen figuras y partidos políticos definidos por su relación con determinadas potencias imperialistas. Por ejemplo, señala: "No, entre Kirchner y Macri casi no hay diferencias: los dos son amigos de los chinos" o “¿cómo se juntan radicales y peronistas? Porque son de un mismo imperialismo. Junto un radical de los españoles con un peronista de los españoles." (Ardura, 2007)

Las contradicciones o variaciones que aparecen en el orden político remiten en última instancia a las disputas interimperialistas y a las contradicciones en el seno de las mismas potencias:

Entonces el cuadro es diferente. $Y$ de ahí vienen las contradicciones. ¿Por qué Kirchner jugó con el Tuto Quiroga antes de la elección de Evo? Lógico, porque Bulgueroni está en contra de Evo. Pero Techint dice: no, aliémonos con Evo porque yo hago el gasoducto. Los chinos, están con Evo. Por lo menos los chinos más amigos de los yanquis. Porque hay chinos de tres bandas... (Ardura, 2007)

Esta lógica predomina en todo el discurso político de la organización y es reproducida por el entrevistado ya sea para analizar la crisis de las papeleras o el golpe de estado sufrido por Chávez en el $2002^{59}$, el rol que juegan las potencias

\footnotetext{
${ }^{59}$ Sobre las papeleras señala: "Porque los rusos que están detrás de Tabaré, no son los mismos rusos que en Rusia son amigos de Kirchner en la Argentina. Son los mismos los que están detrás de Tabaré, que están detrás de Duhalde y Alfonsín. Por eso todos los candidatos opositores a Kirchner estaban en contra de la lucha de los ambientalistas de Gualeguaychú. Lógico. ¿Por qué? Porque están a favor de Botnia y de los rusos que están detrás de Botnia. Porque los finlandeses siempre fueron un país asociado a los rusos. Hasta de Lenin fueron asociados".

Respecto al golpe a Chávez analiza: "Supongamos que Chávez es un buen ciudadano, es un burgués nacional, antiimperialista, bárbaro, muy bien. Yo lo apoyo. La lucha del pueblo venezolano pa, pa pa. Pero tiene socios. No todos los imperialismos están en contra de Chávez. Ya se vio en el golpe de Estado, sólo los yanquis y los españoles participaron en el golpe. Los holandeses que están en Venezuela, no estuvieron en el golpe. Apoyaron a Chávez, no solo fue el pueblo... los chinos no estuvieron en el golpe contra Chávez. Un sector de los rusos no estuvo en el golpe contra Chávez. Es decir las ecuaciones de esa multitud de imperialismos que apoyan o están en contra de un gobierno son
} 
imperialistas es determinante y pareciera agotar, al menos en su aspecto sustancial, las explicaciones al respecto.

\subsection{Movimiento de Unidad Popular (MUP)}

Para el MUP los enemigos del campo popular son los sectores que se oponen al proyecto nacional y popular, aquellos grupos concentrados de la economía que obstaculizan los procesos de distribución de la riqueza y de intervención estatal. En este sentido no aparece la burguesía como un sujeto social necesariamente antagónico, sino que puede formar parte del bloque nacional si apuesta al mercado interno, a la generación de empleo, si acepta las exigencias de redistribución que el Estado le pueda imponer, etc. Es decir, la figura del empresariado nacional aparece en la matriz nacional-popular como un aliado estratégico, no circunstancial, del proyecto político emancipador.

El modelo de capitalismo nacional con inclusión social incorpora una variedad de actores que exceden los moldes del esquema de clases dicotómico de raíz marxista. Sin embargo se mantiene una misma lógica que opera en ambos casos: por un lado los sectores que abogan por el bienestar de las mayorías, de los más desprotegidos, de la clase trabajadora y por el otro todos los sectores que prefieren un modelo de país basado en el libre mercado y en la reducción de las facultades intervensionistas y redistributivas del Estado.

Cuando le preguntábamos a Martelli sobre los enemigos del campo popular aparecieron las figuras de Macri, Sobisch y Blumberg en el plano político, periodistas como Joaquín Morales Solá, Fontevecchia y en un escalón inferior Longobardi y González Oro quienes les parecían graciosos pero "que tienen su llegada". En cuanto a aquellas organizaciones perjudiciales para los intereses del campo popular, aparecen mencionadas la Sociedad Rural Argentina, la Asociación de Empresarios de la Argentina y la Asociación de Bancos (Martelli, 2007). Como puede verse, tanto los personajes como las organizaciones remiten a emblemáticas figuras de lo que la mayoría de las formaciones políticas del campo popular, identifican como contrarios a los intereses de los sectores de menores recursos.

Del mismo modo también aparecen señalados tanto el Partido Justicialista como la Unión Cívica Radical, los que son criticados, no como necesarios enemigos, representantes naturales de los intereses de la burguesía, etc., sino porque ambos partidos fueron hegemonizados por los sectores dominantes de la economía, abandonando sus luchas históricas y objetivos originales. ${ }^{60}$ Así lo dice:

diferentes en cada uno de estos gobiernos".

${ }^{60}$ Es el mismo planteo que hace Maristella Svampa (2005) en La sociedad excluyente, específicamente en capítulo 2 "Mutaciones de la política y modelo de dominación". 
Llegó un momento en que las clases dominantes ganan la conducción de los 2 partidos y ahí empieza la crisis. Porque ya no representan cosas distintas, representan lo mismo. Eso desencadena una crisis de representación. Hasta ese entonces no tenían partidos, tenían que recurrir a los militares y a la iglesia. De repente tienen dos, no uno. Uno hace una cagada primero, el otro después hasta que se agota ese esquema. (...)

Uno de los principales temas de la oposición es como Kirchner bastardea a los partidos. Tanto los radicales como el PJ quieren que esas estructuras sobrevivan porque es la forma para que las clases dominantes sigan alternándose en el poder. (Martelli, 2007)

Es clara la distinción que establece el entrevistado entre el PJ y el Frente Para la Victoria, como estructuras políticas que representan intereses diferentes y en claro enfrentamiento, distinción desatendida por otras visiones que no consideran relevante establecer dichas diferencias en tanto se considera que las cosas en común prevalecen.

Como salta a la vista la diferencia central entre la caracterización de los enemigos gira en torno al posicionamiento respecto al kirchnerismo. Hay un consenso generalizado en reconocer en sujetos como Macri, Blumberg y Sobisch o en organizaciones como Sociedad Rural, Adeba, etc, a los enemigos de los intereses de los sectores más desprotegidos. La diferencia que es central, es la visión y postura respecto al kirchnerismo, el que es presentado por unos como el principal representante de los intereses de la clases dominantes, como un enemigo central; mientras que para el MUP es visto como el espacio político más sobresaliente capaz de poner freno, en las condiciones actuales, a los sectores más reaccionarios y poderosos de la sociedad. Hacia el final nos meteremos a explorar esta cuestión de modo específico.

\subsection{Frente Popular Darío Santillán}

Los enemigos del campo popular que identifica el FPDS concuerdan con los que señalan la mayoría: en primer lugar los grandes grupos económicos de las diversas áreas ya sean nativos y extranjeros y una especial mención de las empresas privatizadas, de quienes hoy gerencian dichas empresas. También se nombra de manera explícita a de los partidos políticos tradicionales (PJ y UCR), elementos del Estado (aparato judicial y de seguridad) y por último una mención a los grandes medios de comunicación. Así lo señala Obregón en la entrevista:

$P$ : ¿Cuáles son las fuerzas/actores que representan los intereses más perjudiciales para el campo popular en general?

R: Por supuesto las grandes empresas privatizadas, telefónica, Repsol. Petrobrás. Los grandes terratenientes vinculados al cultivo de la soja. Los grandes grupos financieros. Los grupos empresariales nativos, que muchos de los cuales actúan en política también. Después hay un conjunto de aliados y colaboradores: los partidos políticos del sistema - 
el PJ principalmente y el radicalismo. El aparato judicial, la policía bonaerense y las fuerzas de seguridad en general. La prensa, los grandes medios. (Obregón, 2006)

Cuando le preguntamos sobre personajes concretos también aparecieron figuras conocidas sobre las que hay un relativo consenso a la hora de identificarlos como "caras visibles" de la derecha o del campo anti-popular. Así aparece en primer lugar la figura de Mauricio Macri, caracterizado como "uno de los más peligrosos" por su juventud y proyección luego del triunfo electoral en la ciudad de Buenos Aires. Luego vienen otros conocidos como Hadad, López Murphy y Sobisch, todos personajes emblemáticos de la derecha autóctona.

Hay una clara delimitación del espacio de la derecha, diferenciado de otros actores que sin ser enemigos, están lejos de arrancar simpatías. Un caso de ese estilo lo constituye el kirchnerismo y sus aliados, sobre el que avanzaremos en el próximo apartado.

\subsection{MPR-Quebracho}

Al interior de la dicotomía "Patria vs. Entrega", la organización sintetiza a los enemigos del campo popular en el imperialismo y el gran capital. Luego se enumeran cinco categorías que buscan precisar más aún la definición original: a) los grandes monopolios financieros, b) los organismos multilaterales de crédito (BM, FMI, BID), c) los estados imperialistas -se mencionan como ejemplos a E.U., la Unión Europea, Japón e Israel-, d) las oligarquías nativas y e) grandes grupos económicos nacionales (se menciona a Pérez Companc, Macri, Rocca, Fortabat y Pescarmona). (Rubio y Del Grosso, 2005:21)

Esta categorización identifica los poderes últimos, los verdaderos enemigos del campo popular, mientras que luego se describen quienes son los instrumentos de esos poderes en nuestro país, aquellos que instrumentalizan la dominación ejercida en última instancia por aquellos. Los instrumentos locales son "la clase política y sus partidos, las Fuerzas Armadas y de Seguridad, el Poder Judicial, y la Gran Prensa" (Rubio y Del Grosso, 2005:22). Como se ve, se aplica una perspectiva de orientación marxista en la que se identifican a los principales representantes de la dominación económica y luego se presentan los instrumentos que finalmente gestionan y ejercen la dominación.

Una diferenciación similar aparece en la entrevista que le hicimos a Esteche para este trabajo en la que respondía lo siguiente:

\footnotetext{
P: Decime 3 personajes que para vos representen el campo antipopular.
} 
R: Hay dos niveles. Una son la clase y otros son los gerenciadores de esa clase. Los gerenciadores de la clase por ahí van y vienen, porque son gerentes.

$P$ : Decime 3 gerentes

R: Tranquilamente, ha sido Menem, De La Rúa y Kirchner. De los 3 últimos tenés esos. Ahora el campo antipopular no son Menem, De La Rúa y Kirchner. Son Paolo Rocca de Techint, son Bulgueroni, que ahora están con Panamerican Energy, esos son... los Monsanto, esos son los verdaderos enemigos. Los otros... no existen, realmente no existen, son actorcitos. (Esteche, 2007)

En ambos casos hay un sector económico que constituye la dominación en el plano estructural y una serie de actores e instituciones políticas que en el plano superestructural aseguran tal dominación. No se observan demasiadas mediaciones entre una dimensión y otra, ya que se plantea el esquema de manera casi automática y englobando una variedad de actores que a partir de la propia perspectiva de análisis aparecen determinados a priori en su accionar político. Sería interesante ahondar sobre las mediaciones y contradicciones que pueden existir al interior de los actores mencionados y los diferentes tipos de relación que se pueden establecer entre unos y otros. Hoy veíamos que aparecían figuras como Mario Cafiero o Claudio Lozano valorados positivamente. La pregunta para profundizar el análisis sería ver quienes constituyen la clase política y cuáles son sus partidos, quienes no, etc. Es decir complejizar y poner en discusión algunas determinaciones que terminan subordinando totalmente la esfera de lo político a lo económico.

\subsection{MTD - Aníbal Verón}

No hay una identificación precisa y plena de quien encarna el status de enemigo del campo popular, aunque sí hay menciones sobre algunos personajes que permiten trazar algunos rasgos generales. Cuando le preguntamos a Daffunchio sobre los personajes que representaban a los enemigos del campo popular nos señaló tres personajes bastantes disímiles desde el punto de vista político e ideológico: Elisa Carrió, Juan Carlos Blumberg y Roberto Lavagna. Más allá de sus diferencias estos tres personajes son equivalenciados como representantes de los enemigos del campo popular, cada uno desde su lugar. El caso de Blumberg aparece señalado como un intento de la derecha más radical de organización de una fuerza política. El caso de Carrió no es tan claro, de hecho aparecía como una posible aliada cuando Daffunchio comentaba la necesidad de armar una convocatoria amplia en respuesta a los asesinatos de Kosteki y Santillán en julio de 2002. El caso de Lavagna no aparece desarrollado y no permite demasiadas reflexiones.

En líneas generales vemos tres personajes de gran visibilidad mediática, que aunque Carrió y Lavagna no sean arquetípicos representantes de lo que 
habitualmente se asocia a los enemigos del campo popular- constituyen actores políticos de relevancia y potencialidad concreta. En consonancia con lo que venimos observando en el discurso de este dirigente político, notamos una perspectiva que da centralidad a la cuestión política concreta, al escenario coyuntural y a los personajes que se destacan en ese aspecto.

Aparte de estas tres menciones, se destaca el papel de los grandes medios de comunicación como un actor de gran relevancia como enemigo del campo popular. En particular se habla del Grupo Clarín, como el máximo exponente de esta categoría y se destaca el papel y la autonomía de los mismos. A diferencia de otros planteos que hemos visto, los medios no son una prolongación ininterrumpida de un poder superestructural en el que los grandes poderes imperialistas, los grandes grupos económicos, los gobiernos locales y los grandes medios de comunicación constituyen un todo casi indiferenciado. En sintonía con la perspectiva gramsciana ${ }^{61}$, Daffunchio evita caer en simplificaciones, destacando las complejidades de lo superestructural, resaltando diferencias y contradicciones -en este caso- entre el Estado (y sus gobiernos de turno) y los grandes medios, atados cada uno a intereses particulares. ${ }^{62}$

Por último se menciona a la figura de Castells, no cómo un "enemigo del campo popular", pero sí como funcional a sus intereses: "De nuestro lado, alguien que es funcional al enemigo, es Castells, por ejemplo. Ese es funcional a la estrategia del enemigo." (Daffunchio, 2007). De aquí resulta interesante el doble aspecto de "perteneciente a nuestro lado" y a la vez la "funcionalidad al enemigo del espacio". Deducimos que esta ambigüedad obedece a una práctica equívoca, pero no a una intencionalidad orientada en contra de los intereses políticos del campo popular.

\subsection{Movimiento Teresa Rodríguez}

Cuando le preguntamos a Martino sobre los personajes más representativos del campo antipopular se desagregaron tres ámbitos distintos: la política, los medios y el mundo empresarial. Dentro del ámbito político aparece mencionado Néstor Kirchner, su esposa Cristina Fernández, Mauricio Macri y López Murphy. Del lado de los medios se menciona a Mariano Grondona, Rosendo Fraga y Horacio Verbistsky. Por último, se

\footnotetext{
${ }^{61}$ Entre los aportes que suelen destacarse de la densa y asistemática obra de Antonio Gramsci, aparece su empeño por resaltar las diferencias -y especificidades- que puedan identificarse al interior de la superestructura de cada bloque histórico. En este sentido adquiere especial importancia la distinción entre Sociedad Política y Sociedad Civil. Quien trata especialmente esta cuestión es el trabajo de Carlos Pereyra, "Gramsci: estado y sociedad civil",en Zona Abierta N 48/49, 1988.

62 El comentario completo es el siguiente: "Una de las cosas que se comentan es que Clarín le está empezando a pegar al gobierno porque quieren el monopolio del cable y todo eso y no se lo da. De hecho, Clarín estaba endeudado y no podía pagar, estaba en default técnico y necesitaba la devaluación. Clarín fue parte de los grupos que apuraron la caída de De La Rúa. La masa participó de eso, por supuesto, pero no fue el único protagonista. No está tan loco De La Rúa cuando dice, a mi me voltearon, a mi me voltearon. Le hicieron flor de cama a De La Rúa. Y Clarín participó de todo eso. Entonces, enemigos del campo popular... muchos, muchísimos." (Daffunchio, 2007)
} 
nombra entre los empresarios a los Rocca, Soldatti, Bulgueroni, Pescarmona y los representantes de oligarquía tradicional Menéndez Beti y Anchorena. Por último cuando lo consultamos sobre fuerzas, se mencionaron al partido que lidera Macri, el PRO, y luego al "partido de López Murphy, el de Sobisch y el de Romero en Salta".

Como puede verse hay una construcción del enemigo del campo popular que incluye referentes de espacios políticos divergentes y en franca oposición. En efecto, al igual que veíamos en discursos anteriores, Kirchner, su esposa y su entorno -en este caso la figura de Verbistsky- son identificados claramente y en primer lugar como fieles representantes del campo antipopular, estableciendo un radical desencuentro con aquellas organizaciones contaminadas por el "virus del populismo" cercanas a dicho sector político.

Este sector del oficialismo es acompañado por figuras ya más conocidas y arquetípicas de los sectores dominantes de la economía y de la derecha en términos políticos e ideológicos. De esta manera, personajes que aparecen fuertemente enfrentados en el pasado y en la actualidad como Verbistky y Grondona aparecen homologados en el espacio de los enemigos del campo popular, junto con los representantes del gran empresariado autóctono y los referentes de los partidos más claramente referenciados en el espectro de la derecha.

Esta enumeración que termina equivalenciando estos actores en otro momento desaparece cuando se habla de "la agenda de las clases dominante" y en la que se mencionan a personajes y organizaciones de lo que llamamos arquetipos de la derecha, cuya "agenda" a su vez se opone a muchas políticas oficiales, lo que pareciera traer algún tipo de complejidad o contradicción a la categorización que vimos hasta aquí. Así lo decía Martino:

"las clases dominantes sí están planteando una agenda de cambio, de
giro conservador. Uno lo lee a Macri, lee el discurso de la Sociedad
Rural, lee el coloquio de IDEA, el encuentro de los amigos de la
fundación de Tel Aviv, lee a Grondona, lee las declaraciones de las
cámaras empresariales... y todos coinciden en que la Argentina debe
reinsertarse en el mundo. Lo cual implica pagarles a Paris, que el fondo
siga monitoreando la economía, todos coinciden que hay que acabar
con las retenciones, todos coinciden con que hay que liberar las tarifas...
O sea, los sectores dominantes, tienen una agenda." (Martino, 2007)

En el siguiente apartado seguiremos con la caracterización del kirchnerismo. Para concluir este, vale destacar esta composición de los enemigos del campo popular en la que conviven referentes del kirchnerismo con los arquetipos de la derecha. Se revela el peso determinante que adquiere el posicionamiento político concreto, sobre todo en el caso de Verbitsky, quien previo a su opción por acompañar el proyecto kirchnerista -como lo han hecho otros referentes del campo popularhubiese estado lejos -creemos- de ser ubicado entre los enemigos del campo popular. 
La lógica equivalencial que agrupa a los diversos actores en el campo enemigo, y que a la vez delimita el propio campo, aparece un tanto cuestionada por el propio discurso cuando se arriba a una caracterización como la de la agenda de la clase dominante. La pregunta que nos hacemos es: ¿Si avanza la "agenda la clase dominantes", no lo hace, en gran parte, en oposición al kirchnerismo, primer actor mencionado como representante del campo antipopular?

\subsection{Barrios de Pie (Libres del Sur)}

Cuando preguntábamos sobre los representantes del campo antipopular surgieron dos grandes dimensiones que resultaron relevantes para el entrevistado, el ámbito político y el de los medios de comunicación. Dentro del ámbito político surgen tres grandes grupos con sus referentes sobresalientes que son Mauricio Macri, el "PJ anti K" y el sector que encabeza Elisa Carrió. En orden de importancia, la figura de Macri aparece en primer lugar y es concebido como "el principal oponente por venir", en tanto se lo caracteriza como una figura en ascenso, con perspectivas y como la posible "cabeza" de un frente tras del cual se encolumnarían otros referentes de la "derecha política", incluidos sectores del peronismo. El grupo del "PJ anti K" es el que para las elecciones legislativas de 2007 encabezó la figura de Alberto Rodríguez Saá en el que confluyeron diversos personajes conocidos, entre ellos, una porción significativa del viejo menemismo, pero también sectores asociados al caudillo bonaerense Eduardo Duhalde. Según Baigorria muchos de los que componen este grupo podrían encolumnarse tras la figura de Macri. En tercer lugar -y en ese orden de importancia- aparece la figura de Elisa Carrió, quien aparece representando "una variante de centro izquierda engañosa", pero que no termina de constituirse en una opción política amenazante ya que "se presenta como una mujer emocionalmente inestable". (Baigorria, 2007)

En segundo lugar hay una mención de los referentes antipopulares de los medios de comunicación, entre los que se menciona a Mariano Grondona en primer término y a Joaquín Morales Solá. Del primero destaca su larga trayectoria como "cuadro de la derecha", reconociendo tanto su inteligencia como su peligrosidad. Del segundo se hace mención al llamativo ensañamiento que desde sus editoriales de La Nación y sus programas de TV descarga sobre el kirchnerismo. (Baigorria, 2007)

Tanto en la dimensión política como mediática, se trata de representantes de los intereses de las clases dominantes, las que son definidas económicamente, como aquellos "sectores concentrados" que abogan por determinado orden político y económico. Son estos sectores los que respaldan y están detrás de estas figuras políticas y mediáticas, y son los mismos que bregan por "recuperar los partidos 
tradicionales, y en especial al PJ con su vieja dirigencia, para manejar sin demasiados sobresaltos la nueva etapa" (Baigorria, 2007).

En resumen, hay una caracterización del campo antipopular en términos eminentemente políticos, destacando a las figuras, cuadros y operadores que de uno $u$ otro modo están tras las representación de los intereses de clases dominantes, que siguiendo una perspectiva materialista, están constituidas por los sectores más concentrados de la economía. Baigorria destaca que la competencia es esencialmente política, y se trata de evitar que los representantes políticos de los sectores dominantes logren hegemonizar y refundar las viejas estructuras políticas de los partidos tradicionales.

\subsection{Enemigos íntimos}

La caracterización de lo que se considera como los representantes del campo anti-popular reproduce algunas de las distinciones que venimos observando hasta aquí. A primera vista salta un eje distintivo que tiene que ver con el posicionamiento concreto en relación a la coyuntura política, en definitiva, en relación al kirchnerismo. Tal es la importancia que, si se observa el cuadro, constituye el único elemento que genera desacuerdos en relación a este punto.

\begin{tabular}{|c|c|c|c|}
\hline \multicolumn{4}{|c|}{ Enemigos del campo popular } \\
\hline & Política & Comunicación & Empresa $^{63}$ \\
\hline PO & Kirchner & Sin datos & Clase Capitalista \\
\hline PCR & Kirchner, Menem, Daer, FPV & Sin datos & SRA, ADEBA \\
\hline MUP & Macri, Sobisch, Blumberg & $\begin{array}{l}\text { Morales Solá, } \\
\text { Fontevecchia, } \\
\text { Longobardi } \\
\end{array}$ & SRA, ADEBA, AEA \\
\hline FPDS & $\begin{array}{l}\text { Macri, Sobisch, López Murphy, } \\
\text { PJ, UCR, Aparato judicial y } \\
\text { represivo }\end{array}$ & Hadad & $\begin{array}{l}\text { GGE, Privatizadas, Terratenientes } \\
\text { sojeros, GGF, Grandes Medios }\end{array}$ \\
\hline MPR-QB & Menem, De la Rúa, Kirchner & Sin datos & $\begin{array}{l}\text { GGF, Org. Multilat. de Crédito, } \\
\text { Estados imperialistas, Oligarquías } \\
\text { nativas, GGE locales }\end{array}$ \\
\hline MTD-AV & Carrió, Lavagna, Blumberg & Grupo Clarín & \\
\hline MTR & $\begin{array}{ll}\text { Kirchner, Macri, } & \text { López } \\
\text { Murphy, } & \\
\text { MPN (Sobisch), } & \text { Romero } \\
\text { (Salta) } & \\
\end{array}$ & $\begin{array}{l}\text { Grondona, Fraga, } \\
\text { Verbistsky }\end{array}$ & $\begin{array}{l}\text { Rocca, Soldati, Bulgueroni, } \\
\text { Pescarmona, Menéndez Beti, } \\
\text { Anchorena }\end{array}$ \\
\hline LS & Macri, Carrió, "PJ anti K" & $\begin{array}{l}\text { Grondona, Morales } \\
\text { Solá }\end{array}$ & \\
\hline
\end{tabular}

63 Siglas: FPV: Frente Para la VictoriaI, PJ: Partido Justicialista, UCR: Unión Cívica Radical, SRA: Sociedad Rural Argentina, ADEBA: Asociación de Bancos de la Agentina, AEA: Asociación de Empresarios Argentinos, GGE: Grandes Grupos Económicos, GGF: Grandes Grupos Financieros. 
Aquella distinción que observábamos respecto a las autodefiniciones ideológicas se corresponde con la inclusión o no del kirchnerismo como enemigo del campo popular: en las cuatro organizaciones que se definen al interior de la matriz marxista-leninista, Kirchner es mencionado como uno de los principales enemigos del campo popular. Entre las restantes, por un lado está la línea del FPDS y del MTD-AV, las que sin callar críticas y manteniéndose distantes del kirchnerismo, no lo consideran entre los principales representantes del campo anti-popular. Por el otro lado, mucho más claro, en el MUP y en MBP-LS hay una adhesión y un respaldo al kirchnerismo, que reordena el escenario y establece enemigos ausentes en otros discursos (por ejemplo el "PJ anti- K"). Sobre el resto de los actores y fuerzas mencionadas en cada una de las dimensiones escogidas pareciera existir un consenso generalizado.

Cabe señalar que en todos los casos se caracteriza el escenario político desde una perspectiva más o menos atravesada por el materialismo histórico. Nos referimos al hecho de que en la descripción y elección de los enemigos políticos, adquiere gran centralidad la esfera de lo económico, la que con mayor o menor incidencia, aparece siempre presente en el escenario de lo político. En algunos casos más explícitos que en otros, todas las organizaciones dan cuenta de que los verdaderos enemigos son las clases dominantes (económicas), mientras que las distintas fuerzas y actores del ámbito político -y comunicacional- constituyen sus representantes o gerenciadores. Los desacuerdos surgen cuando se pasa al análisis político concreto y creemos que el modo en que se concibe la relación entre la dimensión económica y la política puede constituir un factor relevante en aquel análisis.

Las organizaciones de la matriz marxista-leninista ven en Kirchner a un claro enemigo del campo popular, el gerenciador de turno de los intereses de las clases dominantes, igual o peor que cualquiera de los presidentes de los últimos 25 años. Se desestiman las diferencias y cualidades que destacan quienes lo apoyan, como pura cosmética. Las disputas entre el kirchnerismo y sectores comúnmente llamados de derecha (Macri, Sobisch, López Murphy, SRA, etc.,) son consideradas como meras disputas interburguesas o interimperialistas. Se traslada el radical antagonismo entre burguesía y proletariado a la esfera de la política, constituyendo dos bloques casi indiferenciados, en los que no se observan -o carece de relevancia enunciarlasdiferencias significativas al interior de cada bloque: "Los intereses que gobiernan son los mismos".

Del lado de las organizaciones de la llamada izquierda heterodoxa no se lo incluye a Kirchner como representante de los enemigos del campo popular, aunque también se está lejos de considerarlo un aliado. Se lo considera un actor político al que se le deben achacar toda una serie de críticas, pero que a la vez deben reconocérsele 
algunas virtudes. ${ }^{64}$ Esto se apoya en una perspectiva que le otorga a la dimensión política lógicas propias que flexibilizan el esquema de base y superestructura. En esta línea el cuadro de los enemigos del campo popular queda reducido a figuras emblemáticas de la derecha política e ideológica y a los grandes actores que predominan en el ámbito de lo económico.

Entre las organizaciones de la matriz nacional-popular, el mapa de enemigos se acerca claramente al de estas últimas. Las figuras arquetípicas de la derecha política y mediática se suman a los grandes poderes económicos para completar el grueso del cuadro. Hay una especial focalización en los sectores tradicionales del Partido Justicialista, identificado como un espacio crucial en el proceso de avance en contra de los sectores del campo anti-popular.

En líneas generales podemos destacar que el punto diferencial más significativo en relación a los enemigos del campo popular, obedece a la coyuntura política y remite a la inclusión o no del kirchnerismo en dicha categoría. Creemos que el modo en que se concibe la relación entre lo económico y lo político deriva en perspectivas que establecen mayor o menor diferenciación y gradaualidad en la caracterización del escenario político. Esto, a la vez, deriva en las modalidades que adquiere la articulación política. Resulta interesante cotejar que si el criterio de distinción es el del apoyo al kirchnerismo, quedan aisladas el MUP y MBP; pero si el criterio es su inclusión en el campo antipopular, la taxonomía coincide con la que distingue a las organizaciones marxistas-leninistas de las que no. En la caracterización que las organizaciones hacen del kirchnerismo avanzaremos en el análisis.

\footnotetext{
${ }^{64}$ En el siguiente apartado profundizaremos sobre esto.
} 


\section{COYUNTURA POLÍTICA: CARACTERIZACIÓN DEL KIRCHNERISMO}

Uno de los elementos que orientó y motivó la presente investigación fue el significativo cambio que produjo la asunción a la presidencia de Néstor Kirchner el 25 de mayo de 2003 en relación a las instancias y posibilidades de articulación política al interior de lo que venimos denominando el campo popular. En efecto, es por todos conocido, el hecho de que la presidencia de Kirchner provocó un fuerte reposicionamiento del conjunto de las formaciones del campo popular, principalmente debido a que, a diferencia de gobiernos anteriores como el de Carlos Menem o el de Fernando De La Rúa, el gobierno de Néstor Kirchner -y en gran medida el de Cristina Fernández- no agrupó al conjunto de las formaciones del campo popular en oposición suya. Al interior de este campo encontramos diversos tipos de posiciones en relación al kirchnerismo que van desde un fuerte involucramiento (FTV, Mov. Evita, MUP), hasta una franca oposición (PO, CCC). Al medio aparecen posturas que oscilan entre uno y otro polo.

El objetivo de pensar el campo popular como un conjunto de formaciones que confluyeron en momentos anteriores -claramente desde mediados de la década de 1990 hasta el estallido de diciembre de 2001- en la oposición a determinado enemigo común, nos permite observar hoy un universo fragmentado por la valoración y el posicionamiento respecto al kirchnerismo. En este apartado buscaremos describir los posicionamientos de las diversas formaciones en relación a este tópico, observando puntos en común y disidencias.

\subsection{Polo Obrero (Partido Obrero)}

Como hemos venido viendo, el PO es un claro y consecuente opositor del kirchnerismo. En el apartado anterior observamos que las muchas de las diferencias en relación a otras formaciones estaban zanjadas por la posición respecto al gobierno. Así aparecen aquellas organizaciones oficialistas, las que son vistas como cooptadas, absorbidas por el poder del gobierno. Al transformarse en aliadas o en parte constitutiva del gobierno, estas organizaciones son vistas como enemigos políticos. Del mismo modo, existe otro subgrupo de organizaciones que son acusadas, no ya de ser aliadas o parte del gobierno, si no de no ser lo suficientemente opositoras. Este el caso de la CCC, el MTD Aníbal Verón y el MTR de Martino.

El gobierno de Kirchner es para Pitrola un gobierno aliado y representante de intereses de grandes capitales nacionales y transnacionales. Su proyecto de país, es visto a la vez como regresivo y fuertemente desfavorable para los intereses de la clase trabajadora. 
Sin duda, el gobierno kirchnerista, que se ha colocado como un representante argentino de los vientos de autonomía nacional y de adaptación a las rebeldías populares que corren en América Latina, ha podido reconstituir el Estado y ha podido insertar a la burguesía argentina en estos años de ciclo económico internacional favorable, lo cual le dio las condiciones para pilotear una salida en términos capitalistas. A expensa de los trabajadores, ha puesto en marcha un crecimiento económico con una fuerte desigualdad social, de fuerte trabajo en negro, de fuerte superexplotación, de una situación muy crítica de la juventud trabajadora, de una prolongación de la flexibilidad laboral de los años 90; no obstante lo cual, el gobierno kirchnerista asienta una dominación en términos muy distintos a los del menemismo. (Pitrola, 2007) El subrayado es nuestro

De este modo el gobierno aparece caracterizado en primer lugar como "una salida capitalista" a la crisis de 2001-2002, salida que a la vez está orientada en detrimento de la clase trabajadora. Aparece aquí con fuerza la cuestión capitalismo/no capitalismo, disyuntiva que aparece con fuerza cuando procesos políticos como los de Venezuela o de Bolivia también terminan confluyendo, aunque con sus diferencias, en el mismo todo capitalista. El otro punto que se destaca es el perjuicio del que es víctima la clase trabajadora, que enmarcada en la dicotomía trabajo-capital, el resultado de la ecuación sólo presenta dos respuestas posibles: o se está con el trabajo, con la clase trabajadora, o con el capital. Finalmente, cuando el entrevistado distingue los términos de la dominación kirchnerista de los que operaban en el menemismo, señala especialmente la política de cooptación que ya venimos comentando como un rasgo central atribuido a la nueva dominación kirchnerista.

Respecto al modelo económico y a su estrecha vinculación con los grandes capitales y la burguesía nacional, señala lo siguiente

Es un esquema que está atravesando contradicciones fuertes y el gobierno empieza a carecer de oxígeno, por los límites que se autoimpone como representante de esta burguesía nacional. La burguesía de los Techint, de los Benito Rocca, los Grobocopatel... qué son la burguesía de carne y hueso y que se están llenando los bolsillos con el esquema kirchnerista. Y que con más o menos críticas, cerraron filas con el gobierno. Y por eso tuvo una victoria indisputada. (Pitrola, 2007)

Por su parte, Pablo Rieznik también adscribe a resaltar los elementos de continuidad del nuevo gobierno con los anteriores, en particular con el menemismo y su modelo neoliberal. Al respecto señala:

Los llamados políticos antineoliberales que se pusieron de moda con el duhalde-kirchnerismo han actuado de hecho sobre la base de la irreversibilidad de la tarea desarrollada por el menemismo, con lo cual ya no se trata de las consecuencias del menemismo sino de las consecuencias del antimenemismo, del antineoliberalismo, que con un discurso aparentemente antagónico al de la década del '90 mantiene en lo decisivo políticas que en ese entonces fueron llevadas a extremos muy agudos que todos los argentinos conocemos. (Shinzato y Zanzioth, 2007:49) 
De acuerdo a este dirigente, desde el punto de vista económico el kirchnerismo es la continuidad de un pacto entre el duhaldismo y el FMI mediante el cual se acordó la devaluación/pesificación, la que "salvó a buena parte del capital nacional en quiebra" y que además "fue una mina de oro para los monopolios exportadores" (Shinzato y Zanzioth, 2007:53). La continuidad de este pacto debe observarse para Rieznik, en el pago de 10.000 millones de dólares al FMI. Esto siempre en detrimento y sobre la base de la miseria y el empobrecimiento de los sectores más castigados. Se denuncia la precariedad laboral y los bajos salarios como una constante y una marca de esta gestión.

Respecto a la política de derechos humanos, una de las banderas progresistas del kirchnerismo, Rieznik señala que se trata de una cuestión meramente demagógica y perversa, mediante la cual, a través de un discurso de memoria, se militarizan las escuelas ${ }^{65}$ y se realizan represiones en todo el país. A la vez se critica severamente que los juicios a los responsables del terrorismo de Estado de la última dictadura militar se desarrollan con extrema lentitud (habla de la existencia de sólo dos condenas, las del "Turco" Julián y Etchecolatz) y que a la vez se centran en "elementos relativamente marginales, como si se condenara el exceso".

En definitiva, la gestión kirchnerista es concebida en términos exclusivamente negativos, como una continuidad en términos económicos de los principales ejes del modelo neoliberal, sin ahondar en los ejes que no se continúan. La clase trabajadora es la principal víctima del modelo, en tanto se trata de una salida capitalista, negociada con el FMI y que beneficia principalmente a la burguesía nacional y a los grandes exportadores. Por último, la política de derechos humanos es vista como meramente demagógica y perversa, en tanto se señalan fuertes contradicciones entre, por un lado, los discursos y lo simbólico y, por el otro, las acciones concretas.

\subsection{Corriente Clasista y Combativa (PCR)}

Siguiendo con las lógicas principales que destacábamos más arriba, el kirchnerismo es visto desde la CCC-PCR como un representante del sector imperialista que hegemoniza al bloque dominante. Mientras que en el programa del partido los imperialismos que cumplen este rol son el pro-ruso y el pro europeo, en el caso de Ardura se destaca más el papel de China. En cualquier caso, lo que sigue siendo determinante a la hora de analizar al gobierno nacional de turno, es el imperialismo que está detrás suyo. Como venimos viendo, tal factor resulta tan determinante que termina explicando toda contingencia política local. Hay una

\footnotetext{
${ }^{65}$ El entrevistado hace alusión a conflictos con trabajadores docentes en Santa Cruz y Salta.
} 
identificación directa entre los actores políticos y los intereses de los países imperialistas a los que representan:

Todo el bloque dominante es el blanco de la lucha popular. El gobierno y la política de Kirchner expresan al grupo de monopolios, burguesía intermediaria y terratenientes que hegemonizan el bloque dominante, y por lo tanto, son parte del blanco a golpear con la lucha popular. (PCR, 2004) las negritas son del original

Por su parte, Ardura distingue al kirchnerismo de anteriores gobiernos nacionales justamente a partir de los "socios" que están detrás suyo:

El gobierno de Kirchner es un gobierno de burguesía intermediaria del imperialismo y de terratenientes. Que tiene un frente que está detrás, un frente pesado. No ha cambiado nada sustancialmente de lo que hizo Duhalde, De la Rúa. En todo caso cambian los socios. De La Rúa y Menem trabajaban más para los banqueros y este trabaja más para los terratenientes y el imperialismo chino. Son distintas bandas, distintos sectores económicos y distintas potencias imperialistas. Después él como jefe del bloque tiene que contenerlos a todos. No es que los deja a todos los otros afuera. Pero hay un núcleo diferente al que tenía Duhalde detrás y diferente al que tenía Menem detrás o De La Rúa. Esas son las variables diferentes. (Ardura, 2007)

Sobre la política de derechos humanos del gobierno de Kirchner también hay una visión fuertemente crítica, tildada de demagógica y producto de intereses imperialistas, como la acusación de que la intervención en las FFAA obedece a la presión del imperialismo chino para desplazar a los elementos rusos hegemónicos desde la década del 70 . En la misma línea, primero se lo culpa directamente a Kirchner de la desaparición Jorge Julio López, aunque luego sólo se lo responsabiliza por su no aparición. Al respecto señala Ardura:

R: (...) Esa fuerza que secuestró a Julio López está en la estructura represiva. ¿Pero quien la maneja? Kirchner. Por lo tanto...

$P$ : Sin embargo la desaparición de López puede entenderse como mensaje para frenar los juicios impulsados por Kirchner.

R: Si, si. ¿Pero que hace Kirchner? Nada.

$P$ : ¿Pero porque no quiere o no puede?

R: ¿Cómo no va a poder si es el mandamás de la Argentina? ¿Qué hizo efectivamente para buscarlo? No ha hecho nada. Porque si alguien hubiera querido hacer algo, hubiese ido hacia un Nuremberg.(...) Si todos van a hacer como el de Von Wernich y el de Etchecolatz ¿Cuándo vamos a terminar? En el medio están todos los testigos. Lo vamos a hacer cagar. ¿Y el Estado le va poner a la policía de la provincia a custodiar a los testigos? Si son los mismos que están juzgando. Por lo tanto no tiene ninguna voluntad de ir a fondo. Tiene voluntad de ir en política contra eso para hacer pelota el núcleo que tiene que disputar y hacer pelota a las FFAA. Y para posicionarse de centro-izquierda, frente a centro-derecha. Pues si no hay fascistas, los va a inventar para ese juego político. Que de última las masas, que optan por votar, elijan el mal menor. (Ardura, 2007)

Kirchner aparece como un presidente más entre los diversos "títeres" que han representado los intereses de las potencias imperialistas. Al igual que en la valoración 
que hacían los dirigentes del PO, Kirchner resulta más perjudicial para los intereses del campo popular que muchos de sus antecesores por sus mentiras y su política de cooptación.

\begin{abstract}
Es el presidente más mentiroso... Hemos tenido presidentes mentirosos, como Frondizi y Alfonsín. Pero este, los superó ampliamente. Es el endiabolismo del doble discurso. El tipo te mira a la cara y te dice: "a". Y mirale las manos, y mirale los pies. Porque te dice "a", te mira a los ojos y con esta mano está chorreando acá, con está haciendo otra cosa. Este es Kirchner. Un elemento muy peligroso. A no subestimarlo nunca. Es un cuadro que no se lo puede subestimar, ni a ella tampoco. Los que están atrás son potencias muy poderosas, de enorme inteligencia y experiencia política. (Ardura, 2007)
\end{abstract}

En sintonía con todo esto, el Secretario General del Partido, Otto Vargas, reafirmaba estas consideraciones señaladas tanto en el programa como en los dichos de Ardura. De esta manera le adjudica a Kirchner, como rasgo central la representación de los sectores de la burguesía intermediaria e imperialista. En este sentido enumera una serie grupos económicos cómo los principales socios representados por el gobierno de Kirchner que dominan en diversos sectores de la economía desde el petróleo, la industria y el sector agropecuario. Respecto a la cuestión de la política de derechos humanos la califica como "una vil instrumentación de los sentimientos del pueblo en torno de esta cuestión" a la que lo acusa de obstaculizar la anulación de los indultos a través de sus directivas a los legisladores propios (Shinzato y Zanzioth, 2007:171-172).

Como puede observarse no hay una mirada muy diferente de la que nos daban los dirigentes del PO. En ambos casos se ve a Kirchner $-\mathrm{y}$ al kirchnerismo- como un enemigo claro y concreto, principalmente en tanto representa los intereses de los sectores económicos dominantes. Es visto desde ambas organizaciones como un continuismo de la dominación histórica de determinados sectores, con la novedad de incorporar nuevos aliados, principalmente, el apoyo de distintas potencias económicas.

De la misma manera, su política exterior o de derechos humanos -rescatadas desde ciertos lugares del llamado progresismo- son valoradas negativamente por ambas organizaciones. La política de derechos humanos es tildada de demagógica e insuficiente, mientras que la política exterior -las buenas relaciones con Venezuela, Bolivia, etc.- como resultado de los intereses de los imperialismos que sostienen a cada uno de los gobiernos (esta es la valoración que hace el PCR-CCC, para el PO ni siquiera son valorables aquellos gobiernos).

Es decir, tanto para una como para otra organización, el kirchnerismo es un claro enemigo del campo popular en tanto que representa y sostiene los intereses de los sectores dominantes y hegemónicos del poder económico. Hay una identificación total entre clases económicas dominantes y gobierno nacional. La diferencia que 
podemos señalar en este punto, es el peso que le da la CCC-PCR al imperialismo, a los socios extranjeros que sostienen el gobierno de los Kirchner. Para el PO, Kirchner representa los intereses de las clases capitalistas a nivel general, en tanto no parece significativo distinguir entre el rol que juega una potencia u otra.

\subsection{Movimiento de Unidad Popular (MUP)}

Mientras veíamos que Kirchner es señalado como uno de los enemigos del campo popular para algunas organizaciones, para otras significa el centro de un proyecto político que avanza hacia un modelo nacional-popular. Este es el caso del MUP, que posee una valoración claramente positiva respecto de la figura del ex presidente, en quien ven a un continuador de los principales lineamientos del modelo de desarrollo nacional-popular de tipo peronista.

Kirchner retoma ciertas banderas históricas del peronismo. Enfrenta a nuestros enemigos históricos: al FMI, al ejército, a un sector del grupo concentrado de la economía, se apoya en otros, cosa que nosotros también hacemos en la practica cotidiana; nos apoyamos en unos para poder pelearnos con otros... (Martelli, 2007)

El kirchnerismo, como movimiento político, es visto a su vez como un conjunto de fuerzas, con cuatro patas fundamentales: el PJ, el kirchnerismo puro (en el que se mencionan al Partido para la Victoria y a Compromiso K), los movimiento sociales y el radicalismo $\mathrm{K}$. Esto se relaciona con la necesidad de diferenciar al interior de un movimiento político que ellos consideran fuertemente heterogéneo, lo que a su vez se asocia con su propia necesidad de diferenciarse al interior de un conglomerado político en el que conviven con sectores con los que -según declaran- están lejos de simpatizar.

En el mismo sentido puede observarse una búsqueda constante por explicar algunas de las contradicciones políticas que se le achacan al kirchnerismo, especialmente desde las formaciones políticas de izquierda, vinculadas justamente con la presencia de grupos y personajes asociados a casos de corrupción y antiguos adalides neoliberales. En este sentido, Martelli reconoce la presencia de estos elementos, pero hace hincapié en las complejidades del mundo político que implican negociar, hegemonizar y usar sectores en provecho propio y evitar que sean usados en contra de uno. Algo de esto está presente cuando plantea:

Acá no va a haber un acuerdo entre Díaz Bancalari, Depetri, D’Elía, Solá, Scioli, los que fueran que tengan que ponerse de acuerdo para armar un movimiento político. Este movimiento lo va a armar Kirchner o no lo va a armar nadie. Y Kirchner no lo hace porque sabe que no es el tiempo de abandonar el PJ. No se va a quedar sin el PJ. Con el PJ no se puede hacer nada, y sin el PJ, tampoco. (Martelli, 2007) 
Lo que le interesa resaltar a Martelli es que todo proceso de transformación social orientado desde la política debe despojarse de ciertos reparos y pruritos para no caer en purismos que impidan la construcción del poder político que se necesita para avanzar en los cambios deseados.

Volviendo a la caracterización del kirchnerismo se destaca su papel en términos de política internacional, en especial su rol articulador en la integración regional latinoamericana. Afirma Martelli, que Kirchner posee gran centralidad en dicho proceso en tanto logra constituirse en mediador de las posiciones más distantes política e ideológicamente. De este modo lo señala Martelli:

Me parece que Kirchner es el que se para en el medio de eso. Es el 5.
Es el que se lleva bien con Bachelet, con Lula y con Chávez a la vez. Es
el nexo. Y me parece que eso no es poco importante porque si Kirchner
no estuviera jugando el papel que juega, Bachelet, Tabaré y Lula y
tendrían una distancia muchísimo mayor de Evo, Chávez y Correa de la
que tienen. (Martelli, 2007)

En definitiva, la valoración que el MUP hace del kirchnerismo es claramente positiva en tanto se lo considera como un proyecto político que permite avanzar hacia un modelo de rasgos similares al modelo integracionista desarrollado por el peronismo en sus primeros gobiernos. En esta valoración también está implícito el reconocimiento de las contradicciones y complejidades de todo proceso político, lo que sirve para explicar la convivencia de sujetos políticos e ideológicos claramente heterogéneos entre sí. Del mismo modo se busca ofrecer un lectura del escenario político en el que se destaca la centralidad de sectores y grupos fuertemente reaccionarios y promotores de políticas de corte neoliberal, los que aparecen como la alternativa real y viable al actual gobierno nacional. Dicho de otro modo, organizaciones como el MUP y otras formaciones del campo popular hoy alineadas con el kirchnerismo, ven en el apoyo al gobierno nacional -tanto en la presidencia de N. Kirchner como en la de Cristina Fernández- una forma de frenar el avance de aquellos sectores considerados como una clara amenaza a los avances -más o menos profundos según la valoraciónlogrados en relación a los intereses de los sectores populares.

\subsection{Frente Popular Darío Santillán}

La postura de FPDS es, antes que nada, de oposición al gobierno nacional y al proyecto político que el ex presidente Kirchner encabeza. Dicho esto, es importante aclarar que mantienen diferencias con otras fuerzas también opositoras, en tanto, como veíamos más arriba no esta considerado entre los "enemigos del campo popular", como sí aparece en otros discursos. Veremos algunos detalles de esta caracterización. 
Decíamos que antes que nada el FPDS se considera un opositor al kirchnerismo al que le imputan en primer lugar mantener los lineamientos generales del modelo económico neoliberal (definen al modelo económico kirchnerista como "un modelo donde es dominante la explotación capitalista de recursos naturales y humanos con un perfil exportador" (FPDS, 2007)).

Desde el punto de vista político, la principal crítica que señalaba Obregón es que el kirchnerismo construye su andamiaje político apoyado en las viejas y corrompidas estructuras del PJ, con sus gobernadores y caudillos, además de la burocracia sindical, todo lo cual "no hace más que reafirmar la tendencia antipopular de este proceso". (Obregón, 2006)

Del mismo modo se destacan los antecedentes del ex presidente Kirchner como fuertemente vinculado al peronismo de los '90s, lo que a su vez sirve para argumentar el carácter demagógico de su discurso, tanto en términos de cuestiones socioeconómicas como en el tema de derechos humanos. Respecto a este punto se rescata tibiamente su accionar en torno a la recuperación de la memoria y el juzgamiento de los responsables del terrorismo de estado de la última dictadura militar, pero se destaca la contradicción con los derechos humanos de hoy, por la profundización de la concentración y la desigualdad social. Las virtudes que pudieran destacarse son explicadas por la coyuntura de la que deriva su gobierno, "resultado y consecuencia de la crisis del 2001".

Entre las concesiones que se le hace al kirchnerismo esta la valoración sobre su política exterior, pero también es explicada en el marco de la coyuntura política, y también por la intencionalidad de sus aliados (en particular Chávez) más que por la intencionalidad del kirchnerismo: "desde la lógica del gobierno venezolano nos parece correcto" (Obregón, 2006). En este punto encontramos algunas diferencias con otras posiciones opositoras que identifican al kirchnerismo como representante directo de los intereses de la clase dominante y los imperialismos, en tanto se señala que "en política no hay lugares vacíos" y que en tal sentido es preferible el perfil de política exterior del kirchnerismo al que pudieran tener otros posibles gobiernos. Esto le preguntábamos y esto nos respondía Obregón:

$P$ : ¿Considerás que el hecho de que Kirchner esté en el gobierno es positivo, negativo o indistinto para el contexto regional?

$R$ : Positivo porque la alternativa que visualizamos es una alternativa por derecha. Nosotros no vamos a llamar a votar Kirchner. En política no hay lugares vacíos. Si no estuviera Kirchner, seguramente habría un candidato de la derecha. (Obregón, 2006)

Otra diferencia con otros discursos opositores aparece cuando lo consultábamos a Obregón sobre la desaparición de Jorge Julio López. De algún modo 
se parte de un lugar diferente al de otros discursos, en el cual el Estado no es omnipotente ni el gobierno tiene total control sobre los elementos del Estado. Así, se parte de identificar a los responsables como sectores de derecha que buscan entorpecer las políticas de derechos humanos que incentiva el gobierno, pero también se le exige mayor diligencia y efectividad en su búsqueda.

A partir de lo de López, quizás ya se veía desde antes, hay un reposicionamiento de los sectores de ultra derecha, que siempre tuvieron niveles de actividad y me parece que la respuesta tiene que ser la movilización popular. Y sí me parece que hay que exigirle al gobierno un poco lo que se está planteando y exigiendo ahora, que ponga todos los recursos en función de la investigación y que de a conocer: qué se investigó, en qué estado está la causa. Hay como un hermetismo que a veces parece que lo que el gobierno quiere es que el tema salga de la agenda. (Obregón, 2006)

De todos modos hay un reconocimiento del poder de los responsables del secuestro, como así también de las limitaciones de los recursos que controla el gobierno.

Es evidente que tienen mucho poder porque hacer desaparecer a alguien y que después de 2 meses no se sepa nada, con la cantidad de. recursos que movió el gobierno. Es un tema grave. (Obregón, 2006)

\subsection{MPR-Quebracho}

La valoración respecto al kirchnerismo es claramente negativa, sin casi matices. Constituye, como veíamos más arriba uno de los gerenciadores de los sectores dominantes. Aparece definido como un claro exponente de la Entrega, de la recomposición de los lazos de dominación, como así también de la cooptación de organizaciones del campo popular.

Para nosotros Kirchner es un tipo que hizo la política de entrega y saqueo. Básicamente fue eso. Y en cuanto a los lazos de dominación interna, viene a recomponerlos, a intentar domesticar la insurgencia popular que había en las calles, que en un sentido lo logró. Con cooptación, con quiebres..., con guita. (Esteche, 2007)

En otro lugar es definido, de modo similar de la siguiente manera:

Para nosotros el gobierno de Kirchner representa el intento más serio de recomposición política de las clases oligárquicas, representa a los sectores más lúcidos del régimen (...) Es cambiar algo para que no cambie nada. (...) (Rubio y Del Grosso, 2005:30)

Entre las cuestiones puntuales que pudimos recoger, Kirchner es atacado desde sus antecedentes como parte "del desguase, la quiebra y la venta de YPF", de pagarle a Daer "para que se lleve los minerales de la Argentina", de haber posibilitado la instalación de Monsanto y Cargill, de haber violado la Ley de Tierras en su propio beneficio, de "enajenar la costa", en fin de "vender todo". En la misma línea también se lo señala como "el presidente que tuvo más presos políticos en la Argentina, del 82 
para acá" y también como "el presidente que más manifestaciones apaleó de todos los presidentes" 66 (Esteche, 2007). Como se ve, se le adjudican variadas y múltiples responsabilidades de toda índole y naturaleza, a la vez que se trasluce una concepción del poder político (Estado y gobierno, en este caso) como cuasi omnipotente, similar a lo que veíamos en otras organizaciones. ${ }^{67}$

En relación a esto es interesante observar que aquellos puntos que podrían ser valorados desde la orientación político ideológica de la organización -política latinoamericana, distanciamiento del FMI, juicios a los responsables del terrorismo estatal, etc.- no son vistos como responsabilidad ni, por tanto, como méritos de la gestión, sino resultados de cuestiones estructurales, procesos históricos o méritos de otros (es el caso de la política exterior latinoamericana). ${ }^{68}$ Es decir notamos una cierta variación ad hoc de la aplicación de perspectivas de análisis objetivistas y subjetivistas en función de la valoración que se le quiera dar a las acciones del kirchnerismo: lo bueno es producto de lo estructural, de cuestiones objetivas ajenas a las decisiones individuales y lo malo resultado de acciones (mal) intencionadas de los actores.

Otra cuestión que se destaca con bastante centralidad es el tipo de construcción política del kirchnerismo -lo que le establece una suerte de límites estructurales- ya que "nace de un acuerdo político, que pacta con el aparato, que define una forma de hacer política que es con el aparato, con la mafia." (Esteche, 2007). Este pecado original constituye uno de los rasgos más señalados. Es claro el contraste con el planteo que hacía el MUP, que señalaba que la relación con aquellos sectores non sanctos se presentaba ineludible. Allí, la variación ad hoc objetivismo/subjetivismo funciona en el sentido valorativo inverso: la malo es estructural, lo bueno intencional. El equilibrio en el uso variable de diferentes perspectivas de análisis -en este caso, objetivistas y subjetivistas- sin dudas se ve fuertemente atravesado los modelos ideológicos (Van Dijk, 2008) que portan los sujetos.

\footnotetext{
${ }^{66}$ Es ilustrativo de la valoración que se tiene del kirchnerismo la caracterización de la política de derechos humanos del gobierno: "La política de derechos humanos de Kirchner es tener presos políticos, es perseguir a los que luchan, es fusilar a los docentes, es sacar a la gente de la calle y cortar con el derecho de protesta del pueblo" Shinzato-Zanzioth, 2007: Esteche, p.192.

${ }^{67}$ Hay frases ilustrativas sobre esto como: "los diarios no le imponen a Kirchner lo que tiene que decir, Kirchner le impone a los diarios lo que tienen que decir, con la pauta oficial. A Clarín y La Nación los tiene comprados. Además es el mismo grupo..." Esteche, 2007.

68 - "[el acercamiento con Chávez] No es una virtud de Kirchner, es una virtud de Chávez." (Esteche, 2007)

- "Kirchner no tenía manera de no identificar al FMI como enemigo, porque eso ya estaba en la cultura política, en los valores políticos de los argentinos. No tenía manera de no juzgar a los milicos, porque la impunidad estaba ya vapuleada como parte de la cultura política de los argentinos." (Esteche, 2007) - "Que hoy estén juzgando Von Wernich o que Etchecolatz esté preso no es porque Kirchner gobierna, sino porque el pueblo luchó para eso. (...) Kirchner no tuvo otro remedio que atender mínimamente los reclamos históricos del pueblo." (Shinzato-Zanzioth, 2007: 192).
} 
En resumen, y volviendo a la caracterización del kirchnerismo, la valoración es excluyentemente negativa, sin ningún tipo de concesión, concebido como representante o gerenciador de los capitales imperialistas: "el kirchnerismo vino como gerenciador del capital europeo pero hoy es gerenciador del capital yanqui" (Shinzato y Zanzioth, 2007:190). Aparece así, como en otros discursos ya analizados, una identificación plena entre los grandes capitales y sus gerentes políticos, en la se estrechan los espacios de autonomía e indeterminación que pudieran haber en la dimensión de lo político.

\subsection{MTD - Aníbal Verón}

Por contraste con el resto de los discursos, la caracterización respecto del kirchnerismo que hace Daffunchio es bastante original y llamativa, a la vez que nuevamente nos recuerda las dificultades de extrapolar el discurso de este dirigente al resto de la organización cuando se trata de un tema tan controversial. Lo que parece interesante para observar es que se trata de una visión que no resulta de una postura previa concluyente, de un tipo de cierre o clausura, que ordena las dimensiones a evaluar a partir de principios determinantes. Dicho de otra manera, lo que hemos visto en discursos anteriores, especialmente en torno a esta cuestión, son posturas a favor o en contra que no suelen marcar bemoles y que a la vez suelen utilizar ciertas operaciones lógicas -adecuación de enfoques objetivistas o subjetivistas- para sostener un posicionamiento determinado.

Para Daffunchio el gobierno de Kirchner aparece en primer lugar marcando una discontinuidad, un quiebre, es catalogado como "un gobierno muy distinto a los gobiernos anteriores". En este sentido se destaca que "en muchos aspectos ha sido más positivo que los anteriores", como por ejemplo en lo que refiere a la posición internacional y a la política en relación a la última dictadura militar. Es decir, se destacan cuestiones positivas sin que por ello se caiga en una valoración positiva en términos generales. Entre otros puntos positivos se reconoce su audacia e iniciativa, el respeto a determinados principios y el avance sobre estructuras $u$ opciones políticas menos deseables. Es bastante ilustrativo de lo que venimos diciendo la siguiente cita, en el contexto de los resultados de las elecciones de octubre de 2007:

Por un lado hay más de lo mismo, pero por otro lado no. En otro lado se lo volteó a Manolo Quindimil, a Villordo, en Echeverría... a Bropi, a Alak. y lo hizo Kirchner. Entonces ahí hay nueva política. Vamos a ver que pasa con esa nueva política. Hasta donde llega. El Barba Gutiérrez... no es un revolucionario, pero no es un facho. Entonces, desde esa óptica decís, upa, que carajo va a pasar acá. Desmembró al duhaldismo, terminó de desmembrar al menemismo. Las otras opciones que hay... Lilita Carrió, López Murphy... Por suerte desaparecieron. En esta 
elección López Murphy, Blumberg... Sobisch, me encanta, fascinado estoy. (Daffunchio, 2007)

De este modo aparece una evaluación que incluye una mirada -ausente en otros análisis- que incorpora a las otras opciones políticas con posibilidades reales de fortalecerse desde lo electoral. De este modo se destacan elementos positivos y se abre un punto de expectativa hacia lo que podía pasar con la asunción de Cristina Fernández.

Pero, como decíamos más arriba, el reconocimiento de algunos elementos positivos no lo imposibilita para descargar toda una serie de críticas sustanciales. Entre ellas se menciona fundamentalmente la ausencia de una redistribución de la riqueza imprescindible y urgente. Así lo plantea Daffunchio:

Todo esto hay que analizarlo con una visión nueva y con más profundidad. Si me decís si lo de Kirchner fue positivo o negativo, fue positivo en algunas cosas y negativo en otras. $Y$ en términos de redistribución del ingreso, se cagó; se cagó en reivindicaciones históricas de nuestro sector; si uno computa el aumento de precios con el aumento de salarios, los niveles de pobreza se mantienen, ni que hablar los niveles de indigencia. (...) El gran problema de la Argentina sigue siendo la redistribución del ingreso. (Daffunchio, 2007)

En el mismo orden se critica la política de recursos energéticos, la política agropecuaria -la "sojización"-, el pago de las deudas a los organismos multilaterales y el modo en que se encaró el caso López, privilegiando cuestiones particulares, partidarias, sobre los intereses generales, democráticos. En relación a esto último, hay una crítica general al modo de hacer política, a su carácter avasallante, de imposición, que promueve escenarios políticos de amigo/enemigo que no concibe puntos intermedios. Esta última crítica resulta interesante porque plantea que de haber tenido Kirchner otra postura respecto a algunas organizaciones -la CTA, el propio MTD-AVse podrían haber tejido algunas relaciones, no de apoyo absoluto, pero si de menor confrontación y apoyo en cuestiones específicas.

Defecto que tiene, el mismo defecto que lamentablemente le pega la derecha, le pega todo el mundo: la forma de hacer política que tiene. Una forma muy maltratadora, muy desconfiada, que se yo... El proceso que hicieron con De Gennaro, que se yo... Yo escuché que decía, "De Gennaro se perdió ser el Lula argentino". Pero escuchame, lo que le hicieron a De Gennaro... De Gennaro se peleó con los monos de la CGT cuando la CGT hacía temblar al país. Partió la CGT, le disputó un sindicato a la CGT!! (...)Y viene Kirchner y le dice sumate a la CGT, yo te apoyo, después vas a ser Lula. Pero tomatela, dame la personería jurídica. Le daban la personería jurídica, yo te puedo asegurar que De Gennaro hubiese sido uno de los principales cuadros en lo gremial y en lo político de Kirchner. Ahora la personería jurídica no se la dio y quebró. (...) ¿Con nosotros que hizo? Entregate. Entregá tus reivindicaciones, entregá el puente, entregá a Kosteki y Santillán... y después vas a andar bien con nosotros. Andá a la puta que te parió. Peleamos. Perdimos, pero peleamos. Entonces, desde esa óptica, ha generado muchos 
heridos también. Por derecha, por izquierda, por todos lados.

(Daffunchio, 2007)

Nos permitimos citar este extenso fragmento porque nos parece que ilustra cabalmente este posicionamiento respecto al kirchnerismo que resulta interesante, al menos novedoso respecto a los que veníamos observando. Nos referimos a que hay una valoración compleja, que sin dejar de ser crítica, es capaz de rescatar algunos elementos y contextualizar su diagnóstico en un escenario político en el que otros discursos no lo hacen, salvo aquellas organizaciones francamente oficialistas. La posibilidad de reconocer virtudes sin perder la capacidad crítica, cuestión que así planteada no parecería ser algo exótico, sí lo parece en relación a otros discursos. Creemos que se hace evidente el modo en que opera el tipo de cierre o clausura que se intenta como explicación de lo social, estableciendo más o menos margen de maniobra en el análisis de la realidad concreta, generando mayores o menores niveles de determinación o sobredeterminación.

\subsection{Movimiento Teresa Rodríguez}

El kirchnerismo aparece caracterizado, al igual que en otros discursos que venimos viendo, como una continuidad de los gobiernos anteriores, desde Alfonsín en adelante, incluyendo el de Menem y el de De La Rúa. Desde esta perspectiva, los cambios que son observados en algunos aspectos (política internacional, derechos humanos, transversalidad) son producto de las circunstancias, del estado de la opinión pública, de la crisis del 2001, etc. Así lo decía Martino:

\section{P: Cómo evaluás la gestión Kirchner? \\ R: Kirchner ha sido producto de la rebelión y es la fracción de la burguesía que mejor supo entender la rebelión. Es el sector de la burguesía que supo interpretar que para desmontar la rebelión y para recuperar la institucionalidad había que expropiar las banderas que había levantado la rebelión. Por eso es que Kirchner cuando asume lo hace con el $20 \%$ de los votos, y la única manera que tenía de ganar consenso era planteando las banderas de la rebelión. ¿Cuáles eran las banderas de la rebelión? Los derechos humanos. La trasversalidad: el fuerte cuestionamiento a los partidos existentes. Kirchner, con la promesa de la transversalidad viene a plantear que venía a liquidar lo viejo y a construir lo nuevo. (Martino, 2007)}

De este modo vuelve a aparecer la misma operación lógica según la cual lo que podría ser visto como positivo es un resultado de elementos externos, objetivos, que se imponen sobre las voluntades e intencionalidades de los actores. Paralelamente, lo negativo no es resultado de factores externos y objetivos, sino de la decisión e intención de los actores en cuestión.

Entre las definiciones que nos daba Martino, destacaba que "tampoco ha variado en términos represivos, sino que ha variado de acuerdo a las circunstancias". 
Sobre el tema de derechos humanos sostenía que "lo acotó a la memoria. En cuanto a la memoria cumplió un papel positivo", pero "al mismo tiempo judicialaza y criminaliza el reclamo social" y "le permite eludir que los derechos humanos son mucho más que eso y que tiene que ver con la vida cotidiana de millones de tipos." Del mismo modo se señala la "complicidad del Estado y del gobierno" en el secuestro y desaparición de Jorge julio López, ya que "nadie puede decir que no se sabe, que no se puede hacer una investigación". Sobre la cuestión de la trasversalidad señala que "basta ver como están compuestas las listas para las próximas elecciones y la trasversalidad se fue a la mierda." Esto a la vez se explica porque "necesita un PJ fuerte y unido para etapa que viene". (Martino, 2007)

De este modo la valoración de la gestión kirchnerista aparece atravesada por la "obligación de las circunstancias" y por la demagogia, la intencionalidad oculta en cada acción. En esta línea, respecto a la política internacional señala que "tomó las banderas del antiimperialismo, la alineación con Cuba, con Chávez, pero porque necesitaba justamente cooptar al movimiento." De igual modo afirma que "Levantó las banderas del capitalismo en serio. Pero son fuegos de artificio. La desigualdad en la distribución de la riqueza se ha seguido acrecentando." Por todo esto concluye que la principal "virtud" de Kirchner es que "ha sabido tener un doble discurso que ha logrado engañar". (Martino, 2007)

Es decir, en líneas generales el kirchnerismo es visto como una fracción de la burguesía, lo que ya lo determina como un enemigo del campo popular y como parte de los sectores dominantes. Esto trae consigo una fuerte crítica hacia los sectores que se han acercado al kirchnerismo y sus obvias consecuencias respecto a la vinculación con otras fuerzas del campo popular. Esto se ilustra con definiciones como la que aparece en la publicación Todo o nada, cuando en relación a los actos de conmemoración del golpe de Estado del 24 de marzo del 76 señalaban que:

\footnotetext{
"este 24 mostró la decisión de las clases dominantes de avanzar también en la institucionalización de los DDHH. Para eso cuenta con una opinión pública no acabadamente comprometida, con un movimiento social adicto y con algunos organismos de $D D H H$, por lo menos, confundidos" (Todo o Nada, 2006:6)
}

Donde se ve una equivalencia entre el gobierno y las clases dominantes, a la vez que se critica fuertemente los distintos apoyos con los que el gobierno cuenta.

\subsection{Barrios de Pie (Libres del Sur)}

En la valoración respecto del kirchnerismo que realiza Baigorria y que se respalda con otros escritos de la organización, encontramos un posicionamiento político, que desde su discurso, se presenta dejando un considerable espacio a lo 
contingente, estableciendo un tipo de sutura parcial en su concepción de lo social. En este sentido, resulta muy similar a lo que veíamos en Daffunchio, aunque en este caso se trate de una organización que integra las filas del oficialismo. Con todo esto que venimos diciendo queremos destacar que se trata de un posicionamiento político que no propone un cierre definitivo y que resalta los aspectos contradictorios y contingentes que atraviesan el universo de lo social en general y el de lo político en particular.

Como sabemos, al momento de realizar esta entrevista -25/09/07-, Libres del Sur mantiene una valoración positiva del kirchnerismo, que en la actualidad ha variado. Kirchner es definido como el "presidente que con audacia y superando significativos obstáculos, va orientando la nave patria hacia un nuevo Proyecto Nacional, de desarrollo justo y soberano" (LS, 2008). Una cuestión que aparece como fundamental es el modelo económico que privilegia el crecimiento del empleo y, simultáneamente, la promoción del mercado interno. Estos elementos, junto con la ausencia de una "política de garrote" frente al conflicto social, aparecen como los puntos de ruptura con el gobierno anterior: "[Duhalde] Planteaba una economía de exportación, por eso devaluó, pero con control social fuerte, sin mercado interno. Que es el plus, sumamente significativo que le aporta Kirchner. Que es lo que para nosotros le cambia el carácter a una cosa o a la otra" (Baigorria, 2007).

De esta manera se destaca lo que se entiende como puntos de ruptura o discontinuidad tanto con el modelo que primó en los '90s como con su inmediato antecesor en la presidencia. Además de políticas mercado internistas en lo económico aparecen con fuerza rasgos vinculados a la política exterior, los derechos humanos, etc. Sobre lo primero, destaca que: "La política internacional de Kirchner ha sido absolutamente importante: en la consolidación y ampliación del MERCOSUR, en bancarlo a Chávez, lo de Kirchner a sido clave en el nivel sudamericano. Lo de Kirchner ha sido muy claro en ese aspecto, bien nítido." (Baigorria, 2007).

Además del reconocimiento de toda una serie de puntos positivos, no se desconocen falencias o errores, ni se cae en un posicionamiento definitivo. La crítica más importante remite a cuestiones básicamente políticas, a los apoyos y aliados que va definiendo el gobierno en su construcción política. De aquí aparece la demanda ("que venimos reclamando con más fuerza") de renovación política, de formar nuevos cuadros que permitan una construcción que pueda prescindir de algunos elementos sobre los que en la actualidad se apoya su construcción política.

El más urgente de todos [los pasos a seguir] es favorecer la emergencia de una dirigencia nueva y comprometida con el proyecto nacional. Esa es la asignatura pendiente. Porque eso es lo que pone en riesgo al conjunto. Vos podés criticar una parte de la política internacional, una 
parte de la económica, más allá, más acá. Pero los que vemos que este es un proyecto diferente vemos el riesgo: si yo me apoyo en las burocracias políticas desprestigiadas, termino pareciéndome más esas burocracias, termino más pegado a lo viejo que a lo nuevo. (...) Que no quiere decir pasar la azada y barrer con todo. Porque tampoco vos podés dejar que todo eso se te vaya para el otro lado. Pero tampoco podés ahogar esto. La izquierda de Kirchner no puede llegar a este proceso amordazada. (Baigorria, 2007).

De este modo el posicionamiento de la organización se ajusta a las contingencias políticas y no establece una identificación plena, cerrada con el kirchnerismo. Esto aparece con más nitidez cuando el entrevistado se explaya sobre la posibilidades de que se desarrolle la conformación de un espacio "nacional-popular" a partir de ciertas convocatorias que se hacen desde diversos espacios, uno de ellos es el de la Paritaria Social convocado desde la CTA. Así lo planteaba Baigorria:

[En la] Paritaria Social que está planteando la CTA, me parece que por diversas especulaciones confluye un campo importante. (...) Hay que ver qué grado de vinculación o de influencia puede tener esto, para que emerja una expresión política del campo popular de cierto peso, envergadura, poder de fuego en lo electoral... (...) Con respecto al gobierno de Kirchner, me parece que eso va ser más adentro o más afuera del gobierno de $K$, acorde a las circunstancias, acorde al gobierno que plantee Cristina después del 10 de diciembre. (...) De acuerdo al rol que podamos jugar, digamos, el andarivel de izquierda del kirchnerismo. (...) Yo creo que lo tajante no va a estar tanto en el adentro o en el afuera. Yo tengo una idea de que vamos para una cosa distinta. El espacio nacional y popular va a tener por dentro del kirchnerismo o como aliado del kirchnerismo, con el gobierno nacional, va a haber condiciones para que se geste una representación política más autónoma. Que no es necesariamente antagónica, con el gobierno nacional. (Baigorria, 2007).

Es decir, no sólo se deslizan críticas importantes al gobierno del cual forman parte, sino que se piensa en términos políticos más allá de las circunstancias específicas y concretas del momento, abriendo la posibilidad de nuevos alineamientos que no necesariamente se condicen con el "adentro-afuera" respecto al gobierno. Depende de lo que se pueda ir conformando, del peso que pueda llegar a adquirir el "andarivel izquierdo" dentro del armado oficial y de los pasos efectivos que dé la gestión de Cristina Fernández en su gestión como presidenta. ${ }^{69}$

\subsection{Continuismo, complejidades de lo social y perspectivas ad hoc}

Como señalamos al principio de este apartado, el posicionamiento en la coyuntura política concreta define los acercamientos y alejamientos políticos de las distintas organizaciones. Como sabemos, desde la asunción de Kirchner se produjo un

\footnotetext{
${ }^{69}$ Hoy sabemos finalmente que las diferencias planteadas no fueron zanjadas, lo que derivó en el alejamiento de la organización de la órbita oficialista.
} 
fuerte reacomodamiento de las distintas fuerzas a partir de la valoración y el posicionamiento al respecto.

La distinción más evidente es la de las organizaciones que apoyan al kirchnerismo y las que no; es decir el MUP y MBP-LS ${ }^{70}$ y el resto. Ahora bien, además de esta distinción podemos pensar otras superpuestas, como aquella que diferencia a las organizaciones que ven una total continuidad de Kirchner respecto a las presidencias anteriores. Desde este criterio, vuelve a ser útil la distinción entre las organizaciones que se declaran marxistas-leninistas y las que no.

En efecto las cuatro organizaciones que se declaran marxistas-leninistas señalan que la presidencia de Kirchner constituye una clara continuidad de las presidencias anteriores desde la vuelta de la democracia. En rigor, no existen para estas organizaciones puntos de ruptura relevantes en los sucesivos gobiernos de Alfonsín a la fecha. Se trata de la continuidad de la dominación de los mismos sectores socioeconómicos, sigue siendo la burguesía, los grandes grupos económicos los que en realidad gobiernan.

Esta postura es planteada apelando al modelo dicotómico marxista trabajocapital el que, en su aplicación al análisis de la realidad socio-política, deviene en una perspectiva binaria que pareciera reducir el espacio para las posibles diferenciaciones al interior de la contradicción fundamental. De este modo, el tipo de cierre que se hace para aprehender y explicar el universo social termina desestimando las contradicciones y graduaciones que pudieran haber al interior del ámbito político, en tanto en última instancia remiten a los intereses de algunas de las dos clases fundamentales.

Sin embargo esta posición, lejos de facilitar las posibilidades de articulación política a partir de la constitución de dos grandes bandos que representen a las dos grandes clases, pareciera reducir las probabilidades de articulación, específicamente las de las fuerzas que pretenden la representación de la clase trabajadora. Entendemos que esto se debe a la especificidad de la dimensión política que dista de reproducir o reflejar el supuesto esquema dicotómico que, en lo esencial, pretende agotar la explicación de lo social. En otras palabras, consideramos que muchas de las dificultades que las organizaciones del campo popular muestran en sus posibilidades de articulación política pueden deberse a lo que observamos como una persistente negación de la especificidad y autonomía -que por supuesto nunca es absoluta- de lo político.

La ausencia de graduaciones no sólo se observa en la caracterización de los actores del escenario político, si no también en la concepción del cambio: las mejoras

\footnotetext{
${ }^{70}$ Con la aclaración ya realizada en la nota anterior.
} 
que puedan observarse en algunas dimensiones, variables o indicadores suelen ser desestimadas en tanto se subsumen a una lógica general que las absorbe y las desactiva. Del mismo modo, también se observan planteos y posicionamientos que parecieran desatender la multiplicidad de niveles, actores, posturas, tensiones y contradicciones presentes en toda gestión gubernamental. Tanto las organizaciones que se presentan cercanas al oficialismo como el FPDS y el MTD-AV hacen alguna mención sobre la importancia de tenerlas presente.

Finalmente llegamos a un mecanismo habitual que suele utilizarse que llamamos aquí la aplicación de perspectivas ad hoc. La dialéctica entre individuo y sociedad, el modo en que interactúan e inciden uno en el otro atraviesa todo el pensamiento sociológico y deriva en dos grandes posturas, la subjetivista -cuando se hace hincapié en el peso del individuo, en su autonomía y en su capacidad para incidir y modificar la estructura social- y la objetivista -que destaca el peso de las estructuras sociales sobre las individualidades. ${ }^{71}$

Nos parecía interesante detenernos en señalar los distintos usos que se hacían de ambas perspectivas, apelando a una u otra en función de la carga valorativa deseada en el análisis de determinado actor político, en este caso, la gestión del ex presidente Kirchner. Podemos diferenciar según este criterio entre las organizaciones que hacen un uso ad hoc de los diversos enfoques y las que no. Nos parece que tanto el MTD-AV, el FPDS como MBP-LS se posicionan desde un lugar que les permite reconocer virtudes y defectos del kirchnerismo sin apelar a cambios de perspectivas en función de la valoración que se busca. Por el contrario, en el resto, ya sean opositoras u oficialistas, se pasa de un enfoque subjetivista a uno objetivista para acentuar defectos o virtudes: todo lo bueno es producto de las circunstancias (lo social, objetivo, estructural) y lo malo producto de la acción intencionada del individuo en cuestión. O viceversa.

Entendemos que todo análisis y valoración sobre un tópico como este, toma posición en relación al peso que debe adjudicársele a lo estructural/objetivo y a lo individual/subjetivo. En la búsqueda del equilibrio entre los dos extremos, surge un amplio abanico de posibilidades. Lo que observamos es que la rigidez de algunas posiciones hace necesario el uso ad hoc de alguna de estas perspectivas. Esto no sucede cuando los posicionamientos políticos adoptan formas más flexibles, los que no se ven amenazados por reconocer las virtudes o defectos de lo que se esté evaluando. La utilización de perspectivas ad hoc pareciera entonces estar asociada a la rigidez con la que se presentan los principales rasgos identitarios, como un

\footnotetext{
${ }^{71}$ Para una profundización de este tema ver Alexander, Jeffrey C. ([1987]1989), Las teorías sociológicas desde la Segunda Guerra Mundial, Barcelona, Editorial Gedisa.
} 
indicador o síntoma de los espacios que se abren para las operaciones políticas de articulación. 


\section{CARACTERIZACIÓN DEL ESCENARIO LATINOAMERICANO}

Un tema de discusión y un punto de debate interesante para cotejar cercanías y distanciamientos entre las posturas de las distintas formaciones políticas lo constituye la valoración respecto al escenario latinoamericano. Consideramos que posee una importante centralidad, especialmente a partir de los procesos políticos de izquierda o centro izquierda que se han venido desarrollando en países como Venezuela, Bolivia, Ecuador, Nicaragua, Brasil y Uruguay.

La valoración respecto a cada una de estas experiencias permite definir y distinguir puntos de encuentro y desencuentro interesantes para pensar en posibles niveles de consenso y acuerdo o en la imposibilidad de los mismos.

\subsection{Polo Obrero (Partido Obrero)}

Respecto a la realidad latinoamericana, la mirada es fuertemente escéptica y crítica en relación a los diferentes procesos políticos del espectro de la izquierda y centro izquierda. En primer término se establece una separación entre las experiencias de Chávez y Evo Morales y las de Brasil, Uruguay y Argentina. Los gobiernos de estos últimos países son acusados por Rieznik de haberse empeñado en "derrotar y desmoralizar a las clases obreras de sus propios países para subir como alternativas, en definitiva, neoliberales" (Shinzato y Zanzioth, 2007:56). En la misma línea se manifestaba Pitrola, aunque todavía va más allá, cuando consideraba a los procesos de Uruguay y Brasil como "eje de la política de dominación norteamericana en América Latina”. (Pitrola, 2007)

Por su parte, los casos de Bolivia y de Venezuela son considerados de manera diferenciada, pero no exentos de fuertes críticas. Ambos representan proyectos esencialmente nacionalistas, y encuentran allí sus límites constitutivos. Un síntoma de esos límites, es justamente la vinculación de ambos gobiernos con los mencionados en primer término:

"La política que están desarrollando Evo Morales y Chávez tiene límites terriblemente grandes como se demuestra en el hecho de que Chávez se empeña en defender como socios a estas catástrofes políticas del Cono Sur" (Shinzato y Zanzioth, 2007:57)

A Chávez, a la vez se le achaca el hecho de querer construir el Partido Socialista Unificado de Venezuela (PSUV) "echando a la izquierda y regimentando estatalmente el movimiento de los trabajadores". Por último, Rieznik destaca que las nacionalizaciones que viene llevando el gobierno venezolano son de "naturaleza extremadamente precaria y restringida" en tanto constituyen "nacionalizaciones clásicas burguesas, con reparación económica e inclusive celebrada por los “nacionalizados"”' (Shinzato y Zanzioth, 2007:57). 
Pitrola, por su parte, coincide en catalogar ambos procesos como "experiencias nacionalistas". Respecto al caso venezolano, y en consonancia con lo planteado por Rieznik, agrega fuertes críticas respecto a las intenciones de Chávez de reforzar su poder personal, en desmedro de los sectores populares, la clase trabajadora y la izquierda de ese país:

El propio Chávez se lanza a reforzar el propio régimen de construcción personal en desmedro de una clase obrera que está luchando y que en muchos planos es reprimida y perseguida por el propio gobierno de Chávez, justamente en el momento en el que ha constituido el partido único. (...)

El chavismo en vez de apuntar contra el imperialismo está apuntando contra los sectores del movimiento popular que luchan de manera independiente. (Pitrola, 2007)

En relación al caso boliviano, las críticas corren por caminos similares. Se critican fuertemente las intenciones del gobierno de "pactar" y "acordar" con la burguesía cruceña, con "la rosca" y con las petroleras. Se lo concibe dentro de los mismos marcos y limitaciones que el caso venezolano, es decir, como un nacionalismo que no rompe ni se enfrenta con los grandes poderes económicos y políticos de la sociedad.

En este contexto señala que América Latina vive un proceso de fuerte convulsión social y movilización de masas que puede reconducir estos procesos políticos actuales hacia un camino verdaderamente revolucionario. Es decir, para Pitrola, en cada uno de estos países aparece la posibilidad de "correr por izquierda", de superar las fuertes y claras limitaciones de las actuales dirigencias. A eso apuesta su organización.

Es decir el período histórico de América Latina es de convulsión y de un proceso de lucha por la autonomía nacional y de irrupción de masas. En este cuadro político, el Partido Obrero se planta, desde el punto de vista de una salida obrera y campesina. También como herramienta de unidad de América Latina. Estos gobiernos nacionalistas y centroizquierdistas no están uniendo a América Latina y menos que menos a los explotados de América Latina. Están cada uno estableciendo un nuevo escalón de asociación con el imperialismo. Lo de Tabaré y lo Lula. (Pitrola, 2007)

\subsection{Corriente Clasista y Combativa (PCR)}

En su diagnóstico sobre el proceso latinoamericano se rescatan algunos procesos políticos latinoamericanos, en particular los casos de Venezuela y Bolivia, sobre los que la organización tiene miradas positivas aunque con reservas y críticas. En general se destaca el apoyo popular de ambos procesos y la dirección general que han tomado, aunque en tanto se separan del modelo de estrategia política que ellos sostienen, preludian un escenario de fuerte conflictividad que se acercaría más al modelo de revolución clásico al que ellos adhieren. En este sentido señala Vargas: 
"Nosotros no creemos que sea posible desde el gobierno ir a la destrucción del poder pero estamos atentos a lo que sucede porque Chávez dijo "El movimiento bolivariano es un movimiento pacífico pero no desarmado"',

Y luego:

"En cuanto a lo de Morales valoramos mucho el proceso de auge revolucionario que se da en Bolivia desde la lucha por el agua en Cochabamba. (...) Y a Evo lo vemos como resultado de ese proceso, un proceso contradictorio porque hay sectores en el gobierno que tienen posiciones muy reformistas. También en Bolivia es casi inexorable que se vaya a un enfrentamiento." (Shinzato y Zanzioth, 2007:174)

En la misma línea, Ardura reafirma el apoyo explícito y necesario a ambos proceso políticos, pero pone reparos en algunas de sus características. En este sentido hace una comparación entre Chávez y Perón, destacando sus puntos comunes, a los que critica:

Es lo mismo que proponía Perón. ¿Qué nos proponía Perón? Yo le disputo por dentro. Chávez está proponiendo lo mismo, aunque un poco más duro. Vamos a ver ahora. Yo lo quiero al comandante. Y lo voy a apoyar y me voy a jugar por él, pero ese socialismo siglo XXI de Dieterich es una señal del estado burgués, del estado oligárquico. (Ardura, 2007)

En pocas palabras podemos decir que la caracterización del panorama político internacional se centra en constatar la crisis por la que estaría atravesando la principal potencia imperialista. Al mismo tiempo se destaca el avance de algunos procesos políticos latinoamericanos, estableciendo una clara separación entre los casos "genuinamente populares" como el de Bolivia, Venezuela, Ecuador y Cuba y aquellos procesos pseudoizquierdistas como lo sería Brasil, Uruguay y la propia Argentina. Por su parte, las relaciones e intentos de integración entre los países de un grupo u otro son explicados, como ya vimos, por los intereses de las potencias imperialistas que están detrás de cada uno de los gobiernos.

En relación a la postura que observamos entre los dirigentes del PO, el PCRCCC tiene una valoración mucho más positiva de las experiencias de Bolivia y Venezuela. Se destaca el fuerte movimiento de masas sobre el que dichos procesos se erigen, en consonancia con su concepción frentista, que va más allá de la postura obrerocéntrica visible en el planteamiento del PO. Sin abandonar el clasismo, y a partir de la importancia que posee la variable del imperialismo en su esquema político, los contenidos nacionalistas de dichos procesos políticos son vistos con buenos ojos y altamente valorados.

Del mismo modo se vuelve a la comparación de estos casos políticos concretos con el modelo teórico de revolución que la organización propone para la Argentina, en 
donde la dicotomía revolución y reformismo es sustancial. Para el enfoque que ofrece la organización, el proceso de transformación aparece como necesariamente violento en tanto el camino de las reformas resulta necesariamente inviable.

\subsection{Movimiento de Unidad Popular (MUP)}

En consonancia con la línea política que venimos observando en esta organización, el escenario político latinoamericano es visto con gran expectativa y se destacan en él, los cambios respecto a la hegemonía de los modelos neoliberales de las últimas décadas. Para Martelli el neoliberalismo en América Latina implicó un fuerte retroceso en términos de integración e igualdad social, lo que llevó a la generación de diversos procesos políticos que coronaron en presidencias anti -o posneoliberales, y que además apuestan a un proceso de integración regional que es visto como necesario y fuertemente positivo.

Lo que pasa en América Latina es consecuencia de múltiples factores. Uno es que ha sido uno de los lugares en los que se había alcanzado cierto grado de desarrollo (económico, político, social y cultural), a diferencia de Asia y África, por el cual, las recetas neoliberales provocaron un malestar y un dolor colectivo, una desvalorización colectiva del neoliberalismo y del capitalismo como quizás no se generó en otras partes del mundo.(...)

Esto viene sumado a que EEUU saca su mirada de acá, permite cosas que en otro momento hubieran sido impensadas, como que gane Lula en Brasil, o que se consolide lo de Chávez. Se han encontrado con sorpresas... me parece que es una sorpresa lo de Kirchner. Me parece que cuando quisieron reaccionar ya había un bloque de poder en vías de consolidación difícil de dañar, difícil de golpear. (Martelli, 2007)

Mientras que, como veíamos, el PO deslizaba fuertes críticas a los procesos venezolano y boliviano por tratarse de "nacionalismos" y no ser consecuentemente revolucionarios y la CCC-PCR ponía reparos respecto al intento de "cambiar las cosas por dentro" y a los "elementos reformistas", la postura del MUP no escatima elogios para dichos procesos y a la vez busca equivalenciarlos como parte de un mismo proceso político regional. En este sentido señala la importancia de que se profundice la integración económica y política para consolidar el bloque regional; objetivo estratégico y central para el avance de cada uno de los procesos políticos nacionales que buscan revertir los modelos neoliberales en el continente. Como veíamos en otro apartado, la figura de Kirchner resulta central en tanto articulador/mediador de las posiciones más distantes.

En definitiva, creo que para avanzar en la integración hay que avanzar en 2 sentidos. Primero integración económica: transformar a la región en base a un modelo desarrollo que haga que no haya posibilidades de desarrollo por separado. Que acá, venga quien venga, sepa que Argentina y Brasil no se pueden pelear. Porque estamos atados económicamente de una manera que es indestructible.(...) 
Y después, la integración política, la búsqueda de una identidad colectiva común. Que es lo que Chávez tanto hincha las pelotas. La recuperación del congreso de Panamá del año 13, el proyecto de la gran Sudamérica. Traicionado acá por Rivadavia que dijo que los destinos de Argentina iban a estar atados a los de EEUU, no a los de Sudamérica. Esta es mi visión de lo que está pasando, que se la mire por donde se la mire, es espectacular... (Martelli, 2007)

Por último, y en claro contraste con las críticas señaladas por las otras organizaciones, el secretario general de esta formación desliza ciertos reparos respecto del proceso político venezolano en relación a la alta velocidad con la que el presidente Chávez encara las transformaciones en su país ${ }^{72}$. No se discute el sentido o la dirección de dichas modificaciones sino los "tiempos políticos" y los riesgos que implican desatender ciertas variables que hacen a la viabilidad de los procesos políticos de transformación social. Se hace hincapié en los "diferentes tiempos" con los que avanzan los distintos procesos y las posibles desarticulaciones y sus negativas implicancias políticas.

\title{
6.4. Frente Popular Darío Santillán
}

El panorama latinoamericano es visto en términos generales como bueno, en el que se destaca la existencia de gobiernos que permiten el avance de procesos de integración entre los movimientos sociales que militan en cada país. Hay una especial diferenciación entre lo que son los gobiernos y el rol de los movimientos sociales. El tipo de articulación entre los movimientos sociales autónomos y los diferentes gobiernos que se proclaman progresistas, de izquierda o centro izquierda es determinante para distinguir al interior de ese conjunto unos gobiernos de otros. Así señalan en su página web:

\begin{abstract}
Latinoamérica está viviendo [un momento] muy especial de auge de los movimientos sociales y algunos procesos políticos que nos parece necesario diferenciar. Por ejemplo, aunque son todos partes del Mercosur no nos parecen equiparables los gobiernos de Argentina, Brasil, Uruguay, Chile, Bolivia y Venezuela. El rasgo diferencial en todos los casos nos parece es la incidencia que están teniendo y pueden tener en el futuro los movimientos sociales autónomos en el rumbo político de las decisiones de los gobiernos. En el caso de Brasil, la Argentina, Uruguay y Chile, por la propia actitud de los gobiernos hacia los movimientos sociales autónomos, no vemos posibilidades que se supere un neoliberalismo "progresista". Calificamos los procesos de Venezuela y Bolivia como procesos abiertos y por lo tanto nos generan expectativas. Nuestra vinculación internacional no es con gobiernos, sino con movimientos sociales y políticos. (FPDS, 2007
\end{abstract}

\footnotetext{
${ }^{72}$ “Creo que Chávez va muy rápido, que las trasformaciones en Venezuela van a un paso muy acelerado, que van con esas transformaciones Nicaragua, Ecuador y Bolivia y que el imperialismo ve que puede meter una cuña entre lo que es el ALBA y el MERCOSUR, entre Lula y Chávez, entre Bachelet y Chávez. Creo que esa es una de las debilidades, los tiempos con los que avanza un proyecto y otro." (Martelli, 2007)
} 
Es decir, la valoración política que se hace de los diferentes procesos políticos remite a la vinculación de los gobiernos con los movimientos sociales de su país, esto es, hasta qué punto los gobiernos se apoyan en movimientos sociales populares que legitiman y direccionan el rumbo de cada proceso. En este sentido destaca Obregón que la integración no debe reducirse a los gobiernos, sino que se debe trascender a partir de la integración de los movimientos sociales populares y autónomos de cada país. Esa sería la integración más deseable y superadora:

Nosotros tenemos relación con organizaciones de Venezuela, con el frente campesino Ezequiel Zamora que tienen el mismo planteo que nosotros: vincular las experiencias de los movimientos; que los gobiernos se vinculen, pero hay que tratar de trascenderlo. Hacerlo no es tan fácil. (Obregón, 2007)

Como puede verse, hay claras diferencias con otros discursos más allá de las similitudes. En general hay una valoración positiva de los procesos de Venezuela y Bolivia en la que coinciden casi todos con las salvedades ya mencionadas. Por el lado de los otros países -Brasil, Uruguay y Argentina-, la crítica es mucho menos radical que la de otros discursos ya que no son considerados como enemigos de los procesos de integración latinoamericana -como lo señalan discursos como el del PO o el del PCR-CCC- y hasta se reconoce que la presencia de varios de estos presidentes (Kirchner, Lula, Tabaré Vásquez) es preferible a las opciones de derecha que aparecen como alternativas. Siempre en la lógica centrada en los movimientos sociales, Obregón señalaba:

Uno lo que puede pensar es que la presencia de algunos de esos presidentes, en algunos casos, puede dar un poco más de aire para el crecimiento o la consolidación de las organizaciones, porque la variable represiva es menor... etc. (Obregón, 2007)

\subsection{MPR-Quebracho}

El escenario latinoamericano es visto en términos generales como muy promisorio, en el que se ve un gran avance de los sectores populares al interior de cada uno de los países en cuestión. Siguiendo la perspectiva objetivista que veíamos más arriba, se pone un gran énfasis en resaltar el momento histórico por el que está atravesando el continente, que va mucho más allá de las individualidades que ejercen hoy el gobierno de los distintos países del continente.

Latinoamérica me parece que está en el marco de ese proceso histórico. Nosotros decimos que es la hora de Latinoamérica. (...) El momento latinoamericano es un momento en el que el pueblo, los proscriptos, se van metiendo de prepo en los Estados y aparecen hombres que los intentan canalizar. (...)

Los que van exclusivamente son Fidel, Chávez, Correa y Evo. Nosotros no miramos la política desde los hombres. (...) Los hombres tienen precio. Los hombres son hombres, si no tienen precio, tienen 
debilidades humanas, temores. Los que no tienen temores, o los que tienen la sabiduría son los pueblos, no los hombres. (Esteche, 2007)

La división del espacio político latinoamericano incluye la distinción de tres grandes grupos, las "democracias restringidas", los países en los que se da el "encuentro de las masas con la política", y por último las "colonias imperiales". En el segundo de los grupos se encuentran los países ya nombrados donde se depositan las expectativas más importantes, a la vez que se señala que estarían acercándose a dicho grupo los casos de Perú y Paraguay. Este grupo de países es considerado como un conjunto de mojones antiimperialistas, los que no están exentos de contradicciones y limitaciones. (Shinzato-Zanzioth, 2007:194)

Luego están las "democracias restringidas", que incluye a Argentina, Chile, Uruguay y Brasil y que no cuentan con aquel rasgo que se señala en el grupo anterior. En el mantenimiento de la perspectiva objetivista se valora muy positivamente al Frente Amplio uruguayo, "una expresión genuina, democrática, formidable" (Esteche, 2007), pero se cataloga a Tabaré Vásquez como un traidor a sus postulados históricos y como la expresión más arquetípica -junto con Bachelet- del pro imperialismo. ${ }^{73}$

Sobre el caso brasilero se lo cataloga como un "subimperialismo" de la región que se ha recostado sobre la burguesía industrial paulista y que "juega para Brasil". En la misma línea también se señala que a Lula "le molesta Chávez, Venezuela. Le molesta Bolivia, en sus intereses" (Esteche, 2007). De este modo no sólo se mencionan diferencias entre un grupo y otro, sino también contradicciones y potenciales enfrentamientos entre países que en otros espacios y temáticas se muestran con intenciones de integración, colaboración y apoyo mutuo.

En líneas generales vemos en esta caracterización el mismo esquema de diferenciación entre los países que están atravesando procesos políticos auspiciosos y aquellos países que no. Las valoraciones de estos países son más claras y definidas que las que encontramos en otros discursos, partiendo de la base de reconocer las contradicciones y limitaciones, pero como parte de todo proceso político y no por causa de "equivocar el camino". Respecto a las "democracias restringidas", no aparecen valoraciones positivas sobre ellas, en tanto la explicación de los procesos de integración regional se circunscribe a la intencionalidad e injerencia de Venezuela y su gobierno. ${ }^{74}$

\footnotetext{
${ }^{73}$ Se nos ocurre preguntarnos ¿Por qué Chávez es el resultado genuino del avance del pueblo y Tabaré Vásquez no? ¿Cuál es el criterio para establecer que determinado personaje representa fielmente la "la sabiduría de los pueblos" o no?

${ }^{74}$ Así nos parece cuando se destaca centralmente "la ofensiva diplomática que está llevando Chávez" (Shinzato y Zanzioth, 2007:194) o cuando sobre el papel de Kirchner en las relaciones con Venezuela se decía "No es virtud de Kirchner, es una virtud de Chávez" (Esteche, 2007).
} 


\subsection{MTD - Aníbal Verón}

Para Daffunchio la evaluación del contexto latinoamericano es claramente positiva y auspiciosa. Se destacan en términos generales, todos los procesos que se están desarrollando como un avance de los sectores populares, donde por supuesto aparecen excepciones.

Siguiendo lo visto hasta ahora, se destacan especialmente los procesos políticos de Venezuela, Bolivia y Cuba en primer lugar, como casos paradigmáticos en los que se observan con más claridad el avance de los sectores populares. En un segundo orden aparecen menciones para las experiencias de Ecuador, Nicaragua y expectativas sobre el posible triunfo de Lugo en Paraguay. Todos estos son vistos como "procesos interesantes", sobre los que se puede esperar buenas experiencias.

Se hace una mención sobre el caso de Colombia, en particular sobre las declaraciones de un dirigente de las FARC sobre la disposición de la organización de participar en gobiernos de tipo socialdemócrata, cuestión que es positivamente valorada: "Que una guerrilla tan cerrada como la colombiana, que plantee eso hoy..." (Daffunchio, 2007). De este modo se vuelve a valorar la capacidad de flexibilizar ciertos posicionamientos y la disposición a la apertura.

Luego aparecen los casos de Brasil, Uruguay, Chile y Argentina. En líneas generales se critica la falta de decisión para avanzar en procesos políticos de corte popular al estilo de los mencionados en primer orden. Los casos de Brasil y de Uruguay se ven como defraudaciones o decepciones, lo que, a diferencia de otras miradas más peyorativas, implica una inicial expectativa. Se le critica una "idea muy paisana de la política latinoamericana" que privilegia las cuestiones particulares de cada Estado sobre una idea más regional. (Daffunchio, 2007)

Por último, tanto el caso chileno como el argentino son vistos como exponentes de "ese estilo de socialdemocracia que en realidad no resuelve un carajo" (Daffunchio, 2007), es decir experiencias que se enmarcan dentro de lógicas políticas que establecen límites a la posibilidad de avanzar en procesos políticos como aquellos mejor valorados. De cualquier modo, no hay una visión absolutamente negativa, al estilo de las caracterizaciones de "enclaves imperialistas" que aparecían en otros discursos, hasta tal punto que se reconoce como positivo el papel de Kirchner en el escenario latinoamericano, principalmente por ser funcional al proyecto que encabeza el presidente venezolano.

En resumen, la valoración general es muy positiva sobre el momento político del continente. Se diferencian distintas posturas entre los países más avanzados en este sentido y los que no. No hay críticas a los casos boliviano y venezolano ya que se manifiesta un respeto por las experiencias políticas de cada caso, con sus 
especificidades, más allá de cualquier paradigma teórico que se quiera usar para evaluar su desempeño. Asimismo se abren expectativas con los casos ecuatoriano y paraguayo como posibles avances en el proyecto regional. Del mismo modo, los casos de Brasil, Chile, Uruguay y Argentina son criticados por no estar en la sintonía o "a la altura" de los otros, pero no son catalogados como "elementos del imperio" o definiciones por el estilo que sí aparecen en otros discursos.

\subsection{Movimiento Teresa Rodríguez}

En torno a la valoración del escenario político continental se destaca en términos positivos la "lucha de los pueblos" que han protagonizado toda una serie de movimientos insurreccionales, volteando gobiernos, mostrando su malestar ante las políticas neoliberales que hegemonizaron los últimos años en América Latina. Sin embargo, se distingue lo que sucede con los gobiernos, con las "direcciones políticas", que son criticadas por mantenerse en lógicas reformistas que impiden la profundización de los procesos revolucionarios de acuerdo a los cánones que establece el marco ideológico. Así lo planteaba Martino:

En la Patria Grande hay signos muy alentadores. Hay una insurrección de los pueblos hace rato, que ya tiró varios gobiernos abajo. Hay un giro a gobiernos de carácter popular. Venezuela, Ecuador, Bolivia, Uruguay... El problema es que las direcciones políticas, el carácter reformista... el carácter no proletario -diría yo- los coloca en una encrucijada. Que tiende a que, si no aparece una construcción por fuera, desde ahí pero que supere esos planteos, termine arrastrando al grueso de esta rebeldía a la decepción. (Martino, 2007)

Desde esta perspectiva los diferentes procesos políticos que se vienen desarrollando en el continente son analizados a partir de los principios ideológicos del marxismo-leninismo, entre los que la disyuntiva reforma/revolución adquiere un peso determinante y es aplicada de un modo rígido, con una plena fijación de sentido sobre lo que se entiende con ambos conceptos. Así se observa con preocupación cierta flexibilidad y heterodoxia que aparece tanto en los casos brasilero o uruguayo, como en Bolivia, Venezuela y Cuba. Más allá de las trayectorias militantes de cada uno de los dirigentes políticos en cuestión, las que son reconocidas y valoradas, se plantea que en la medida en que se mantengan en lógicas reformistas, no lograrán desarrollar verdaderos procesos de transformación, y en definitiva, perecerán y fracasaran por su "carácter no proletario", por no ser lo suficientemente consecuentes y audaces como para llevar adelante los cambios revolucionarios. Así lo plantean en un artículo de su publicación Todo o Nada:

"El Che plantea de manera tajante que en el actual grado de desarrollo de las fuerzas productivas de la sociedad, en nuestros países se desarrolla la Revolución Socialista o lo que nos espera por delante es 
una caricatura de revolución. Lo que a la larga termina no solo en fracaso, sino también en tragedia, como pasó tantas veces." (Todo o Nada, 2006:9).

Desde esta postura aparecen comentarios sobre las experiencias de los distintos países. Sobre el presidente brasilero Lula Da Silva se rescata su pasado, su trayectoria, pero a la vez se lo menciona como un claro ejemplo de cómo "la maquinaria te termina modificando a vos". El dirigente del Frente Amplio uruguayo, "Pepe" Mujica, también es criticado en el mismo sentido, como un militante del "capitalismo en serio". Pese a ser diferenciados respecto a estos casos en algún punto, los casos de Bolivia y de Venezuela también atraviesan el mismo problema central respecto a los limites del reformismo. Sobre Bolivia se crítica las declaraciones del vicepresidente Álvaro García Linera sobre la importancia de desarrollar un "capitalismo andino", a la vez que se crítica la actitud del presidente Evo Morales de negociar en el parlamento con el PODEMOS, el "partido de los grandes empresarios" sobre el tema de la asamblea constituyente. De Cuba se expresa la preocupación por el rumbo que seguirá el país luego del "paso al costado" de Fidel Castro, ya que su hermano Raúl "planteó que por ahí lo ideal para Cuba seria orientar su economía tipo China..." Por último, respecto a Chávez, Martino nos decía:

"Yo lo veo como un líder nacionalista, populista. Populista en el sentido que no tienen la visión clasista. Para mí Chávez es Perón. No dudo que el pueblo venezolano está mucho mejor ahora, que avanzó la salud, que avanzó educación. (...) Pero eso no es para mí todavía el socialismo. Y no se está construyendo el socialismo. Perón también abrió las unidades básicas, llenó de unidades básicas. No es exactamente el socialismo." (Martino, 2007) ${ }^{75}$

En resumen, observamos en el discurso de Martino -que se condice con la publicación de la organización- un fuerte peso de los esquemas lógicos del marxismoleninismo, en especial del tema de la reforma vs. la revolución; esto es, las características específicas -la forma- que debe adquirir el proceso de transformación. Si bien se establece una distinción entre los distintos presidentes ${ }^{76}$, la disyuntiva revolución/reforma aparece como el criterio evaluador por excelencia. En este sentido, los procesos de transformación "más avanzados" se mantienen al interior del espacio reformista, es decir, constituyen experiencias que, al no avanzar en la destrucción del Estado burgués y construir un sistema político administrativo nuevo y adecuado para

\footnotetext{
75 Más adelanta señala: "Lo de Chávez puede existir un tiempo, pero no puede seguir existiendo... Además Chávez tiene a favor que hoy petróleo pegó un salto. (...) Porque hay una coyuntura particular, y esa coyuntura particular, no lo jode al grueso de la burguesía venezolana. No es que la está jodiendo. La burguesía venezolana está acompañando eso. El día de mañana... Es exactamente lo que era Perón." (Martino, 2007).

${ }^{76}$ Preguntamos a Martino (2007) sobre el carácter positivo o negativo de la presencia de cada presidente en sus respectivos países en relación al contexto latinoamericano. Hugo Chávez, Evo Morales y Rafael Correa fueron catalogados como "positivos"; Kirchner "si lo comparo con Menem es positivo"; mientras que Lula Da Silva, Tabaré Vásquez y Bachelet son catalogados como "negativos".
} 
las transformaciones que se pretenden llevar adelante, están próximas al fracaso y/o a la tragedia.

\title{
6.8. Barrios de Pie (Libres del Sur)
}

En el discurso de MBP-LS la cuestión del fortalecimiento de la unidad latinoamericana aparece como uno de los ejes más destacados, además del apoyo a las experiencias políticas consideradas más avanzadas en términos de transformación social. Así plantean:

“3) Estamos por la Unidad Latinoamericana. 4) Como así también por la defensa de la Revolución cubana, de la Venezuela Bolivariana y de la Bolivia de Evo Morales, frente a toda agresión de los EEUU. 5) Propugnamos la ampliación y consolidación del Mercosur; y la creación de un parlamento del mismo que contribuya a la integración y a resolver en un marco de unidad sus conflictos." (LS, 2008)

Ya veíamos más arriba que se destacaba el rol de Kirchner en el plano internacional y en especial en el latinoamericano, haciendo explícita la valoración al apoyo respecto del gobierno de Chávez. Los distintos procesos políticos de la región son vistos con buenos ojos y se los concibe como partes de un todo, cada uno con su rol, pero "todos tirando para el mismo lado". En este sentido se está lejos de la caracterización presente en otros discursos que ubica a los gobiernos de Brasil y Argentina tanto como ajenos u opositores al proceso de integración regional, como de meros oportunistas o "idiotas útiles". Para Baigorria:

\begin{abstract}
"el discurso neoliberal se quebró en el conjunto de Latinoamérica, o en la mayoría de las sociedades que la conformamos. Que el proyecto nacional de la Patria Grande todavía está en un retraso muy importante. Pero que ha pegado un avance en los últimos 4 o 5 años, fundamentalmente a partir de la aparición de Chávez, consolidado después con lo de Evo, fortalecido por lo de Lula y Kirchner. Fuertemente ahora avalado por lo de Correa en Ecuador. (Baigorria, 2007)
\end{abstract}

Este avance en la consolidación del "proyecto nacional de la Patria Grande" aparece como un hecho auspicioso y así es visto. Las excepciones que destaca Baigorria son las de Uruguay y Chile, ambos países con gobiernos de centro izquierda, que no vienen acompañando satisfactoriamente este proceso. Para el caso uruguayo destaca que justamente su rol en la política internacional es el principal eje de discusión, el tema a resolver de su política, como lo es lo económico para Brasil y la reforma política para Argentina. El debate en torno a esa cuestión es "el problema de primer orden", es lo que "los acerca o los aleja de un proceso sudamericano de emancipación". El caso de Chile aparece criticado con más claridad, caracterizado como el principal "contrapeso" de ese proceso. Para Baigorria están "lejos de contribuir a la unidad de los países latinoamericanos" y constituyen "una cabeza de 
playa de los yanquis en Sudamérica". Esta posición geopolítica es explicada por cuestiones de orden histórico, que obedecen a una situación heredada, en tanto la presidenta Bachelet aparece presentada debatiéndose sobre qué rumbo tomar frente a esta cuestión. (Baigorria, 2007)

\subsection{El campo popular latinoamericano}

Quizás la utilidad de este apartado esté en observar los posicionamientos de las diferentes organizaciones respecto a procesos políticos concretos que suelen ser considerados de izquierda, centro izquierda o progresistas. De esta manera a partir de casos reales y tangibles, podemos cotejar algunas de las categorías que hasta aquí sólo se presentaban en términos teóricos sin ejemplos empíricos para ser contrastadas. Surgen aquí matices que en otros tópicos se mantienen ocultos.

Hay un consenso general en establecer distinciones y agrupar a las diversas experiencias en categorías diferentes: por un lado están las que podemos llamar más avanzadas como Cuba, Venezuela, Bolivia y Ecuador, luego vendría el grupo de las menos avanzadas: Brasil, Argentina, Nicaragua, Paraguay, Uruguay y Chile y finalmente las experiencias de Colombia, México y Perú, unánimemente consideradas como exponentes del eje "neoliberal pro-norteamericano".

Si construimos una escala -dejando de lado el tercer grupo- sobre la valorización de estas experiencias respecto a su aporte de lo que podemos llamar el proceso de emancipación regional, podemos ubicar a las distintas organizaciones en una gradualidad que puede ser útil. Para simplificar utilizaremos en la confección de un cuadro los casos de Venezuela y Bolivia para referirnos a los más avanzados y los de Brasil y Argentina para el otro grupo.

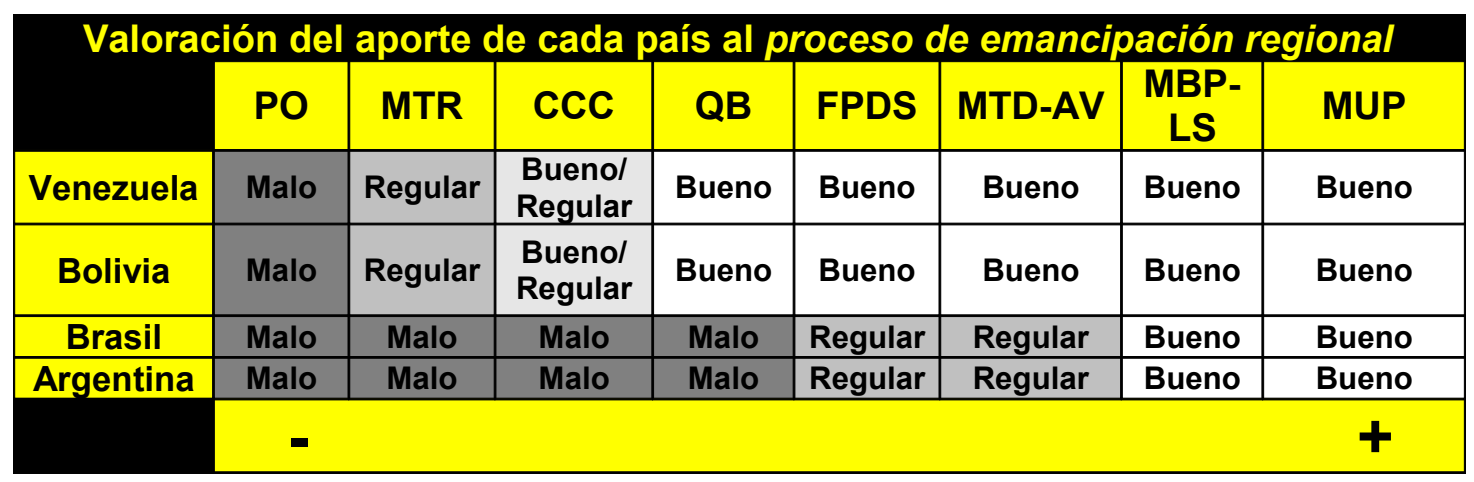

Como puede observarse en el cuadro, encontramos las valoraciones más positivas del contexto regional desde las organizaciones oficialistas, pasando gradualmente por distintos posicionamientos hasta llegar a una caracterización fuertemente negativa como la que plantea el PO. No existen grandes diferencias entre 
las organizaciones oficialistas, las que destacan especialmente el rol de los países menos avanzados, tornando menos visibles las distinciones entre un grupo y otro y haciendo hincapié en la función que cada uno posee en el proceso regional. Para el MTD-AV y el FPDS la distinción entre los más y los menos avanzados es más clara y nítida, siendo las primeras experiencias fuertemente valoradas, mientras que las segundas aparecen presentadas con fuertes limitaciones, aunque no deja de reconocérseles cierto rol positivo en el contexto regional. Para el MPR-QB la distinción se torna más poderosa aún, destacando el papel perjudicial que los menos avanzados tienen en el proceso de la región, presentando una relación de oposición entre un grupo y otro. La CCC-PCR adhiere a esta valoración, pero además establece algunos reparos respecto a las características de los más avanzados, los que desde su punto de vista, deberían pasar a una etapa de franco enfrentamiento entre las clases sociales y despojarse de los elementos reformistas que en ellos sobreviven. EI MTR critica con más énfasis los rasgos reformistas y nacionalistas que caracterizan a estos procesos lo que lo lleva a reducir notablemente sus expectativas al respecto. Finalmente, el PO además de coincidir con el grueso de las críticas vinculadas al reformismo y al nacionalismo que hace el MTR, considera que estas experiencias obstaculizan y actúan en detrimento de las verdaderas expresiones revolucionarias de las clases trabajadoras.

Nos parecía oportuno graficar los distintos posicionamientos marcando los matices que permiten establecer una gradualidad en una determinada escala comparativa. Se observa como van operando los diferentes elementos identitarios que venimos analizando en un posicionamiento concreto que deriva en matices ausentes en otros tópicos. ${ }^{77}$

Uno de los objetivos que nos planteamos en este trabajo tiene que ver con la posibilidad de profundizar la caracterización de los elementos político-ideológicos que conforman los discursos identitarios de las distintas organizaciones. Un dato que resulta interesante para observar en este sentido es el de las diferencias que se visualizan en los posicionamientos de cada una de las organizaciones que se definen

\footnotetext{
${ }^{77}$ En líneas generales, el conjunto de los presidentes del bloque regional que definieron su alejamiento de la estrategia del ALCA promovida por la administración norteamericana, parece desarrollar lazos de integración que debilitan las fronteras que les son establecidas por las lecturas de las organizaciones que dicen sentirse representadas y alineadas con algunos de ellos. Quizás la apertura y la flexibilidad que demuestran estos países en sus estrategias regionales constituyan un indicador de la magnitud de las diferencias que se le adjudican, pero sobre todo de la tolerancia con que es aconsejable encararlas en pos de objetivos superiores. Dicho de otro modo, pareciera que las diferencias que pueden señalarse en un nivel teórico-ideológico se ven fuertemente debilitadas en el ejercicio político concreto, en la gestión de los asuntos públicos. Es decir, en los posicionamientos concretos, las diferencias identificadas, se ven fuertemente atravesadas por el tipo de vinculación que se tiene con la gestión de los asuntos públicos. Se trata, aunque pueda parecer obvio, de dimensiones de análisis muy distintas, que deberían ser constatadas y puestas en consideración para pensar en instancias de articulación. Acaso sea un modo de matizar diferencias que en un plano teórico resultan irreductibles.
} 
como marxistas-leninistas. Si bien se trata de matices, tales diferencias remiten a elementos político-ideológicos que resultan de gran relevancia cuando se trata de pensar las posibilidades de articulación política.

La postura del PO que ve en cada una de las experiencias no más que continuidades y gobiernos que impiden el desarrollo de verdaderos procesos revolucionarios, da cuenta de las múltiples fijaciones de sentido que hemos podido observar hasta aquí, desde las cuales analiza y valora los procesos políticos concretos: las desviaciones respecto al "punto de llegada", al modo que debe adquirir la transformación y al sujeto político al que se apela en cada de estas experiencias devienen en diferencias difíciles de zanjar. El caso del MTR centra sus críticas básicamente en el modo de transformación social, lo que sin dejar de plantear su desacuerdo, lo separa visiblemente del planteo del PO. Es el mismo punto en el que coincide la CCC-PCR, pero en esta última la organización la cuestión nacional aparece entremezclada, como parte del camino ininterrumpido hacia el socialismo. De aquí que sus críticas sean menores a los casos más avanzados. Finalmente el MPR-QB no establece ningún reparo respecto de estás ultimas experiencias en tanto los tópicos donde observamos sus posturas más rígidas -principalmente la cuestión nacional y el modo que debe adoptar el enfrentamiento político- no se ven cuestionados por aquellas experiencias.

Por el lado de las organizaciones que identificamos con la izquierda heterodoxa, los planteos son similares. Las experiencias avanzadas aparecen claramente valoradas, mientras que las otras son criticadas pero al mismo tiempo se le valoran avances respecto a gobiernos anteriores. Tales posturas se corresponden con la ausencia de posicionamientos rígidos respecto a los principales tópicos que son considerados en la valoración de cada una de las experiencias. Esto les permite adoptar posiciones que sin dejar de marcar limitaciones y falencias, reconocen ciertos aportes al proceso regional.

Finalmente, las organizaciones cercanas al oficialismo tienden a homologar los distintos procesos, adjudicándoles diversos roles a los diferentes gobiernos y países. Los tópicos del discurso identitario sobre los que se establecen las definiciones más claras como la cuestión nacional encajan sin contradicciones en las valoraciones que llevan a cabo estas organizaciones sobre los casos menos avanzados. Mediante el conjunto de elementos político-ideológicos que configuran sus discursos, las diferencias entre ambos grupos de países, que resultan irreductibles para otras organizaciones, aquí son desestimadas. 


\title{
7. ESTADO, CLASE Y NACION
}

Nos interesaba observar qué tipo de concepciones aparecen respecto a elementos habituales que conforman los discursos identitarios de las formaciones políticas del campo popular. En este apartado buscaremos indagar el modo en que se articulan en el discurso la cuestión del Estado -y la política institucional-, de la clase lucha de clases, identidad de clase, etc- y la cuestión nacional -el peso de la nación y el tipo de apelación sobre ella.

\subsection{Polo Obrero (Partido Obrero)}

a. Estado y política institucional.

Respecto a la cuestión estatal, encontramos en las respuestas de los dirigentes una concepción del Estado atada a la tradición marxista según la cual se destaca su componente de parcialidad, es decir de salvaguardar, el Estado por sí mismo, los intereses de la clase capitalista. En este sentido, Pitrola señala:

\begin{abstract}
En esto los socialistas ya tenemos una larga tradición: el Estado no es neutro, el Estado defiende muy precisos intereses sociales. Por eso tenemos que 30 años después de que cayó la dictadura seguimos luchando contra la impunidad del proceso militar, porque es un Estado que ha tenido una continuidad. Los mismos intereses sociales que estuvieron con Martínez de Hoz, volvieron a gobernar con Menem y siguen gobernando ahora con Kirchner. Los capitanes de la industria, los banqueros, los exportadores terratenientes. Con más o menos matices, con péndulos, pero son los intereses sociales que están detrás de un Estado. Esto en primer lugar. (Pitrola, 2007)
\end{abstract}

Es decir, el Estado, es un Estado burgués, forma parte de su naturaleza, de su esencia, responder a determinados intereses. Los cambios de gobierno, en tal sentido, son cuestiones de forma, mientras los contenidos del propio Estado se mantienen. El desafío entonces es el de "cambiar la naturaleza del Estado", y en este sentido la opción parlamentaria aparece como un camino para ese cambio.

Más allá de que pueda resultar llamativo esencializar al aparato estatal y optar por construir políticamente al interior de sus instituciones, a través de sus mecanismos, Pitrola es contundente en enfatizar la importancia de la labor parlamentaria, destacando la falta de una presencia legislativa por parte de la izquierda revolucionaria, en tanto "la izquierda" representada (Lozano, ARI, FREPASO) "son parte del régimen".

\section{b. Clase y lucha de clases}

Sobre este punto ya fuimos observando claros posicionamientos al respecto. El Partido Obrero tiene como objetivo constituirse en el partido de la clase obrera, 
representando sus intereses, en tanto dicha clase es considerada como "la clase que es capaz de realizar los cambios revolucionarios". Es decir, por un lado encontramos que la ubicación económica de los sujetos -la clase- se condice con determinado papel político, con una determinada misión histórica. En segundo lugar y en la misma línea, hay una identificación plena entre el partido y la clase, identificación que descansa en la representación política de los intereses de clase -sujeto económico. En tercer lugar, el PO es una de las organizaciones, que a diferencia de muchas otras logra representar los genuinos intereses que posee la clase trabajadora.

La cuestión política, por tanto, se circunscribe al enfrentamiento de clases, marcando claramente los polos de la contradicción y siendo fuertemente severos con quienes se asocian, cooperan o articulan con actores políticos que no representan dichos intereses de clase. Una vez más, la cuestión de la independencia de clase es central, dando cuenta de una concepción de la sociedad claramente dividida por el enfrentamiento entre sus clases fundamentales. La cuestión fundamental es determinar "qué clase social va a gobernar en la Argentina" (Pitrola, 2007), es decir los que gobiernan son las clases, las que son directamente representadas por determinados partidos políticos.

\section{c. La cuestión nacional}

La llamada "cuestión nacional" incluye una serie de elementos diversos y ambiguos, más si trabajamos en el marco teórico que planteamos, según el cual los significantes nunca son concebidos como plenos, sino sujetos a operaciones articulatorias, hegemónicas, que le otorgan distintos significados. En el caso de la cuestión nacional, nos interesaba indagar sobre el peso y la centralidad de la nación como significante presente en los discursos identitarios de las formaciones políticas.

En el caso del $\mathrm{PO}$, vimos que la cuestión nacional está enteramente subordinada a la cuestión de clase, es decir la lucha política, los objetivos políticos de la organización están enteramente orientados de acuerdo a la lucha de clases, mientras que la nación no aparece interpelada como componente identitario. Al contrario, muchas de las críticas hacia otras organizaciones y procesos políticos, se centran en señalar la primacía de lo nacional sobre lo clasista. El caso más visible de esto quizás tiene que ver con las críticas a los procesos de Bolivia y Venezuela, los que son etiquetados como experiencias nacionalistas $y$, por tanto, con fuertes limitaciones y objetivos distantes de los verdaderos procesos de cambio social orientados hacia el socialismo. En este sentido Pitrola señala:

"los gobiernos de la burguesía nacional ya los tenemos. Ya los tenemos incluso, históricamente, muy agotados en América Latina. El nacionalismo es un fenómeno que dio todo lo que podía dar. 
Particularmente en los 50, con Haya De La Torre, con Perón. Dio lo que tenía para dar el nacionalismo. Estos nacionalismos son una caricatura histórica de aquellos. No vamos a volver a pasar por la experiencia. Tenemos que superarlos, por supuesto con un programa y en un proceso de construcción política de una herramienta de los trabajadores." (Pitrola, 2007)

\title{
7.2. Corriente Clasista y Combativa
}

\section{a. Estado y política institucional.}

La visión sobre el Estado que definen los dirigentes del PCR-CCC se enmarca dentro del esquema clásico marxista según el cual aquél es el instrumento de las clases dominantes, es decir de la burguesía. Desde esta perspectiva, la estrategia política incluye la consigna de destruir el Estado burgués para reconstruir las instituciones administrativas con el control y los objetivos de la clase trabajadora:

\begin{abstract}
Desde que la sociedad se divide en clases el Estado ha sido el instrumento de las clases explotadoras para mantener su dominio sobre las clases explotadas y asegurar su poder. Esta máquina estatal burocrática y represiva (incluidas sus instituciones "representativas" y la división de poderes) no le sirve al pueblo. Debe ser destruida, poniendo en su lugar nuevas instituciones de un Estado de las clases revolucionarias. (PCR, 2004)
\end{abstract}

Tal concepción del Estado se asocia con una estrategia política que propone como única vía de transformación social, la vía revolucionaria, la lucha armada, reeditando de manera tajante la dicotomía revolución-reforma. Así lo señala el programa del partido:

La cuestión del Estado de las clases dominantes, el camino revolucionario de su destrucción o el camino reformista de ganar espacios dentro de él -y como consecuencia la vía armada o la vía pacífica para conquistar el poder- ha sido, desde el Primer Congreso del Partido Socialista de la Argentina en 1896, la línea divisoria entre marxistas y revisionistas, entre revolucionarios y reformistas.

Y luego señala:

La insurrección armada combinada con las modalidades propias de la lucha armada en el campo (guerrilla rural y otras formas de combate campesino) que pueden producirse antes, durante o después del momento insurreccional, es el único camino que permitirá acabar con el poder del imperialismo, los terratenientes y la burguesía intermediaria. (PCR, 2004) (las negritas son nuestras)

En tal sentido, la valoración sobre las instituciones políticas en general es fuertemente crítica y se establece directamente la lucha armada como camino ineludible para un proceso de transformación política de las características que la organización propone. En la misma línea, sobre la cuestión electoral, Ardura señala:

No somos anti electoralistas. Consideramos que lo que se abrió en el santiagueñazo no se ha cerrado. Por lo tanto, toda la etapa del santiagueñazo hasta ahora, solo participamos en una elección que fue en el 95 y consideramos que fue desacertado hacerlo. Y que hasta que este período no se cierre, no tenemos que participar. (Ardura, 2007) 
Si vinculamos está última cita con lo que señala el programa del partido, podemos concluir que la cuestión electoral aparece como una cuestión instrumental y circunstancial para una acumulación política de algún tipo, pero nunca como el verdadero camino hacia la transformación social. Anteriormente observábamos adjetivos descalificadores respecto a los que "legitimaban" el sistema con su participación electoral. De esta manera el sistema democrático electoral ("con sus instituciones "representativas" y su división de poderes") no recibe ningún tipo de valoración positiva en tanto que, en última instancia, impide una transformación revolucionaria real.

Por último cabe señalar que el Estado es visto con amplísimas facultades de dominación, al punto de que nada o casi nada escapa a su control. Una suerte de Estado omnipotente y omnisciente. Desde esta perspectiva se facilita la postura de centrar las críticas y responsabilidades en los sucesivos gobiernos y establecer una identificación total entre el gobierno y las clases dominantes. Algo de eso aparece en la fuerte acusación al gobierno nacional por la no aparición de López, en tanto se entiende que si no lo hizo fue por que no quiso y no porque no pudo. Otro ejemplo de esto lo da Ardura cuando señala:

Ellos son bien serios, ellos saben muy bien lo que pasa. Porque como tienen un agente del SIDE hasta en el ultimo poblado de 20 habitantes, en cada lugar del país, todos los días mandan un informe de que pasa con las masas. $Y$ él [Kirchner] recibe una carpeta a la mañana de Casirini, o del que esté, donde dice: ¿A ver que está pasando en Río Turbio?" Y al tipo le traen un paper y dice: "Mirá, hay estos 30 que están enojados, yo los escuche en el boliche hablando mal de vos" $Y$ esto es así. Saben. Las clases dominantes saben lo que pasa. (Ardura, 2007)

En definitiva, y en relación a la postura que observábamos en el PO, la visión de esta organización también ubica al Estado como un instrumento de la clase burguesa, (con un control casi total de lo que sucede) el cual debe ser destruido. Sin embargo en el $\mathrm{PO}$, eso no deviene en una estrategia necesariamente insurreccional y armada, como sí aparece en el planteamiento de la CCC-PCR.

b. Clase y lucha de clases.

En este punto, como veíamos más arriba, el programa del partido presenta un discurso que se enmarca dentro de lo que algunos llaman el modelo de "desarrollo desigual y combinado" según el cual las especificidades de los países subdesarrollados establecen la necesidad de desarrollar estrategias políticas de articulación entre diferentes sectores y clases sociales. De esta manera surge lo que Laclau y Mouffe llaman la enumeración comunista (2004:96) según la cual el espacio social aparece dividido de manera dicotómica en dos grandes bloques, el de los 
sectores dominantes y el del campo popular, al interior de los cuales se inscriben las diferentes clases sociales y grupos: campesinado, proletariado industrial, una sección progresista de la burguesía nacional, pequeña burguesía urbana, intelectuales, etc., de un lado y la burguesía intermediaria, imperialismo, etc., del otro. ${ }^{78}$

Este discurso complejiza el modelo tradicional de burguesía vs. proletariado presente en la Primera y Segunda Internacional, diferenciando nuevos actores al interior de cada polo e incorporando relaciones equivalenciales en la articulación de los diferentes actores. Un tópico central que acompaña esta concepción es el de la alianza de clases como estrategia de articulación al interior del bloque del campo popular. Esto no significa que se abandone el clasismo ni mucho menos, pero establece una diferencia significativa con el modelo que veíamos en el PO.

De todas maneras uno de los rasgos centrales de este modelo es que mantiene, más allá de la alianza de clases al interior del campo popular, un lugar privilegiado de dirección para la clase obrera industrial, acompañado con mayor o menor centralidad por el campesinado.

El único que puede ordenar esto son dos clases: el campesino pobre y el proletariado industrial, porque donde esos se aliaron hubo revolución. Rusia, Cuba, China, donde se aliaron hubo revolución. Sin esos dos, los sectores medios, el estudiantado, todo los que son aliados para revolución: plumas al viento. Van y vienen, dan vueltas. (Ardura, 2007)

Dicho de otro modo, la ampliación del espacio de articulación, la superación de la literalidad proletariado vs. burguesía, termina desembocando en - ¿retornando a?- la necesaria hegemonía de la clase obrera, del proletariado, en el marco de una alianza de clases. $^{79}$ Desde esta lógica, las alianzas de clase -similar a lo que observábamos sobre las alianzas con otras organizaciones del campo popular- adquieren un carácter meramente instrumental, en el marco de un modelo etapista, como queda expuesto en el programa del partido cuando se refiere a la relación con la burguesía nacional:

Desde nuestro Primer Congreso definimos nuestra línea de neutralizar a la burguesía nacional como clase. La política del proletariado hacia ella, en esta etapa de la revolución, es de unidad y lucha y apunta a su neutralización como clase. Esto implica una política activa para ganar a un sector de la burguesía nacional (los sectores patrióticos y democráticos), neutralizar con concesiones a otro sector, y atacar a la capa superior, al sector que se alía con el enemigo. (...) Incluso el sector de burguesía nacional posible de aliarse en determinados momentos a la clase obrera y a las fuerzas revolucionarias es vacilante, y cuando

\footnotetext{
${ }^{78}$ Un dato interesante es que en la enumeración de grupos y sectores que componen el campo popular aparecen definidos por cuestiones diferentes. Esto es, se habla del proletariado, del campesinado, pequeña burguesía urbana, es decir actores definidos por su ubicación económica y luego aparecen al mismo nivel actores definidos en función de rasgos de otros órdenes: nivel de instrucción (estudiantes secundarios y universitarios, "la intelectualidad"), grupos etarios (la juventud), de género (las mujeres). Sería interesante profundizar el tipo de relación que se establece entre estos órdenes heterogéneos que no aparece del todo claro en la enumeración que ofrece el programa.

${ }^{79}$ Reza el programa: "En nuestro país, el proletariado no solo es la fuerza dirigente sino también el principal contingente de las fuerzas motrices de la revolución." (PCR, 2004)
} 
nos unimos a él, debemos estar alertas, porque lo más probable es que, en el futuro nos traicione; y porque cuando se une a nosotros lo hace disputándonos la dirección de las masas oprimidas a las que influencia. (PCR, 2004)

Como veremos en las conclusiones, creemos que esta concepción sobre la articulación política entendida como alianza de clases, sumada la necesariedad de la hegemonía del proletariado - "dictadura del proletariado" incluida- establecen límites importantes en las posibilidades de desarrollar procesos de articulación política de alta intensidad.

\section{c. La cuestión nacional}

La cuestión nacional es un tema de gran centralidad en el discurso de esta organización. Como pudo verse en los apartados anteriores, el imperialismo actúa como un elemento excluyente para la explicación de toda una serie de elementos vinculados con el análisis político y con la estrategia que propone la organización. Así también lo señala Ardura:

\section{P: ¿Como aparece la Cuestión Nacional en la CCC? \\ $R$ : Para nosotros la cuestión nacional es fundamental. Si somos un país oprimido por el imperialismo, somos una nación oprimida. Es decir, hay una tarea de la revolución que es la liberación como clases, de liquidar a los monopolios, la burguesía intermediaria, los terratenientes y el imperialismo, y hay una tarea que es recuperar la independencia del país. Y cuando hablamos de independencia del país, hablamos de recuperar las empresas a manos del pueblo, la repatriación de las ganancias. (Ardura, 2007)}

Sin embargo, para el coordinador nacional de la $\mathrm{CCC}$, la cuestión de la independencia nacional y de la lucha en contra del capitalismo se han mezclado de un modo complejo y perjudicial a partir del concepto de capitalismo dependiente, fragmentando la lucha del campo popular desde la centralidad que cada formación política le adjudica a cada uno de estos antagonismos que atraviesan la sociedad. Concretamente, para Ardura se trata de una operación ideológica fraguada por los servicios de inteligencia rusos para neutralizar los procesos revolucionarios en el tercer mundo en el marco de su estrategia imperialista. ${ }^{80}$

De esta manera se reedita la discusión sobre la estrategia a seguir, el rol de la burguesía nacional, etc. En el planteamiento de Ardura -que también está presente en

\footnotetext{
${ }^{80}$ Señala Ardura: "Y los rusos como tenían que engañar a todos los revolucionarios del mundo de que ellos seguían siendo socialistas, pero en realidad eran imperialistas, en su academia de ciencias de Moscú estudiaron que palabritas teóricas, como había que revisar al marxismo, a la teoría revolucionaria para poder domesticar teóricamente a las organizaciones del mundo para que terminaran siendo serviles y utilizadas por ellos mismos, no en el juego independiente de la clase obrera para liberarse en cada país, sino en el juego de ubicar a los sectores populares detrás los sectores económicos, políticos y militares de ellos que estaban en disputa con los yanquis. Entonces allí introdujeron el concepto de capitalismo dependiente. Que ha hecho un daño... A veces cuando yo cuento el daño que han hecho esas dos palabritas es para horrorizarse: Capitalismo Dependiente." (Ardura, 2007)
} 
el programa del PCR- la preponderancia siempre es la lucha de clases, la lucha contra la burguesía y el establecimiento -como paso ineludible y necesario- de la dictadura del proletariado. Así, la alianza de clases que veíamos más arriba es estrictamente circunstancial y se somete a la revolución socialista. Es decir, más allá del acento en la cuestión imperialista y en la mención sobre la cuestión nacional, la estrategia política circunscribe sus objetivos al socialismo vía dictadura del proletariado. La independencia nacional y el rol que puede llegar a tener la burguesía autóctona se circunscriben a los objetivos clasistas. ${ }^{81}$

\subsection{Movimiento de Unidad Popular (MUP)}

a. Estado y política institucional.

En relación a la cuestión del rol de Estado y de la política institucional aparecen nuevas diferencias significativas entre la postura del MUP con las formaciones políticas de matriz más marcadamente marxista. En primer lugar se rompe con la identificación del Estado con las clases dominantes, con el poder en sí. Se destaca su rol de mediador entre las clases sociales, en particular entre la clase trabajadora y la burguesía. Así aparece como un espacio de disputa que juega y regula en el terreno de la sociedad civil con mayor o menor intensidad, beneficiando a unos o a otros actores. Nos permitimos citar un extenso fragmento de la entrevista donde quedan claras estas definiciones.

En determinados momentos de la historia el Estado puede ser progresivo o regresivo. Cuando el Estado se transforma en una traba para el avance de los intereses de la mayoría, es regresivo. Nosotros venimos de una situación en la que el Estado, desde la revolución industrial y la independencia norteamericana, era un elemento mediador de la disputa de clases. Es un elemento que partir de 1916, desde Yrigoyen, se transforma en una herramienta de la burguesía pero que tiene que aparecer como mediador en la resolución de los conflictos de clases. Y se transforma con el peronismo, en motor del desarrollo de la clase trabajadora. Vos fijate que ese Estado, desde el 55 en adelante, lo que han tratado las clases dominantes es de limar, de reducir la capacidad creadora del Estado para exponer a las clases humildes, frente al poder de las clases dominantes. (Martelli, 2007)

El punto de quiebre central tiene que ver con no adherir a la identificación total y automática del Estado con las clases dominantes económicamente. En un marco

\footnotetext{
81 Sin ser del todo claro, Ardura destaca la centralidad de la lucha anticapitalista y critica las desviaciones "nacional populares": "Y es lo que ha pasado en la Argentina con esas dos palabritas malditas que nos metió el imperialismo: capitalismo dependiente. Esto tiene un efecto práctico. Al considerar capitalismo, metemos en la misma bolsa, junto con la burguesía intermediaria del imperialismo, los terratenientes, metemos a todos los sectores burgueses. Por pequeños que sean. Todo tipo que explota a un obrero está en el blanco del enemigo. ¿En el capitalismo quien es el enemigo? La burguesía. Si este vecino de al lado tiene dos obreros es mi enemigo. Estratégicamente yo se que es mi enemigo, porque para hacer el socialismo voy tener que terminar con todos los burgueses. Punto 2: El concepto de dependiente, como es tan grande el enemigo, se le genera un problema. Hay que hacer socialismo de entrada, hay que derrotar a toda la burguesía: "SO-CIA-LIS-MO"." Ardura, 2007. Ver también nota n 44
} 
democrático -aunque más no sea electoral o formal- el Estado es un espacio de disputa que puede ser conquistado por grupos políticos que orienten su accionar a favor de los sectores más desprotegidos enfrentándose con los poderes económicos dominantes. Una vez más hay una fuerte valoración del peronismo, asociándolo al momento en que el Estado se constituyó en "motor de desarrollo de la clase trabajadora".

Desde esta perspectiva la contradicción política fundamental vuelve a ser la del campo nacional-popular vs. el campo liberal, en tanto el Estado liberal ("desde el 55 en adelante") justamente busca limitar el poder del Estado como regulador de la economía y principal promotor de la distribución del ingreso. Lejos de ser un enemigo y representante de los intereses de la burguesía, el Estado en la sociedad capitalista es una herramienta de control y regulación económica para revertir las tendencias regresivas de la economía. Es decir, no sólo no constituye un enemigo, un natural representante de los intereses de las clases económicas, sino que es la herramienta principal desde la cual encabezar el proceso de transformación social. En este sentido el MUP busca diferenciarse tanto de las posturas marxistas clásicas como de las llamadas autonomistas que no ven al Estado y a la política institucional como espacios centrales de transformación. ${ }^{82}$

El Estado es concebido como un actor más dentro de la sociedad, un actor político que puede estar asociado con unos $u$ otros sujetos y clases sociales y que sin duda posee herramientas y poder para avanzar en procesos de transformación social. Del mismo modo no se desconocen las limitaciones de dicho poder -la ineficacia e ineficiencia del aparato estatal- ni las dimensiones de los otros poderes que operan en el escenario social, muchas veces en contra del mismo Estado. ${ }^{83}$

\section{b. Clase y lucha de clases.}

Las clases sociales son actores claros y definidos en el análisis del MUP, pero el conflicto entre capital y trabajo no se resuelve necesariamente a través de un enfrentamiento frontal y total, mediante la socialización de los medios de producción vía dictadura del proletariado. No hay un conflicto irreductible entre ambas clases, sino

\footnotetext{
82 Haciendo alusión a su "pasado anarquista", Martelli señala: "Todos los que hemos propuesto que los cambios pueden realizarse sin el Estado, hemos fracasado. Porque el Estado es el único que tiene la herramientas para transformar desde la política pública para llegar a millones. Como experiencia formadora o como germen de poder, uno puede plantear el desarrollo de una tarea alternativa: un centro cultural, un comedor, una huerta comunitaria.. Eso te sirve como formación del que está en eso y como construcción de poder. Pero si querés modificar la cuestión cultural, es una política de Estado. Es como el Estado invierte en el desarrollo de la cultura para una disputa ideológica." (Martelli, 2007)

${ }^{83}$ En este punto hay un claro contraste con la concepción del estado omnipotente que aparece en el planteo del PCR-CCC. Señala el MUP en su página web: "La dificultad principal se basa en que el estado hoy tiene pocos resortes para intervenir en la producción, circulación y comercialización de bienes y servicios, lo que nos pone en una situación de desventaja respecto del mercado y nos obliga a correr desde atrás” (MUP, 2008)
} 
que se puede avanzar en un proceso de transformación social que promueva el desarrollo de la clase trabajadora limitando el poder de los sectores económicos dominantes.

De este modo, la lucha de clases no está ausente, pero no implica la eliminación del enemigo (la burguesía), sino su disciplinamiento mediante el Estado y la sociedad civil logrando establecer un modelo de integración social redistributivo e incluyente de los sectores populares. Se trata de una constante e inacabable disputa por lograr el mejor escenario en cuanto a relación de fuerzas se refiere. En este cuadro el Estado resulta una herramienta fundamental que puede ser usada.

Nosotros vemos que ni el Estado por su cuenta, ni las organizaciones por la suya, pueden resolver los principales problemas de la Argentina. Tiene que haber una interacción. Lo que nosotros decimos: el Estado militante. El Estado que borra la barrera entre pueblo y gobierno, porque son la misma estrategia. Se borra la idea de un lado y otro del mostrador. Eso construye una herramienta nueva que me parece muy poderosa, indestructible. Si pueblo, gobierno y Estado caminan en una misma dirección, la potencialidad es muy fuerte. Me parece que ese es el primer peronismo: es el gremio y el Estado en la búsqueda del mismo objetivo. Es la fuerza popular organizada y es la guita. Lo que mueve al país es la plata, la ley principal es la de presupuesto. Todo lo demás es engaña pichanga. (Martelli, 2007)

\section{c. La cuestión nacional}

A la hora de explicar los graves problemas de exclusión y desigualdad social que se registran en el país, el MUP hace especial hincapié en la cuestión nacional, esto es, en las desigualdades globales que se registran entre los países centrales y los periféricos, fuente de pobreza y de la propia desigualdad interna. Siguiendo los clásicos modelos de la teoría de la dependencia, se piensa en la soberanía nacional y en el desarrollo independiente de los países subdesarrollados como la senda por la cual transitar hacia un modelo país integrador e incluyente. Esta cuestión a la vez es acompañada por una visión regional, sostén fundamental para el éxito de esta empresa. Veíamos más arriba la clara valoración positiva de los diversos procesos políticos que se están desarrollando en Latinoamérica, los que son pensados como parte de un todo, un bloque regional latinoamericano que avanza en la búsqueda de la eliminación de las asimetrías globales.

\section{$P:$ ¿Cómo definís la Cuestión Nacional?}

$R$ : Tiene que ver con la realización de los intereses del conjunto de la nación argentina que confrontan permanentemente con los intereses de los imperios de turno. Hoy por hoy vivimos en un mundo en guerra: política, económica. Donde hay bloques que se disputan el control del mundo: los chinos, los rusos, los norteamericanos, los europeos, los japoneses... y que ven a los países periféricos como instrumentos de la realización de sus intereses. La cuestión nacional plantea que en conjunto, con los países que están en una situación como la nuestra, debemos construir una contrahegemonía, discursiva, política, económica y social. Me parece que tiene que ver mucho con lo que está 
pasando ahora en Latinoamérica: cómo paramos a Latinoamérica ante los bloques dominantes. (Martelli, 2007)

De este modo se apela a un sentimiento nacional que opera y establece un ellos y un nosotros. La nación, la Argentina, es un actor subordinado y explotado en el concierto de las naciones a través de los grandes capitales extranjeros, los que son respaldados por sus respectivos Estados y cuentan con la complicidad de gobiernos y ciudadanos locales. La apelación a lo nacional se orienta a la posibilidad de dirigir los destinos del país, al interior de un bloque regional -la llamada "Patria Grande"-, revirtiendo las desigualdades globales. Esta visión descansa en una concepción de la nación como un sujeto colectivo que es explotado por las potencias imperialistas, explotación que es responsable del deterioro y la precariedad al interior del país. Las riquezas nacionales deben ser protegidas y volcadas al propio país: menos empresas transnacionales y más empresas nacionales, públicas y privadas.

La diferencia que podemos aventurar entre este planteo y el del PCR-CCC es que en aquel los factores económicos externos terminan explicando lo político en casi todas sus dimensiones, y que además son absorbidos al interior de la contradicción burguesía-proletariado. La lucha antiimperialista es parte de una lucha contra el capitalismo ("en camino ininterrumpido hacia el socialismo"). Aquí, la desfavorable posición de la Argentina en el escenario global requiere de una fuerte y vigorosa burguesía nacional que ubique a la nación y a la región en pie de igualdad con los países centrales. En este modelo, hay un doble rol del Estado como promotor del desarrollo de esa burguesía "con conciencia nacional", y como defensor de la clase trabajadora que es empleada de aquella.

\subsection{Frente Popular Darío Santillán}

a. Estado y política institucional.

Hay ya en los apartados anteriores algunas consideraciones sobre la lógica desde la que la organización concibe al Estado, al gobierno y a los mecanismos de la política institucional. Cuando veíamos las reflexiones sobre la desaparición de Julio López aparecía una visión en la que el Estado no es ese ente omnipotente y omnipresente que aparece en otros discursos. Hay en el Estado debilidades y contradicciones, y no se lo identifica con el gobierno, esto es, al aparato con sus dirigentes responsables temporales.

En el mismo sentido el Estado no es el representante necesario de los intereses de las clases dominantes, sino que desde allí se pueden desarrollar procesos políticos articulados con los sectores populares, como es la visión que aparece respecto a los gobiernos de Venezuela y Bolivia. 
Respecto a la relación específica de la organización con el Estado, éste aparece principalmente como un proveedor de recursos (planes, subsidios, mercaderías), lo que pone a la organización en el desafío de resignificar esos recursos y a la vez evitar cualquier tipo de condicionamiento político en resguardo de su autonomía:

En la práctica el Estado a estado siempre presente en la experiencia nuestra. Porque conseguimos los planes del Estado, la mercadería del Estado, sostenemos proyectos productivos que se originan como consecuencia de subsidios estatales. El Estado está siempre presente en la construcción política que nos damos. (...)Tomamos recursos del Estado, siempre que consideremos que somos capaces de resignificar esos recursos y de que no vamos a estar condicionados políticamente. (Obregón, 2006)

Sobre los mecanismos de la política institucional, no hay una definición a priori o esencial, por ejemplo con la opción electoral como escenario de participación. Señalan que se debate en función del contexto la posibilidad o no de participar en ese espacio y que desde el 2003 en adelante mantuvieron una posición abstencionista a partir de diagnosticar las escasas o nulas posibilidades con las que contaban en tal terreno.

Por último, en su discurso político no aparece el Estado como un espacio a conquistar, como un objetivo político central. Aquí se acercan a visiones más autonomistas o situacionales, argumentando que, a partir las "experiencias históricas en las cuales se ha tomado el poder del estado y la cosa por abajo no ha cambiado nada" privilegian la construcción de poder popular "que no es ni más ni menos que el hecho de ir generando niveles organizativos cada vez más altos a nivel de los sectores populares que puedan en algún momento disputar poder".(Obregón, 2006)

b. Clase y lucha de clases.

Cuando analizábamos la autodefinición ideológica de la organización aparecían algunos elementos de la concepción de clase social de la que parte la organización. El sujeto político al que ellos apelan es el pueblo o el pueblo trabajador en tanto parten de considerar que el capitalismo ha generado en las últimas décadas "nuevas formas de vinculación con la explotación capitalista" (FPDS, 2007) y que por tanto la clásica categoría de clase obrera ha perdido precisión y utilidad desde el punto de vista político.

Este sujeto ya no puede limitarse a la clase obrera ocupada formalmente, sino que abarca a un conjunto de sectores sociales que son víctimas directas o indirectas del capitalismo y que solo pueden realizarse como tales en tanto protagonicen cambios revolucionarios, por lo que decimos que el sujeto es plural o multisectorial, y lo denominamos como pueblo trabajador, o como pueblo. (FPDS, 2006) 
Del mismo modo destacan la centralidad y la autonomía de la política respecto de "lo social", buscando apartarse de miradas esencialistas que atribuyen un contenido político a condiciones sociales. Así señalan: "Valoramos a la conciencia política y a la conciencia de clase como procesos, y no como objetos que se introducen artificialmente desde afuera por intelectuales esclarecidos." (FPDS, 2007)

Por todo esto entendemos que la cuestión de clase se concibe de un modo heterodoxo, apartado de las visiones más tradicionales y clásicas, incorporando diversos actores -como sujetos políticos- que van más allá de la clase obrera. Si bien destacan que no hay un sujeto preestablecido que encabece el proceso de transformación social, también aclaran que "este reconocimiento de la pluralidad del sujeto no atribuye a todos los sectores el mismo peso estratégico" ya que se reconocen "potencialidades diferentes de acuerdo al lugar que ocupan en la producción, sus posibilidades de acumular triunfos y organizarse, desde sus dimensiones cuantitativas y desde su experiencia de lucha”. (FPDS, 2007) Más allá de esto no hay más precisiones al respecto y resulta ilustrativa de esta heterodoxia la consideración del peronismo "como experiencia de lucha de clases".

\title{
c. La cuestión nacional
}

La apelación a lo nacional no constituye un lugar importante ni estratégico en el discurso de la organización. Sí es tenido en cuenta como marco de construcción, esto es, el FPDS busca ser una organización que se desarrolle a nivel nacional, pero no aparece como un eje convocante. Esto nos trasmitía Obregón cuando lo consultábamos sobre el lugar de la "cuestión nacional" en el discurso del FPDS:

\begin{abstract}
En las discusiones teóricas, nosotros no discutimos específicamente la "cuestión nacional". Evidentemente, sí la nación es el escenario en el que pensamos la política. Incluso todo el tiempo hablábamos de nacionalizar La Verón, hablamos ahora nacionalizar el Frente. Nos interesa muchísimo que se formen organizaciones o coordinaciones en distintos lugares del país. Por ahí alguien dice: "tengo una punta en San Luis", y ya te brillan los ojos. Está presente, pensamos en escala nacional el proyecto. (Obregón, 2006)
\end{abstract}

Desde su punto de vista la "no centralidad" de la cuestión nacional obedece por un lado a que la composición del frente es resultado de la articulación de corrientes político ideológicas diferentes y en ese sentido se diluye en el conjunto de líneas que conviven en el discurso ideológico de la organización. Por otro lado, también se menciona una cuestión temporal, generacional, según la cual en la actualidad lo nacional no tendría las cualidades convocantes de otras épocas. De todos modos no se cierra la posibilidad y utilidad de su uso, aunque claramente no tiene la relevancia que tiene en otros discursos, como por ejemplo en el del MUP. 
Tal vez en otros momentos históricos, la identidad nacional era un tema muy fuerte. En nosotros eso está diluido y matizado por la cantidad de corrientes que forman el Frente. Si nos parece que puede ser un eje convocante y que te puede ayudar a sumar. Yo te mencionaba el tema de los recursos naturales, eso está muy ligado a la cuestión nacional, también a la cuestión latinoamericana. No son excluyentes.(Obregón, 2006)

\title{
7.5. MPR-Quebracho
}

a. Estado y política institucional.

En consonancia con la matriz nacional-popular, el Estado aparece en el discurso de la organización con gran centralidad, no sólo como espacio de poder que debe ser conquistado, sino también como promotor del cambio social que se pretende llevar adelante.

\begin{abstract}
P:¿Qué lugar ocupa el Estado, que lugar ocupa la política institucional?

R: Hay dos cosas. Una es la conceptualización que pudiéramos hacer y yo te dijera que nos parece el Estado desde el punto de vista ideológico. El problema es que nosotros hacemos política, nosotros creemos que la única manera de resolver el problema de los argentinos es con el control del aparato del Estado. De un Estado mucho más poderoso que este. Mucho más fuerte, mucho más presente. Que los recursos estratégicos que puedan construir la autonomía, la independencia económica de un país, los tenemos que recuperar y tienen que estar en manos del Estado. El poder del Estado hay que conquistarlo. Hay que acceder al gobierno y hay que disputar el poder, que son dos cosas distintas. $Y$ creo que la única manera de articular una sociedad integrada, el único que tiene posibilidad de lograrlo es el Estado. Todo lo demás, las ONG's y todas esas cosas, lo que hacen es lo contrario. Es más disgregación social. (Esteche, 2007)
\end{abstract}

A diferencia de discursos marxistas más clásicos, no hay una esencialización sobre la imbricación necesaria del Estado burgués con los intereses de los sectores económicos dominantes. Sí se identifican a los últimos gobiernos -de 1976 a esta parte- como representantes de esos intereses, pero no aparece como un rasgo inherente del Estado, y se contempla la posibilidad de que el Estado Burgués, en manos de gobiernos populares puedan llevar adelante los cambios sociales necesarios, los que a su vez implican la transformación del propio Estado. Los ejemplos históricos sobre los que se apoyan estas ideas son las experiencias de Perón en nuestro país, y los casos actuales de Chávez, Morales y Correa.

Respecto a los mecanismos de la política institucional no hay definiciones cerradas o a priori. Se habla de la posibilidad de participar en elecciones siempre y cuando el momento así lo indique:

Una de las definiciones políticas más importantes que nos caracterizan es que desde que nacimos jamás hemos participado en las elecciones. Nuestra conducta en este aspecto no tiene que ver con una definición absoluta, sino con una cuestión estrictamente práctica. Si en determinada situación entendiéramos que nuestra participación en las 
elecciones es conveniente para la causa popular, participaríamos."

(Rubio y Del Grosso, 2005:20)

En líneas generales se puede percibir cierto desprecio por los mecanismos institucionales de participación democrática existentes en nuestro país, que se refleja en la centralidad que tienen las propias acciones directas y en el no reconocimiento de la -al menos relativa- legitimidad que pudieran tener las autoridades elegidas en los procesos electorales. Del mismo modo, la no participación en dichos procesos obedece a una cuestión de conveniencia política, de posibilidades concretas y reales, más allá de la legitimidad intrínseca con la que pueden contar los procesos eleccionarios en relación a otras prácticas y medios políticos. En última instancia, y más allá de la posibilidad de participar en la arena electoral, sostienen que "es profundizando el camino de la rebelión popular que iremos acumulando y generando las condiciones para la victoria revolucionaria”. (Rubio y Del Grosso, 2005:20)

b. Clase y lucha de clases.

Si bien el MPR-QB plantea una lucha patriótica que concibe como objetivo último el socialismo, no hay una apelación estrictamente clasista de los sujetos políticos que llevarán adelante el proceso político de transformación. En este sentido señalan:

"Si hablamos de una revolución democrática, antiimperialista, y por el socialismo estamos hablando de construir un bloque social revolucionario que integre a todos los sectores que objetivamente están enfrentados con el imperialismo: la pequeña y mediana industria, los sectores medios, los sectores estudiantiles, los sectores del campo (los que laburan el campo, no los grandes terratenientes), los trabajadores ocupados y desocupados. Obviamente que la columna vertebral de cualquier bloque social revolucionario tiene que ser la clase obrera". (Shinzato y Zanzioth, 2007:196)

Es decir, se repite el esquema frentista que aparece en otros discursos, desde un lugar amplio y contingente, flexibilizando el modelo estrictamente clasista tan caro al marxismo-leninismo. Sin embargo, el espacio que abre esta perspectiva para el juego de significantes vacíos y lógicas equivalenciales parece reducirse a partir de la centralidad que adquiere la lógica insurreccionalista, que se transforma en un elemento (¿casi?) innegociable y que se apoya, a su vez, en una lógica antagónica schmitteana ${ }^{84}$ en la que las opciones parecen reducirse a la eliminación del enemigo político.

\section{c. La cuestión nacional}

\footnotetext{
${ }^{84}$ Hacia el final del capítulo profundizaremos esta cuestión. Para una aproximación al planteo ver Mouffe (2007), En torno a lo político.
} 
Como vimos en diferentes pasajes del análisis del discurso de esta organización, la cuestión nacional tiene una gran centralidad. La apelación a la Patria es un tópico recurrente en la presentación identitaria de la formación política. La "lucha por la liberación latinoamericana" aparece condensando los objetivos principales de la organización. Veíamos que distinguían entre la Patria y la Nación, optando por la primera en tanto no reduce la disputa política a las fronteras del Estado-Nación, sino que remite a la vez a la lucha continental en contra del imperialismo, enemigo común de los países vecinos.

"Si hoy padecemos dependencia debe ser un programa de liberación; si este modelo se sostiene con apertura e integración de mercados, entonces debe proponer protección a la industria nacional." (Rubio y Del Grosso, 2005:30)

De esta manera vemos en el discurso la aparición de la disyuntiva entre liberalismo económico y proteccionismo, ausente en otras organizaciones en las que las alternativas son las de capitalismo vs. socialismo. Podemos señalar que el MPRQB busca, al igual que otras formaciones, conjugar la lucha nacional (patriótica) antiimperialista con una lucha clasista que termine otorgándole a la clase obrera un lugar central privilegiado. El modo en que se articulan ambas dimensiones es una cuestión que atraviesa a casi todas las organizaciones que observamos. En el caso del MPR-QB los componentes nacional-populares se entrelazan con una fuerte lógica insurreccionalista que la constituye en una singular combinación que le otorga un rol significativo a la burguesía nacional -y sectores medios- pero a la vez plantea un modo de construcción -más comunes en organizaciones marxistas-leninistas- que pareciera dificultar la adhesión de esos sectores.

\subsection{MTD - Aníbal Verón}

a. Estado y política institucional.

En este punto aparecen definiciones precisas que permiten establecer algunas distinciones que resultan significativas para nuestro trabajo. En particular hay una mención sobre un cambio de concepción desde una perspectiva marxista clásica hasta una visión más heterodoxa a la luz de las experiencias políticas de Venezuela y de Bolivia, casos en los que no se produce la "destrucción del estado burgués" sino que se ocupa y desde allí se acumula hacia el socialismo. Citamos a continuación un fragmento donde aparece con claridad la postura del entrevistado.

Durante muchos años en lo que fue nuestra práctica vemos el Estado, como definición teórica, como el instrumento de dominación de las clases dominantes, de hecho el Estado por definición siempre ha sido eso, desde la ideología que uno tiene. Si me pongo forro y ortodoxo, la junta administrativa de los negocios de la burguesía, ja. Los gerenciadores... (...) Ahora, vemos procesos como los que se están 
dando en América Latina que a nosotros nos pegan en la piedra angular del debate sobre ese Estado. Porque desde la concepción clásica, desde la concepción general de la izquierda, toda la lucha, sea popular y prolongada, sea insurreccional, sea lo que fuere, es de acumular en una especie de guerra, de lucha de masas o de lo que carajo fuere, acumular en una continua lucha de destrucción del Estado. Y sobre las cenizas de ese Estado destruido, lo cual presupone -o debería presuponer un determinado nivel de conciencia de las masas- construir un Estado socialista. El proceso que se está dando con Chávez, con Evo Morales, te dice otra cosa. Te habla del Estado burgués como un elemento de acumulación, en ese sentido hacia el socialismo. $Y$ francamente ese es un debate que nosotros tenemos. $Y$ que es un debate interesante que vale la pena saldarlo. Después que nos dé el cuero o no, es otra historia. (Daffunchio, 2007)

Como decíamos, aparece un interesante relato del modo en que cambia la manera de concebir al Estado, con las consecuencias políticas directas que acarrea. Es un caso interesante que manifiesta una adecuación de la teoría a los datos de la experiencia, de lo que se interpreta de la realidad. Estamos tentados a señalar, que en muchos casos el proceso de adecuación suele funcionar en sentido inverso.

En un registro similar, se sugiere la idea de un estado intermedio, que tenga una fuerte presencia en el mercado, pero que no lo contenga completamente, "un Estado intermedio donde haya un equilibrio entre lo privado y lo público" (Daffunchio, 2007).

Por otro lado, también se destaca la presencia de limitaciones y contradicciones presentes en todo aparato administrativo estatal, en especial en lo que refiere al caso argentino. Desde esta perspectiva se establece una clara distancia con las posturas que tienden a resaltar la casi absoluta capacidad de control e ingerencia que detenta el Estado, lo que denominamos hasta acá concepciones de Estado omnipotente.

Por último hay una clara valoración positiva sobre el sistema democrático, más allá de las limitaciones que no desconoce, pero que en última instancia constituye un avance respecto a regímenes políticos totalitarios. ${ }^{85}$ Esta cuestión no está presente, al menos de esta manera, en otros discursos que identifican fuertemente el régimen democrático como burgués, como una herramienta de dominación política pergeñada por las clases dominantes económicas, y por tanto es descalificado sin demasiados matices.

b. Clase y lucha de clases.

\footnotetext{
${ }^{85}$ En relación al "Caso López" señala: "Pero acá por lo de López tendríamos que haber hecho movilizaciones masivas, ni en contra ni a favor del gobierno... Incluso en defensa de la democracia. Porque si uno pone a la dictadura y a esos hijos de puta y a esta democracia burguesa, yo prefiero esta democracia burguesa. Después veremos como hacemos para cambiar esta democracia burguesa, pero esa dictadura, no.", (Daffunchio, 2007)
} 
La cuestión de la clase y de la lucha de clases está presente en el discurso de Daffunchio dando cuenta de su formación guevarista. Si bien aparecen fuertes críticas al dogmatismo de la izquierda, esto no implica el abandono de una perspectiva clasista en el análisis político y sociológico. A esta altura podríamos identificar la presencia del conflicto de clases como uno de los rasgos más claros y distintivos del conglomerado campo popular, esto es el reconocimiento de que la sociedad está atravesada por un conflicto estructural de raíz económica que establece una división entre una minoría privilegiada y una mayoría desfavorecida.

Es partiendo de este diagnóstico común que surgen las diferencias sobre qué características posee este enfrentamiento, y especialmente, qué tipo de estrategias políticas son las más efectivas para modificar los componentes más sobresalientes de la desigualdad social. En el discurso de Daffunchio hay una mención reiterada a la clase, a la pertenencia de clase y a la lucha de clases, pero estas menciones se inscriben en la postura ya señalada que privilegia la apertura, la heterodoxia y que combate los dogmatismos. En este sentido aparece el 17 de octubre como una "jornada clasista", y a la vez señala, respecto al secuestro de López, que "demuestra que en la Argentina todavía esas mafias, que fueron las triunfadores de una lucha de. clases durante la dictadura militar, existen y tienen poder." (Daffunchio, 2007)

\section{c. La cuestión nacional}

En consonancia con la postura que venimos observando en el discurso de Daffunchio, nuevamente aparece una fuerte autocrítica, esta vez vinculada con la deficiencia de las organizaciones de izquierda que no priorizan el estudio de la realidad y la historia argentina. Así lo señala:

\section{P: La cuestión nacional ¿Qué lugar ocupa, de qué manera? ¿Figura en algún lugar? \\ $R$ : Como autocrítica. Porque nosotros provenimos de una izquierda que aprendió de todo menos historia argentina. La izquierda conoce más de la revolución cubana, de la china, de Vietnam y de la rusa que de Argentina. Ese es otro de los grandes problemas, y para nosotros un desafío. No podemos hacer cambios en este país, empujar hacia el socialismo a este país, si no comprendés tu propia historia. En realidad debería ser una cosa simple, pero se tarda y se paga con derrotas, con años de sacrificio, de militancia y con discusiones, entender esto. (Daffunchio, 2007)}

La cita es clara y contundente en el señalamiento sobre el déficit de su propia formación y el de la izquierda en general sobre lo nacional, sobre el estudio y conocimiento de la historia nacional y por tanto, de las dificultades que se derivan de allí para un conocimiento cabal de la realidad del país. Esta crítica que es conocida 
desde los primeros exponentes de la izquierda nacional ${ }^{86}$ resulta más llamativa cuando forma parte de una autocrítica concreta como en este caso.

\subsection{Movimiento Teresa Rodríguez}

a. Estado y política institucional.

La cuestión del rol y las características del Estado es un tema que viene apareciendo con fuerza a lo largo de todo el discurso de la organización. Esta presencia remite al debate sobre reforma y revolución que atraviesa todo su planteamiento político. Como ya lo pudimos observar en apartados anteriores, el Estado es concebido como "una maquinaria que diseña una clase para dominar a la otra. Por lo tanto esa maquinaria como tal no puede servir a la clase dominada para perseguir sus objetivos. Tiene que destruir esa maquinaria y construir otra." A partir de esta concepción, la revolución social "no significa disputar Estado. Significa abolir el Estado actual y construir un Estado nuevo." (Martino, 2007)

Las definiciones en este punto son claras. El Estado no debe ser disputado en el sentido de creer que desde allí, desde esas estructuras, se pueden lograr transformaciones sustanciales, "considerar que se puede eliminar la tremenda desigualdad social, el analfabetismo, el hambre (...) a través de las actuales instituciones, es sin duda, equivocarse profundamente". (Todo o Nada, 2006)

Respecto a la política institucional no hay una definición a priori sobre participar o no en contiendas contenidas dentro de los marcos institucionales. No se descarta la opción de participar electoralmente a través de la conformación de un frente político con cierta proyección. En definitiva está sujeto a las circunstancias del momento y a la lectura que de ellas se haga. Está posición, materializada en un intento de conformación de un frente político electoral con figuras como Luis Zamora y Hebe de Bonafini, llevó a que sectores de la organización abandonaran la misma, acusando a los partidarios de esta postura -justamente- de reformistas.

Sin dudas el criterio de mayor relevancia es el de la concepción respecto del Estado y las consecuencias que ella trae consigo. Se señala que "esta es una de las grandes diferencias, de los grandes problemas que tenemos todavía en el campo popular" (Martino, 2007), es decir que opera como un claro delimitador del espacio político estableciendo lógicas equivalenciales y diferenciales de gran relevancia para pensar el tema de la articulación política. Los límites para establecer hasta donde se trata de reformismo o de revolución, sin dudas están sujetos a las propias valoraciones e interpretaciones de los sujetos y nos llevan a operaciones discursivas y distintos

\footnotetext{
${ }^{86}$ Para un recorrido por los debates que dan nacimiento a la llamada Izquierda Nacional, ver Norberto Galasso (2007).
} 
niveles de fijación de significado en torno a esas categorías, tema que nos interesa en este trabajo. En este caso vemos que hay definiciones rígidas sobre la concepción de la revolución, en donde la destrucción del Estado aparece como un paso ineludible. Lo que no se resuelve, son las formas, posibilidades, características y demás elementos que disminuyan la brutal abstracción sobre la abolición del Estado. Es decir la fijación de significado en el concepto de revolución remite a un concepto -el de abolición del Estado- que es planteado en términos teóricos que denotan una gran abstracción o, en el mejor de los casos, asociado a experiencias históricas -la más común es la de la Revolución Rusa- que, por lejanas y disímiles poco aportan al esclarecimiento y a la precisión de las definiciones que se discuten.

b. Clase y lucha de clases.

La clase y la lucha de clases es una cuestión infaltable en el discurso de toda organización se define al interior de la matriz marxista-leninista. La idea de revolución social que se sugiere implica un enfrentamiento claro y directo entre capitalistas y clase trabajadora. Cuando Martino nos hablaba del origen de la organización, hacía especial hincapié en destacar que ellos vieron en los desocupados un sector dinámico de la clase trabajadora, pero que su objetivo excedía lo meramente reivindicativo de ese sector y que apuntaba al fortalecimiento político de la clase trabajadora en su conjunto, el sujeto privilegiado para la estrategia política.

Si bien no hubo definiciones precisas y explícitas sobre esta cuestión, sí se desprenden algunas definiciones significativas de diversas proposiciones del discurso. Un ejemplo lo veíamos en la crítica de Martino a Chávez cuando decía "yo lo veo como líder nacionalista, populista. Populista en el sentido que no tiene la visión clasista". Aquí la apelación al pueblo en detrimento de la clase, es vista como un claro defecto. En el mismo sentido aparece la crítica, ahora en términos generales, a las dirigencias políticas de los países latinoamericanos: "El problema es que las direcciones políticas, el carácter reformista... el carácter no proletario -diría yo- los coloca en una encrucijada" (Martino, 2007) en donde lo reformista aparece como la contracara de lo proletario, y lo revolucionario es necesariamente proletario. La dilución o matización del enfrentamiento entre clases es un punto destacado de la crítica a los procesos políticos de Venezuela y Bolivia.

\section{c. La cuestión nacional}

La cuestión nacional no tiene una presencia significativa en el discurso identitario de Martino, en tanto aparece apenas mencionada como una posibilidad para "tender puentes" hacia sectores nacionalistas que defienden ciertos tópicos de 
soberanía de recursos etc. Sin embargo estos puentes aparecen cortados de antemano porque aquellos sectores nacionalistas aparecen asociados a la búsqueda de un capitalismo "más desarrollado, más humano", por tanto no están con el socialismo y eso, para Martino, se constituye en una diferencia insalvable.

\section{P: ¿Que lugar ocupa la cuestión nacional dentro de la perspectiva de la organización? \\ $R$ : Nosotros creemos que hay un sector del nacionalismo que va a jugar} de aliado en el proceso revolucionario. Por eso hay que darse una tarea de tender puentes. De hecho, digamos, los que más han hecho por la recuperación de YPF, ha sido el Grupo Moreno. Ningún partido de izquierda. Nosotros apoyamos eso. Entonces, ese sector, expresa cierta parcialidad de la pequeña y mediana burguesía argentina que tiene grandes contradicciones con el peronismo, con el proceso de concentración. Bueno esos son los sectores que deben jugar de este lado. El problema que hay es que esos sectores lo que intentan es establecer un capitalismo más desarrollado, más humano. Hasta ahí llegan. Eso requiere que haya una construcción que realmente pueda llevar un proceso a un buen puerto. Cuando hablamos de marxismo, de guevarismo, nosotros adherimos totalmente a lo que plantea Guevara de que en las condiciones de América Latina, si la revolución no es socialista, no tiene ninguna perspectiva. No puede haber un desarrollo de las fuerzas productivas de la nación, si no es bajo un planteo socialista. El capitalismo no va más. (Martino, 2007)

A partir de definiciones que se presentan un tanto rígidas ("si la revolución no es socialista no tiene ninguna perspectiva" o "no puede haber desarrollo de las fuerzas productivas de la nación si no es bajo un planteo socialista") el discurso de Martino se circunscribe a la matriz marxista-leninista subordinando drásticamente cualquier otro conflicto o antagonismo social a la lucha de la clases y a la revolución socialista. De esta manera, el camino hacia un "capitalismo más desarrollado, más humano", no merece demasiada consideración ni valoración, en tanto no hay alternativa al socialismo. Pareciera operar el sentido del título de su publicación; el planteo es: "Todo o Nada".

\subsection{Barrios de Pie (Libres del Sur)}

a. Estado y política institucional.

El Estado aparece en el discurso de la organización como un espacio en disputa, un factor de poder, una herramienta que resulta fundamental para avanzar en procesos de transformación. Se está lejos de las visiones más clásicas del marxismo en donde es visto como una herramienta inherentemente ligada a los intereses de determinada clase social. Lo político aparece así condicionado y atravesado por lo económico, pero no determinado, con grados de autonomía y especificidades propias.

Así lo expresaba Baigorria:

El Estado es un factor de poder para nosotros. Es un factor de poder que en la democracia que tenemos, llamale burguesa, es un factor de 
poder que es disputable. Desde nuestro punto de vista es un factor de poder, una herramienta, que hay que traerlo para este lado, no para el otro lado. No prescindir de él. Tampoco podés estar en el Estado para mimetizarse con el Estado y después ya lo que estás haciendo no contribuya más a la transformación o a la reproducción de la misma cuestión. Igualmente el Estado es un espacio muy importante. El Estado tiene muchos niveles, mucho más grande que lo que se cree por fuera. (Baigorria, 2007)

Desde esta concepción, el Estado es la herramienta necesaria para llevar adelante las transformaciones, no aquel espacio que debe ser destruido, sino modificado y reorientado hacia nuevo intereses. En este sentido se habla de la necesidad de contar con un "Estado empresario" e interventor (con fuerte injerencia en la orientación económica), de nacionalizar recursos estratégicos como el petróleo y el gas, de avanzar en una profunda reforma impositiva progresiva y redistributiva, de desarrollar una reforma política con democracia participativa y de consolidar una reforma de la Constitución Nacional que contemple la principales demandas de la mayorías. Del mismo modo, se aleja de la concepción del Estado como entidad omnipotente y omnipresente, en tanto se desataca su amplitud, su vastedad, sus diferentes niveles, sus contradicciones, en suma, su complejidad y limitaciones.

Respecto a la política institucional se destaca su relevancia e importancia como dimensión de disputa de poder, como espacio de representación de la sociedad. Más arriba veíamos que se hacía especial mención de la centralidad de aquella dimensión junto con la capacidad organizativa y de movilización, como indicadores reales de la fortaleza política de cada actor. La política institucional forma parte de "las reglas del juego" y no aparece "otra cancha como viable".

Es fundamental disputar el Estado. Dentro de esa disputa del Estado, está la disputa electoral. La disputa electoral para nosotros es central en la disputa política. Acá no alcanza con tener la gente en la calle, vos tenés que disputar la representación de la gente en términos generales para poder rumbear y profundizar los cambios. (...) Vos podés hacer muchos piquetes, el problema es si eso te aísla o te acerca al conjunto de la población que vos te querés acercar. (Baigorria, 2007)

b. Clase y lucha de clases.

En coincidencia con los principales rasgos que se deducen de la matriz nacional-popular, no hay una concepción de lucha de clases en términos marxistas clásicos, como una contradicción irresoluble sin la eliminación de una de las partes. En el esquema de la organización, es viable avanzar en un proceso de transformación mediante una construcción política de alianza de clases que contenga "desde las mayorías populares de trabajadores, pobres de la ciudad y el campo y clases medias, hasta el propio empresariado nacional." (LS, 2008) 
Esto no niega la existencia del conflicto entre clases sociales, sólo plantea la posibilidad de que se puedan desarrollar experiencias políticas que contengan los intereses nacionales y populares en beneficio de las mayorías hacia una sociedad en la prevalezca la "justicia social". Para esto resulta imprescindible que los sectores populares junto a sectores del empresariado nacional avancen en detrimento de la fuerza política de los sectores concentrados de la economía, en donde el conflicto se plantea más en términos de la posibilidad de imponerse y domesticar a dichos sectores, antes que de su eliminación. A diferencia del contexto en el que se desarrolló la experiencia del peronismo, hoy aparece una "contradicción mayor entre el empresariado nacional (o por lo menos la parte dominante del mismo) y las clases populares", ya que la economía actual no tiene como desafío la "sustitución de importaciones", sino que "ahora la locomotora deben ser las exportaciones, y tenemos una parte no desdeñable de las mismas en manos de grandes grupos económicos locales e internacionales." (LS, 2008)

De esta manera, el discurso de la organización se basa en un esquema de lucha de clases, pero que es posible dar dentro de marcos institucionales a partir del cambio en la correlación de fuerzas políticas, construyendo una fuerza nacional y popular que represente los intereses de las clases populares. No hay una identificación de un sujeto privilegiado para la acción política a partir de sus rasgos socioeconómicos, en todo caso lo que se plantea es la necesidad de una construcción política -que no está predeterminada en términos de clase- que busque representar los intereses de las mayorías; esto es, que promueva un modelo de país con inclusión y justicia social, en contra de la exclusión y la desigualdad.

\section{La cuestión nacional}

No nos explayaremos demasiado en este punto ya que vinimos analizando está cuestión en esta organización en varios de los apartados anteriores. Pudimos ver que la "cuestión nacional" se presenta como un punto de distinción respecto a la "izquierda tradicional" y es entendida como "el paso previo a consolidar un país con un determinado grado de desarrollo, que permita sobre esa base material objetiva, avanzar a la construcción de una sociedad de otro tipo" (Baigorria, 2007)

De este modo, el tema de lo nacional aparece delimitando fuertemente el espacio político con claras consecuencias respecto a la articulación política. Así vimos como Baigorria señalaba que al interior del "movimiento piquetero", la "salida por lo nacional" no aparecía como una opción posible, lo que derivaba en la primacía de diagnósticos prerrevolucionarios sobre la coyuntura del 2001 y, acorde con ello, en 
estrategias políticas insurreccionalistas que se alejaban del diagnóstico que tenía la organización.

La valoración y centralidad que adquiere la "cuestión nacional" en el discurso de la organización lleva a la organización a una identificación mayor con las organizaciones de matriz nacional-popular y a su acompañamiento -aunque, como vimos precario y sujeto a la contingencia- respecto del kirchnerismo.

\subsection{Múltiples dimensiones, múltiples agrupamientos}

Tres matrices, tres Estados: Lo rompo, lo uso o lo dejo

Las diferentes perspectivas que apretadamente resumimos en estas líneas buscan reavivar el debate sobre las consideraciones respecto del Estado y sus correlatos en el terreno de la acción política. Uno de los debates que subyace a las distintas valoraciones que aquí vimos tiene que ver, ni más ni menos, con la capacidad para explicar, comprender y poder actuar sobre el universo social.

El paradigma marxista-leninista da una respuesta acabada a muchos de los interrogantes que alguien pueda plantearse respecto a los mecanismos de dominación social y a las estrategias políticas de transformación. Quizás sea, justamente, que se trata de respuestas acabadas lo que le quita cierta flexibilidad a su esquema de análisis político. La prioridad ontológica de lo económico y la identificación de una contradicción fundamental al interior del cuerpo social -capital vs. trabajo- se reviste en el marxismo-leninismo de una pretensión explicativa de carácter exhaustivo. Todo puede ser explicado en última instancia al interior de aquellas grandes coordenadas, lo que pareciera conducir a desatender otros elementos explicativos -otras dimensionesque complejizan la visión del universo social.

Al interior de este esquema las alternativas políticas se reducen a la necesidad de la revolución, es decir, a la abolición del Estado. El esquema binario capital vs. trabajo se reproduce infinitamente absorbiendo las graduaciones y matices incluyendo los diversos niveles y contradicciones del aparato estatal- que pudieran observarse. Los diversos actores sociales y políticos se identifican con uno u otro bando. Si no se está con la Revolución se está en contra de ella. El Estado, por ser gerente omnipotente y omnipresente de los intereses de la burguesía, se constituye en el enemigo primero y último que debe ser combatido y destruido.

La matriz nacional-popular se aleja de la identificación necesaria del Estado con las clases capitalistas. El universo político no aparece preconstituido por las características que provienen de la dimensión económica. De esta manera se trata de resaltar la autonomía de la esfera de lo político en oposición a cierto economicismo que se hace probable al interior del esquema de análisis marxista. Así se destacan 
múltiples actores, intereses y contradicciones que en otros esquemas resultan desatendidos por considerarlos irrelevantes.

El proceso de transformación es planteado en términos más graduales, lo que parece implicar, a su vez, una mayor graduación del mapa de actores políticos. Entre la contradicción campo popular vs. campo liberal proliferan múltiples actores con intereses particulares que flexibilizan el esquema de alianzas políticas. Las dificultades en este sentido son las de que se caiga en un pragmatismo político que pierda de vista los intereses que subyacen al ámbito político.

La izquierda heterodoxa busca proponer alternativas a los esquemas más tradicionales. En este sentido se relativizan ciertas proposiciones que se consideran demasiado rígidas o superadas. El Estado no es el brazo administrativo de la burguesía, pero tampoco es la herramienta imparcial que puede ser usada fácilmente para los fines del gobierno de turno. Las opciones de construcción política quedan abiertas al desarrollo de los acontecimientos, pero subsiste un recelo -mucho más en el FPDS que en el MTD-AV- para mantenerse distante de las esferas de la política institucional. Lógicamente, el peligro de este esquema es que, por evitar las contradicciones y falencias inherentes a las estructuras e instituciones del escenario político, se pierda en eficacia política y capacidad de transformación.

\section{En búsqueda del sujeto político}

Como señalábamos anteriormente, cada una de las organizaciones que estudiamos incluye en su análisis político la identificación de clases sociales dominantes y clases subalternas y el conflicto entre ellas. Sin embargo, cada una establece posiciones diferentes cuando precisan las características de esas clases, su aparición en la escena política y el modo en se desarrolla el conflicto entre ambos bloques. En el cuadro que sigue, buscamos establecer tres ejes de comparación para profundizar nuestro análisis. En primer lugar está el modo en que se concibe la relación entre la clase social y su representante político; la relación entre clase y partido. En la segunda columna se busca observar el grado de restricción que deriva de las diversas definiciones de clase que se observan. Finalmente, en la tercera columna se compara el modo en que se presenta la disputa entre las clases y entre sus representantes políticos.

\begin{tabular}{|cc|c|c|} 
& $\begin{array}{c}\text { Equivalencia } \\
\text { clase/partido }\end{array}$ & $\begin{array}{c}\text { Clase } \\
\text { restringida }\end{array}$ & $\begin{array}{c}\text { Criterio amigo/enemigo } \\
\text { (enfoque antagonista) }\end{array}$ \\
PO & SI & SI & SI \\
CCC-PCR & SI & NO & SI \\
MUP & NO & NO & NO \\
FPDS & NO & NO & NO \\
MPR-QB & NO & NO & SI \\
MTD-AV & NO & NO & NO \\
\hline
\end{tabular}




\begin{tabular}{|c|c|c|c|}
\hline MTR & SI & SI & SI \\
MBP & NO & NO & NO \\
\hline
\end{tabular}

Haremos una lectura vertical del cuadro para comparar cada una de las dimensiones en cuestión. Tanto en el PO, en el MTR como en la CCC-PCR, es decir en las organizaciones declaradas puramente ${ }^{87}$ marxistas-leninistas, encontramos una fuerte identificación entre la organización -o el partido- y la clase social que busca ser representada. A diferencia de las otras, en cada una de estas organizaciones se plantea de modo literal la representación de los intereses de la clase proletaria o trabajadora. De esta manera se destaca la presencia de un sujeto político privilegiado -"el único capaz"- que se presenta preconstituido desde la esfera socioeconómica. Del mismo modo se supone la existencia de intereses objetivos que dicha clase posee en función de su "ubicación estructural", los que son fielmente interpretados y representados por las organizaciones y partidos en cuestión.

La segunda dimensión comparativa refiere a otro clásico debate sobre los alcances de lo que se denomina el proletariado o clase trabajadora. Las posturas al respecto varían incorporando más o menos sectores del mundo laboral y hasta, en algunos, empresarial (profesionales, cuentapropistas, pequeña y mediana empresa, sectores medios en general). Según este criterio, identificamos al PO y al MTR mucho más claro en el primero que en el segundo- como aquellas organizaciones en las que la apelación a la clase trabajadora se hace de modo más restringido, clausurando de antemano la posibilidad de establecer lógicas equivalenciales con otros actores, en tanto se considera que no pertenecen a aquella. Cual exclusivo Club Privado, las normas de admisión se tornan particularmente estrictas.

Finalmente, nos interesaba comparar el modo en que se concibe el enfrentamiento entre las clases sociales -y sus representantes políticos- y para ello apelaremos a la distinción que hiciera Chantal Mouffe (2007) respecto a los enfoques antagonista y adversarial o agonista. De acuerdo a esta autora, el enfoque antagonista (schmitiano) es aquel que plantea la diferencia política en términos de amigo-enemigo, lo que deriva en concepciones de la política en las que el enemigo debe ser eliminado, en tanto no se acepta ni se legitima un terreno que permita la resolución de los antagonismos de otro modo. ${ }^{88}$ Esto implica que los espacios para mediaciones y

\footnotetext{
${ }^{87}$ Decimos puramente en referencia al caso del MPR-QB que, como ya señalamos, se declaran marxistas leninistas, pero a la vez nacional-populares.

${ }^{88}$ La identificación de estos enfoques se entrelaza con la distinción entre el terreno de lo político (lo ontológico) y la política (lo óntico, su forma de aparición) que mencionábamos más arriba. En este sentido, el enfoque agonista, no pretende desconocer la presencia del antagonismo como elemento constitutivo de lo político -como lo haría el enfoque liberal-, sino que lo circunscribe a una forma de aparición -la política- adversarial. Desde esta perspectiva, "la dimensión antagónica está siempre presente, es una confrontación real, pero que se desarrolla bajo condiciones reguladas por un conjunto de procedimientos democráticos aceptados por los adversarios." (Mouffe, 2007:28) De este modo, el modelo adversarial resalta tanto el carácter constitutivo del antagonismo en lo político, como la
} 
concesiones -en definitiva, negociaciones- se vean reducidos significativamente de antemano. Consideramos que organizaciones como el PO, la CCC-PCR, el MPR-QB y el MTR conciben el enfrentamiento político en estos términos, en los que el éxito propio requiere la negación del enemigo político. El antagonismo inherente de lo político se traslada sin mediaciones a las formas de aparición de la política.

Nos parece útil abordar la comparación entre las organizaciones a partir de estas dimensiones ya que consideramos que nos aportan elementos para enriquecer nuestro análisis en tanto cada una de ellas -atendiendo aspectos diferentes, pero complementarios- se vincula de uno u otro modo con la rigidez/flexibilidad que se le asigna a determinadas definiciones políticas; es decir, con las diferentes fijaciones de sentido. En definitiva, creemos que la dialéctica entre la necesidad y la contingencia vuelve a hacerse presente para pensar la relación entre lo económico y lo político, lo estructural y lo superestructural; y pareciera que en el modo en que se plantea tal relación, se pueden identificar algunos elementos que pueden resultar útiles para la comprensión de nuestro problema.

\section{O juremos con gloria morir...}

El tercer tópico que recorrimos en este apartado gira en torno a la llamada "cuestión nacional", específicamente, al modo en que conciben la cuestión de la dependencia y la asimetría entre países centrales y periféricos en relación a la estrategia y objetivos políticos que las organizaciones se dan. Aquí el peso que adquiere la matriz ideológica nacional-popular aparece con claridad estableciendo una frontera de gran nitidez entre las organizaciones que comulgan con ella y las que no.

Para las organizaciones cuyas identidades políticas asociamos a la matriz nacional-popular, la asimetría existente entre los países centrales y los periféricos constituye un tema central para su estrategia política. Destacan el peso que tienen las potencias centrales en las dificultades del desarrollo autóctono, retratado en la histórica connivencia entre elites locales y representantes de los grandes capitales extranjeros. En este esquema resultan fundamentales nociones como las de proteccionismo (vs. librecambismo), mercadointernismo, intervensionismo, Estado de bienestar, etc. La premisa que atraviesa todas estas definiciones es que los países centrales obtienen gran parte de su desarrollo a costa de las espaldas de los países más débiles, es decir que existe una clara relación entre el desarrollo de los países centrales y el subdesarrollo de los periféricos. Desde este enfoque se sostiene que acabar con la dependencia y la sumisión de los países periféricos -en términos 
económicos, políticos y culturales- constituye un objetivo imprescindible para establecer las bases de un país igualitario con perspectivas de desarrollo. Tanto MBPLS, el MUP como el MPR-QB se inscriben, con sus bemoles, claramente en esta perspectiva de análisis.

Como contrapartida, el resto de las organizaciones estudiadas no adscribe a los principales lineamientos de esa perspectiva y destacan la centralidad del conflicto de clases, de dominadores y dominados que se da en el ámbito estrictamente nacional. No se desconocen las asimetrías globales, ni el imperialismo de las potencias mundiales, pero si matizan sus vinculaciones con la desigualdad local. La soberanía política y la independencia económica son consideradas, pero no se las concibe como pasos previos imprescindibles para avanzar en las luchas por una sociedad igualitaria, con justicia social. En algún sentido podemos decir que se desconectan las luchas contra la dominación y desigualdad local de las luchas contra la dominación y desigualdad del plano internacional. La diferencia más tangible en el plano político es la de la promoción de alianzas con la llamada burguesía nacional.

El caso que quizás resulte más problemático para definirlo según estos criterios es el de la CCC-PCR, sobre el que haremos algunas aclaraciones. Si bien esta organización le otorga al imperialismo una centralidad excluyente, que termina adquiriendo un poder explicativo exhaustivo, no deriva en estrategias como las que promueve la matriz nacional-popular. El reconocimiento de la incidencia de las potencias imperialistas no deviene en la necesidad de fortalecer la burguesía nacional, proteger la industria y el mercado interno, sino que opera más bien como un mecanismo de sobredeterminación según el cual a la lucha anticapitalista se le agrega un componente nacionalista, pero que invariablemente aparece subordinado a la perspectiva clasista. Como se observa en varios pasajes del discurso de Ardura, el componente nacional se diluye en la lucha clasista, lo que termina ubicando a la organización en una posición que no muestra demasiadas diferencias con los otros discursos que no comulgan con la matriz nacional-popular.

De este modo, el peso de la cuestión nacional (como aquí fue presentada), se constituye en un fuerte eje de distinción, un punto nodal de lo más relevantes desde el que es posible desarrollar fuertes lógicas diferenciales y equivalenciales al interior del llamado campo popular. La discusión en torno a la pertinencia del fortalecimiento del desarrollo nacional -con la centralidad de la burguesía autóctona- en contra de la dominación extranjera como punto inicial (e imprescindible) para el avance hacia una sociedad igualitaria establece fronteras entre las organizaciones que, en determinadas circunstancias, resultan insalvables. 


\section{CRITERIOS DE VERDAD. CIENCIA Y POLÍTICA.}

Como ya hemos señalado, uno de los elementos centrales que destacan Laclau y Mouffe en su teoría de la articulación política tiene que ver con el nivel de fijación que se establece en los discursos entre los significantes y significados. Desde su enfoque discursivo, lo social siempre aparece indeterminado, sometido a intentos de cierre o sutura que buscan explicarlo, pero estos intentos siempre devienen en parciales, en tanto las fijaciones de significado lo son. Desde este lugar critican vehementemente a aquellas concepciones de lo social que se adjudican cierta verdad última, donde la sociedad aparece como un todo coherente, con fijaciones plenas de sentido. Esto a la vez, suele estar asociado a cierta apelación de lo científico, como saber objetivo que, apoyado en métodos y sistemas determinados, asegurarían la posibilidad de conocer el verdadero sentido de las cosas.

En este apartado exploraremos el modo en que aparecen fundamentadas las distintas afirmaciones de los actores. De esta manera intentaremos ver qué pretensión de verdad ${ }^{89}$ aparece en las miradas de lo social de los distintos actores, entendiéndola como una variable que atraviesa a cada una de las dimensiones que hemos podido observar hasta aquí. Creemos que en este aspecto se pueden reconocer elementos significativos para pensar la articulación política ya que consideramos que el tipo de status otorgado a las verdades propias implica mayor o menor espacio para el entendimiento, el consenso, y por tanto, para la articulación política.

\subsection{Polo Obrero (Partido Obrero)}

Encontramos diversos pasajes en los discursos de los dirigentes de la organización que nos dicen bastante respecto al modo en que presentan sus afirmaciones y argumentaciones. En las palabras de Pablo Rieznik encontramos diversas sentencias que nos permiten identificar algunas posturas que nos dan una pauta de la pretensión de verdad de su discurso.

Una de las proposiciones interesantes es aquella en la que destaca el nivel de conciencia de los militantes de su organización, que por contraste, refiere a los militantes de las otras organizaciones: "El PO tiene una ventaja: declara

\footnotetext{
${ }^{89}$ Con el concepto de pretensión de verdad queremos hacer referencia al espacio que dejan los diferentes discursos identitarios para la puesta en cuestión y discusión tanto de las afirmaciones y juicios sobre la realidad como de las propias posturas, posicionamientos y acciones que se derivan de ellas. Respecto a lo primero nos referimos al grado objetividad -y por tanto de verdad- que se le atribuyen a las diferentes afirmaciones y sentencias que configuran los discursos identitarios. En tal sentido, proposiciones como "Desde mi punto de vista...", "Nosotros creemos que...", etc., serían ejemplos de discursos que encierran pretensiones de verdad más bajas, mientras que "La realidad dice que", "La historia ha demostrado...", indicarían pretensiones de verdad altas. En relación a las posturas y posicionamientos, la alta pretensión de verdad la identificamos en proposiciones del estilo "Somos los únicos que...", "Somos los más combativos/revolucionarios..." en las que se exalta y ensalza el propio posicionamiento en detrimento del comportamiento de las organizaciones pares.
} 
semanalmente sus fines en un periódico que se llama Prensa Obrera, que es un instrumento de formación política de militantes concientes en función de una alternativa obrera y socialista" (Shinzato y Zanzioth, 2007:59). A su vez se resalta el papel de la propia organización respecto a su desempeño en términos de articulación política cuando señala que: "El PO es el que menos divisiones ha sufrido, el que más ha debatido, el que menos sectariamente ha actuado" (Shinzato y Zanzioth, 2007:59) ${ }^{90}$.

Estos elementos resultan más ilustrativos de lo que nos preguntamos cuando los asociamos con determinadas ideas sobre ciencia y política que presenta la organización. Al final de la misma entrevista se le pregunta a Rieznik sobre la estrategia para la toma del poder y respondía lo siguiente:

\begin{abstract}
"Separar políticamente al movimiento obrero de la burguesía y dar una lucha por construir un poder propio. Los elementos de ese poder se conocen desde hace muchísimos años. (...) En (...) Prensa Obrera estamos sacando todas las semanas un análisis de la experiencia de la Revolución Rusa en 1917. Alguien puede decir "ieh! ¿por qué van tan atrás?" ¿La ciencia es así! Nosotros hacemos política como ciencia. ¿O no reposamos sobre los hombros de gigantes como fueron Galileo hace cuatrocientos años, o Newton después, o como fue Einstein sobre la base de Newton y Galileo? ¿No podemos reposar sobre las lecciones de las grandes revoluciones del siglo XX? No, la novedad permanente, el cambio de camiseta todos los días no es ciencia, no es sistemático, no es riguroso, y nosotros hacemos política sistemática, científica y rigurosa" (Shinzato y Zanzioth, 2007:59-60)
\end{abstract}

Se desprenden de aquí una serie de supuestos importantes respecto a lo que venimos observando. En primer lugar la apelación a lo científico como respaldo que sustenta el propio posicionamiento de la organización. Así la estrategia de "separar políticamente al movimiento obrero de la burguesía y dar una lucha por construir un poder propio" y "los elementos de ese poder" aparecen fundamentados por hechos de la historia por todos conocidos, que analizados científicamente conducen a conclusiones que resultan inequívocas; las llamadas lecciones. Surgen de inmediato algunos interrogantes, específicamente si determinados hechos de la historia como "las grandes revoluciones del siglo XX" no están sujetos a múltiples interpretaciones, lecturas $\mathrm{y}$, por consiguiente, a extraer lecciones diferentes que hasta pueden resultar contrapuestas.

En el modo en que Rieznik plantea estas cuestiones subyace el supuesto de que el análisis científico -habría que precisar que se entiende por tal cosa- de la Revolución Rusa otorga elementos y argumentos contundentes para la elaboración de una estrategia política en la Argentina del 2007. Consideramos que desde esta perspectiva se desconoce que todo análisis de cualquier realidad sociohistórica

\footnotetext{
${ }^{90}$ Resulta llamativa la afirmación si la contrastamos con las múltiples y variadas opiniones de las organizaciones pares que señalan lo contrario.
} 
-incluso al interior de un mismo paradigma como podría serlo el marxismo- produce diversas interpretaciones y conclusiones. Dentro de los cánones metodológicos y epistemológicos que podrían definir un análisis científico, existen variadas interpretaciones -al interior y por fuera del marxismo- que no coinciden con las valoraciones y conclusiones a las que arriba el PO. Es decir, la misma Revolución Rusa analizada desde una perspectiva tan pretendidamente científica como la del PO, puede ofrecer $-\mathrm{y}$ en efecto lo hace- conclusiones y lecciones claramente disímiles. ${ }^{91}$

Por último se asocia el mantenimiento de diagnósticos y posturas como bueno en sí mismo, como propiamente científico, en oposición a la "novedad permanente" y al "cambio de camiseta todos los días" que no constituyen actitudes "científicas". Lo científico tiene que ver con lo inmutable, lo que se mantiene. En este caso particular "las enseñanzas de la revolución rusa", que desemboca en defender sus principales lineamientos -o lo que ellos interpretan como sus principales lineamientos- en búsqueda de una política "sistemática, científica y rigurosa".

Consideramos que las citas son bastante claras para considerar a la pretensión de verdad del discurso de la organización como alta, basada en la apelación a cierta verdad científica que permite extraer las correctas lecciones de la historia, las que son transmitidas al conjunto de militantes concientes en una organización que se define a sí misma como la de mejor performace en contra de la fragmentación política del campo popular. De alguna manera se sostiene que las formaciones que no coinciden con los diagnósticos de su propia organización, obedecen a análisis no científicos, es decir de menor validez que los propios. De esta manera, las articulaciones se reducen a convencer al resto para que adhiera a las propias certezas.

\subsection{Corriente Clasista y Combativa}

Como fuimos observando en apartados anteriores, pueden encontrarse claras definiciones sobre las características que debe adquirir el proceso político revolucionario en la Argentina según el programa del PCR. Veíamos que la insurrección armada aparecía como la única vía posible para la transformación social; que era el Partido (el PCR) quien encabezaría la dirección del proletariado; el que a su vez constituye la clase que necesariamente hegemonizará dicho proceso político. ${ }^{92}$

\footnotetext{
${ }^{91}$ Del mismo modo, al mejor estilo del positivismo decimonónico, se pretende establecer una identidad entre las ciencias naturales y sociales, homologándolas, como si se tratara de realidades que pueden ser abordadas con las mismas herramientas y como si su progreso respetara las mismas características. Es decir, mientras que la fuerza de aceleración que provoca la gravedad de la tierra se mantiene constante en $9.8 \mathrm{~m} / \mathrm{s} 2$, desde Newton hasta nuestros días, es claro que el aparato ideológico, político y represivo de las clases dominantes rusas asociadas al Zar Nicolás II, mantienen múltiples y variadas diferencias con los mecanismos hegemónicos que operan en las clases dominantes de la sociedad argentina actual.

92 Dice Ardura: "Los obreros de alta calificación, que son los más explotados desde el punto de vista de la plusvalía -que por supuesto van a ser líderes de la revolución”, (Ardura, 2007).
} 
También se menciona la existencia de etapas ${ }^{93}$-ineludibles- de la revolución y se apela -al igual que veíamos en el caso del PO- a las lecciones de la historia, las que por supuesto son claras, específicas e inequívocas:

"De las grandes revoluciones triunfantes hemos aprendido que la huelga política de masas, el frente único revolucionario, el gobierno provisional basado en los organismos de doble poder y el alzamiento armado del pueblo, deben combinarse para el triunfo de la insurrección." (...)

"En la Argentina, con más del $80 \%$ de población urbana y un gran peso del proletariado, un largo proceso histórico ha demostrado que el camino de la revolución argentina tiene su centro en las ciudades, y a la insurrección armada como forma principal y superior de lucha." (PCR, 2004)

Este tipo de posturas y consideraciones se condicen, al igual que en el caso del $\mathrm{PO}$, con una apelación al saber científico que legitima las consideraciones, valoraciones y conclusiones que se sacan de la historia y que configuran los lineamientos políticos estratégicos de la organización en el presente. Otto Vargas es claro al respecto cuando señala:

"Tenemos la pretensión de ser un partido de vanguardia de la clase obrera y la revolución porque entendemos que nunca ha triunfado una revolución sin un partido que la dirija. Por otro lado, ese partido ha de tener una teoría, y entendemos que el marxismo-leninismo-maoísmo es una teoría científica". (Shinzato/Zanzioth, 2007:160)

En este marco resulta central la crítica al revisionismo respecto a la teoría marxista, el que es visto como una claudicación o degeneración de las ideas verdaderamente revolucionarias. Similar a la crítica de "cambiar de camiseta" que mencionaba Rieznik, la discusión y puesta en tela de juicio de algunos elementos de la teoría marxista es fuertemente condenada y acusada de traición, pese a que en el propio programa se habla de la necesidad de "lucha de opiniones, crítica y autocrítica". Así lo plantea Vargas:

"Nosotros decimos que en 1957 se restauró el capitalismo en la URSS. Del dogmatismo, previo al XX Congreso se pasó al revisionismo, del revisionismo a la traición del movimiento comunista internacional, y de la traición al social imperialismo. (...) El revisionismo del marxismo del XX Congreso planteó la posibilidad del tránsito pacífico al socialismo, el socialismo sin dictadura del proletariado, la posibilidad de que las burguesías nacionales dirigieran los procesos revolucionarios en los

\footnotetext{
${ }^{93}$ Lo que nos interesa resaltar no es la idea de la existencia de etapas en el proceso político de transformación, las que por supuesto existen o pueden identificarse en todo proceso, sino el hecho de que dichas etapas aparezcan preestablecidas.

Dice Otto Vargas: "Entendemos que la revolución en la Argentina es agraria y antiimperialista. No ha sido realizada la revolución democrática. Es cierto que este es un país capitalista, pero no es un país capitalista desarrollado, sino un país dependiente y explotado por varias potencias imperialistas. Por estos motivos creemos que de entrada el socialismo no es posible, y en eso tenemos diferencias con otras tendencias de la izquierda" (Shinzato y Zanzioth, 2007:160).

Del mismo modo, es claro el apartado "Etapas y tareas de la revolución" que aparece en el Programa del PCR (2004) donde se afirma "Somos partidarios de la revolución ininterrumpida y por etapas". En la misma línea aparece con fuerza en el discurso la necesidad de la dictadura del proletariado como etapa ineludible y necesaria.
} 
países dependientes, la alianza con las socialdemocracias en los países capitalistas desarrollados y la coexistencia pacífica como línea fundamental de la Unión Soviética." (Shinzato y Zanzioth, 2007:166)

Y luego señala que:

"El revisionismo es la traición al marxismo-leninismo, es la ideología burguesa dentro del movimiento comunista." (Shinzato y Zanzioth, 2007:176)

Siguiendo esta lógica, el PCR establece como principio central de su programa el mantenimiento y respeto de los principios del marxismo-leninismo entre los que aparece el camino de la insurrección armada, la dictadura del proletariado y las alianzas de clase sujetas a la dirección del proletariado a través de su partido de vanguardia, es decir del propio PCR. El programa es concluyente en este sentido:

"El PCR se propone: mantenerse fiel a los principios del marxismoleninismo-maoísmo y luchar contra el revisionismo; integrar las verdades universales del marxismo con la realidad de la revolución en la Argentina; practicar el estilo marxista-leninista-maoísta de unidad entre la teoría y la práctica, (...) Un partido capaz de garantizar en la lucha, por prevenir el trabajo del enemigo y evitar su degeneración burguesa, la práctica de "los tres sí y los tres no" sintetizados por Mao Tsetung: practicar el marxismo y no el revisionismo; trabajar por la unidad y no por la escisión; actuar en forma franca y honrada y no urdir intrigas y maquinaciones." (PCR, 2004) Las negritas son nuestras.

Por todo esto, siguiendo los parámetros que hemos definido, consideramos que en el caso de la CCC-PCR la pretensión de verdad que se observa en su discurso es alta. Al igual que en el caso del $\mathrm{PO}$, creemos que desde esta perspectiva las posibilidades del acuerdo y el consenso con otras organizaciones se reduce a que las otras organizaciones acepten el propio punto de vista, en tanto este resulta del análisis científico y de las lecciones de la historia.

\subsection{Movimiento de Unidad Popular (MUP)}

Al renegar de muchos de los preceptos del marxismo no hay una apelación explícita a una verdad científica que legitime el accionar político de la organización. Hay muchos planteos que se mencionan en modo potencial y provisorio que denotan la falta de adhesión total a un paradigma específico que funcione como explicación total de lo social. Así no hay un modelo de lucha política específico, etapas necesarias y preestablecidas, sino más bien sentidos y direcciones del accionar que son planteados de modo abierto, sujeto al devenir propio de la realidad política. Un ejemplo de ello es el planteo de que la organización "lucha por la plena vigencia de los derechos sociales, políticos, económicos y culturales" (MUP, 2007) o cuando Martelli planteaba: 
"Me parece que es una búsqueda constante y que no hay una receta. Una búsqueda del equilibrio entre el rol del Estado y la necesidad de la organizaciones social por sobre el individuo y a la vez el respeto a las libertades individuales" (2007).

En el mismo sentido también señalaba:

Me parece [que] muchos grupos no evalúan si la orientación que se toma nos lleva a acercarnos a un objetivo o a alejarnos. Blanco o negro. Lo logramos o no lo logramos. No si está en vías de... (2007)

Esta perspectiva orientada según la matriz ideológica nacional-popular no ofrece una explicación acabada del fin último de a donde se quiere llegar, sino que se mencionan metas en un plano indeterminado ("la plena vigencia de los derechos") que no responden a un modelo social específico ("socialización de los medios de producción", "dictadura del proletariado", etc.). Se identifican sí enemigos y se resalta el sobresaliente papel que juegan los intereses y dinámicas económicas en el orden social. Pero se le otorga mayor espacio a lo contingente, a lo político como dimensión de la resolución de conflictos que no obedece a leyes que lo determinan.

En este sentido planteaba Martelli:

Te ordena la realidad. El desarrollo del proyecto en marcha, para bien o para mal, te ordena. Si este proyecto avanza, las nuevas tareas, los nuevos desafíos ordenan las políticas de alianzas. (2007)

Donde la posibilidad de que el kirchnerismo avance es incierta, por las dificultades de todo proceso, por las contradicciones señaladas y por la propia incertidumbre de las intenciones de quienes dirigen el proyecto político. Para el MUP el kirchnerismo ha mostrado signos que invitan a apoyarlo y a acompañarlo, pero no desconocen sus contradicciones. Aquí cabe señalar que el reconocimiento de las contradicciones -el hecho de que todo proceso político es contradictorio- puede funcionar como un principio ordenador, como un criterio de verdad que termina dando explicación a todo o a casi todo. ${ }^{94}$ Dicho de otro modo, ampliar el espacio de lo contingente, refuerza y autonomiza la dimensión de lo político, pero con el riesgo de colocarse en un plano de indeterminación que desdibuje los horizontes ideológicos. El posibilismo y el cortoplacismo aparecen como posibles vicios en el marco de esta perspectiva. Establecer cuál es el límite tolerable de contradicciones en un proceso político constituye el punto central que define la identidad de una formación política. Más allá de esto, consideramos que la pretensión de verdad que se observa en el discurso de la organización resulta baja.

\footnotetext{
94 En este sentido resulta llamativa la defensa sobre la figura de Scioli, aunque en última instancia se arrojen dudas: "Si se pone, tema por tema a solucionar los problemas de la provincia, me parece un tipo muy capaz. Me parece que además es muy inteligente para saber rodearse de los cuadros políticos necesarios para cada tema. (...) Es una incógnita. No me canso de escuchar gente que dice: fijate que en marzo vamos a tener la primer reunión Scioli-Macri. Ojalá que no.” (Martelli, 2007)
} 


\subsection{Frente Popular Darío Santillán}

Los distintos puntos nodales en torno de los cuales se realizan las operaciones significantes que definen la identidad política de la organización no se estructuran sobre la apelación a un discurso de rigurosidad científica que posea un estatus de verdad superior a otros relatos o tipos de discurso. No hay una visión de la realidad social -un cierre, una operación de sutura- que ofrezca explicaciones acabadas de lo social ni que identifique metas y fines precisos preconcebidos para la estrategia política de la organización.

Fuimos viendo en apartados anteriores diferentes definiciones en las que se renuncia a dar respuestas demasiado rígidas sobre lo social y sobre las características que debe adquirir la práctica política en el tiempo. Claro que hay definiciones que demarcan una identidad política, pero se centran más en principios organizativos, siendo el más importante el de la democracia de base. En la misma línea se destaca la importancia de la cuestión de la autonomía como otro principio de la organización que busca establecer limites a las vinculaciones con otras esferas y espacios de poder. Debemos decir que esta última cuestión puede implicar dificultades para los procesos de articulación política si se eleva a un status absoluto, y que puede derivar en una suerte de ensimismamiento o a un accionar que termine desvinculándose de las dinámicas políticas que imperan.

Resultan ilustrativas otras definiciones políticas como la de cambio social o poder popular ${ }^{95}$, que se presentan como definiciones generales, como grandes trazos de orientación política que no establecen puntos preestablecidos o etapas necesarias. De este modo se manifiesta el deseo de construir un tipo de sociedad no capitalista, pero simultáneamente se define al cambio social -al menos como una posibilidad deseable del mismo- como una fuerte distribución de la riqueza, posibilidad que no implica un modelo rígido de sociedad como lo sería "la dictadura del proletariado" a la que aspiran otras formaciones políticas, al menos como etapa ineludible. Del mismo modo se menciona al socialismo como objetivo político, pero se aclara que su definición estará dada por el sentido que le den los propios protagonistas del cambio.

Esta perspectiva se aleja claramente de miradas históricas teleológicas, que incluyen lógicas inmanentes en el desenvolvimiento del capital o del proceso productivo, de lo cual se deriva una mayor autonomía de lo político, una mayor centralidad de lo contingente. La propia intencionalidad de los actores, según cuenta en sus discursos, busca justamente romper con determinados moldes ideológicos que definan a priori el accionar político. La pretensión de verdad se presenta como baja.

\footnotetext{
${ }^{95}$ Ver el apartado 2.4. sobre la Autodefinición Ideológica.
} 
Sin embargo, volvemos a insistir, el peso que adquiera la autonomía como punto nodal de la identidad de la organización, puede llegar a derivar en estrategias militantes que resten eficacia política. Esto es, todo proceso de articulación política -que creemos necesario para la acumulación y el crecimiento político de las formaciones del campo popular- interpela a la cuestión de la autonomía. El modo en que se resuelva la tensión entre articulación y autonomía será determinante para el desarrollo político de esta formación.

\subsection{MPR-Quebracho}

Si bien no hay una apelación explícita a ningún sistema de verdad científico como aparece en otras organizaciones, sí encontramos algunas definiciones que permiten ver ciertos aspectos que dan una imagen del modo en que la organización construye sus certezas, las características que poseen dichas certezas y las implicancias que tienen para la práctica política.

En primer lugar podemos destacar ciertas menciones respecto al accionar político de otras organizaciones que se formulan desde una pretensión de verdad que califica al accionar de otras organizaciones como equivocaciones o debilidades y no como simples opciones o elecciones que dependen de un análisis diferente. Pese a las aclaraciones y matices hay una fuerte crítica a la inseguridad de muchas organizaciones en el sentido de que renuncian a una práctica consecuentemente revolucionaria.

Esto se ilustra por ejemplo con el debate en torno de la violencia y de la dureza de las acciones políticas de protesta. Esteche resalta en varias oportunidades que se trata de operaciones del gobierno, de los medios, etc., que terminan metiendo estas cuestiones en el debate entre las organizaciones y que por ello las organizaciones inseguras políticamente terminan optando por renunciar a ciertas prácticas. Desde esta perspectiva, se le quita toda legitimidad a dichas discusiones, despojándolas de cualquier análisis -que por ejemplo incluya la lectura sobre la opinión pública- y de toda relevancia. Parecieran concluir que como son discusiones que "meten los medios y el gobierno", no son debates legítimos ni se vinculan con la efectividad política que puede llegar a tener determinada acción política.

En torno a esta cuestión ${ }^{96}$ se aclara que ellos no hacen un juicio valorativo negativo sobre las opciones que eligen las otras organizaciones - "Cosas que no están ni bien ni mal, pero tienen que ver con que cambió" (Esteche, 2007)-, sino sobre el hecho de que son discusiones que "las meten desde afuera". Se deduce, sin embargo,

\footnotetext{
${ }^{96}$ En este caso nos referimos puntualmente al debate sobre la liberación de carriles, el acuerdo con los comerciantes de la zona y la estipulación de horarios para los cortes en el Puente Pueyrredón.
} 
que por ser discusiones "que se meten desde afuera" no son válidas ni legítimas, y que en todo caso sí "están bien o mal" en tanto terminan desembocando en fuertes divisiones como las que sucedieron en relación a los cortes del Puente Pueyrredón.

La cuestión de la violencia es un tópico que atraviesa el discurso de la organización de manera reiterada. Esto, claro está, obedece a que uno de los rasgos por los que se la suele identificar a esta organización suele ser el de su beligerancia. Las argumentaciones sobre el uso de la violencia transitan por tres registros principales que nos parecen útiles describir para este apartado. En primer lugar hay una justificación moral: se recurre a la máxima popularizada por Perón de que "la violencia en manos del pueblo no es violencia sino justicia". Hasta aquí no observamos dificultades, se trata de un juicio moral al que se puede adherir o no a partir de convicciones particulares. Lo que no encontramos es que haya una evaluación política sobre la eficacia de su uso, que es lo que nos parece realmente se pone en discusión por parte de varias organizaciones.

Es más compleja la segunda fundamentación que remite a cuestiones históricas apelando a la figura de San Martín, Güemes, Moreno, Yrigoyen, a las invasiones inglesas, las guerras de la independencia, los levantamientos obreros en Buenos Aires y la Patagonia a principios del siglo XX, la Resistencia Peronista, la lucha antidictatorial y por último a las puebladas y cortes de ruta de los `90s. Todos ellos son mencionados como ejemplos legítimos del uso de la violencia, que en definitiva, legitiman el propio accionar de las organizaciones. Como puede observarse, lo que se desatiende es el análisis del contexto específico y las circunstancias que rodean cada situación concreta y le dan significado a los hechos.

El tercer registro tiene que ver con lo que veíamos más arriba acerca de la construcción discursiva que se hace desde los medios y desde "el poder" respecto al uso de la violencia en la práctica política:

\begin{abstract}
"el pacifismo es una consecuencia de la derrota ideológica: la violencia revolucionaria, la violencia en manos del pueblo, pasa a tener la misma categoría que la violencia social o que la violencia delincuencial, y eso a nosotros nos parece inaceptable, y creemos que se trata de una cuestión ideológica tiene que ver con las derrota de los '70.” (Shinzato y Zanzioth, 2007:182).
\end{abstract}

Desde esta perspectiva, si el pacifismo es consecuencia de una derrota ideológica, hay que hacer "oídos sordos" en tanto no es más que un mecanismo de dominación. Se fundamenta a la violencia porque se interpreta que las objeciones a esta son - ¿exclusivamente?- producto de la propia intencionalidad -“las meten"- de las clases dominantes.

Nos detuvimos en la cuestión de la violencia por dos razones: en primer lugar porque ocupa un lugar central en el discurso y en la práctica de esta organización, y 
en segundo porque se observan en las fundamentaciones criterios de verdad que nos resultan ilustrativos para nuestro trabajo. En primer lugar se da una justificación moral que no responde a la pertinencia de su uso político ni a las críticas que pudieran haber en este sentido. Luego se apela a la enumeración de episodios de nuestra historia que equivalencian su uso más allá de las especificidades de cada caso. Por último se desestiman las críticas -no sólo desde los medios o el gobierno, sino también por parte de organizaciones pares- porque se entienden como impugnaciones originadas desde los sectores dominantes. ${ }^{97}$ En relación a lo que estamos analizando, consideramos que estas operaciones discursivas que fundamentan el uso de la violencia evitan la discusión sobre su efectividad política que, entendemos, es la raíz de los cuestionamientos que provienen de las organizaciones pares.

Anteriormente hicimos algunos comentarios sobre los diferentes usos de perspectivas objetivistas o subjetivistas según el caso, primando una u otra según las valoraciones que se tenga de lo que se evalúa. Así la política derechos humanos y exterior, y el distanciamiento con el FMI del gobierno de Kirchner, aparecen como producto del "momento histórico", del "sentir del pueblo", mientras que todo lo malo que se le achaca aparece como resultado de la propia intencionalidad del sujeto. En esta línea aparecen criterios de verdad tales como la apelación a la "sabiduría de los pueblos" ${ }^{\prime \prime 8}$, que funciona como un elemento explicativo relevante.

Encontramos también menciones autorreferenciales que dan una imagen que parece ubicar a la organización en un lugar privilegiado y de pionero respecto a otras, lo que más allá de la veracidad de tales atribuciones, puede interpretarse como cierta arrogancia política. Uno de los ejemplos se da en relación a su participación en la recuperación y bautismo de la "Casa de la Resistencia Nacional "Diana Esmeralda Teruggi" (nov. 1993), sobre lo que señalan que "en aquellos años reivindicar a las organizaciones armadas de los setenta era dar los primeros pasos de lo que después sería una reivindicación generalizada" (Rubio y Del Grosso, 2005:23). También destacan que "fue la CTD Aníbal Verón la que propició y llevó adelante los primeros cortes de ruta coordinados en los accesos a la Capital Federal, durante julio 2001" (Rubio y Del Grosso, 2005:24). Por último, les parece que "merece destacarse

\footnotetext{
${ }^{97}$ Vale aclarar que no discutimos la hipótesis de que el discurso contra violencia política sea en alguna medida producto de una intencionalidad de los sectores de poder. Lo que sí cuestionamos es que ese hecho implique desestimar automáticamente dichas críticas, si estas tienen sentido en cuanto a la efectividad política de las mismas. Efectividad, que en algún sentido se corresponde con la valoración y el impacto que tienen en las mayorías y en los sectores a los que se quiere interpelar.

98 Si bien nos parece que puede resultar una buena consigna política, la apelación a la "sabiduría de los pueblos" no constituye un argumento consistente: hay tantos ejemplos como contraejemplos que se pueden mencionar respecto a la supuesta sabiduría popular. (Ver cita completa en el apartado 6.5)
} 
que la única presencia estudiantil universitaria en el Puente Pueyrredón" (Rubio y Del Grosso, 2005:25) fueron organizaciones afines a MPR-QB. ${ }^{99}$

En la misma línea hablan de sí mismos como "la organización política popular más referenciada por los argentinos, más conocida hasta en los rincones más lejanos de nuestra tierra", conocimiento que resulta de "su insolencia, su aguante, su seguridad en la definición del enemigo" (Rubio y Del Grosso, 2005:16). También señalan que su organización tiene sobre sus espaldas "la responsabilidad histórica de cuantas expectativas de rebeldía se han ido abonando en nuestra gente con cada una de las luchas que hemos protagonizado", dando batallas "que muchos creen que hay que dar, pero nadie da", "dando la cara en soledad" por "otras expresiones populares que abrigadas por su inseguridad política tiran la piedra pero esconden la mano" (Rubio/Del Grosso, 2005:17).

Creemos que cuantos menos espacios de debate se abren en torno a los posicionamientos políticos propios, menores son las posibilidades de articulación política. En este sentido, vemos que el MPR-QB clausura una serie de discusiones políticas a partir de su seguridad política, que en última instancia desestima las argumentaciones de las otras organizaciones que optan por estrategias diferentes. ${ }^{100}$ Tal perspectiva, asociada a las proposiciones autorreferenciales últimas, nos permite pensar al discurso de esta organización como portador de una alta pretensión de verdad.

\subsection{MTD - Aníbal Verón}

Quizás no haga falta agregar demasiado para observar los principales rasgos del discurso de Daffunchio en relación a este tema. Hemos visto en los apartados anteriores una constante crítica al dogmatismo, a las posturas cerradas e inflexibles, como así también un rescate y una valoración a las posturas contrarias. También observamos varios puntos de autocrítica interesantes, que se vinculan con reformulaciones y cambios a lo largo del tiempo que llevaron a repensar valoraciones anteriores y concepciones teóricas a la luz de elementos que derivan de nuevas interpretaciones sobre el presente. Se reconocen cambios en la visión sobre el Estado, la estrategia política, en la valoración del peronismo ${ }^{101}$, etc. En este sentido, aparece

\footnotetext{
${ }^{99}$ Las negritas son del original.

100 En este sentido, quizás lo más sobresaliente resulte la centralidad que adquiere la lógica insurreccionalista. Es ilustrativo al respecto cuando afirman: "Creemos que es profundizando el camino de la rebelión popular que iremos acumulando y generando las condiciones para la victoria" (Rubio y Del Grosso, 2005:20), donde aparece como indispensable la "calificación militar del pueblo" (Shinzato y Zanzioth, 2007:198).

${ }^{101}$ Sobre el peronismo aparecen afirmaciones como las siguientes: "A Evita también la reivindicaría. Antes no la reivindicaba a Evita. Hace dos años atrás no la reivindicaba a Evita" o cuando le preguntamos por qué reivindicaba más al PRT que a Montoneros que nos respondía que era "Por la ideología, por lo que uno trae, por lo dogmático que uno tiene. Y eso está en revisión. Si me preguntás actualmente, en mi
} 
en las antípodas de los planteos del PCR cuando insiste en luchar contra el revisionismo y los del PO en contra del cambio de camiseta producto de análisis no científicos.

Además de los planteos ya señalados podemos incorporar otras afirmaciones que resultan ilustrativas de este punto de vista. En este sentido se critica explícitamente a la "gente que piensa como en el año 96, ni hablar de los que piensan como en el 74", destacando que "mientras esas cosas no sean superadas, realmente va a ser complicado..." (Daffunchio, 2007). Una fuerte autocrítica recorre todo su discurso, apelando a la necesidad de que la izquierda se haga cargo de sus errores para poder superarlos y no siga buscando responsables en otros y de ese modo evitar el reconocimiento de las falencias propias. Así lo señala en otra parte de la entrevista:

\begin{abstract}
Entonces la gente tampoco come vidrio. ¿Este pueblo, concientemente se va suicidar o va a emprender un proceso en el que pueda perder la vida por estos sectores, por gente que en definitiva es personalista, individualista y que en definitiva no muestra capacidad de maniobra, de poder -poder en el sentido de manejo de la cosa? Y después le terminamos endilgando a la burguesía, al Estado, a los partidos burgueses lo que son nuestros propios problemas: 'El gobierno nos divide'..." (Daffunchio, 2007)
\end{abstract}

Como vemos, aparece una significativa distancia en el modo de concebir la verdad, o las verdades de las que se parte, con respecto a lo que veíamos en otros discursos. No hay una apelación a una verdad científica, que por serla, conduce a que no sea revisada. Repensar y reformular las certezas de las que se parte en el análisis de la realidad social y política, no es visto como una claudicación, resignación o abandono de la verdadera senda revolucionaria, sino un ejercicio indispensable para acceder a un conocimiento más preciso de la realidad.

En este sentido se reconocen las dificultades que existen para llegar a una comprensión y una explicación acabada de la realidad, es decir, la posibilidad de establecer un cierre total en la explicación de lo social. Así, señala que:

"Es muy complicado el mundo en ese sentido, muy interconectado... Más complejo... Además, algunos paradigmas que lo explicaban, no lo explicaban tan bien... En realidad lo que salta es que es difícil de explicarlo..." (Daffunchio, 2007)

Lejos de la pretensión de verdad sobre la que se apoyan otros discursos, Daffunchio resalta la complejidad del mundo y las dificultades para conocerlo, además de reconocer la ineficacia de ciertos paradigmas explicativos. Por todo esto, observamos que su discurso se diferencia considerablemente de otras visiones, en tanto busca poner en cuestión toda una serie de preconceptos y explicaciones totales

cabeza, está en revisión.” (Daffunchio, 2007) 
de lo social, las que desde su punto de vista, es necesario repensar y reformular a la luz de las nuevas realidades en las que toca vivir y se desean transformar.

\subsection{Movimiento Teresa Rodríguez}

Como en las otras organizaciones de matriz marxista-leninista encontramos aquí también una apelación explícita a un saber científico y superior sobre el que descansa el análisis político e ideológico. Algunos de los elementos que podemos rastrear y que resultan relevantes a este respecto son los que aparecen en la publicación Todo o Nada cuando se señala que "si un aporte se puede señalar en Lenin (...) es justamente la explicación científica del significado histórico y político del imperialismo como fase superior del capitalismo, de donde extrae (...) la teoría del eslabón más débil." (2006:10) Del mismo modo, en otra parte señalan que "El Che, la Revolución Cubana y la Historia ya se encargaron de mostrar lo falso y peligroso de esa visión [las estrategias "nacional populares" mediante alianzas con las "burguesías nacionales"], pues termina siempre condenando al fracaso la lucha popular" (2006:11).

Como se ve hay una apelación a ciertas figuras como Lenin o Guevara que funcionan como criterios de verdad, lo mismo que sucede con supuestas lecciones de la Historia, que no permiten interpretaciones diferentes. Del lado de Lenin es claro que se trata de una explicación científica la que explica el funcionamiento del imperialismo y la idea del eslabón más débil. Del mismo modo, el Che, la Revolución Cubana y la Historia, han demostrado que las estrategias nacional-populares conducen al fracaso de la lucha popular. ${ }^{102}$

Pese a reconocer ciertas limitaciones en la capacidad para entender y proyectar un análisis de la realidad social ${ }^{103}$, se descansa en supuestos que actúan como verdades irrefutables ("el único camino es la revolución socialista" o "la necesaria abolición del Estado burgués") como puntos innegociables de la identidad política de la organización. Dicho de otro modo, se reconocen limitaciones personales y de la organización en el análisis de lo social, pero a la vez subyace la idea de un conocimiento que permite una explicación total de lo social, que deriva en verdades absolutas acerca de las contradicciones sociales y de las estrategias políticas pertinentes y necesarias para llevar adelante determinados procesos de transformación política.

\footnotetext{
${ }^{102}$ Es interesante preguntarse por los casos en los que estrategias clasistas y revolucionarias estuvieron lejos de llevar al éxito a la lucha popular.

${ }^{103}$ Martino señala que "no hemos tenido una formación que nos permita ver mucho más allá y poder ser concientes de todo esto" y que "La demanda era tan grande, y nuestra falta de claridad, era tan grande también que terminamos arrastrados en todo esto [las dificultades para superar la práctica reivindicativa]" (Martino, 2007).
} 


\subsection{Barrios de Pie (Libres del Sur)}

En el caso de esta organización encontramos algunos comentarios que nos permiten inferir algunos elementos sobre los criterios de verdad en los que descansa su discurso identitario. Una vez más la "cuestión nacional" aparece como un eje de gran relevancia, ya que es en torno a él que se ordena el mapa político, especialmente en lo que concierne al campo popular. Es a partir del modo en que se concibe la "cuestión nacional" que aparece diferenciado dicho espacio político entre la "izquierda tradicional" y la "nueva izquierda". En este contexto aparecen afirmaciones duras que señalan que la izquierda tradicional "no entiende la contradicción principal, digamos, entre lo que es la nación y el imperio". En un tono similar, pero no exactamente igual, se habla luego de interpretaciones y ya no de entendimiento. La diferencia puede ser significativa, en tanto una cosa es entender algo que es entendible y otra cosa es interpretar, lo que implicaría la posibilidad de diferentes interpretaciones. La distinción, sin embargo se esfuma cuando se habla de "interpretar claramente", esto es, se habla de una interpretación que resulta clara, mientras las otras no lo son.

Todas estas críticas sobre las diferencias ideológicas que se distinguen respecto a la izquierda tradicional conducen a un fuerte distanciamiento y a adjetivaciones peyorativas como la del "infantilismo" de la izquierda. En la misma medida se defiende la posición de la propia organización como "un gran acierto" en la comprensión "de la nueva etapa que se ha abierto en el mundo, en Latinoamérica y en la Argentina" (Libres del Sur, 2008)

Ahora bien, más allá de estas afirmaciones, adjetivaciones peyorativas y pretensiones de verdad frente a los "desaciertos" de otras organizaciones, no hay en el discurso de la organización un diagnóstico cerrado sobre el acontecer político, sobre las fuerzas en disputa, ni sobre determinaciones. Vemos, por ejemplo que se ponen reparos sobre el devenir del proyecto político del kirchnerismo del que forman parte, atentos a como se desarrollen los acontecimientos. Así plantean la posibilidad de que se forme una fuerza que represente los intereses nacional populares, que puede estar "más afuera o más dentro" del kirchnerismo, que posiblemente se constituya en un aliado, o no.

De la misma manera no hay una pretensión de constituirse en "la fuerza" o "el partido" de la clase trabajadora, se definen como una formación política que participa de un proceso más amplio, que constituyen junto con otras fuerzas el "andarivel izquierdo del kirchnerismo" y que buscan formar parte de un Frente Nacional-Popular, pero no hacerlo ellos ni ser la vanguardia que "marque el camino". Del mismo modo no se menciona la existencia de sujetos sociales privilegiados para la acción política, ni 
tampoco de una estrategia o modalidad política para avanzar en procesos de transformación social.

Todos estos elementos nos acercan una aproximación sobre la pretensión de verdad que muestra la organización que, creemos, se vincula fuertemente con las estrategias -y las posibilidades- de articulación política. En líneas generales, y más allá de las salvedades enunciadas, no consideramos al discurso de esta organización como portador de una alta pretensión de verdad. No observamos ni una apelación a cierta verdad científica objetiva, ni explicaciones exhaustivas de lo social, ni menciones autorreferenciales en las que la propia organización aparezca destacándose sobre el resto por ser "la más..." o "la primera...".

\subsection{Pretensión de verdad o espacios que se abren para "ponernos de acuerdo"}

Todos los discursos identitarios suponen, de algún modo, que el propio posicionamiento es el correcto, el acertado. No hace falta remitirnos a las organizaciones del campo popular, también sucede con las propias creencias personales. Cada quien elabora un análisis de la realidad, toma posiciones al respecto y está dispuesto a defender tales posicionamientos. Ahora bien, la defensa de la propia postura, y de los supuestos en los que se apoya, puede adquirir características variadas. Esto es lo que buscamos explorar en este apartado, ya que creemos que tales características actúan en las posibilidades de articulación política.

\begin{tabular}{|c|c|}
$\begin{array}{c}\text { Pretensión de verdad del discurso identitario } \\
\text { BAJA }\end{array}$ & ALTA \\
\hline MUP & PO \\
\hline FPDS & CCC-PCR \\
\hline MTD-AV & MPR-QB \\
\hline MBP-LS & MTR \\
\hline
\end{tabular}

En rigor, en los apartados anteriores ya fuimos observando de qué manera se posicionaban los referentes de las organizaciones y el tipo de fijación de sentido que se le imprimía a los diagnósticos y supuestos sobre los que se apoyaban tales posturas. No es novedad a esta altura del trabajo, observar en el discurso de las organizaciones más cercanas al marxismo-leninismo, las fijaciones más rígidas, que a su vez devienen en posturas que resultan menos flexibles. Resulta esperable que desde una matriz ideológica como la marxista se estructuren discursos atravesados por enunciados esencialistas y necesarios -sobre sujetos políticos privilegiados, formas específicas de acción, etapas y características del proceso de transformación social, etc.- que revisten a tales discursos de una alta pretensión de verdad.

Pueden distinguirse distintas formas en las que se promueve un discurso con alta pretensión de verdad. Una de ellas, quizás la más evidente, es la que resulta de la 
apelación a cierto status científico sobre el que se basa el discurso. Desde esta perspectiva la opción por determinada postura descansa en un análisis, que por ser científico, deviene en superior a los análisis considerados no científicos. En la misma línea, en estos discursos se suele identificar a lo que se percibe como cambio de postura -"cambio de camiseta", "revisionismo"- como claudicación respecto al conocimiento propiamente científico y objetivo; claudicación que es indicador de la aceptación de los valores del propio enemigo político -la burguesía- y del renunciamiento a la verdadera senda revolucionaria. Esto es, -el cambio es fuertemente asociado a la derrota y traición. Finalmente también encontramos una serie de proposiciones autorreferenciales que insisten en presentar a la propia organización como la más avanzada, la más coherente, la más revolucionaria, valiente, la menos sectaria, etc.; discursos que permiten suponer una reducción del espacio disponible para la posibilidad de avanzar en consensos.

Consideramos que lo que llamamos la pretensión de verdad de los discursos identitarios constituye un elemento no desdeñable para pensar las posibilidades que se abren o se cierran para el desarrollo de procesos de articulación política entre las organizaciones del campo popular. Como decíamos al principio, nos parece un aspecto de gran centraldiad que sobrevuela cada uno de los posicionamientos de las distintas organizaciones. Creemos que en este punto existe una diferencia significativa entre las organizaciones cercanas a la matriz marxista-leninista y las que no; y que tales diferencias obedecen a los supuestos teóricos sobre los que descansa aquella matriz. Por todo esto nos parece interesante hacer foco en esta cuestión en tanto la vinculamos directamente con las posibilidades avanzar en acuerdos y coincidencias, y, por tanto, en procesos de articulación política de alta intensidad. 


\section{TERCERA PARTE: CONCLUSIONES}

\section{TIPOS DE SUTURA, FIJACIONES DE SENTIDO Y ARTICULACIÓN POLÍTICA}

"El espacio de la hegemonía (...) es el del estallido de una concepción de la inteligibilidad de lo social que reduce sus distintos momentos a la interioridad de un paradigma cerrado"

(Laclau / Mouffe, 2006:129).

\subsection{De cada pueblo un paisano. Lo que deja el análisis de cada organización.}

\section{El PO y la incansable búsqueda de la independencia de clase.}

De las organizaciones que observamos para nuestra investigación, el PO, autodefinida como marxista-leninista-trotskista, constituye una de las que establecen un tipo de cierre de lo social más rígido y determinado. Hay en su discurso una concepción -y explicación- de lo social según la cual se reduce notablemente el espacio de lo contingente y de lo indeterminado, subordinándolo a grandes coordenadas con un poder explicativo total.

En primer término, el orden social es entendido a partir de la radical oposición entre sus clases fundamentales: la burguesía y el proletariado. En la lógica de la organización, la clase obrera es el sujeto político por excelencia, y la apelación a otros actores sociales sólo se piensa de modo accesorio, apoyando la gesta genuinamente proletaria y, por supuesto, subordinado a ella. Hasta aquí un primer cierre que reduce el margen de maniobra: el sujeto político está plenamente definido y hay un fuerte celo en respetar el carácter obrero del partido: la independencia de clase aparece como el valor central desde el que el PO construye sus sucesivas lógicas diferenciales.

Se parte de una perspectiva que incluye un alto grado de determinación socioeconómica sobre la dimensión de lo político, en tanto los actores políticos vienen preconstituidos desde su lugar en la estructura económica. El papel de lo político se reduce así a conectar su posición objetiva con su misión política, despertar su conciencia de clase, pasar de la clase en sí a la clase para sí. Es a este tipo de posicionamiento al que refieren Laclau y Mouffe (2006) cuando describen los elementos esencialistas presentes en el marxismo: la ubicación socio-económica del sujeto deviene en esencia política. Por ser un obrero tiene determinada misión histórica que cumplir, realizar determinados intereses de clase. ${ }^{104}$

Desde nuestra perspectiva creemos que este tipo de cierre genera inconvenientes a la hora de desarrollar procesos de articulación política de alta intensidad, en tanto se limita la posibilidad de poder ampliar el espacio político mediante el desarrollo de lógicas equivalenciales que permitan construir un sujeto

\footnotetext{
104 Señalan Laclau y Mouffe que "El problema con estos autores que parten de una definición restringida de la clase obrera es, sin embargo, que se fundan en una noción de "interés objetivo" carente de todo basamento teórico y que es escasamente más que la atribución arbitraria de intereses, por parte del analista, a ciertos agentes sociales."(Laclau y Mouffe, [1985] 2006:122)
} 
político que exceda el estricto corte de clase, por otro lado, originado en otra dimensión social. La articulación política se ve así restringida de antemano en tanto hay una fijación de significado plena del sujeto político (dimensión política) respecto de la clase obrera (dimensión económica). El sujeto político de la transformación social es la clase obrera, y mantener su independencia política resulta la empresa más importante desde la perspectiva de la organización.

Esto se ve con claridad cuando se analizan las menciones de la propia organización respecto a sus pares. En líneas generales se aprecian críticas a todas o casi todas las organizaciones del campo popular, todas ellas vinculadas con el hecho de alejarse del modelo obrero céntrico y, por tal motivo, de alejarse de la verdadera senda revolucionaria. Es decir, las otras organizaciones no son criticadas por "pensar o ver las cosas de modo diferente", sino por no ser revolucionarios, lo cual aparece como mucho más grave. Aparece un elemento ético-moral que no es desdeñable.

El tipo de cierre, el tipo de aprehensión que se hace del universo social, deriva en una serie de determinaciones lógicas que establecen rígidamente las características que ha de adoptar el modelo social que debe ser construido en alternativa al estado actual de cosas. La sociedad capitalista es una sociedad atravesada por una contradicción fundamental entre burguesía y proletariado la que debe ser resuelta mediante la socialización de los medios de producción, en su lenguaje, la implantación de un Estado obrero y socialista. Toda construcción política que no esté orientada hacia esa dirección es desestimada y forma parte del gran universo de los desaciertos, traiciones y alternativas del propio sistema a la genuina lucha de la clase trabajadora. Desde esta perspectiva las actuales experiencias políticas de Venezuela y Bolivia son definidas como nacionalismos burgueses, tibios procesos de transformación, que terminan obstaculizando y debilitando el impulso revolucionario de los sectores populares de cada uno de estos países.

Esto se acompaña con una alta pretensión de verdad que se apoya en la apelación a determinado saber científico como basamento de su verdad y sus argumentaciones. Señalan los dirigentes del PO que su organización -"a diferencia de otras"- hace "política como ciencia" y critican airadamente la "novedad permanente, el cambio de camiseta todos los días", ya que eso "no es ciencia, no es sistemático, no es riguroso, y (...) [ellos hacen] política sistemática, científica y rigurosa”. De esta manera los rígidos cierres de lo social y las fijaciones de sentido resultantes, se resguardan en una apelación a la verdad científica que a la vez designa el cambio de perspectiva como "no sistemático, no riguroso, no científico".

En definitiva, el discurso que encontramos en esta organización aparece en sus principales trazos atravesado por rígidas fijaciones de sentido que derivan de 
posiciones esencialistas y que restringen el espacio de lo contingente. Desde nuestra perspectiva de análisis, creemos que dichas características reducen la posibilidad de desarrollar equivalencias que amplíen el campo de las articulaciones políticas.

\section{CCC-PCR, enumeración comunista y reducción imperialista}

Son varios los elementos que identificamos en el discurso identitario de la organización en los que se establecen límites importantes con las otras. Hay una fijación primaria que se origina en el planteamiento de la organización de autodefinirse como "el partido político revolucionario del proletariado". Esta definición primaria deriva en varias cuestiones de relevancia, la primera y más importante es que reduce la articulación a que el resto de las organizaciones reconozca su rol de ser "el partido revolucionario del proletariado". Si bien en su práctica, la CCC-PCR mantiene una postura abierta de alianzas políticas, por las definiciones que encontramos en su discurso, pareciera que estas se establecen en un plano táctico, son concebidas como medios de acumulación política, pero no en el sentido de articulaciones políticas de alta intensidad. Es decir, las alianzas políticas se circunscriben a un plano instrumental, en acuerdos programáticos, pero que nunca desafían los rígidos principios identitarios.

A diferencia del PO, la CCC-PCR flexibiliza la centralidad de la clase obrera, dándole protagonismo a otros sectores sociales, definidos según criterios diversos, lo que trae algunas complicaciones. Así aparecen definidos como potenciales aliados políticos, el proletariado industrial y el campesinado pobre junto con los estudiantes, las mujeres, sectores de la pequeña burguesía, etc., donde se superponen distintos criterios de distinción de los sujetos a los que se apela (género, nivel educativo, etc.). Más allá de estas observaciones, la CCC-PCR desarrolla lo que Laclau y Mouffe (2006) Ilaman la enumeración comunista, una búsqueda de articular diferentes sectores sociales, pero que no subvierte el rol central del proletariado y en última instancia ocupa la dirección del proceso político. A partir de este tipo de ejemplos Laclau y Mouffe distinguen entre alianzas de clase y articulaciones hegemónicas, siendo las primeras "de carácter factual o episódico" en tanto no logran construir un equivalente general que desborde el contenedor de la clase. De este modo, la reconocida vocación articulatoria de la organización -que incluye la posibilidad de alianzas con sectores de la burguesía nacional- se inscribe en un rígido sistema teórico que, a partir de definiciones determinantes, obstaculiza la profundización de los procesos de articulación política que deriven en modalidades de alta intensidad.

Respecto al tipo de construcción política y las características de lo que "está por venir", las definiciones adquieren una rigidez mayor. No sólo se concibe al 
socialismo como algo claro y definido a partir de una serie de rasgos preestablecidos, sino que además se proclama la inevitabilidad tanto de la vía insurreccional como de la dictadura del proletariado. Así se definen a priori diversos tópicos que, creemos, traen consecuencias para las posibilidades de profundizar articulaciones políticas. La intensidad con que se plantean las críticas hacia los "cretinos parlamentaristas" que optan por participar en contiendas electorales o hacia organizaciones como la CTA por apartarse del clasismo y "estar con el kirchnerismo", nos parecen ejemplos de la fuerza que adquiere la lógica diferencial a partir de determinadas fijaciones de sentido.

Al igual que en el caso del PO, todas estas definiciones se apoyan en una alta pretensión de verdad mediante la apelación a un saber científico que da a determinadas interpretaciones de la historia y de la realidad social, el status de verdades inequívocas "científicamente comprobadas". Consideramos que esta cuestión dificulta más aún el entendimiento con otras organizaciones, particularmente cuando se hace especial hincapié en "luchar contra el revisionismo" y en la defensa de las "verdades universales del marxismo".

Por último, el análisis del escenario político y la caracterización de sus actores aparecen determinados por la variable del imperialismo, la que termina explicando todas o casi todas las vicisitudes de la política, reduciendo casi a cero la posibilidad de otorgarle rasgos autónomos a aquella dimensión. Algunos de los ejemplos que ilustran esto los vimos cuando "la crisis de las papeleras" era explicada porque a Tabaré Vásquez lo respalda un imperialismo ruso distinto al imperialismo ruso que apoya a Kirchner; cuando el golpe de Estado a Chávez y su fracaso se explicaba por los distintos imperialismos en pugna; o cuando se explicaban las reformas en las FFAA en nuestro país por la presión del imperialismo chino para neutralizar la hegemonía de los sectores pro rusos enquistados allí. Mediante operaciones de este tipo, lo político se reduce a los designios de los poderes imperialistas y se desatiende cualquier tipo de mediación y autonomía de la dinámica política. A esto nos referimos cuando hablamos de reducción imperialista.

Consideramos que esta perspectiva deriva en una visión de lo político que lo concibe como una suerte de prolongación -automática y coherente- de la dinámica económica -en este caso imperialista. De este modo quedan definidos dos grandes campos políticos, el campo popular (que como veíamos, en última instancia remite al proletariado industrial) y el anti-popular. Sin embargo, hecho que se repite en muchas de las organizaciones, esto no se traduce en la conformación de dos bloques políticos constituidos y enfrentados. Proliferan al interior del campo popular múltiples lógicas diferenciales que impiden la consolidación política del bloque, mientras que en cada operación de diferenciación se avanza en el fortalecimiento del bloque contrario. Se 
avanza de este modo en un proceso de diferenciación al interior del propio campo de alianzas y de homologación al interior del campo enemigo. ${ }^{105}$

Por lo analizado hasta aquí, entendemos que la CCC-PCR presenta un discurso que en algunos aspectos se muestra con una fuerte propensión hacia la articulación política, pero que simultáneamente incluye fijaciones de sentido que establecen importantes límites para la profundización de dichos procesos articulatorios. La centralidad explicativa que adquiere y el modo en que es utilizada la "cuestión del imperialismo" sin dudas constituye un rasgo distintivo que, junto con otros elementos identitarios -como la traslación del esquema dicotómico marxista al escenario político-, pueden contribuir a una comprensión más precisa de la performance política de la organización.

\section{MTR, revolución y reforma}

La tercera organización que se autodefine al interior del campo marxistaleninista es la que encabeza Roberto Martino, quienes se definen como guevaristas, por lo que entienden el marxismo leninismo de estos tiempos y latitudes. Al igual que los casos anteriores se observan una serie de supuestos teóricos con una plena fijación de sentido que preconstituyen el escenario político. En términos más claros, aparecen preestablecidos: el camino, los diferentes pasos, los sujetos y el objetivo último del proceso de transformación social, los que no admiten demasiadas alternativas. Entre estos elementos aparece con fuerza, como punto nodal del que se desprende una fuerte lógica diferencial, la inevitabilidad de la revolución entendida como la destrucción del Estado burgués. En otros términos se resalta la inviabilidad de procesos de transformación basados en sucesivas reformas en el marco de las instituciones vigentes.

Respecto a las organizaciones pares del campo popular aparecen algunos signos de amplitud y flexibilidad, en especial respecto a la Paritaria (o Constituyente) Social impulsada por la CTA, la que es vista con expectativas como un camino de construcción interesante. Pero del mismo modo no se abandonan las definiciones más

\footnotetext{
${ }^{105}$ En el caso de la CCC-PCR, esta situación se ve acompañada por lo que llamamos la reducción imperialista. La fuerza y la independencia con la que es concebida la variable de imperialismo, al interior de las coordenadas antes descriptas, pareciera estar en la base de las alianzas programáticas con sectores como las corporaciones patronales del agro, consideradas por la casi totalidad de las organizaciones pares como "históricos" y claros enemigos del campo popular. En este caso, el gobierno nacional es identificado como representante directo de una serie de poderes imperiales (europeos, rusos, chinos, yanquis, etc.) y las alianzas necesarias para enfrentarlo (articulaciones de baja intensidad) aceptan el acercamiento con sectores tradicionalmente definidos con la derecha política e ideológica del país.

El peso de la lógica insurreccional también parece tener su peso explicativo en relación a este caso, en tanto se acopla con el clima de desestabilización política impulsado por los referentes de las corporaciones rurales.
} 
rígidas señaladas más arriba y se habla de las organizaciones que "están enfermas con el virus del reformismo".

Al igual que en los casos anteriores, el espacio político aparece escasamente diferenciado, atravesado por la contradicción de clase fundamental entre burguesía y proletariado. En este sentido, carece de relevancia la distinción entre el kirchnerismo y sectores de la oposición como Mauricio Macri, López Murphy, etc.: todos constituyen el amplio espacio de "gerentes de la clase capitalista". Sucede lo mismo en el ámbito de los medios: no aparecen diferencias relevantes entre Horacio Verbitsky, Mariano Grondona y Rosendo Fraga: sin diferencias de grado, todos resguardan los intereses de la burguesía. ${ }^{106}$

Como decíamos anteriormente, las definiciones más inflexibles se centran en una concepción del proceso de transformación social predeterminado en términos de revolución, con la necesaria destrucción del Estado, la inviabilidad de las reformas y la concepción del socialismo definida en los términos más clásicos. Estas cuestiones aparecen con claridad cuando se critican los distintos procesos políticos latinoamericanos por su distancia y alejamiento de la senda socialista. Así las dirigencias políticas brasilera, uruguaya, boliviana, cubana y venezolana, son criticadas en distintos términos según el caso, pero con la misma orientación general: alejarse de los lineamientos que marca el modelo revolucionario leninista, en definitiva, de "ser reformistas, no proletarias".

Por último, y siguiendo la línea de las otras organizaciones marxistas-leninistas, aparece una alta pretensión de verdad que se apoya en la apelación del carácter científico de los supuestos en los que se apoyan sus posicionamientos. Se mencionan por ejemplo el aporte de Lenin y su "explicación científica del significado histórico y político del imperialismo", como así también la contundencia de las demostraciones que "El Che, la Revolución Cubana y la Historia" hicieron sobre el peligro de las estrategias políticas nacional-populares. Esta concepción del conocimiento y de la verdad deriva en definiciones que se plantean en términos absolutos como que "el único camino es la revolución socialista" o sobre "la necesaria abolición del Estado burgués".

La dicotomización del espacio político a partir de la traslación de la contradicción fundamental, sumada a una serie de definiciones políticas que predeterminan los principales rasgos del proceso de transformación que se quiere llevar adelante, parecieran incidir negativamente en la posibilidades de desarrollar

\footnotetext{
${ }^{106}$ Como vimos anteriormente, estas categorizaciones conducen a ciertas complicaciones cuando luego se señala que "las clases dominantes sí están planteando una agenda de cambio, de giro conservador" y se mencionan a Macri, a la Sociedad Rural, a Grondona, la Fundación Tel Aviv y las cámaras empresariales que presionan al kirchnerismo para la reinserción de Argentina en el mundo, el pago al Club de París, el monitoreo del FMI, eliminación de las retenciones y la liberación de tarifas.
} 
procesos de articulación política. Como señalábamos más arriba, entendemos que la traducción política de la contradicción burguesía-proletariado, se lleva a cabo desestimando graduaciones, que en el escenario político parecieran relevantes. Esta decodificación binaria del mapa político coincide, a su vez, con una visión del proceso de transformación social que aparece predeterminado en varios de sus aspectos fundamentales. Creemos que la conjunción de ambos elementos conduce a que las diferencias que se presentan con otros posicionamientos adquieran una dimensión tal que termina restringiendo el espacio para las operaciones articulatorias.

\section{MPR-Quebracho, la difícil síntesis entre el nacionalismo popular y el marxismo leninismo.}

Reticentes a las etiquetas y a definiciones de corte ideológico, los dirigentes de esta organización hacen hincapié en la práctica política como criterio de definición. Desde este punto de partida, se le da a la práctica, al quehacer, a las protestas y manifestaciones -las acciones públicas en las que la organización se hace ver- una centralidad que no aparece en otras organizaciones (quizás se vea en el FPDS, aunque de otra manera). Ahora bien, más allá de estas reticencias, son claras algunas definiciones ideológicas que hacen referencia al patriotismo revolucionario, la búsqueda de la liberación nacional y social de la Patria, la revolución nacional antiimperialista. Es decir, en sus definiciones ideológicas, la cuestión nacional-popular adquiere una centralidad evidente y todo el discurso se construye en derredor de dicho tópico, pero además se señala la presencia -e importancia- del marxismo-leninismo "en cuanto a cosmovisión del mundo, categorías de análisis y filosofía política". Ambos ascendentes ideológicos, conjugados con la centralidad de la práctica política antes mencionada, le otorgan a la lógica insurreccionalista una gravitación sobresaliente. En el intento de síntesis de estos elementos creemos que se pueden deducir ciertas lógicas que operan en las diferentes definiciones de la organización y sus consecuencias respecto a la articulación política.

En efecto, resulta interesante el modo en que se articulan en el discurso los diferentes elementos antes mencionados, en donde la matriz ideológica nacionalpopular se ve interpelada por la lógica marxista-leninista, que, a partir del peso que termina adquiriendo la práctica política, le otorga a la lógica insurreccional una centralidad que recorre todo su discurso. Tal protagonismo se enmarca en otro rasgo común entre las organizaciones marxistas-leninistas exploradas que es la primacía del criterio schmittiano amigo-enemigo para pensar los antagonismos políticos y sus posibilidades de resolución. Por estas cuestiones vemos en el derrotero de la organización similitudes con referentes opositores "nacional-populares" (se menciona 
a Mario Cafiero, Claudio Lozano y a Pino Solanas), pero acercamientos en política con organizaciones con fuerte gravitación de lógica insurreccional enmarcada en una matriz marxista-leninista, puntualmente se menciona el caso del PCR.

En el mismo sentido, la postura que adopta respecto al kirchnerismo es radicalmente opositora, alejándose de las organizaciones "nacional-populares" observadas que lo apoyan en diferente grado y medida. El escenario político es atravesado por la contradicción fundamental entre patria vs. entrega, y es al interior de esos campos que operan las lógicas equivalenciales que configuran el diagnóstico sobre el conjunto de los actores políticos. Del mismo modo que en los discursos anteriores, no tiene demasiada relevancia diferenciar, establecer graduaciones al interior de estos campos: las clases dominantes económicas cuentan con sus gerenciadores entre los que se incluye a la clase política, las fuerzas de seguridad de justicia y los grandes medios. Respecto al escenario político, la "clase política" opera como un todo en el que no aparecen demasiadas distinciones.

Finalmente creemos identificar en el discurso de la organización una alta pretensión de verdad que no se traduce en la apelación a un saber científico-objetivo, pero sí en la autoproclamación recurrente de encabezar diferentes ranking como el de la combatividad, seguridad/convencimiento, nivel de conocimiento y referencia a nivel nacional, reivindicación de la lucha de los setenta, presencia de estudiantes en determinadas jornadas, desarrollo de cortes coordinados en Capital... Del mismo modo, se desestiman ciertos debates, específicamente el del uso de la violencia en la práctica política, porque se argumenta que se trata de un debate instalado por las clases dominantes, que se trata de una derrota ideológica. Son notables las semejanzas con la "lucha contra el revisionismo" y rechazo al "cambio de camiseta", en tanto en todos los casos se asocia la puesta en discusión de determinados elementos con la claudicación o la traición del accionar verdaderamente revolucionario. Tal operación funciona como un buen mecanismo para clausurar de antemano la posibilidad de avanzar en determinados debates.

La apelación a elementos de la matriz nacional-popular, le da a la organización la posibilidad de flexibilizar ciertos elementos que en la matriz marxista-leninista aparecen expuestos con gran rigidez. A diferencia del PO, la CCC-PCR y el MTR, no hay una definición cerrada sobre las características del Estado y su rol en el proceso de transformación (no se plantea su necesaria destrucción), no hay una apelación a un sujeto político específico preconstituido en la esfera de lo económico, como tampoco se habla de la dictadura del proletariado como etapa inevitable del proceso de transformación social. Sin embargo, la posibilidad de desarrollar articulaciones mediante el juego equivalencial de significantes vacíos y flotantes, se ve fuertemente 
limitada a partir de la centralidad que adquiere la lógica insurreccional, que se termina constituyendo en un camino necesario, inevitable, de tal transformación. La poca flexibilidad en torno a este punto, sumada a la alta pretensión de verdad que identificamos en el discurso, parecen reducir el espacio del juego político -y de la articulación- que posibilitaban aquellos elementos que aparecían indeterminados y sujetos a la contingencia.

\section{MUP y fijación de sentido en la coyuntura política}

Como pudimos observar a lo largo del trabajo, se produce en esta organización una peculiar transición desde una matriz ideológica de orientación anarquista hacia una nacional-popular. En los hechos, los vestigios libertarios se ven fuertemente absorbidos por el discurso de matriz nacional-popular, lo que no es ocultado, sino resaltado como un cambio de visión, de postura, de maduración, etc. A diferencia de otros discursos, el cambio -de perspectiva, de postura- no es entendido como una traición o claudicación, sino más bien como una evolución lógica y necesaria.

Es enmarcada en las coordenadas nacional-populares que la organización concibe el cambio social como un proceso que puede ser gradual, a partir de reformas desde las instituciones vigentes. Hay una concepción sobre el Estado claramente diferente a la que se desprende del marxismo-leninismo según la cual el Estado constituye el gerente político de los intereses de la burguesía. Para el enfoque nacional-popular, el Estado es una herramienta del cuerpo social que está en disputa y que vale la pena disputar para hacerlo jugar a favor de los sectores populares. La perspectiva de cambio no se reduce entonces a una necesaria revolución en el sentido leninista que implica la destrucción de las instituciones estatales actuales, en tanto prevé la posibilidad de avances graduales y de un Estado disciplinando a los sectores dominantes. La contradicción política central que se señala es la del proyecto nacional vs. proyecto liberal. La experiencia del peronismo constituye la principal referencia histórica de nuestro país, mientras que los actuales procesos de Venezuela, Bolivia y Ecuador, aparecen como los ejemplos actuales más claros del continente. En el mismo sentido hay una valoración general de los procesos políticos latinoamericanos en la que se hace especial hincapié en la necesidad de fortalecer la integración regional, más allá de las diferencias que pudieran observarse.

La gradualidad en la concepción del proceso de transformación se corresponde con una diferenciación del espacio político y una complejización mayor de los actores que en otros planteos. Es decir, no hay una identificación plena entre actores económicos y clase política como un todo, entre la ingerencia de determinada potencia imperialista y la política respecto a las FFAA, etc. Desde la perspectiva de la 
organización los actores son variados y complejos, plagados de contradicciones y cada uno posee sus intereses particulares y sus dinámicas propias. Esto no los lleva a desconocer el peso de los intereses económicos que están en juego en el escenario político, pero le otorga un nivel mayor de autonomía a la dimensión de la política. Desde esta perspectiva aparecen con gran centralidad la referencia a otros actores de la llamada clase política, según la cual se fundamenta el apoyo al kirchnerismo desde la idea de que "en política no hay lugares vacíos" y que las otras opciones con posibilidades reales de transformarse en alternativas de poder resultan más perjudiciales para el avance hacia una sociedad menos desigual. Del mismo modo se justifica la convivencia al interior del heterogéneo espectro kirchnerista -así se lo concibe- con ciertos sectores identificados con la vieja política desde la lógica que es preferible tenerlos de amigos que de enemigos.

En líneas generales podemos señalar que la perspectiva de análisis que propone la organización pretende distanciarse de los lineamientos de la matriz marxista-leninista, buscando así evitar determinadas fijaciones de sentido que impliquen una mayor rigidez en sus definiciones políticas. El escenario resultante no implica ni un sujeto político privilegiado, ni un método de construcción política determinado, ni etapas o medidas necesarias e ineludibles ("dictadura del proletariado", "destrucción del Estado burgués" o "socialización de los medios de producción"). En vez de ello se concibe un escenario fuertemente atravesado por la contingencia, con actores políticos contradictorios y portadores de dinámicas e intereses propios, en el que se debe avanzar en la acumulación de poder político por parte de quienes buscan representar los intereses de los sectores populares.

El tipo de sutura desde la que se concibe el universo social y sus derivaciones respecto de la esfera de lo político, presenta un escenario que en varios puntos relevantes resulta indeterminado, lo que pareciera otorgar un mayor espacio para la articulación política en tanto no se establecen demasiados lineamientos a priori que imposibiliten la operación de vaciar significantes. Sin embargo, del mismo modo se corre el riesgo de que la relativización se convierta en absoluto, esto es, que el reconocimiento de las contradicciones y dinámicas propias de la esfera de lo político debiliten, hasta que resulten políticamente ineficaces, los límites de la propia identidad política. En otras palabras, el proceso de deconstrucción de determinados supuestos esencialistas puede conducir a la sobredeterminación de la coyuntura política sobre el resto de los elementos del discurso identitario.

El tipo de adhesión que la organización establece con el kirchnerismo, la fijación de sentido que se construye al respecto, puede reducir el espacio del entendimiento y por tanto el de la articulación. Un síntoma de esto podemos 
encontrarlo en la visión de las otras organizaciones, en la que encontramos que en tres de los cinco indicadores que utilizamos se denotan ciertas dificultades para la articulación. ${ }^{107}$ Más allá de cualquier juicio de valor, lo que nos interesa aquí es señalar los límites que observamos en cuanto a la articulación política.

\section{Barrios de Pie y kirchnerismo crítico}

Barrios de Pie-Libres del Sur (MBP-LS) al igual que el MUP es una de las formaciones que, aunque en la actualidad haya tomado distancia, decidieron acompañar el proyecto político encabezado por la figura del ex presidente Néstor Kirchner. Mucho de lo que señalamos sobre el MUP se repite en el discurso identitario que presenta esta organización. La matriz nacional-popular se observa en la concepción de un Estado que puede y debe ser utilizado como herramienta política para orientar la economía hacia una distribución equitativa de la riqueza, promoviendo la industria nacional y el mercado interno, además de velar por los intereses de los más desprotegidos, los sectores sociales de menores ingresos. De igual modo se resalta la importancia de profundizar el proceso de integración regional que se viene desarrollando en los últimos años, uno de los logros que más se le destaca a la gestión kirchnerista.

En la misma lógica se señalan las contradicciones del mundo de la política, la complejidad de los actores, la infinidad de intereses en juego y la necesidad de establecer alianzas con sectores políticos que de otro modo jugarían fuertemente en contra de las medidas mejor direccionadas del gobierno. Entre las distinciones sobre las que se insiste y que son desatendidas por otros discursos, está la diferenciación del Frente Para la Victoria respecto del Partido Justicialista. En efecto, mientras que para muchas organizaciones esta diferenciación carece de sentido o relevancia, tanto para MBP-LS como para el MUP, se trata de una distinción fundamental que refiere a un intento de ir construyendo una nueva alternativa política en oposición a los sectores identificados con la derecha ideológica y política que moran al interior del peronismo. Por último se hace especial mención de las dificultades de la gestión pública, dando cuenta de las múltiples contradicciones y niveles al interior de una estructura administrativa tan vasta y compleja, además de los variados y poderosos actores que operan en contra de la intervención del Estado y las políticas redistributivas.

En cuanto a los puntos distintivos del discurso de la organización, observamos un nivel de crítica mayor respecto al kirchnerismo -sus principales aliados políticosque el que presenta el MUP. Esto permite pensar en un tipo de cierre o sutura en lo

\footnotetext{
$\overline{107}$ Nos referimos al cuadro del apartado 3.9. en donde identificamos "exclusión de subgrupos", inferioridad en el "status del otro" y juicios ético morales de desacreditación.
} 
político que no deja de ser contingente y precario, contemplando en todo momento la posibilidad real y concreta de dejar de sostener la articulación política -de baja intensidad- con el kirchnerismo. En este sentido aparecen diversas menciones que muestran que la adhesión al kirchnerismo está sujeta al eventual rumbo que adopte dicho proceso político, al peso que adquiera el "andarivel izquierdo" dentro de ese conglomerado de fuerzas, como así también las alianzas "por derecha". De la misma manera se señala que se marcha hacia la conformación de un espacio nacional popular menos heterogéneo que el que constituye el kirchnerismo, espacio que tendrá mayor o menor relación con el kirchnerismo dependiendo del rumbo que tomen los acontecimientos. De este modo el tipo de sutura que propone la organización se mantiene en un nivel precario que pareciera permitirle, al mismo tiempo, proteger su cuerpo identitario y mantener mayores posibilidades de articulación subvirtiendo el esquema binario kirchnerismo vs. anti-kirchnerismo.

\section{FPDS, principios organizativos y autonomía}

EL FPDS es una organización que presenta bastantes puntos de desencuentro con las que venimos observando hasta aquí. Se trata de un tipo organización que recoge algunas críticas que se vienen sucediendo y acumulando en el derrotero de la izquierda que tiene que ver con tratar de superar ciertos esquemas teóricos señalados como ineficaces. En este sentido aparecen fuertes críticas a los posicionamientos de lo que llaman la izquierda tradicional y de la izquierda nacional-popular, en una búsqueda que intenta superar viejos planteos y formas de organización. Es en esta dirección que se critica, justamente, la rigidez de determinados modelos teóricoideológicos y sus respectivos lineamientos políticos.

Siguiendo nuestro esquema de análisis, el FPDS se presenta como una organización que busca romper con ciertas fijaciones de sentido y esquemas de análisis rígidos, como por ejemplo superando la concepción obrero-céntrica de sujeto político y el propio modelo dicotómico marxista. Se presentan como una organización que lucha por un objetivo último que es el socialismo, pero el cual no tiene demasiadas definiciones previas, sino que está sujeto al tipo de construcción y de significado que los propios actores que lo construyen le den. Se observa un claro distanciamiento respecto a otros discursos y un vaciamiento de significado de un significante tan relevante como lo es el de socialismo.

Los puntos que configuran su identidad política se orientan más en un nivel organizativo, en métodos de construcción. Así definen una serie de principios organizativos que establecen los límites de su identidad política y que se resumen en: democracia de base, formación, lucha y autogestión. Así se busca mantener flexible y 
abierto el esquema de construcción política respecto a los pasos, medidas, posibles aliados y orientaciones políticas que asumirá la organización. Es decir, no se plantean como cuestiones necesarias la adopción de un camino insurreccional, el establecimiento de una dictadura del proletariado, la socialización de los medios de producción, o la destrucción del Estado, etc. En vez de eso, se establecen determinados principios organizativos dentro de los cuales se deberá ir avanzando en la construcción de poder popular, "que no es ni más ni menos que el hecho de ir generando niveles organizativos cada vez más altos a nivel de los sectores populares".

Al escapar de ciertos esquemas rígidos y determinantes, el FPDS se posiciona en el escenario político desde una concepción que destaca ciertas contradicciones que están ausentes en otros discursos. Desde una clara oposición al kirchnerismo, el FPDS no deja de reconocer ciertas complejidades de la política, (como la ya mencionada idea de que "en la política no hay lugares vacíos"), rescatando algunos puntos y diferencias del actual gobierno y sus aliados respecto a gobiernos anteriores. Es decir no opera una lógica dicotómica que homologa a toda la clase política y no establece diferencia alguna entre una fuerza y otra. EI FPDS logra desarrollar algunos diagnósticos según los cuales el posicionamiento respecto a un actor -en este caso su oposición al kirchnerismo- no lo conduce a negar determinadas diferenciaciones o puntos favorables (por ejemplo se habla de la disminución de la variable represiva y de que no es lo mismo para el escenario latinoamericano que esté Kirchner a que esté alguien "de derecha").

Pese a renegar de la etiqueta de autonomistas que otros discursos le imprimen, la cuestión de la autonomía posee una centralidad significativa en la identidad política de la organización. Si bien se aclara en diversas intervenciones que la organización no defiende una postura de autonomía extrema, claramente inviable y contraproducente desde el punto de vista político, sí se destaca la importancia de mantener distancia de determinadas estructuras políticas e institucionales con el objetivo de respetar sus principios organizativos y resguardar así sus lineamientos identitarios fundamentales. Si bien es claro que se alejan de la caricaturización autonomista que suelen endilgarle, sí insisten en definirse "como autónomos del Estado, los partidos, las Iglesias y las Centrales sindicales". Consideramos que esta definición puede conducir, en coyunturas políticas específicas, a determinadas concepciones que obstaculicen procesos positivos de articulación política de alta intensidad. Entendemos que los diferentes y múltiples espacios que se abren en el discurso de la organización al juego político y que facilitan procesos de articulación mediante la operación de significantes vacíos y flotantes, pueden encontrar un tipo de cierre en la idea de autonomía si ésta termina sobredeterminando a los diferentes elementos que componen el discurso. 


\section{MTD-Aníbal Verón, crítica a la razón dogmática}

Todo el relato de Juan Cruz Daffunchio está atravesado por una fuerte crítica hacia lo que califica como el dogmatismo de la izquierda. Desde esta perspectiva se ataca a lo que se considera la ortodoxia de la izquierda, la que es interpelada en función de su efectividad política. En la misma línea de lo que venimos planteando se critican las rígidas fijaciones de sentido que pueblan el discurso identitario de la mayoría de las formaciones políticas del campo popular, que se identifican como obstáculos a procesos de articulación.

Una gráfica apreciación de esto lo constituye la mención de Daffunchio de lo común que resulta entre las formaciones de izquierda "dividirse hoy por lo que vas a hacer dentro de 20 años". De este modo, se ponen en discusión los debates sobre la necesariedad de la "dictadura del proletariado", "la destrucción del Estado", etc., los que son vistos como abstractos y que terminan postergando las discusiones sobre las dificultades que el campo popular tiene para la construcción de procesos políticos con poder real. Desde esta perspectiva es que se menciona al PCR como la formación política de la que se sienten más cercanos, que se corresponde con la manifiesta propensión hacia la articulación que presenta dicho partido. Como ya dijimos, creemos que tal propensión se limita a niveles más bien tácticos e instrumentales, en tanto en su discurso identitario observamos múltiples fijaciones plenas de sentido que interpretamos como obstáculos para la profundización de procesos de articulación de alta intensidad.

Una cuestión interesante que resaltamos de este discurso es que se trata de un protagonista que fue viviendo en su propia experiencia el abandono de determinados dogmas a lo largo de su carrera política. Así se destacan cambios en sus concepciones sobre diversos tópicos (la concepción de Estado, la insurrección, el peronismo, etc.) los cuales comparten el hecho de ir rompiendo con determinadas verdades muy afianzadas en los discursos marxistas-leninistas. Una cuestión muy ilustrativa la constituye su concepción sobre el Estado, que pasó de verlo como una extensión del poder de la burguesía -lo que hacía necesaria e inevitable su destrucción- a verlo como un espacio de poder disputable y utilizable a favor de los sectores dominados. Lo que resulta interesante del planteo de Daffunchio es que su cambio obedeció a la observación de las experiencias de Venezuela y Bolivia, lo que lo llevó a repensar algunos de los supuestos que ordenaban su pensamiento político. Es decir la teoría se adecuó a la experiencia y no al revés... Nos parece relevante este ejemplo porque ilustra la crítica a los dogmatismos y a las fijaciones plenas de sentido, 
que se interpretan, desde aquí, como perjudiciales para la articulación y la eficacia política del campo popular.

Desde esta perspectiva se llega a lecturas sobre la realidad política nacional y latinoamericana que incluyen un mayor nivel de diferenciación y complejización que en otros discursos. Así se resaltan contradicciones y bemoles que, desde nuestro punto vista, enriquecen el análisis político respecto a visiones más esquemáticas. Por ejemplo, el kirchnerismo es atacado por diversos flancos, pero no se dejan de reconocer ciertas virtudes, más a la luz de lo que se vislumbra como alternativa real al actual gobierno. También se reconocen las contradicciones al interior del Estado, las limitaciones del gobierno en su control, etc.

En definitiva se trata de un discurso que centra su preocupación en las limitaciones políticas del campo popular y en la necesidad de privilegiar articulaciones políticas profundas que posibiliten la construcción de un poder político real. Para esto se reclama que tanto las organizaciones de orientación marxista-leninista, como las nacional-populares -más las primeras que las segundas- abandonen las posiciones dogmáticas y subordinen sus preconcepciones a la construcción de poder político. En líneas generales, el planteo de Daffunchio coincide con la orientación de nuestro punto de vista acerca de las dificultades que se derivan de las fijaciones plenas de sentido para las posibilidades de profundizar procesos de articulación política.

\subsection{Palabras finales}

Como señalábamos al principio, este trabajo no busca dar respuestas acabadas sobre el problema de la articulación política en el campo popular. Sabemos que son múltiples y variados los elementos que inciden en este fenómeno y que a su vez derivan de órdenes o dimensiones muy disímiles: desde rivalidades personales de los dirigentes, hasta "operaciones" malintencionadas de rivales o enemigos políticos, se podrá encontrar un numeroso abanico de variables que resultan relevantes para la comprensión de las modalidades que adquiere la articulación política en el campo popular. Las pretensiones de este trabajo son concretamente las de avanzar en una caracterización de los elementos políticos e ideológicos que estructuran los discursos identitarios de las distintas organizaciones, analizando desde allí sus posibles implicancias en relación a la articulación política.

Lo que pudimos recoger a lo largo de la investigación es la existencia de múltiples dimensiones en torno de las cuales se estructuran los elementos políticoideológicos que configuran los discursos identitarios de las distintas organizaciones. Las diferencias y la rigidez con las que se establecen tales elementos, nos parece que constituye un tema relevante para comprender las modalidades que adquiere la 
articulación política. De este modo podemos observar en torno de qué tópicos se establecen las fijaciones de sentido que reducen los espacios para el entendimiento cuando se plantean diferencias. Intentaremos sintetizar lo visto hasta aquí en el siguiente cuadro:

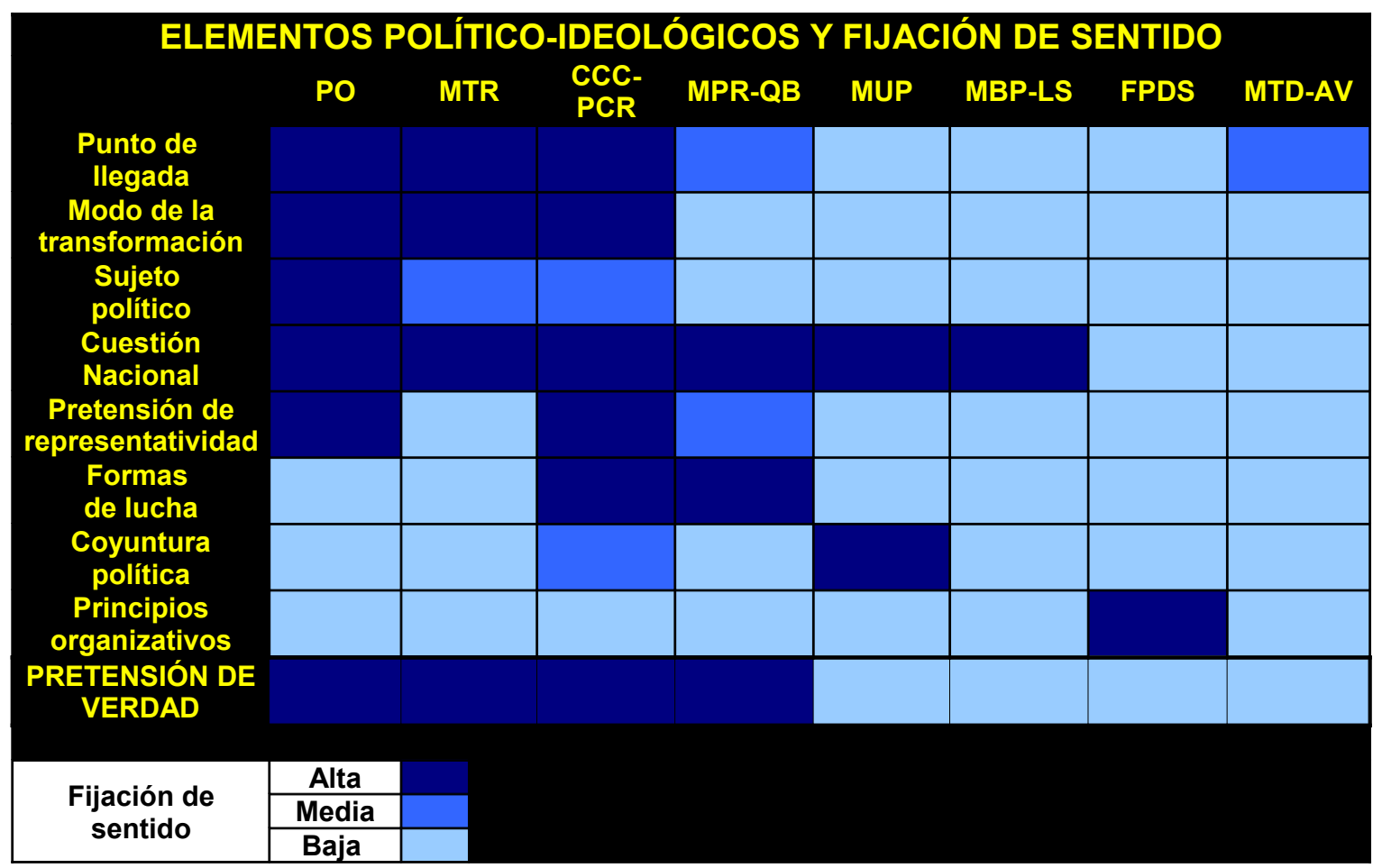

Nos parece interesante poder cotejar las distintas fijaciones de sentido con las que las organizaciones estructuran sus discursos identitarios, más allá de las diferencias de la orientación del contenido de cada posicionamiento. Los casilleros más oscuros indican las dimensiones en las que las distintas organizaciones establecen sus fijaciones de sentido más altas. De este modo podemos identificar qué papel juegan las distintos elementos político-ideológicos en la posibilidad de ampliar las condiciones para el diálogo y el entendimiento entre posiciones que se perciben como divergentes.

El Punto de llegada se refiere al tipo de sociedad que se proyecta como objetivo final, donde evaluamos cuan definido/preestablecido aparece el objetivo político último de la labor de transformación. El Modo de la transformación remite especialmente a la disyuntiva entre revolución y reforma que incluye un posicionamiento sobre la naturaleza y el rol que debe asignársele al Estado en tal proceso. La dimensión del Sujeto político hace referencia a la relación entre el partido y la clase, a la rigidez con la que se presenta tal relación y la especificidad con la que. se define el sujeto político que debe ser interpelado. La Cuestión nacional se vincula con el debate, de gran presencia a lo largo de todo el trabajo, de enmarcar o no a la 
cuestión de clase dentro de los lineamientos de independencia económica y soberanía. política. La Pretensión de representatividad es el rol que se adjudica cada organización como centro o referencia privilegiada del conjunto de las luchas del campo popular. Las Formas de lucha hace alusión a la centralidad (que puede plantearse en términos de necesariedad) que adquiere determinada forma de enfrentamiento en la disputa política. La dimensión sobre la Coyuntura política se refiere al peso que adquiere un posicionamiento político coyuntural en la capacidad de sobredeterminar otras dimensiones. Los Principios organizativos hacen referencia a los lineamientos que rigen en los mecanismos de construcción organizacional (en este caso puntual, la cuestión de la autonomía resulta el punto sobresaliente). Finalmente. incluimos el eje de la Pretensión de verdad que observamos en cada discurso, eje que sobrevuela cada uno de los elementos político-ideológicos que comparamos aquí, y que analiza -en última instancia- el espacio que cada discurso abre para poner en discusión el conjunto de sus posicionamientos y definiciones.

Como se desprende del cuadro, entendemos que pueden identificarse distintas dimensiones al interior de cada discurso identitario que resultan relevantes para pensar el problema de la articulación política en el campo popular. Mientras que para algunas organizaciones determinada forma de lucha resulta innegociable, para otras lo será la forma que deberá adquirir el proceso de transformación, el mantenimiento estricto de la independencia de clase o la cuestión nacional. En todos los casos se trata de fijaciones de sentido que amplían o reducen el espacio para avanzar en el entendimiento entre las distintas organizaciones $y$, por tanto, en promover mejores condiciones para la articulación política de alta intensidad. Las distintas fijaciones de sentido, a su vez, pueden estar apoyadas en pretensiones de verdad que refuerzan su rigidez.

El Punto de llegada se refiere al tipo de sociedad que se proyecta comoobjetivo político último, donde evaluamos cuan definido resulta el objetivo último de la tabor de transformación. El Modo de la transformación se refiere concretamente a la disyuntiva entre revolución y reforma que incluye un posicionamiento sobre la naturaleza y el rol que debe asignársele al Estado. La dimensión del-Sujeto político hace referencia a la relación entre el partido y la clase; a la rigidez con la que sepresenta tal relación. La Guestión nacional se refiere al debate entre enmarcar o no a la cuestión de clase dentro de los lineamientos de independencia económica y soberanía política. La Pretensión de representatividad es el rol que se adjudica cada organización como centro o referencia privilegiada del conjunto de las luchas det eampo popular. Las Formas de lucha hace alusión a la centralidad (que puede- 
plantearse en términos de necesariedad) que adquiere determinada forma deenfrentamiento en la disputa política. La dimensión sobre la Goyuntura política serefiere al peso que adquiere un posicionamiento político coyuntural en la capacidad de sobredeterminar otras dimensiones. Los Principios organizativos hacen referencia a los lineamientos que rigen en los mecanismos de construcción organizacional (en este easo puntual, la cuestión de la autonomía resulta el punto sobresaliente). Finalmente, incluimos el eje de la PRETENSIÓN DE VERDAD que observamos en cada discurso, eje que sobrevuela cada una de las definiciones y elementos político-ideológicos que comparamos aquí.

Como se desprende del cuadro, entendemos que pueden identificarse distintas dimensiones al interior del discurso identitario que resultan relevantes para pensar ef problema de la articulación política en el campo popular. Mientras que para algunasorganizaciones determinada forma de lucha resulta innegociable, para otras lo será la forma que deberá adquirir el proceso de transformación, el mantenimiento estricto de la independencia de clase o la cuestión nacional. En todos los casos se trata defijaciones de sentido que amplian o reducen el espacio para avanzar en et entendimiento entre las distintas organizaciones y, por tanto, en promover mejorescondiciones para la articulación política de alta intensidad.

Por lo visto hasta aquí, consideramos que los discursos identitarios que se construyen alrededor de la matriz marxista-leninista poseenincluyen mayor cantidad de una serie de elementos que dificultan el desarrollo de procesos de articulación política. Se trata de fijaciones de sentido plenas presentes en varios de sus posicionamientos político-ideológicos que reducen la posibilidad de desarrollar lógicas equivalenciales -a partir del uso de significantes vacíos- que faciliten la articulación. Creemos que esto es así en tanto operan lógicas esencialistas que derivan en concepciones de lo político en las que dicha dimensión aparece fuertemente subordinada a elementos económicos que suprimen la especificidad y complejidad de la dimensión política. La dicotomización del espacio político -a partir de la traslación de la contradicción estructural burguesía-proletariado-, combinada con la rigidez y predeterminación con la que se establecen los principales rasgos del proceso de transformación que se pretende desarrollar, parecen potenciar las dificultades de avanzar en procesos de articulación. Esto a su vez se corresponde con una alta pretensión de verdad, que opera principalmente mediante la apelación a cierta verdad científica que desestima tanto la multiplicidad de aspectos presentes en todo análisis del universo social, como las posibles y variadas lecturas e interpretaciones que surgen de él.

Por fuera de la matriz marxista-leninista, aparecen discursos identitarios que ofrecen un mayor espacio al desarrollo de lógicas equivalenciales a partir de suturas y 
fijaciones de sentido parciales, en las que la contingencia adquiere una centralidad mayor, y por tanto, un mayor campo para las operaciones políticas. El tipo de cierre de lo social contempla contradicciones y diferenciaciones ausentes en otros discursos, lo que facilita pensar el escenario de lo político en términos más graduales, identificando con mayor nivel de detalle acercamientos y distancias, lo que puede derivar en mejores posibilidades para la articulación política. Esto no quita que se pueda caer en posicionamientos políticos plenamente fijados que, a partir de la aceptación del carácter contradictorio del universo social y político, impida registrar las similitudes ideológico-políticas más allá de coyunturas específicas_por causa de la sobredeterminación de la dimensión correspondiente a la coyuntura política.--Del mismo modo, el tipo de fijación de sentido en torno a los principios organizativos -especialmente del significante de autonomía- también aparece como una variable relevante para pensar las posibilidades de articulación política en algunas de estas organizaciones.

Del mismo modo, el tipo de fijación de sentido en torno del significante deautonomía también aparece como una variable relevante para pensar las posibilidades de articulación política en algunas de estas organizaciones.

En definitiva, y más allá de la multiplicidad de variables que inciden en las modalidades que adquiere la articulación política, se pueden distinguir entre las organizaciones del campo popular una serie de debates ausentes en organizaciones pertenecientes a otros espacios político-ideológicos. Más aún, identificamos en los discursos identitarios explorados, la presencia de tópicos en torno de los cuales se establecen posturas que devienen en diferencias insalvables, en donde ya no se trata de debates, sino más bien del choque entre posicionamientos preestablecidos que invalidan de antemano la posibilidad de avanzar en consensos. El tipo de sutura que se hace para aprehender y explicar lo social pareciera ocupar un lugar relevante en la raíz de tales posicionamientos. El modo en que se define lo económico, lo político y la relación entre ambas dimensiones de lo social, delimitan los espacios de lo necesario y de lo contingente. Las fijaciones de sentido resultantes posibilitan mayores o menores oportunidades para el desarrollo de lógicas equivalenciales lo que, creemos, se vincula con las posibilidades de avanzar en procesos de articulación política.

A lo largo de este trabajo hemos podido comparar los principales rasgos de los discursos identitarios de una serie de organizaciones que consideramos representativas de lo que llamamos el campo popular. En las sucesivas comparaciones dimos cuenta de los distintos posicionamientos, sus semejanzas y diferencias. Del mismo modo -y quizás como saldo más relevante para nuestro análisis- pudimos identificar los debates posibles, lo que está en discusión y lo que no, 
lo que es posible consensuar y lo que aparece clausurado de antemano. Consideramos que lo visto hasta aquí resulta útil para avanzar en la discusión sobre la articulación política del campo popular. Será un nuevo desafío la profundización de lo analizado hasta aquí, pero eso ya formará parte de otro trabajo. 


\section{BIBLIOGRAFÍA}

- Aboy Carlés, Gerardo (2001), Las dos fronteras de la democracia argentina. La reformulación de las identidades políticas de Alfonsín a Menem, Homo Sapiens Ediciones, Rosario, Argentina,

- (2005), "Identidad y diferencia política", en Schuster F.; Naishtat F.; Nardacchione G. y Pereyra S. (comps.): Tomar la palabra: Estudios sobre protesta social y acción colectiva en Argentina contemporánea, Prometeo, Bs. As. pp. 111-128.

- Alexander, Jeffrey C. (1989), Las teorías sociológicas desde la Segunda Guerra Mundial, Barcelona, Editorial Gedisa,.

- Almeyra, Guillermo (2004) La protesta social en Argentina (1990-2004). Buenos Aires, Peña Lillo-Ediciones Continente.

- Altamirano, Carlos (2001), Peronismo y cultura de izquierda. Bs. As., Temas Grupo Editorial.

- Arditi, Benjamín (2007), "Post-hegemonía: la política fuera del paradigma postmarxista habitual", Mimeo. http://arditi.googlepages.com/ArditiPosthegemoniacarta.doc

- Armelino, Martín (2004), "Algunas diferencias al interior del campo popular: la experiencia reciente de la CTA y la FTV." Informe final del concurso: Poder y nuevas experiencias democráticas en América Latina y el Caribe. Programa Regional de Becas CLACSO. Dirección URL:

http://bibliotecavirtual.clacso.org.ar/ar/libros/becas/2003/poder/armelino.pdf

- Auyero, Javier (2002), La Protesta. Retratos de Beligerancia Popular en la Argentina democrática, Buenos Aires, Libros del Rojas (UBA).

- (2000), "Los estallidos en provincia: globalización y conflictos locales", en Revista Punto de Vista N67, Agosto de 2000.

- Bidaseca, Karina (2004) "Vivir bajo dos pieles: En torno a la resignificación de las políticas sociales y las complejidades dl vínculo con el estado. El Movimiento de Trabajadores de Solano. Informe final", CLASPO-IDES. Disponible en http://lanic.utexas.edu/project/etext/lilas/claspo/rtc/

- Borón, Atilio (2000), Tras el Búho de Minerva. Mercado contra democracia en el capitalismo de fin siglo, FCE, Buenos Aires. (Disponible en http://bibliotecavirtual.clacso.org.ar/

- Capdevilla, Néstor, 2006, El concepto de ideología, Nueva Visión, Buenos Aires. 
- Casas, Aldo (2004), "Después de la rebelión de diciembre del 2001. Elementos de interpretación y balance de la lucha de clases en Argentina", Revista Herramienta (versión digital). Dirección URL:

http://www.herramienta.com.ar/modules.php?

op $=$ modload $\&$ name $=$ News $\&$ file $=$ article $\&$ sid $=305$

- CELS (2003), El Estado frente a la protesta social 1996-2002, Buenos Aires, Siglo XXI.

- Colectivo Situaciones (2002), 19 y 20. Apuntes para el nuevo protagonismo social. Buenos Aires, Ediciones De mano en mano.

- (2001) Cuadernos Nro. 4. MTD Solano, Buenos Aires, Ediciones De mano en mano.

- Cotarelo, María Celia (2002), “Un punto de inflexión en las luchas populares en la Argentina actual: la insurrección espontánea de diciembre de 2001", en Revista Herramienta, №19.

- (2000), "La protesta en la Argentina de los '90", en Revista Herramienta $\mathrm{N}^{\circ} 12$, Otoño 2000, pp.79-90.

- D’Amico, Victoria y Pinedo, Jerónimo (2008), "Trabajar desde lo social y rescatarse: diferentes construcciones de sentido acerca de la participación en una organización local", publicado en el CD de las "V Jornadas de Sociología de FACHE-UNLP", La Plata.

- Delamata, Gabriela (2004), Los barrios desbordados. Las organizaciones de desocupados del Gran Buenos Aires, Buenos Aires, Libros del Rojas (UBA).

- (2005), "Las organizaciones de desocupados en el Gran Buenos Aires y la(s) crisis", en Schuster F.; Naishtat F.; Nardacchione G. y Pereyra S. (comps.): Tomar la palabra: Estudios sobre protesta social y acción colectiva en Argentina contemporánea, Bs. As., Prometeo, pp. 365-385.

- Delamata, Gabriela y Armesto, Melchor (2005), "Construyendo pluralismo territorial. Las organizaciones de desocupados del gran buenos Aires en la perspectiva de sus bases sociales". En, Delamata, G. (compiladora); Armesto, M.; Gurrera, M.S.; Koehs, J.; Schillagi, Ciudadanía y Territorio - Las Relaciones políticas de las nuevas identidades sociales, Bs. As., UNSAM Edita.

- Delfini, Marcelo y Picchetti, Valentina (2004) "De la fábrica al barrio y del barrio a las calles. Desempleo y construcción de identidades en los sectores populares desocupados del conurbano bonaerense". En: Battistini, O. (comp.) El trabajo frente al espejo. Continuidades y rupturas en los procesos de 
construcción identitaria de los trabajadores. p. 269-290. Buenos Aires: Prometeo.

- Delgado Parra, Ma. Concepción (2001) "El criterio amigo-enemigo en Carl Schmitt. El concepto de lo político como una noción ubicua y desterritorializada", en Revista Cuaderno de Materiales Filosofía y Ciencias Humanas, №14 Marzo-mayo 2001. Versión electrónica: www.filosofia.net/materiales

- Dinerstein, Ana. (2001) "El poder de los irrealizado. El corte de ruta en Argentina y el potencial ¿subversivo de la mundialización”. En Revista OSAL, n. 5 P. 11-16. Buenos Aires, 2001.

- Di Tella, Torcuato (2004), Coaliciones Políticas. ¿Existen derechas e izquierdas?, Capital Intelectual, Bs. As.

- (2003), Actores y coaliciones. Elementos para una teoría de la acción política, La Crujía, Bs. As.

- Favaro, Orietta y otros (1997), "La conflictividad social en Neuquén”, en Revista Realidad Económica, №148.

- Ferraudi Curto, María Cecilia (2006) "Lucha" y "Papeles": "Mientras tanto: Política y modo de vida en una organización piquetera", Tesis de Maestría, Maestría en Antropología Social, IDAES/IDES, Buenos Aires.

- Forni, Floreal (2002), De la exclusión a la organización. Hacia la integración de los pobres en los nuevos barrios del conurbano bonaerense, Buenos Aires, Ediciones Ciccus.

- Galasso, Norberto (2007), Aportes críticos a la historia de la izquierda argentina. Tomo I, Nuevos Tiempos, Buenos Aires.

- Gómez, Elizabeth y Federico Kindgard (1998) "Los cortes de ruta en la provincia de Jujuy. Mayo/Junio de 1997." En Revista PIMSA N², pp. 149-194.

- Gómez, Marcelo (2007), "Origen y desarrollo de los patrones de acción y organización colectiva desafiante de los movimientos de desocupados en la Argentina", en Villanueva, Ernesto y Massetti, Astor (comp) (2007), Movimientos sociales y acción colectiva en la Argentina de hoy., Buenos Aires, Prometeo.

- Hobsbawm, Eric (1971), Las revoluciones burguesas, Editorial Guadamarra.

- Iñigo Carrera, Nicolás y Maria Cecilia Cotarelo (1998), "Los llamados "cortes de ruta". Argentina 1993-97." En Revista PIMSA 2, pp.141-147. 
- Klachko, Paula (2005) "Objetivos de la protesta de cinco organizaciones de desocupados. Primer semestre 2002 - Primer semestre 2004", en Revista PIMSA N55, pp. 160-197.

- Laclau, Ernesto (2005), La razón populista, Fondo de Cultura Económica, Buenos Aires.

- (1996), Emancipación y diferencia, Ariel, Buenos Aires.

- (2003), "Identidad y hegemonía: el rol de la universalidad en la construcción de lógicas políticas" en Laclau, Zizek y Butler Contingencia, hegemonía y universalidad. Bs. As., Fondo de Cultura Económica, pp. 49-94.

- (2002), Misticismo y retórica política, Bs. As., Fondo de Cultura Económica.

- (2000), Nuevas reflexiones sobre la revolución en nuestro tiempo, Bs. As., Nueva Visión.

- (2006), "Por qué construir un pueblo es la tarea principal de la política radical" en Cuadernos del CENDES, mayo-agosto año/vol 23, nùm., 062, políticas públicas. pp. 1-36. http://www.cendesucv.edu.ve/pdfs/revista62/cap1.pdf

- Laclau, Ernesto y Mouffe, Chantal ([1985] 2006), Hegemonía y estrategia socialista. Hacia una radicalización de la democracia, Bs. As., Fondo de Cultura Económica.

- Laufer, Rubén y Spiguel, Claudio (1999), "Las puebladas argentinas a partir del santiagueñazo de 1993. Tradición histórica y nuevas formas de lucha". En: López Maya, Margarita, ed., Lucha popular, democracia, neoliberalismo: protesta popular en América Latina en los años de ajuste. Caracas, Nueva Sociedad.

- Lenguita, Paula (2002), "Los desafíos teóricos de la identidad piquetero", Publicación electrónica. CEIL-PIETTE. Buenos Aires, Disponible en http://www.insumisos.com/httpdocs/articulos/identidad\%20de\%20los \%20piqueteros.pdf

- Maceira, Verónica y Spaltenberg, Ricardo (2001), "Una aproximación al movimiento de desocupados en el marco de las transformaciones de la clase obrera en la Argentina", en Revista OSAL, n. 5 pp. 23-28. Buenos Aires, 2001.

- Maneiro, María (2007), De encuentros y desencuentros. Estado y movimientos de trabajadores desocupados del Gran Buenos Aires (1996-2005), Río de Janeiro, Instituto Universitario de Pesquisas do Río de Janeiro. 
- Massetti, Astor (2007), "Piqueteros o la política como voluntad de representación" en Villanueva, Ernesto y Massetti, Astor (comp) (2007), Movimientos sociales y acción colectiva en la Argentina de hoy. Buenos Aires, Prometeo.

- Mayntz, Holm y Hubner ([1975]1996), Introducción a los métodos de la sociología empírica, Madrid, Alianza Universidad.

- Merklen, Denis (2005), Pobres ciudadanos. Las clases populares en la era democrática (1983-2003), Buenos Aires, Gorla.

- Mires, Fernando (1988), La rebelión permanente. La revoluciones sociales en América Latina, México, Siglo Veintiuno Editores.

- Moreno, José E. (2002) "Las organizaciones de desocupados como actores centrales de la protesta en Argentina. Un estudio de caso: la CTA de San Francisco Solano" (Tesina de Licenciatura), disponible en Trabajos Finales. Licenciatura en Sociología (1985-2003). Vol 1.

- (2008), “¿Podemos militar juntos? Articulación y fragmentación política del campo popular argentino. Una mirada a organizaciones del movimiento piquetero", ponencia publicada en el CD de las II Jornadas de Estudios Políticos. La política en la Argentina actual: nuevas formas de pensar viejos problemas. 12 y 13 de noviembre 2008. Universidad Nacional de General Sarmiento.

- (2008), "Lógicas y contenidos ideológicos en la articulación del movimiento piquetero", ponencia publicada en el CD de las $V$ Jornadas de Sociología de la UNLP, La Plata, 10, 11 y 12 de diciembre de 2008, Universidad Nacional de La Plata.

- (2009), “¿Lo tomo, lo dejo, lo uso o lo rompo? Concepciones sobre el Estado y estrategias políticas entre las organizaciones del campo popular.", ponencia publicada en el CD del / Congreso Nacional: "Protesta Social, Acción Colectiva y Movimientos Sociales, 30 y 31 de Marzo de 2009, (ISBN 978-987-24976-2-0), Universidad de Buenos Aires

- Mouffe, Chantal (2007) En torno a lo político, Bs. As., Fondo de Cultura Económica.

- Muñoz, M. Antonia (2006), "Laclau y Rancière: algunas coordenadas para la lectura de lo político" en Andamios. Revista de Investigación social. Pp.119-144. 
- Muñoz, M. Antonia y Retamozo, Martín (2008), "Hegemonía y Discurso en la Argentina contemporánea. Efectos políticos de los usos de "pueblo" en la retórica de Néstor Kirchner" en Revista Perfiles Latinoamericanos, Núm. 31, México. Pp. 121-149.

- Nisbet, Robert (1969), La formación del pensamiento sociológico I, Amorrotu. Parra, Alejandra (2008), "Articulación y Hegemonía. La tensión entre lo situacional concreto de cada experiencia de lucha y lo general abstracto de la construcción colectiva." En Revista Atenea Digital, № 13, pp.27-48.

- Papua, Jorge (1970), Técnicas de investigación aplicadas a las ciencias sociales, México, FCE.

- Pereyra, Carlos (1988), "Gramsci: estado y sociedad civil", en Revista Zona Abierta $\mathrm{N}^{\circ} 48 / 49$.

- Pereyra, Sebastián (2002), "Transformaciones de la protesta social en Argentina", en Giarracca, N. y otros, Protesta Social en Argentina. Transformaciones económicas y crisis social en el interior del país, Buenos Aires, Alianza. (en coautoría).

- Petras, James y Veltmeyer, Henry (2005), Movimientos sociales y poder estatal. Argentina, Brasil, Bolivia, Ecuador, México, Editorial Lumen México.

- Pucciarelli, (2002), "Una asignatura pendiente", en Revista Argumentos, №1, diciembre 2002.

- Ramos Rollón, M. Luisa (1997), "La dimensión política de los movimientos sociales: algunos problemas. conceptuales" en REIS, nº 79, pp.247-263.

http://www.reis.cis.es/REISWeb/PDF/REIS_079_11.pdf

- Retamozo, Martín (2006), "Populismo y teoría política: de una teoría hacia una epistemología del populismo para América Latina" en Revista Venezolana de Economía y Ciencias Sociales [en línea]. Disponible en: <http://redalyc.uaemex.mx/redalyc/src/inicio/ArtPdfRed.jsp?iCve=17712204.

- 2008, "Entre lo político y la política: sujetos políticos, conformación y disputa por el orden social", Mimeo.

- Rofman, Adriana (comp) (2002) La acción de las organizaciones sociales de base territorial, Buenos Aires, Ediciones de la Universidad Nacional de Gral. Sarmiento.

- Saur, Daniel Guillermo, (2006) "Reflexiones metodológicas: Tres dimensiones recomendables para la investigación sobre discursos sociales", en Jiménez García, Marco Antonio (coord.) Los usos de la teoría en la investigación, México, Ed. Plaza y Valdes. 
- Scribano, Adrián (1999), "Argentina cortada: cortes de ruta y visibilidad social". En: López Maya, Margarita, ed., Lucha popular, democracia, neoliberalismo: protesta popular en América Latina en los años de ajuste. Caracas, Nueva Sociedad.

- Shinzato, Federico y Zanzioth, Norberto (2007), Las izquierdas en la política argentina. Las izquierdas sientan posición sobre los principales aspectos de la política y la economía en la Argentina y el mundo, Bs. As., Divino Tesoro.

- Soage, Ana (2006), "La teoría del discurso de la Escuela de Essex. en su contexto teórico", CÍRCULO de Lingüística Aplicada a la Comunicación (clac) nro 25, 45-61, Universidad Complutense de Madrid. ISSN 1576-4737. http://www.ucm.es/info/circulo/

- Svampa, Maristella y Pereyra, Sebastián (2003), Entre la ruta y el barrio, Bs. As., Editorial Biblos.

- (2005), "La política de los movimientos piqueteros", en Schuster F.; Naishtat F.; Nardacchione G. y Pereyra S. (comps.): Tomar la palabra: Estudios sobre protesta social y acción colectiva en Argentina contemporánea, Prometeo, Bs. As. pp. 343-364.

- Svampa, M, 2005, La sociedad excluyente, Taurus, Buenos Aires.

- 2006a, Argentina: Los Movimientos sociales e izquierdas, publicado en la revista ecuatoriana Entre voces, $n^{\circ} 5$, en enero de 2006. Versión digital http://www.maristellasvampa.net/archivos/ensayo11.pdf

- 2006b, Modelo de dominación, tradiciones ideológicas y figuras de militancia, Publicado en revista Pampa. Pensamiento/acción política, año1/nro1/julio 2006, Buenos Aires, Instituto de Estudios e Investigación, CTA. Versión digital: www.maristellasvampa.net/archivos/ ensayo15.pdf

- Tarrow, Sydney (1997), El poder en movimiento. Los nuevos movimientos sociales. La acción colectiva y la política, Madrid, Alianza.

- Tenti Fanfani, Emilio (2000), "Exclusión social y acción colectiva en la Argentina de hoy”, en Revista Punto de Vista N67, Agosto de 2000.

- Van Dijk, T. A. (2008), "Semántica del discurso e ideología" en Discurso \& Sociedad Vol 2 (1), pp.201-261, www.dissoc.org

- Villanueva, Ernesto y Massetti, Astor (comp) (2007), Movimientos sociales y acción colectiva en la Argentina de hoy., Buenos Aires, Prometeo. 
- Zeta, Sergio (2005), "A cuatro años de la rebelión argentina. Continuidades, rupturas y transformaciones". En Revista La Fogata Digital, dirección URL: http://www.lafogata.org/05arg/arg12/arg_29-1.htm

- Zizek, Slavoj, ([1994] 2003), Ideología. Un mapa de la cuestión, Fondo de Cultura Económica, Buenos Aires.

\section{Entrevistas realizadas por el autor para la investigación:}

- Néstor Pitrola, 2007 (Polo Obrero - Partido Obrero)

- Amancay Ardura, 2007 (Corriente Clasista y Combativa - Partido Comunista Revolucionario)

- Roberto Martino, 2007 (Movimiento Teresa Rodríguez)

- Fernando Esteche, 2007 (Movimiento Patriótico Revolucionario-Quebracho)

- Federico Martelli, 2007 (Movimiento de Unidad Popular)

- Roberto Baigorria, 2007 (Barrios de Pie - Libres del Sur)

- Martín Obregón, 2006 (Frente Popular Darío Santillán)

- Juan Cruz Daffunchio, 2007 (Movimiento de Trabajadores Desocupados "Aníbal Verón).

\section{Publicaciones gráficas y virtuales de las organizaciones}

- PCR, 2004, Programa del PCR de la Argentina. Dirección URL: http://www.pcr.org.ar/seccion.php?id_nota=486 http://www.pcr.org.ar/seccion.php?id_nota=489

- Revista Todo o Nada (MTR), Año 2, № 2 (abril de 2006).

- Movimiento de Unidad Popular, 2008. (página web de la organización). Dirección URL: http://www.mupargentina.com.ar

- Revista 2010 (MUP), No 8 y 14.

- FPDS, 2007, ¿Qué es el Frente Popular Darío Santillán?. Dirección URL: http://www.frentedariosantillan.org/1/index.php/a/2007/02/10/p385\#more385

- Libres del Sur (LS), 2008. (página web de la organización). Dirección URL: www.libresdelsur.org.ar .

- Movimiento Barrios de Pie (MBP). 2008. (página web de la organización). Dirección URL: www.barriosdepie.org.ar

- Oviedo, Luis (2001), Una historia del movimiento piquetero. De las primeras Coordinadoras a las Asambleas Nacionales, Bs. As., Ediciones Rumbos.

- Rubio, Leticia y Del Grosso, Leonardo (Comp.) (2005), Habla Quebracho. Una mirada histórica desde la resistencia, Bs. As., Chilavert. 


\section{Publicaciones periodísticas}

- Diario La Nación, 2007, "Política Nacional: Una izquierda fragmentada", Bs. As., 25/11/07, en Suplemento Enfoques. 